\title{
EVERTON RANDAL GAVINO
}

\section{PRODUÇÃO AUTOGESTIONÁRIA DE JANELAS E ADEQUAÇÃO SOCIOTÉCNICA.}

\section{Caso: Marcenaria Coletiva de Mulheres, assentamento rural Pirituba II, Itapeva/SP}

(versão corrigida - original disponível no Instituto de Arquitetura e Urbanismo / IAU)

\author{
Dissertação apresentada ao Instituto \\ de Arquitetura e Urbanismo da \\ Universidade de São Paulo para \\ obtenção do título de Mestre em \\ Arquitetura e Urbanismo \\ Área de Concentração: Arquitetura, \\ Urbanismo e Tecnologia \\ Orientadora: Prof. ${ }^{\text {a }}$ Assoc. ${ }^{\text {a }}$ Akemi Ino
}



GAVINO, E. R. Produção autogestionária de janelas e adequação sociotécnica. Caso: Marcenaria Coletiva de Mulheres, assentamento rural Pirituba II, Itapeva/SP. 144 f. Dissertação (Mestrado) Programa de Pós-graduação em Arquitetura e Urbanismo do Instituto de Arquitetura e Urbanismo, Universidade de São Paulo, São Carlos, 2013.

\section{FOLHA DE JULGAMENTO}

Candidato: Arquiteto e Urbanista Everton Randal Gavino

Título da dissertação: "Produção autogestionária de janelas e adequação sociotécnica. Caso: marcenaria Coletiva de Mulheres, Assentamento Rural Pirituba II, Itapeva-SP “

Data da defesa: $24 / 04 / 2013$.

Comissão Julgadora:

Profa. Associada Akemi Ino (orientadora) (Instituto de Arquitetura e Urbanismo - IAU/USP)
Resultado:

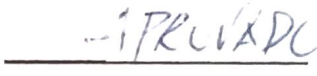

Profa. Dra. Adriana Maria Nolasco

(Escola Superior de Agricultura Luiz de Queiroz - ESALQ/USP)

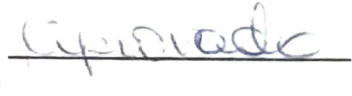

Profa. Dra. Ana Lucia Cortegoso

(Universidade Federal de São Carlos - UFSCar )

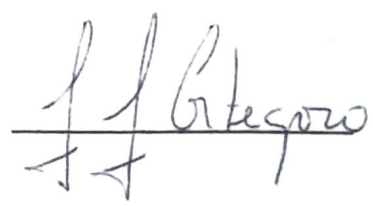

Presidente e Coordenador do Programa de Pós-Graduação em Arquitetura Urbanismo: Professor Titular Renato Luiz Sobral Anelli 
Dedico este trabalho à minha esposa e filha por tornarem possíveis as alegrias de se viver em família. À minha mãe. Ao meu pai pelo companheirismo. Aos meus irmãos que participaram de todos os momentos importantes da minha vida. A minha vó e avô pelos inúmeros esforços para que eu me formasse arquiteto. À minha nova mãe, Glória, por cuidar da minha família. Ao sogro, Seu Ademir, por se tornar mais um irmão. A bisa que me apresentou à minha querida. 



\section{Agradecimentos}

Aos vários orientadores e orientadoras que tive ao longo desta pesquisa Ana Lucia, Maria Zanin, Isabela, Maria Lucia, Ivan, Rosana, Luciana, Thaisa, Maurício, Leo, Diogo, Mari, Simone, Carol, Nina, André e outros tantos pesquisadores da incubadora e do HABIS. Aos meus professores, Akemi e Shimbo, que mais do que orientadores foram cúmplices de várias etapas importantes da minha vida. Aos jovens da marcenaria na figura de Giovane, Stefânia e Daniela que alavancaram novas conquistas apartir do trabalho com a madeira. À Cida, Dora, Beth, Bastiana e Cleide, essas meninas que tão cedo se tornaram mulheres, cujas trajetórias de vida como filhas, esposas, mães, trabalhadoras rurais e marceneiras refletem conquistas de cidadania e de visibilidade da força transformadora do trabalho coletivo.

Ao convênio Coordenação de Aperfeiçoamento de Pessoal de Nível Superior - Programa de Demanda Social - CAPES/DS por ter concedido bolsa de mestrado por dois anos.

Ao Instituto de Arquitetura e Urbanismo da USP pela oferta de condições adequadas para o cumprimento das etapas da pesquisa e da ação. 

"A leitura do mundo precede a leitura da palavra. Daí que a posterior leitura desta não pode prescindir da continuidade da leitura daquele."

Paulo Freire (In “A importância do Ato de Ler"), 1982. 



\section{RESUMO}

GAVINO, E. R. Produção autogestionária de janelas e adequação sociotécnica. Caso: Marcenaria Coletiva de Mulheres, assentamento rural Pirituba II, Itapeva/SP. 144 f. Dissertação (Mestrado) Programa de Pós-graduação em Arquitetura e Urbanismo do Instituto de Arquitetura e Urbanismo, Universidade de São Paulo, São Carlos, 2013.

Os estudos e práticas em iniciativas econômicas solidárias consideram diferentes dimensões da economia solidária: autogestão, gênero, empoderamento, participação de entidades de apoio e fomento e adequação sociotécnica (AST). A AST constitui-se neste contexto como mecanismo, método e ferramenta para alcance de objetivos relacionados à autogestão. Autogestão abarcada neste estudo como processo educativo. O objetivo principal da pesquisa é identificar e examinar os fatores que mais contribuíram e mais dificultaram a produção autogestionária de janelas de madeira ao longo do processo de incubação de um empreendimento econômico solidário. As estratégias gerais da pesquisa foram: pesquisa de levantamento pós-fato, estudo de caso e pesquisa-ação tendo como elemento favorecedor do estudo a participação do pesquisador como assessor do processo de incubação da marcenaria no período de 2006 a 2010. O objeto empírico da pesquisa é a produção autogestionária de janelas de madeira na Marcenaria Coletiva de Mulheres do assentamento rural Pirituba II, Itapeva/SP. Os procedimentos de coleta de dados foram: a observação direta, análise de vídeos e fotos, a sistematização de conhecimento referente ao processo de incubação e a análise de documentos. Em suma, trata-se de um estudo descritivo, exploratório e aplicado no qual foram examinadas variáveis relacionadas à autogestão e à AST. Resultados alcançados pela pesquisa foram: a caracterização da produção de janelas na Marcenaria Coletiva de Mulheres integrada a descrição do contexto histórico do empreendimento e da descrição das trabalhadoras a partir da noção de identidade social, linha do tempo com variáveis e hipóteses explicativas para exame da autogestão considerando grau de identidade do grupo em torno de valores de cooperação e solidariedade no trabalho, participação democrática nos processos decisórios, fundo coletivo e posse e cessão de uso dos meios de produção e linha do tempo com variáveis e hipóteses explicativas para exame da adequação sociotécnica considerando autoria de projeto e fabricação de produtos, capacidades adquiridas, equipamentos e dispositivos e parcerias realizadas. Como conclusão geral do estudo foi verificada a autogestão como processo de transição e avanço gradativo na prática do empreendimento.

Palavras chave: Incubação de empreendimentos econômicos solidários; Autogestão; Cadeia produtiva da madeira; Janelas de madeira. 


\begin{abstract}
GAVINO, E. R. Production of self-management windows and adequacy sociotechnical. Case: Woodwork Collective Women, rural settlement Pirituba II, Itapeva/SP. 144 f. Dissertação (Mestrado) Programa de Pós-graduação em Arquitetura e Urbanismo do Instituto de Arquitetura e Urbanismo, Universidade de São Paulo, São Carlos, 2013.
\end{abstract}

Studies and practices in economic solidarity initiatives consider different dimensions of social economy: self-management, gender, empowerment, participation of entities from support and promotion and adequacy sociotechnical (AST). The AST is in this context as a mechanism, method and tool for achieving goals related to self-management. Self-management embraced this study as an educational process. The main objective of the research is to identify and examine the factors that contributed most difficult and most self-managed production of wooden windows in a supportive economic enterprise in the incubation process. The strategies of the research were: survey research after the fact, case study and action research as having element to facilitate the participation of the study the researcher as an advisor of the incubation process of the woodwork in the period from 2006 to 2010. The object of the research is empirical self-managed production of wooden windows in Woodwork Women's Collective rural settlement Pirituba II, Itapeva / SP. The procedures for data collection were: direct observation, analysis and videos, the systematization of knowledge regarding the incubation process and document analysis. In summary, it is a descriptive, exploratory and applied in which were examined variables related to self-management and AST. Achievements of the research were to characterize the production of windows in Joinery Collective Women integrated description of the historical context of the project and the description of workers from the notion of social identity, timeline with variables and explanatory hypotheses for examination of self-management considering the degree of group identity around values of cooperation and solidarity in work, democratic participation in decision making, and collective fund ownership and right of use of the means of production and timeline with variables and explanatory hypotheses for considering the appropriateness sociotechnical authorship of the design and manufacture of products, acquired skills, equipment and devices and partnerships undertaken. As a general conclusion was verified self-management as a process of transition and gradual advance in the practice of development.

Keywords: Incubation of solidary economic enterprises; Self-Management; Wood production chain; Wooden windows. 



\section{APRESENTAÇÃO}

Os empreendimentos econômicos solidários, no âmbito de suas atividades de produção, consumo, crédito, serviços e distribuição constituem-se em alternativas de geração de trabalho e renda a população com acesso a bens e direitos historicamente negados. Estudos recentes apontam que estas práticas têm engendrado uma forma alternativa de desenvolvimento da sociedade especialmente por se articularem dentro de um movimento social denominado Economia Solidária. Igualmente, estudos apontam que a consolidação desta alternativa de desenvolvimento está diretamente relacionada a revisitação do papel da ciência e da tecnologia. Neste contexto, entendendo que mudança tecnológica vem acompanhada de mudança social, é reivindicada maior participação da sociedade nos processos de produção, uso e difusão, tanto da ciência, quanto da tecnologia, encontrando impactos importantes desta luta nos centros de produção de conhecimento acadêmicos.

As Incubadoras Tecnológicas de Cooperativas Populares (ITCPS) são atores importantes na construção de processos alternativos de produção de conhecimento e tecnologia voltados às necessidades das populações que integram o movimento da economia solidária. Estas incubadoras articulam o ensino, a pesquisa e a extensão voltando-as a realidade dos empreendimentos que incubam tomando como base diversos referenciais teóricos e metodológicos.

Pautado pela pesquisa-ação, este estudo considerou os materiais coletados, sistematizados e as observações de equipes de assessores ao longo do processo de incubação da Marcenaria Coletiva de Mulheres para verificação das hipóteses. Como parte do cumprimento da estratégia geral da pesquisa o autor deste estudo participou ativamente na observação e atuação das ações do empreendimento solidário, sujeito desta pesquisa, em especial, no desenvolvimento e produção de janelas de madeira destinadas a habitações rurais de interesse social.

Busca-se por meio desta estratégia examinar os fatores que mais contribuíram e mais dificultaram o desenvolvimento e produção de janelas de madeira autogestionariamente em uma marcenaria coletiva, em processo de incubação, localizada no assentamento rural Pirituba II, cujos membros são principalmente mulheres, mães, avós e agricultoras. Espera-se que o exame destes fatores favoreça a tomada de decisão de assessores, especialmente dos inseridos em incubadoras tecnológicas de cooperativas populares, quanto às estratégias mais adequadas de apoio ao processo de produção em empreendimentos econômicos solidários pautados pelos valores e princípios da autogestão.

Dividido em sete capítulos, esta pesquisa trará em seu primeiro capítulo um panorama geral do debate sobre a economia solidária. Serão caracterizados os elementos que 
constituem a autogestão como eixo fundador nas relações construídas no âmbito da economia solidária. Serão apresentados estudos relacionados a perspectiva de gênero e do empoderamento como forma de ampliarmos nossa compreensão sobre as estruturas de poder constituídas no âmbito das relações sociais e as alternativas de superação dos desafios impostos pela estrutura dominante. Serão apresentados os atores da economia solidária, em especial os empreendimentos econômicos solidários e as incubadoras tecnológicas de cooperativas populares como maneira de realizar o debate sobre a prática dos valores e princípios apresentados.

No segundo capítulo, serão apresentados os fundamentos teóricos que constituem a adequação sociotécnica como ferramenta para a construção de uma tecnologia adequada ao contexto dos empreendimentos econômicos solidários.

No terceiro capítulo serão apresentadas as perguntas de pesquisa, suas respectivas hipóteses explicativas e objetivos, assim como a estratégia geral e método de pesquisa utilizada.

No quarto capítulo serão caracterizados os membros do empreendimento econômico solidário estudado, o seu processo de incubação e o processo de produção de janelas de madeira para habitações de interesse social. Esta descrição trará a tona os elementos para o exame das relações entre a autogestão e adequação sociotécnica no quinto capítulo.

Diante do exposto serão apresentadas conclusões no sexto capítulo para reflexão sobre as relações entre a produção autogestionária de componentes de madeira para habitação em uma marcenaria coletiva em processo de incubação e adequação sociotécnica. Neste capítulo serão sugeridas futuras pesquisas e ações. O sétimo capítulo traz a bibliografia utilizada no estudo. 


\section{ECONOMIA SOLIDÁRIA: AUTOGESTÃO, GÊNERO E EM PODERAMENTO EM EMPREENDIM ENTOS}

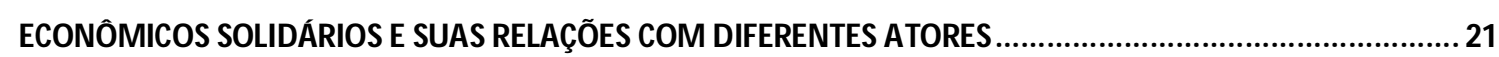

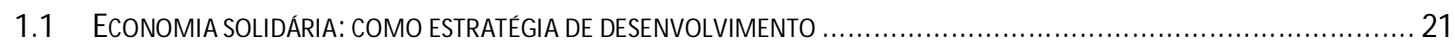

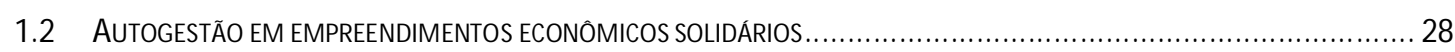

1.2.1 Experiências em andamento: estudos sobre a prática autogestionária .......................................30

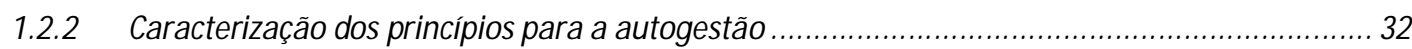

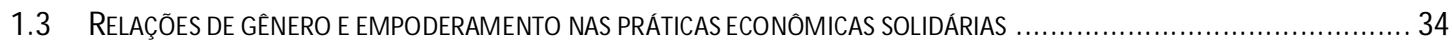

1.3.1 A produção e a reprodução na perspectiva de gênero ………................................................. 34

1.3.2 Empoderamento e as práticas econômicas solidárias.............................................................. 37

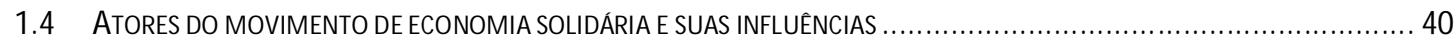

1.4.1 Gestores de políticas públicas de economia solidária ........................................................... 41

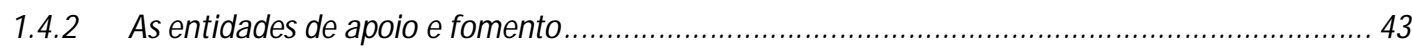

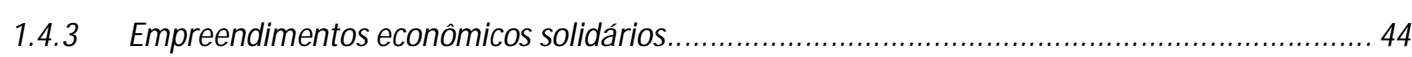

1.5 INCUBAÇÃO DE EM PREENDIM ENTOS ECONÔM ICOS SOLIDÁRIOS COM O PROCESSO EDUCATIVO ……................................. 45

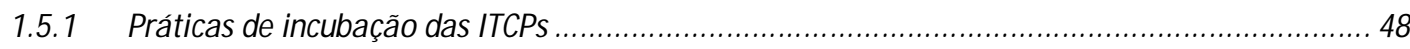

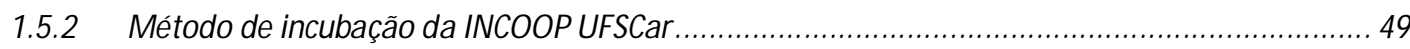

2 ECONOMIA SOLIDÁRIA E ADEQUAÇÃO SOCIOTÉCNICA ........................................................ 54

2.1 A ADEQUAÇÃO SOCIOTÉCNICA COM O BASE TECNOLÓGICA PARA A ASSESSORIA A EM PREENDIM ENTOS ECONÔM ICOS

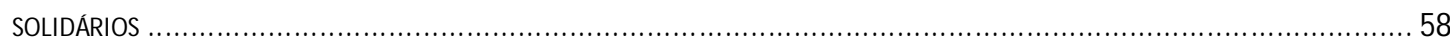

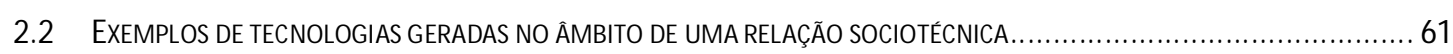

3 PERGUNTAS DE PESQUISA, HIPÓTESES, ESTRATÉGIAS DE PESQUISA E MÉTODO DE COLETA................. 67

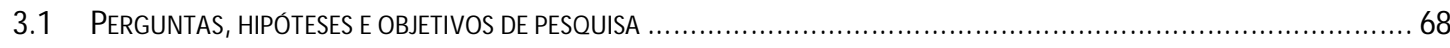

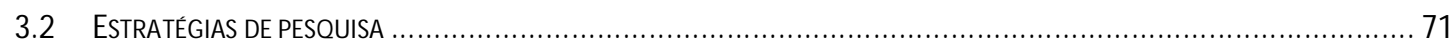

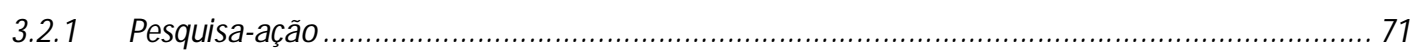

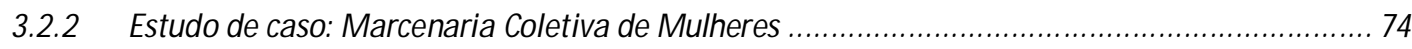

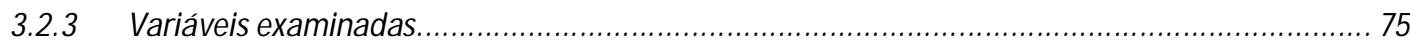

4 CARACTERIZAÇÃO DA PRODUÇÃO DE JANELAS NA MARCENARIA COLETIVA DE MULHERES................ 78

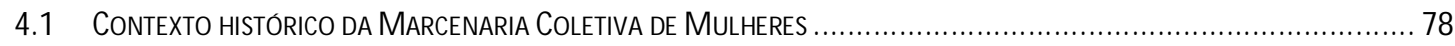

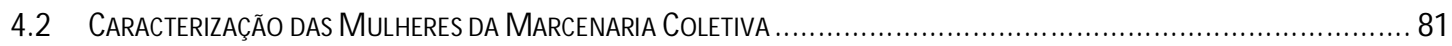

4.3 DESCRIÇÃO DOS M OM ENTOS DO PROCESSO DE INCUBAÇÃO DA M ARCENARIA COLETIVA DE M ULHERES .......................8. 84

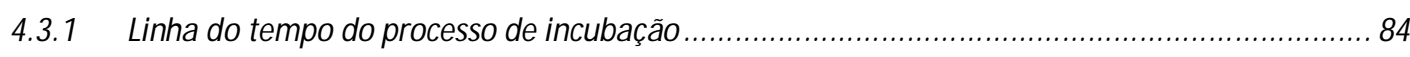

4.3.2 Caracterização dos momentos da incubação da marcenaria a partir do método de incubação proposto pela INCOOP com base na Análise do Comportamento ................................................. 89

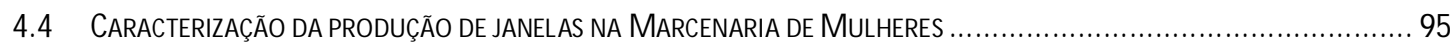


4.4.1 Janelas para o Assentamento Rural Pirituba II: caracterização das etapas de projeto e produção 96

4.4.2 Janelas para o Assentamento Sepé-Tiarajú: caracterização das etapas de projeto e produção .. 99

\section{EXAME DA PRODUÇÃO DE JANELAS: RELAÇÕES ENTRE AUTOGESTÃO E ADEQUAÇÃO SOCIOTÉCNICA 117}

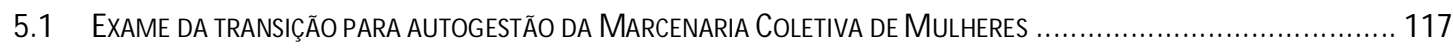

5.1.1 Aumento da posse e controle dos meios de produção pelo empreendimento........................... 119

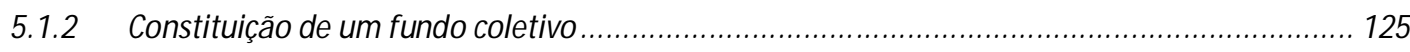

5.1.3 Participação democrática nos processos decisórios ......................................................... 127

5.1.4 Grau de identidade do grupo entorno dos valores de cooperação e solidariedade no trabalho 128

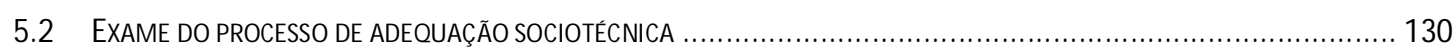

5.2.1 Parcerias, agentes externos e papéis desempenhados no processo de adequação sociotécnica 132

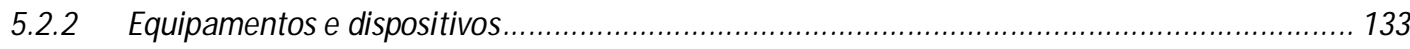

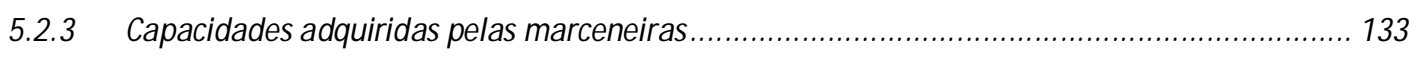

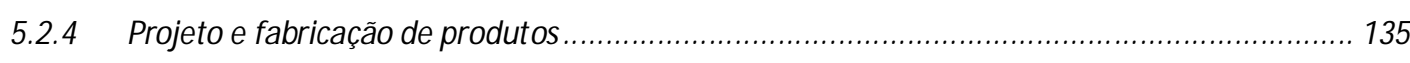

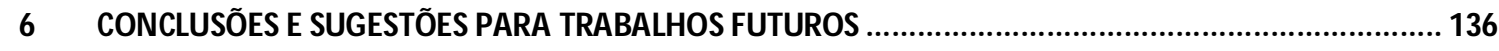

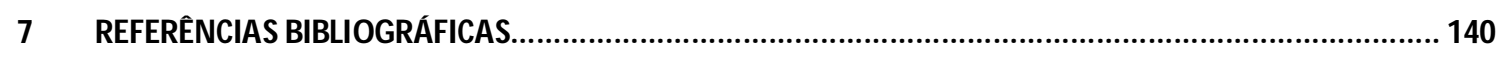




\section{LISTA DE FIGURAS}

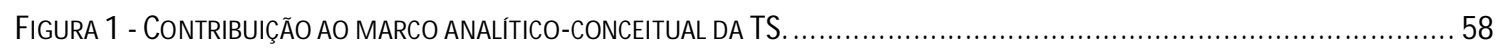

figura 2 Coletores de névoA desenvolvidos na Cidade de Chungungo (NORTE do Chile)...................................... 62

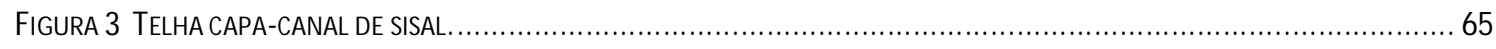

FIGURA 4 - PERGUNTAS, OBJ ETIVOSE HIPÓTESES DE PESQUISA.

FIGURA 5 - IDENTIFICAÇÃO DOS M OM ENTOS DA M ARCENARIA A SEREM CARACTERIZADOS. ............................................. 75

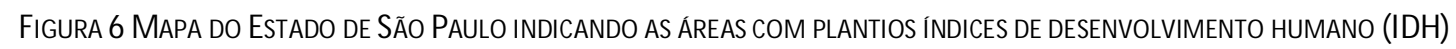

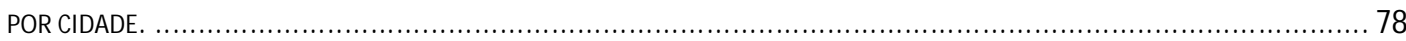

Figura 7 Linha do tem po de form ação da M arcenaria Coletiva de Mulheres, Assentam ento Rural Pirituba II,

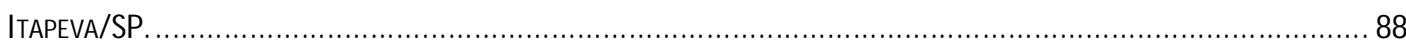

FIGURA 8 - TIPOLOGIAS E QUANTIDADES DE JANELAS PROdUZIDAS PARA O ASSENTAM ENTO RURAL SEPÉ-TIARAJú. ...................... 99

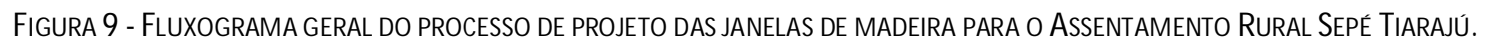
100

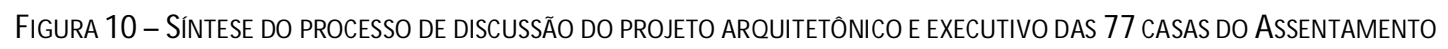
SEPÉ-TIARAJú. 101

FIGURA 11 - QUADRO COM PARATIVO ENTRE ESQUADRIAS DE M ADEIRA E M ETÁLICA, APRESENTANDO SUAS RESPECTIVAS

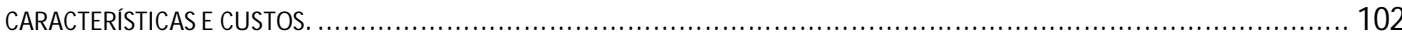

FIGURA 12 - DEFEITOS APRESENTADOS NAS FOLHAS M EXICANAS COM ENCAIXES DE M EIO REBAIXO, CUJAS FOLHAS FORAM PRODUZIDAS NA M ARCENARIA M ARCENARIA. 103

FIGURA 13 CROQUIS COM CORTE E PERSPECTIVA DA NOVA PROPOSTA DO DESENHO DA FOLHA M EXICANA PARA A ENCOM ENDA DO SEPÉ. 104

FIGURA 14 - DESENHO TÉCNICO DA JANELA COM FOLHA M EXICANA (BATENTE E FOLHAS), COM 1.18X1.15M ........................... 105

FIGURA 15 - IM AGENS REFERENTES ÀS ETAPAS DO PROCESSAM ENTO PRIM ÁRIO - DESTOPO, DESEM PENO E DESENGROSSO ............ 106

FIGURA 16 - IM AGENS REFERENTES ÀS ETAPAS DO PROCESSAM ENTO SECUNDÁRIO - EXECUÇ̃̃O DOS ENCAIXES M ACHO-FÊM EA NA TUPIA E LIXAM ENTO DAS PEÇAS. 106

FIGURA 17 - IM AGENS REFERENTES ÀS ETAPAS DA M ONTAGEM DA FOLHA M EXICANA - PRÉ-M ONTAGEM , FURAÇÃO, COLOCAÇÃO DE PARAFUSOS E DE TARUGOS. 106

FIGURA 18 - DEM ONSTRAÇÃO DE COM O DEVEM FICAR POSICIONADAS AS RÉGUAS, EM RELAÇÃO AOS ANÉIS DE CRESCIM ENTO DAS PEÇAS DE M ADEIRA.

FIGURA 19 - PROTÓTIPO DA FOLHA M EXICANA COM O USO DA M ADEIRA DE EUCALIPTO GRANDIS - 1a E 2a QUALIDADE. FONTE: ACERVO HABIS (2008). 108

Figura 20 - PARTICIPAÇÃo (VALORES EM PORCENTAGEM) DE CADA ITEM NA FORM AÇÃO DO CUSTO ESTIM ADO DA JANELA COM FOLHAS M EXICANAS. 109

FIGURA 21 - INSTALAÇÃO dAS JANELAS COM FOLHAS M EXICANAS nAS M ORADIAS do AsSENTAM ENTO RURAL SEpÉ TIARAJú (SERRA AZUL-SP).

FIGURA 22 - VISITA TÉCNICA À M ARCENARIA DE ItARARÉ-SP. (A) EXEM PLO dE UM A PORTA COM VENEZIANAS, (B) CAPACITAÇÃO PARA EXECUÇÃO DOS CORTES NOS M ONTANTES DE BORDA, COM O USO DA M ÁQUINA DESTOPADEIRA DE EIXO HORIZONTAL, (C) 
CAPACITAÇÃO PARA EXECUÇÃO DAS PALHETAS INCLINADASA $45^{\circ}$ E (D) EXEM PLO DE UM M ONTANTE DE BORDA COM OSCORTES

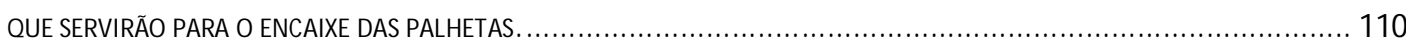

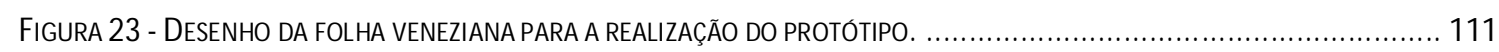

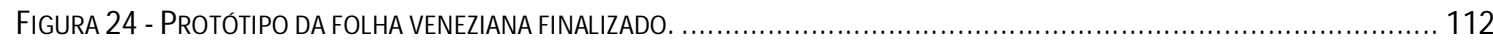

FIGURA 25 - REALIZAÇÃO DOS CORTES DAS PALHETAS PARA A PRODUÇÃO DAS 212 FOLHAS VENEZIANAS. (A) GABARITO COM INCLINAÇÃO DE 45ํ. (B) REALIZAÇÃO DOS CORTES DAS PA LHETAS NA TUPIA, COM A SERRA OSCILANTE E (C) PALHETA PRONTA.

FIGURA 26 - REALIZAÇÃO DE TESTES NA EXECUÇÃO DOS CORTES OU FRESAS NO M ONTANTE DE BORDA, NA DESTOPADEIRA, PARA AS FOLHAS VENEZIANAS. (A), (B) EXECUÇÃO DOS CORTES DOS M ONTANTES NA DESTOPADEIRA E (C) DETALHE DO M ONTANTE DE

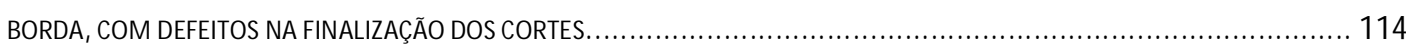

FIGURA 27 - SOLUÇÃO ADOTADA PARA A PRODUÇÃO EM ESCALA DA FOLHA VENEZIANA. (A) EXECUÇÃO DOS CORTES NOS M ONTANTES, NA SERRA ESQUADREJADEIRA, COM O AUXILIO DE UM GABARITO À 45; (B) M ONTANTESJÁ COM OS CORTES INCLINADOS; (C) M ONTAGEM DAS PALHETAS NOS M ONTANTES. 116

FIGURA 28 - SOLUÇÃO ADOTADA PARA A PRODUÇÃO EM ESCALA DA FOLHA VENEZIANA. (A) M ONTAGEM DA FOLHA VENEZIANA; (B) M ONTAGEM DA FOLHA VENEZIANA FINALIZADA; (C) EXEM PLO DE UM A CASA DO SEPÉ COM A FOLHA VENEZIANA INSTALADA. 116

FIGURA 29 - LINHA DO TEM PO CONTENDO A SÍNTESE DO EXAME DO PROCESSO DE TRANSIÇÃO PARA AUTOGESTÃO DA M ARCENARIA COLETIVA DE M ULHERES CONTENDO AS VARIÁVEIS IDENTIFICADAS E AS HIPÓTESES VERIFICADAS. 118

Figura 30 Evolução do Consum o Aparente e dos Preços de M adeira, Estado de São Paulo, 1995 a 2007. 123

FIGURA 31 LINHA DO TEM PO CONTENDO A SÍNTESE DO EXAM E DO PROCESSO DE ADEQUAÇÃO SOCIOTÉCNICA DA M ARCENARIA COLETIVA DE M ULHERES CONTENDO AS VARIÁVEIS IDENTIFICADAS E AS HIPÓTESES VERIFICADAS. 131

FIGURA 32 SíNTESE DAS HABILIDADES E CAPACIDADES ADQUIRIDAS PELAS M ARCENEIRAS AO LONGO DOS M OM ENTOS DO PROCESSO DE PRODUÇÃO DASJANELAS. 


\section{LISTA DE TABELAS}

TABELA 1 - SINOPSE COM PARATIVA ENTRE "EM PRESAS CONVENCIONAIS" E "INICIATIVAS DE ECONOM IA SOLIDÁRIA" .................... 24

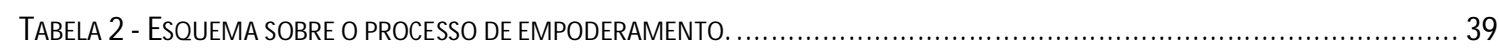

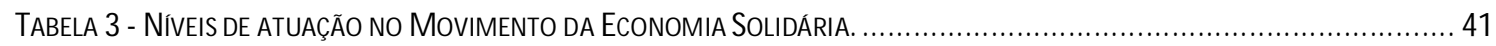

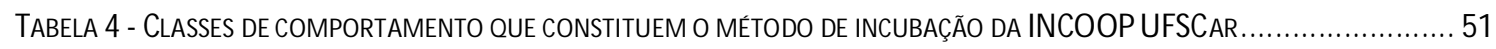

TABELA 5 - ClaSSE dE COM PORTAM ENTO ASSESSORAR O GRUPO INCUBADO PARA LIDAR COM PROCESSOS DE PRODUÇÃO, USO E

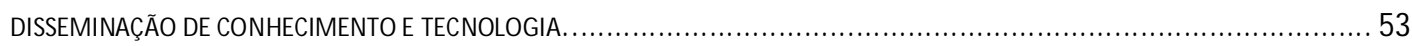

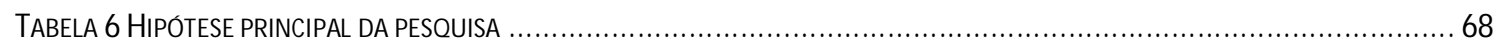

TABELA 7 - CLASSES DE VARIÁVEIS, SUBCLASSES De VARIÁVEIS E VARIÁVEIS EXAM INADAS. .............................................. 76

TABELA 8 - PLANEJAM ENTO DE COLETA DE DADOS SEGUNDO HIPÓTESES INTERM EDIÁRIAS PARA OS COM PONENTES DE M ADEIRA PARA

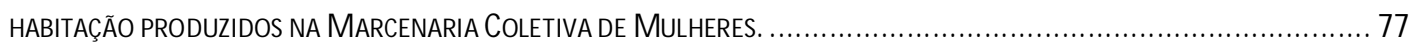

TABELA 9 COM PONENTES EM MADEIRA PARA HABITAÇÃO DE INTERESSE SOCIAL PRODUZIDOS AO LONGO DO PROCESSO DE INCUBAÇÃO

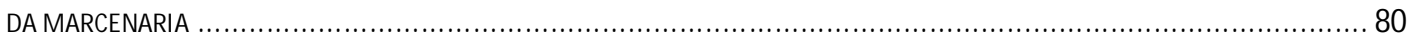

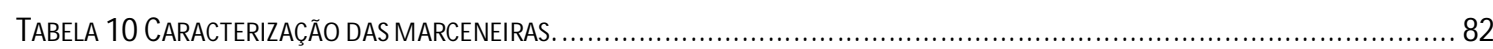

TABELA 11 CARACTERIZAÇÃO dAS M ARCENEIRAS A PARTIR DE OLHARES DE DENTRO (ENDOGRUPO) E DE OLHARES DE FORA DO GRUPO

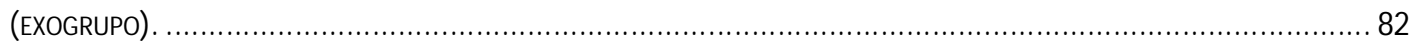

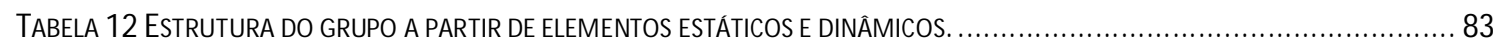

TABELA 13 ALTERNATIVAS PARA EXECUÇÃo DOS CORTES PARA O ENCAIXE DAS PALHETAS NOS M ONTANTES. ........................... 114

TABELA 14 LeVANTAM ENTO dE EQUIPAM ENTOS ADQUIRIDOS E IDENTIFICAÇÃO DA POSSE DA PROPRIEDADE. .......................... 120

TABELA 15 LEVANTAM ENTO DAS INSTALAÇõES EXECUTADAS E IDENTIFICAÇÃO DA POSSE DA PROPRIEDADE............................ 122 



\section{ECONOMIA SOLIDÁRIA: AUTOGESTÃO, GÊNERO E EMPODERAMENTO EM EMPREENDIMENTOS ECONÔMICOS SOLIDÁRIOS E SUAS RELAÇÕES COM DIFERENTES ATORES}

Nesse capítulo será apresentado o debate travado nas últimas décadas sobre a economia solidária e sua relação com as dimensões da vida. Esta apresentação trará as bases teóricas, metodológicas e práticas para, por um lado, ampliar o universo de fenômenos abarcados por esta pesquisa e, por outro lado, delimitar o papel da universidade, em especial a pública, na definição de uma estratégia para outro desenvolvimento. Como princípio central na constituição deste outro desenvolvimento, a autogestão será apresentada em seus aspectos teóricos e práticos com o objetivo de identificar variáveis importantes para sua efetivação na realidade. As questões e indicações efetuadas pelas abordagens de gênero e de empoderamento serão citadas, na medida em que questionam a estrutura dominante e apresentam alternativas de superação das contradições no âmbito das relações sociais. Serão apresentados os atores envolvidos no processo de conformação desta estratégia a partir de seus papéis na prática de um conjunto de princípios relacionados às várias dimensões da economia solidária. Serão caracterizados os empreendimentos econômicos solidários (EESs) como centralidade da prática autogestonária e foco do apoio dos demais atores da economia solidária, em especial, das incubadoras tecnológicas de cooperativas populares (ITCPs). Serão caracterizadas as ITCPs e suas formas de atuação por meio de métodos de incubação. Como maneira de aprofundar na revisão sobre os métodos de incubação serão apresentados de maneira suscinta os fundamentos teóricos e metodológicos que embasam a atuação da Incubadora Regional de Cooperativas Populares da Universidade Federal de São Carlos (INCOOP UFSCar) na assessoria a EES.

\subsection{Economia solidária: como estratégia de desenvolvimento}

Como fenômeno contemporâneo e mundial, a economia solidária abarca várias compreensões e perspectivas históricas e futuras de sua existência. De acordo com CHANIAL e LAVILLE (2006), na Europa, após uma ampla crise econômica e cultural que marcou o final dos anos de 1960, as exigências por uma "maior qualidade de vida" se fez presente a partir da reivindicação de um crescimento qualitativo e de uma política do nível de vida, "de levar em conta as dimensões de participação nas diferentes esferas da vida social, de preservar o meio ambiente, de mudar as relações entre os sexos e as idades" (CHANIAL e LAVILLE, 2006). É nesse quadro que a década seguinte é marcada por uma renovação das atividades associativas que testemunham não só uma alternativa à 
crise do emprego, mas também o desejo de "trabalhar de outra maneira". Assim, na década de 19700 desemprego em massa aparece como consequência e resposta aos efeitos do capitalismo e da globalização. Aqueles que não tinham emprego, não o conseguiam e os empregados enfrentaram mudanças na forma de trabalhar, como diminuição de seus direitos e reduções salariais, isso sem contar a grande competição que assustou os cidadãos diante da disputa por um posto de trabalho.

Dessa forma, a economia solidária voltou a ganhar força nas últimas décadas tendo que ser segundo Singer, "reinventada", e seus valores de solidariedade, honestidade, democracia, autogestão, autonomia e livre adesão reafirmados. Nesse momento vemos os países divididos a partir de duas questões ideológicas: de um lado aqueles que lutam pelo capitalismo e de outros aqueles que "sentem-se desafiados a buscar outro modo de sociedade que supere o capitalismo, em termos de igualdade, liberdade e segurança para todos os cidadãos" (SINGER, 2002).

Lechat (2002) remonta as origens do conceito da economia solidária por meio da análise de um conjunto teórico encontrado na literatura brasileira e internacional para definir a identidade deste fenômeno contemporâneo como parte do que se constitui o terceiro setor ou, como reivindicado pela autora, economia social. Em seus estudos, Lechat (2002) reafirma a economia solidária como contraponto ao projeto de desenvolvimento capitalista neoliberal, portanto, como um novo paradigma socioeconômico, político e cultural fundamentado na solidariedade como ferramenta de enfrentamento dos problemas decorrentes do sistema capitalista como, por exemplo, diante do desemprego temos o enfrentamento por meio da reinserção de desempregados em empreendimentos solidários ou diante do fechamento de empresas temos o enfrentamento por meio da ocupação pelos próprios trabalhadores das empresas agora autogeridas.

Esta potencialidade da economia solidária é resgatada atualmente por programas sociais, especialmente do governo federal. Neste ano de 2011, o governo federal brasileiro anunciou 0 plano "Brasil Sem Miséria"1 que, dentre outras ações, aponta o fomento a economia popular solidária como ferramenta importante de inclusão social produtiva ocupando-se da população em extrema pobreza (população com renda per capita familiar abaixo de 70 reais mensais). Desta maneira, o plano resgata a economia solidária como uma ferramenta para pobres e excluídos.

\footnotetext{
1 Disponível em: <http://www. http://www.brasilsemmiseria.gov.br> Acesso em: 26 novembro 2011
} 
Contudo, a definição da economia solidária como, segundo Singer (2003), "mera resposta às incapacidades do capitalismo" deve ser superada para uma definição que a entenda como uma alternativa superior ao capitalismo.

Superior não em termos econômicos estritos, ou seja, que apenas as empresas solidárias regularmente superariam suas congêneres capitalistas, oferecendo aos mercados produtos ou serviços melhores em termos de preços e/ou qualidade. A economia solidária foi concebida para ser uma alternativa superior por proporcionar às pessoas que a adotam, enquanto produtoras, poupadoras, consumidoras, etc., uma vida melhor (SINGER, 2003).

Esta postura aponta a economia solidária como um modo de distribuição, produção, consumo, crédito e troca que destituirá o capitalismo de sua atual hegemonia. Devemos entender que esta postura do Singer indica aspectos importantes, dentre eles, que é necessário um período de transição de um sistema a outro e que esta transição será bem-sucedida caso se ampliem as práticas econômicas solidárias de maneira livre e espontânea para alcance de uma vida melhor a todos os participantes. Neste contexto, Singer (2003) coloca que uma sociedade só conseguiria ser igualitária se adotasse o princípio da distribuição ao invés da acumulação, se a economia fosse solidária ao invés de competitiva.

Desta forma, a economia solidária se configura como uma "outra economia" uma vez que se contrapõe aos valores do sistema de produção capitalista. Quais os valores do sistema capitalista contrapostos pela economia solidária? Giannotti (1976) apud Cruz (2004) caracteriza o modo de produção capitalista a partir da reunião de quatro características da vida econômica, até então separadas: a) um regime de produção de mercadorias, de produtos que não visam senão ao mercado; b) a separação entre os proprietários dos meios de produção e os trabalhadores, desprovidos e objetivamente apartados daqueles meios; c) a conversão da força-de-trabalho igualmente em mercadoria, sob forma de trabalho assalariado; d) a extração da mais-valia, sobre o trabalho assim cedido ao detentor dos meios de produção, como meio para a ampliação incessante do valor investido na produção; a mais-valia é a finalidade direta e o móvel determinante da produção, cabendo à circulação garantir a realização do lucro e a reposição ampliada do capital. O capitalismo, portanto, está fundado numa relação social, entre indivíduos desigualmente posicionados face aos meios de produção e às condições de posta em valor de sua capacidade de trabalho. Uma relação classista, que se efetua, "através de uma colaboração ilusória, mas não menos real, das três classes básicas, os assalariados, os capitalistas e os proprietários fundiários, na qualidade de donos dos fatores responsáveis pelos custos da produção de mercadorias." (GIANNOTTI, 1976, p. 164 apud CRUZ, 2004, p. 104). A Tabela 1 compara as empresas no âmbito de sistemas econômicos antagônicos expondo as diferenças marcantes delas: 
Tabela 1 - Sinopse comparativa entre "empresas convencionais" e "iniciativas de economia solidária".

\begin{tabular}{|c|c|c|}
\hline & Empresa convencional & Iniciativa de economia solidária \\
\hline $\begin{array}{l}\text { Forma de propriedade dos } \\
\text { meios de produção }\end{array}$ & $\begin{array}{l}\text { Separação entre produtores diretos e } \\
\text { proprietários. }\end{array}$ & $\begin{array}{llll}\begin{array}{l}\text { Os produtores } \\
\text { proprietários. }\end{array} & \text { diretos são } & \text { OS } \\
\end{array}$ \\
\hline Participação nas decisões & $\begin{array}{l}\text { Separação das funções, sobretudo em } \\
\text { relação às decisões-chave no } \\
\text { empreendimento. } \\
\text { Decisões vinculadas à propriedade: } \\
\text { alienação dos produtores. } \\
\text { Poder de decisão, e distribuição dos } \\
\text { resultados, de acordo com as quotas } \\
\text { de capital dos proprietários ou } \\
\text { acionistas. }\end{array}$ & $\begin{array}{l}\text { Indistinção entre agentes de } \\
\text { concepção e execução. } \\
\text { Decisões vinculadas à propriedade- } \\
\text { trabalho: implicação direta dos } \\
\text { trabalhadores-produtores. } \\
\text { Poder de decisão, e distribuição dos } \\
\text { resultados, de acordo com as decisões } \\
\text { soberanas da assembleia de sócios, } \\
\text { onde cada associado tem um voto. }\end{array}$ \\
\hline Relações de trabalho & $\begin{array}{l}\text { Remuneração do trabalho através de } \\
\text { salário ou contratação precária de } \\
\text { serviços. }\end{array}$ & $\begin{array}{l}\text { Distinções de rendimentos são } \\
\text { admitidas apenas coletivamente, em } \\
\text { função de critérios de mediação com o } \\
\text { mercado. }\end{array}$ \\
\hline $\begin{array}{l}\text { Fator de } \\
\text { estruturante }\end{array}$ & Capital. & Trabalho. \\
\hline $\begin{array}{l}\text { Controle das tecnologias e } \\
\text { do conhecimento }\end{array}$ & Submetido ao sistema de hierarquias. & $\begin{array}{l}\text { Tensões e sínteses conflitivas em } \\
\text { torno do acesso e do fluxo das } \\
\text { informações }\end{array}$ \\
\hline Motivação para empreender² & $\begin{array}{l}\text { Defesa de níveis de vida anteriores, } \\
\text { busca de lucros e auto-realização } \\
\text { individual pela competição. }\end{array}$ & $\begin{array}{l}\text { Defesa do emprego, sobrevivência } \\
\text { econômica e identidade grupal. }\end{array}$ \\
\hline $\begin{array}{l}\text { Financiamento do capital } \\
\text { inicial }\end{array}$ & $\begin{array}{l}\text { Através de capital previamente } \\
\text { acumulado pelo(s) empreendor (es) ou } \\
\text { através do sistema bancário, mediante } \\
\text { garantias patrimoniais. }\end{array}$ & $\begin{array}{l}\text { (a) Inexistente, ou (b) pela reunião das } \\
\text { ferramentas de propriedade e uso dos } \\
\text { empreendedores ou (c) através de } \\
\text { créditos oriundos de fundos especiais } \\
\text { ("solidários"). }\end{array}$ \\
\hline
\end{tabular}

Fonte: Adaptado de CRUZ, 2004

Com a centralidade no trabalho, o autor evidencia as diferenças entre os vários aspectos que operacionalizam e caracterizam as empresas convecionais e as iniciativas econômicas solidárias. Os valores econômicos solidários expressados são: a iniciativa coletiva, as tomadas de decisões compartilhadas e a posse coletiva dos meios de produção. Como contrapartida 0 autor evidencia desafios relacionados a prática solidária: como dificuldades relacionadas ao fluxo de informações e ao acesso a capital inicial. Faz-se necessário evidenciar outros aspectos que diferenciam as duas categorias de trabalho, como por exemplo: as questões de gênero e a produção da tecnologia.

2 Um esclarecimento importante sobre esta questão está presente no texto de BACIC, BALDEÓN e ALMEIDA (2004). 
Para além da dicotomia entre os sistemas hegemônico e solidário, autores declaram a possibilidade de existência mútua de várias economias. Neste sentido é importante ressaltar que há percepções da economia solidária que a deslocam de uma relação de dicotomia com a estrutura dominante e a conceituam como uma alternativa econômica viável no âmbito de uma articulação entre economias. Esta perspectiva da economia solidária é adotada por França Filho \& Junior (2010) o qual a aborda como inserida em um contexto de economia plural, articuladora entre economias (mercantil, não mercantil e monetária), partindo de uma concepção mais ampla do fato econômico, permitindo a multiplicidade de formas de produzir e distribuir riquezas.

[...] a noção de economia plural, que aqui adotamos como desdobramento da opção por uma definição substantiva de economia, corresponde à ideia de uma economia que admite uma pluralidade de formas de produzir e distribuir riquezas. Esse modo de conceber (ou entender) o funcionamento da economia real, além de ampliar o olhar sobre o econômico, para além de uma visão dominante que reduz seu significado à ideia de economia de mercado, permite ainda perceber certas singularidades próprias às práticas de economia solidária (FRANÇA FILHO \& JUNIOR, 2010).

Aqui aparece a definição de economia plural como espaço para manifestações e iniciativas além da possível existência de uma economia dominante. Esta definição permite ao autor pensar as práticas de economia solidária como modos de gestão de diferentes lógicas em tensão nas dinâmicas organizativas. Assim, segundo França Filho (2006 a), a dinâmica desse campo parece evoluir de formas de auto-organização socioeconômicas, para formas de auto-organização sociopolíticas as quais ao invés de concebê-la como uma "nova economia", que viria somar-se às formas dominantes de economia numa espécie de complemento que serviria de ajuste às disfunções do sistema econômico vigente, como se a economia solidária tivesse a função de ocupar-se dos pobres e excluídos do sistema econômico, constituindo uma espécie de setor à parte, a economia solidária seria concebida com um papel funcionalmente bem definido em relação ao conjunto.

Há divergências claras entre as abordagens explicitadas, especialmente, no que se ao papel da economia solidária diante do conjunto das relações políticas, econômicas e sociais. Uma abordagem que nos parece mais coerente com o que se espera da economia solidária como movimento social é a perspectiva da economia solidária construída e desejada como estratégia de desenvolvimento. Esta abordagem é verificada nos diagnósticos e diretrizes lançados na II Conferência Nacional de Economia Solidária realizada em Brasília em junho de 2010, convocada para debater 0 tema: "O direito às formas de organização econômica baseadas no trabalho associado, na propriedade coletiva, na cooperativa e na autogestão, reafirmando a economia solidária como estratégia e política de desenvolvimento". Esta conferência ocorreu em um momento de expansão e fortalecimento das práticas e valores do associativismo e da cooperação em iniciativas de organização da produção, de 
serviços, de crédito e finanças solidários, de comércio justo e de consumo responsável. E dentre outras bandeiras em meio a este contexto, foi anunciado nesta conferência que um grande desafio da economia solidária será de "afirmação e reconhecimento como modelo de desenvolvimento sustentável e solidário, como forma de organização econômica cuja finalidade principal é a redução das desigualdades de renda e de riqueza" (II CONAES, 2010).

O reconhecimento da economia solidária como estratégia de desenvolvimento não implica, por um lado, a distituição de outras abordagens da economia solidária uma vez que a definição da economia solidária como um movimento social incorre em aceitar as mudanças constantes que se constroem em meio as interlocuções dos diversos atores do movimento. Mas, por outro lado, nos favorece a identificação dos avanços e limites da economia solidária no Brasil e, a partir desta identificação é possível indicar aspectos para aperfeiçor as estratégias e instrumentos efetivos de atuação do movimento.

Estudos já avançaram no sentido de distinguir fatores importantes de atenção do movimento com o foco na noção de desenvolvimento. Gaiger (2004) aponta como necessário

[...] romper fronteiras - sociais, geográficas - , superar limites - mentais, políticos, institucionais - e favorecer convergências inclusivas, de integração sistêmica da economia solidária, de modo a convertê-la em base social e econômica tangível de outro modelo de desenvolvimento. Do contrário, a multiplicação de iniciativas concretas pode deparar-se em pouco tempo com a ausência de ambientes e de mecanismos de retroalimentação, com 0 risco de vir a refluir e de estabelecer-se um quadro crítico, com tendências à estagnação (GAIGER, 2004).

O mesmo autor reforça esta identidade da Economia Solidária e sua necessária integralização na prática.

Sem que se renovem profundamente alguns dos paradigmas políticos vigentes, transferidos em sua maioria de outras frentes de militância e ação institucional para a economia solidária, esta se verá fadada a funcionar como mais um campo de disputas, entre frações e organizações mediadoras, e não de autêntico e inovador protagonismo social (GAIGER, 2004).

Neste contexto é necessário entendermos qual tipo de desenvolvimento é esperado em contraposição ao desenvolvimento imposto pela estrutura dominante. Assim como Singer e Coraggio, nos parece importante identificar o desenvolvimento como voltado ao aumento da qualidade de vida de todos.

Desarolarmos es ampliar y efectivizar nuestras capacidades como sociedades para construir e institucionalizar una economía donde quepan todos, una economía de lo suficiente, una economía solidaria que dé respuesta material a los deseos legitimados de todos sus ciudadanos miembros. Esto nos diferencia de la búsqueda del bienestar, concepto propio de la modernidad occidental que terminó definiendo la riqueza como la masa de mercancías que 
se generan y distribuyen, y el bienestar individual como la cuota de esa riqueza de que se podía obtener (CORAGGIO, 2008, grifo do autor).

Importante ressaltar a importância das redes na operacionalização desta estratégia para a economia solidária uma vez que, segundo Gaiger (2004), desloca o foco de atenção da resolução dos problemas públicos para o território, no entanto, o problema ou a questão do como agir no território permanece, assim como, a questão de como gerar iniciativas que reflitam sobre "como ir além de êxitos isolados e de ações focalizadas".

França Filho \& Junior (2010) examinam as potencialidades das metodologias e técnicas de intervenção para um desenvolvimento local a partir do fortalecimento de práticas de economia solidária. Colabora para este exame o pressuposto de que a economia solidária se constitui de "iniciativas de natureza associativa ou cooperativista envolvendo moradores num determinado contexto territorial que buscam a resolução de problemas públicos concretos relacionados à sua condição de vida no cotidiano, através do fomento à criação de atividades sócio-econômicas". Apresenta-se assim, a chave do embate colocado pelos autores: a construção conjunta de oferta e demanda em um determinado território. "Tal economia estimula, então, no território um circuito integrado de relações socioeconômicas envolvendo produtores e/ou prestadores de serviço em articulação com consumidores e/ou usuários de serviços, numa lógica de rede de economia solidária". Os autores apontam que a construção conjunta da oferta e da demanda quebra com os paradigmas constituídos no âmbito de uma relação estritamente mercantil.

Assim, neste tipo de economia, a consideração sobre oferta e demanda como entidades abstratas (supostamente vocacionadas a harmonizar-se sempre, graças à ação transcendente de uma mão invisível - num processo mais conhecido como auto-regulação do mercado) perde sentido. Do mesmo modo que a competição também deixa de ter importância nesta lógica. Isto porque o objetivo da rede é a ruptura com a dicotomia habitual (em regimes de mercado supostamente auto-regulado) entre a produção e o consumo (pelos seus efeitos danosos muitas vezes em temos sociais...) e o estímulo a livre associação entre produtores e consumidores (ou prestadores de serviços e usuários), permitindo a afirmação do conceito de prossumidores.

Nesta economia de prossumidores, a regulação ocorre através de debates públicos concretos no espaço associativo, num exercício de democracia local em que os próprios moradores planejam e decidem sobre a oferta de produtos e/ou serviços (ou seja, a criação das atividades sócio-econômicas) em função das demandas efetivas identificadas precedentemente por eles próprios.

Finalmente, a construção conjunta da oferta e da demanda como característica-chave dessa outra economia estimulada supõe ainda, no nível da ação, uma articulação fina entre dimensões sócio-econômica e sócio-política. Isto porque a elaboração das atividades sócioprodutivas conjuga-se a uma forma de ação pública: trata-se de moradores num determinado território debatendo politicamente seus problemas comuns e decidindo seu destino. Tais iniciativas têm vocação, desse modo, a constituírem-se também como formas inéditas de espaço público em seus respectivos territórios de pertencimento (FRANÇA FILHO; JUNIOR, 2010, p.4). 
A definição de "prossumidores" exposta pelos autores a partir de considerações sobre a dinâmica da oferta e da demanda no âmbito de um circuito solidário expõe uma nova dimensão da construção do bem-estar comum e da qualidade de vida de todos que é a noção de um novo espaço público onde são debatidos os problemas e expostas às alternativas deslocando as soluções para outras esferas comunitárias e não mais para o Estado.

Estudos apontam que a efetivação do bem-estar nas várias dimensões da vida deve ser permeada pela construção de estruturas equânimes de poder. Estes mesmos estudos defendem a autogestão como perspectiva importante de construção desta premissa. Estudos relacionados à perspectiva de gênero e empoderamento também devem ser considerados para efetivação de quaisquer estruturas de espraiamento do poder.

\subsection{Autogestão em empreendimentos econômicos solidários}

Há vários significados e compreensões sobre autogestão. Várias são as abordagens do conceito como forma de organização produtiva identificada em diferentes momentos históricos e como proposta de gestão e organização para diferentes atividades econômicas, políticas e sociais urbanas e rurais. Alguns autores apontam o uso sistemático do termo autogestão para designar uma prática gerencial e outros o associam a uma prática de transformação e de mudança social. Há ainda, aqueles que apontam 0 desgaste do termo frente às distorções causadas pelas apropriações inerentes a uma sociedade industrial e de consumo. Percebem-se no cotidiano e em particular no movimento da Economia Solidária dificuldades de incorporação do conceito, dos princípios e das principais abordagens da autogestão.

Vários autores examinam o conceito de autogestão para compreender a essência: "desde sua origem as experiências autogestionárias sempre estiveram relacionadas com as lutas dos trabalhadores e principalmente do movimento operário" (ALBUQUERQUE, 2003, p.21). Esta afirmação indica a importância de se localizar as experiências autogestionárias como "práticas sociais que se construíram, são localizadas, datadas e legitimadas historicamente". A essência do conceito com bases no movimento operário legitima o caráter social do termo. Segundo o referido autor, há outra vertente que assume o conceito para designar apenas uma "técnica gerencial que possibilita reduzir defeitos de produção e aumentar a produtividade". É necessário apontar ainda, que esta "crítica radical" ao modelo econômico-político-social hegemônico a qual Albuquerque (2003) cita como caráter essencial da autogestão, no âmbito da Economia Solidária, ganha corpo e elementos para incorporá-la como prática emancipadora do trabalhador. Para efetivar o caráter de crítica a qual a autogestão constitui é necessário superar, também, as abordagens distorcidas da autogestão. 
Nas empresas capitalistas, os principais argumentos a favor das "novas" formas de organização do trabalho, intituladas "autogestão", neutralizam seu caráter de crítica radical porque são apresentadas apenas como mais uma técnica gerencial que possibilita reduzir defeitos de produção e aumentar a produtividade. (ALBUQUERQUE, 2003, p. 23).

Em uma abordagem político-social, Nascimento (2003), concebe a autogestão como uma nova organização na perspectiva da concretização e caracterização do socialismo onde: "[...] apenas pela via da autogestão será possível a criação de um novo modo de produção, sob a gestão direta dos trabalhadores." Traz assim, a autogestão como elemento comum de todas as experiências históricas de luta operária. Segundo o autor, esta autogestão como base do socialismo, é incluída a partir do poder de gestão, de decisão e de controle nas mãos dos trabalhadores. Nesta abordagem é importante incluir a perspectiva do socialismo para a compreensão da economia solidária, principalmente, para os excluídos historicamente do mundo do trabalho e dos direitos sociais, os retirando da posição de objetos levando-os a condição de sujeitos capazes de pensar, analisar e transformar a realidade em que vivem.

\begin{abstract}
A autogestão é a construção permanente de um modelo de socialismo, em que as diversas alavancas do poder, os centros de decisão, de gestão e controle e os mecanismos produtivos sociais, políticos e ideológicos, se encontrem nas mãos dos produtores-cidadãos, organizadas livres e democraticamente, em formas associativas criadas pelos próprios produtores-cidadãos, com base no princípio de que toda organização deve ser estruturada da base para a cúpula e da periferia para o centro, nas quais se implantem a vivência da democracia direta, a livre eleição e revogação, em qualquer momento das decisões, dos cargos e dos acordos. (NASCIMENTO, 2003, p.226)
\end{abstract}

Albuquerque (2003) e Nascimento (2003) delimitam o caráter multidimensional do conceito (social, econômico, político e técnico) e da prática da autogestão na medida em que devem ser percebidos como a sustentação da busca de uma autonomia gerencial da produção e de todos os domínios da vida dos trabalhadores pela posse dos mesmos.

Bookchin (1980), em seu texto "Autogestão e Tecnologias Alternativas", associa as diferentes etapas ou interpretações do conceito autogestão ao desenvolvimento das técnicas e que a aproximação se torna mais latente nos dias de hoje quando a autogestão é concebida principalmente em termos econômicos, tais como "controle operário", "democracia industrial", "participação dos trabalhadores". Relacionando autogestão e tecnologia o autor expõe:

Falamos de uma formação econômica que se relaciona com 0 trabalho, o emprego dos materiais e das máquinas, bem como com a repartição social dos recursos materiais. Em suma nós falamos das técnicas ou da tecnologia. (BOOKCHIN, 1980).

No excerto observamos o intuito do autor em demonstrar que se torna insuficiente analisar a palavra autogestão apenas sob a ótica do "controle operário", da "democracia industrial" e da 
"participação dos trabalhadores" sem levar em consideração sua associação com o desenvolvimento da técnica. Em certo sentido os três autores citados se complementam comprovando a complexidade do tema.

Há outros autores que avaliam a prática da autogestão do ponto de vista do subjetivo, da dimensão sócio-psicológica, do aumento da criatividade dos cooperantes, grau de autonomia em fim, do ponto de vista qualitativo da prática autogestionária para além dos aspectos econômicos da autogestão.

É importante o debate sobre as controvérsias entre os diferentes autores para a compreensão das experiências autogestionárias e das manifestações atuais da economia solidária.

\subsubsection{Experiências em andamento: estudos sobre a prática autogestionária}

A discussão da autogestão em alguns EESs no Brasil remonta a discussão do papel das mesmas na divisão social do trabalho. Um dos estudos sobre as cooperativas de calçado no Rio Grande do Sul considera a análise de quatro casos, escolhidas a partir de algumas característicaschave: tipo de produção (produto terceirizado ou produto próprio); origem (sindicato, empresa, grupo de desempregados) e tamanho. Icaza (2004), autora do referido estudo, assume como conceito de autogestão as abordagens sobre a tomada de decisão e posse dos meios:

[...] uma empresa autogerida é uma organização produtiva sobre a qual o poder de decisão último pertence de forma exclusiva a seus trabalhadores e é repartido de forma igualitária entre todos eles, qualquer que sejam suas qualificações ou seus aportes em capital. (ICAZA, 2004, p.57).

Através de uma revisão teórica a autora então, submete as experiências tratadas a eixos estruturadores chamados de "aspectos do cotidiano das cooperativas", quais sejam:

[...] a organização do trabalho e da produção, a participação democrática no processo decisório, o grau de identidade do grupo de associados em torno de valores de cooperação e solidariedade no trabalho, e a presença de uma visão autogestionária (grifo da autora) mais ampla [...] (ICAZA, 2004, p.57).

Alguns elementos na pesquisa de Icaza (2004) permitem a identificação de algumas considerações e limites para a economia solidária. Os elementos analisados são quanto aos resultados econômicos e as perspectivas de desenvolvimento das cooperativas estudadas e quanto à cooperação e autogestão na perspectiva dos desafios para romper a cultura taylorista-fordista. A partir da análise destes elementos, a autora, começa a destacar características que indicam as dificuldades para a construção da autogestão. 
Dentre as cooperativas analisadas pela referida autora algumas conjugam trabalho e renda com o projeto de produzir sem a exploração, pelo proprietário, dos meios de produção e outras apenas como opção viável de trabalho e renda frente às condições de desemprego crescente. Para a autora, este panorama em que se originam as maiorias das cooperativas, traz a tona um dos principais limites e elementos que explicam a desistência de trabalhadores que é o confronto entre 0 "diferencial do trabalho coletivo" e a "cultura de firma" entendida como acomodação às vantagens da estabilidade e dos direitos que proporciona o emprego formal pelos trabalhadores.

Para ilustrar o panorama mostrado acima, a autora indica, através de um quadro de caracterização das cooperativas estudadas, que o surgimento das cooperativas é delineado por grupos de trabalhadores, na sua grande maioria, ex-operários de fábricas falidas em contato com o movimento sindicalista os quais buscam trabalho com geração de renda. Aponta, ainda, que o início de produção destas cooperativas é dentro de condições de terceirização de serviços para grandes e médias empresas levando os trabalhadores, segundo a autora, ao exercício de funções complementares dentro da organização produtiva.

A autora discorre sobre a baixa autonomia em grupos que trabalham com a terceirização da produção de grandes empresas:

[...] uma análise dos casos estudados mostra as dificuldades dos trabalhadores para se apropriarem do saber fundamental do processo produtivo, tendendo a intervir apenas nos espaços mais operacionais. Nesse sentido, os avanços obtidos, pelo fato de produzir coletivamente, são limitados quando se percebe que os detentores do saber continuam estando em outros lugares dentro da organização do processo produtivo. (ICAZA, 2004, p.58).

O fato dos EES estarem inseridos em um contexto de ampla hegemonia de um sistema que favorece a heteronomia e de relações mercantis evidencia alguns limites da autogestão. Determinadas perspectivas do trabalho profissional deslocam a atividade produtiva para uma atividade que envolve cada vez mais saberes especializados, que se inseri numa cultura cada vez mais técnica e numa complexa divisão macro-social de tarefas (LISBOA, 2005). Nesta perspectiva, esboça-se a certeza de que algum traço de alienação está inscrita de maneira irreversível nas forças produtivas, chegando à hipótese de que "sempre permanecerá uma dimensão de heteronomia, inclusive nas atividades produtivas autônomas, pois estarão predeterminadas por um sistema, não podendo ser livremente estabelecidas".

Os EES, longe de suas redes de cooperação, se desenvolvem diante de um sistema que não favorece a autogestão, no entanto, é necessário compreender a autogestão como processo educativo e contínuo. Neste processo, construído socialmente, são evidenciados potenciais educativos 
ressaltados por Singer (2001), desta forma, a autogestão, através das práticas que a envolvem, permitiria educar e transformar o comportamento dos sujeitos, no sentido de que suas ações passassem a ser pautadas por valores ideológicos que não aqueles das relações sociais capitalistas. Portanto, para Paul Singer, a constituição de empreendimentos autogeridos não seria apenas uma alternativa encontrada pelos trabalhadores ao assalariamento e à pobreza, mas um conjunto de práticas que podem transformar a consciência e o comportamento dos seus praticantes, fazendo com que esses últimos incorporem valores ideológicos (participação, igualdade, solidariedade, etc.) opostos àqueles que fundamentam a lógica individual e competitiva das sociedades capitalistas. Sobre este aspecto da autogestão Singer (2002) aborda

A autogestão tem como mérito principal não a eficiência econômica (necessária em si), mas 0 desenvolvimento humano que proporciona aos praticantes. Participar das discussões e de decisões do coletivo, ao qual se está associado, educa e conscientiza, tornando a pessoa mais realizada, autoconfiante e segura.(SINGER, 2002, p.21)

Almeida et al. (2004, p. 174) ressaltam a importância da prática da participação na construção da autogestão como processo.

[...] a prática participativa, para ser efetiva, implica necessariamente processos contínuos e cumulativos de sociabilização, de produção de sociabilidades, de educação reflexiva e emancipadora; significa, ainda, a posse de informações cada vez mais amplas, totalizadoras e complexas e, sobretudo, a capacidade que adquirem os sujeitos neste processo, de produzirem ou induzirem campos de conflitos capazes de gerar ou inventar novos valores, códigos, práticas e direitos para si e toda a sociedade (idem).

Compartilhamos das premissas construídas pelos autores sobre a autonomia constituida no âmbito dos EESs.

Assim como se entende participação como conquista, o mesmo se pensa sobrre autonomia, pois esta é antes de tudo autodeterminação, autogoverno. Nesta medida, não pode ser vista de outra forma a não ser como exercício de liberdade e de capacidade de ação dotada de vontade intencional. Entretanto, quando se trata de empresa solidária, não é possível imaginar um sujeito autônomo, independente do grupo do qual faz parte; a este conceito é necessário incorporar o de solidariedade, como valor que rege a lógica da relação dos diferentes sujeitos que , ao viverem juntos, produzem a empresa solidária (ALMEIDA et al., 2004, p. 174).

Desta forma, um dos grandes desafios colocados aos EESs é a construção de autonomia coletiva em detrimento de condutas individualistas.

\subsubsection{Caracterização dos princípios para a autogestão}

A literatura e os casos descritos sobre o tema nos fornecem elementos importantes para identificarmos as variáveis que interferem em alguma medida no grau de autogestão, ou ainda, importante para examinarmos o processo de transição para autogestão. Desta forma, estes estudos 
contribuem para o exame da transição para a autogestão na prática da Marcenaria Coletiva de Mulheres. Os fatores identificados neste processo foram:

a) Posse ou controle coletivo dos meios de produção: trataremos da posse ou controle coletivo dos meios como sendo os elementos do processo protutivo utilizados para transformar a natureza como: máquinas, equipamentos, ferramentas, infraestrutura (edificação e suas instalações), insumos e matérias-primas (SINGER, 2002; NASCIMENTO, 2003; ALMEIDA et al, 2004; ICAZA, 2004);

b) Constituicão de um fundo coletivo: será tratado como fundo coletivo os recursos financeiros destinados a sanar as necessidades do empreendimento com relação a: atividades educacionais, acesso a direitos do trabalhado e da trabalhadora (como saúde, férias remuneradas, aposentadoria, etc.), aquisição, manutenção ou melhoria dos meios de produção. Sobre este ponto percebeu-se lacunas na literatura que tratassem da organização de fundos por iniciativas econômicas solidárias informais, desta forma, as bases para definição de fundo as práticas cooperativistas que possuem marcos regulatório sobre a formação de fundos obrigatórios e sociais;

c) Participacão direta no processo decisório: em casos de empreendimentos nos quais 0 número de associados não é demasiado, as trocas de informações e compartilhamento das tomadas de decisões se realizam no cotidiano do funcionamento do empreendimento, caso contrário, são encontradas formas de representação nas tomadas de decisão (SINGER, 2002; NASCIMENTO, 2003; ALMEIDA et al, 2004; ICAZA, 2004, CRUZ, 2006);

d) $\quad \underline{O}$ grau de identidade do grupo de associados em torno de valores de cooperação e solidariedade no trabalho: o princípio de solidariedade serve para justificar uma forma de relação entre os pares, que leve em consideração o interesse do grupo e, assim, reconhecerse como integrante de um projeto comum e pode ser caracterizado por um maior envolvimento e uma maior participação dos integrantes no processo de gestão e produção. Podemos aferir 0 grau de solidariedade pelas maneiras de processar os $\operatorname{conflitos}^{3}$ no âmbito do empreendimento (CRUZ, 2006).

\footnotetext{
3 Os conflitos são necessários, em determinadas doses, pois podem levar às mudanças positivas no grupo, por exemplo, à medida que são superados podem fortalecer a coesão social do grupo. Por outro lado, os conflitos podem gerar situações negativas que podem acarretar em desestruturação dos laços criados e rompimento das relações estabelecidas (ETZIONI, 1980).
} 


\subsection{Relações de gênero e empoderamento nas práticas econômicas solidárias}

Entender as relações de poder nas atividades de produção e reprodução da vida é condição para aumentarmos a compreensão sobre o papel das instituições públicas no que se refere a produção de conhecimento e de tecnologia adequada a realidade socialmente construída. Contribuem para esta compreensão os estudos sobre a perspectiva de gênero e empoderamento na medida em que tratam do processo de mudança decorrente da penetração do capitalismo no campo e de seus efeitos sobre a divisão sexual do trabalho e apontam alternativas para transformação deste panorâma.

\subsubsection{A produção e a reprodução na perspectiva de gênero}

De acordo com a autora Fátima Cruz o trabalho produtivo corresponde ao trabalho valorizado socialmente, remunerado economicamente e que atribui prestígio social a quem o realiza, enquanto o reprodutivo é desenvolvido no ambiente doméstico familiar, portanto é um trabalho que se desenvolve no âmbito privado e engloba as tarefas destinadas a "reproduzir a vida cotidiana". A autora afirma que esta forma de trabalho é subvalorizada e muitas vezes passa despercebida, porém "é imprescindível para viver". Este trabalho reprodutivo historicamente está relacionado com o trabalho feminino e é, em sua maioria, individual: "a produção que se realiza neste tem um valor de uso e não um valor de troca. Não é remunerado" (CRUZ, F. 1998, p. 8). O trabalho reprodutivo é também considerado "trabalho invisível", feito não para si, mas "para os outros, sempre em nome da natureza, do amor e do dever maternal" (ANGELIN \& BERNARDI, 2007, p.1).

As afirmações acima sobre a participação das mulheres na divisão do trabalho são corroboradas pelos estudos de caso elaborados por Brumer (1988), Viera (1996) e Bergamasco (1996). Elas identificaram em suas pesquisas e exames da situação da mulher, especialmente, a residente no território rural, que na América Latina, embora a participação das mulheres varie nas diferentes sociedades no que diz respeito à sua participação na divisão do trabalho produtivo, existe muita semelhança entre elas no que se refere à sua participação nas atividades de reprodução, "tanto as ligadas ao ciclo curto (tais como o trabalho doméstico e as atividades diárias de manutenção), como as relacionadas ao ciclo longo, geracional (tais como a reprodução biológica e a educação das crianças4)".

\footnotetext{
4 Ver Beneria (1979) e Brumer (1988).
} 
A pesquisa realizada por Brumer e Giacobbo (1993) permite verificar que as diferenças registradas na participação das mulheres em atividades produtivas no meio rural decorrem de fatores tais como: mudanças nos sistemas de cultivo, formas de propriedade, introdução de novos produtos e novas tecnologias, modificações nas relações de produção e situação de classe das mulheres. Segundo Brumer e Giacobbo (1993, p.152)

[...] a mecanização da unidade de produção libera mão-de-obra, podendo então, a mulher, dedicar-se apenas às suas atividades externas. Já no caso dos estabelecimentos não mecanizados, a mulher, além do seu trabalho externo, necessita ajudar em praticamente todas as atividades da propriedade, com exceção dos casos em que a presença de parentes ou outros subsistitui o seu trabalho (idem).

Hartmann (1976) afirma, também, que a especialização, o aumento da produtividade e a complexidade da sociedade levaram a diferenciação e complementariedade de papéis entre homens e mulheres. Segundo Brumer (1988), as causas desta hierarquisação se devem a três mudanças: a) as mulheres perderam o controle dos meios de subsistência como decorrência das transformações nos métodos de produção e da desvalorização de sua participação na divisão do trabalho; b) em substituição a um trabalho de característica social e focalizado no grupo de parentesco, seu trabalho passou a ser privado e centrado na família; c) alguns homens asseguraram o seu poder sobre outros através de mecanismos de Estado, e como forma de compensação, elevaram a situação dos homens subordinados em suas famílias e utilizaram a família nuclear contra o grupo de parentesco. A autora reforça ainda, que o controle sobre as mulheres é mantido diretamente na família pelos homens, mas é ao mesmo tempo apoiado por instituições sociais como o Estado e a religião.

Brumer (1996) identificou os espaços que, predominantemente, as mulheres encontraram nas tarefas produtivas no meio rural:

a) atividades manuais relativas ao trabalho agrícola, principalmente durante a fase de colheita dos produtos;

b) atividades relacionadas ao processamento de produtos agrícolas;

c) cuidado de animais, incluindo a retirada de leite e a criação de animais pequenos destinados sobretudo ao consumo doméstico;

d) trabalhos da horta (geralmente doméstica).

Lechat (1996, p. 103) em seus estudos de caso em dois assentamentos do Rio Grande do Sul constatou que "na lavoura a mulher é mão-de-obra de reserva para épocas de intenso trabalho, como a capina, a colheita do feijão e do milho e o plantio da mandioca, todos, serviços manuais". 
Brumer (1996, p.51) destaca em seus estudos características ou capacidades das mulheres que marcam sua posição na sociedade sugerindo que as atividades produtivas executadas por este grupo "têm em comum a exigência de algumas qualidades que supostamente as mulheres possuem (por natureza ou por aquisição, por meio do processo de socialização) ou que sua situação de trabalhadoras eventuais propicia (devido à manutenção de suas obrigações na esfera da reprodução)", tais como:

a) capacidade de executar tarefas repetitivas, tediosas e intensivas;

b) disponibilidade de envolver-se em trabalhos temporários, seja, concentrados em determinados períodos durante 0 ano, seja, envolvendo algumas horas durante o dia;

c) possibilidade de associar ao trabalho suas responsabilidades na esfera da reprodução, trazendo junto os filhos ou se afastando de suas residências por pouco tempo;

d) aceitação de uma remuneração relativamente inferior à paga a homens ou a trabalhadores envolvidos em outras atividades;

e) maior docilidade (o que implica maior aceitação das exigências do trabalho e menor número de reivindicações).

Brumer (1996, p.54) reforça que "a hieraquização entre os sexos e a atribuição preferencialmente às mulheres das atividades ligadas aà esfera da reprodução explica em grande parte a divisão sexual do trabalho produtivo".

A reconstrução do papel da mulher na estrutura de gênero é foco das transformações buscadas pela abordagem da perspectiva de gênero. $O$ entendimento desta estrutura aponta o foco de atuação e transformação alavancada por esta ferramenta.

La estructura de género consiste en el reparto de tareas y funciones sociales a partir de marcas sexuales, asignando tareas diferenciadas a hombres y a mujeres: donde la actividad productiva (visible e invisible) en la sociedad se fundamenta en una división del trabajo que se establece en función de las atribuciones de género. Tradicionalmente a los hombres se les ha asignado las tareas y responsabilidades en lo que se denomina "ámbito productivo", ligado a la producción y comercialización de bienes de consumo. Las mujeres a su vez se han convertido en responsables del "ámbito reproductivo", de las actividades domésticas, de la atención a las necesidades de mantenimiento básico de la vida, de cuidado de las personas dependientes y de atención a la vida cotidiana familiar. Ese reparto también implica el dominio de los hombres en el espacio público, la ciudadanía, la política y las actividades remuneradas, mientras que las mujeres se encuentran simbólica y materialmente restringidas al espacio privado, entre lo familiar y doméstico (CRUZ, 2006, p. 4).

Segundo Fátima Cruz (2006) esta sutil rede de mecanismos sociais que permeam as relações familiares e sociais pode ser reconstruída a partir da perspectiva de gênero que se projeta 
como ferramenta para a construção de uma sociedade participativa e inclusiva. De acordo com a autora aplicar a perspectiva de gênero implica em mulheres e homens nos processos de desenvolvimento. Desta forma, as relações de gênero não são sinônimos de "mulheres", mas sim, construídas com mulheres e homens afetando, portanto, a toda a sociedade e a todos os âmbitos da atividade humana.

\begin{abstract}
No es un trabajo solo con mujeres, que excluya a los hombres, sino que contempla las diferencias y los puntos de encuentro, propone la visibilización de las especificidades y potencia las sinergias y la solidaridad para la construcción de relaciones equitativas. Es un proceso de explicitar los deseos y necesidades y desvelar los mecanismos de dominación y de ocultamiento de las discriminaciones, estableciendo negociaciones y pactos, así como, fortaleciendo los vínculos de solidaridad y cooperación intra e inter-géneros. Pero hay que tener en cuenta que las negociaciones y pactos sólo son posibles cuando las diversas partes tienen recursos con los que negociar, además, son concientes de ellos y tienen capacidad para tomar decisiones con autonomía. La situación de desigualdad de poder en las relaciones entre mujeres y hombres impide que se den estas premisas, imponiendo la subordinación y la dependencia femenina (CRUZ, F. 2006, p. 2).
\end{abstract}

Assim, quando falamos relações de gênero, estamos falando de poder. Na medida em que as relações existentes entre masculino e feminino são relações desiguais, assimétricas, mantém a mulher subjugada ao homem e ao domínio patriarcal.

\title{
1.3.2 Empoderamento e as práticas econômicas solidárias
}

Em um amplo estudo sobre as definições e sobre os processos pelos quais se favorece o empoderamento de comunidades ou grupos, Oakley e Clayton (2003) sistematizaram importantes contribuições para o entendimento sobre o termo e as relações de poder. Em seus estudos ficou evidente que empoderamento é um termo complexo que não se define facilmente e que está aberto a uma variedade de interpretações. Pode-se afirmar que a base para a construção do termo está no aumento da compreensão sobre o poder e quem os possui. Para os autores, o "poder" exerce um papel dominante na determinação dos que progridem e dos que não podem fazê-lo, tanto na unidade familiar e nas relações personalizadas ("cara a cara") entre seus diferentes membros, quanto por meio de uma variedade de estruturas administrativas que regulam a vida das pessoas e 0 acesso aos recursos e oportunidades de avanço. De modo semelhante, estudos sociológicos distinguem três formas básicas de poder - social, político e econômico - e demonstram que o acesso a essas diferentes fontes pode ter um efeito benéfico na habilidade para progredir do indivíduo, da família ou do grupo.

A compreensão sobre empoderamento pressupõe aceitar que "em todo grupo social há algum grau de poder em relação ao seu ambiente imediato". Quando falamos de processo de empoderamento, nos referimos à posições relativas ao poder formal e informal desfrutado por 
diferentes grupos socioeconômicos, e às consequências dos grandes desequilíbrios na distribuição desse poder (OAKLEY; CLAYTON, 2003). Um processo de empoderamento busca intervir nestes desequilíbrios e ajudar a aumentar o poder daqueles grupos "desprovidos de poder", relativamente aos que se beneficiam do acesso e uso do poder formal e informal

Poder no sentido usado por Paulo Freire, como um aumento da conscientização e desenvolvimento de uma "faculdade crítica" entre os marginalizados e oprimidos. Este é 0 poder de "fazer" e de "ser capaz", bem como de sentir-se com mais capacidade e no controle das situações. Refere-se ao reconhecimento das capacidades de tais grupos para agir e desempenhar um papel ativo nas iniciativas de desenvolvimento. Implica superar décadas de aceitação passiva e fortalecer as habilidades de grupos marginalizados para que se envolvam como atores legítimos no desenvolvimento (OAKLEY; CLAYTON, 2003).

O poder também está relacionado com o conhecimento, o qual consiste em uma fonte de poder e em uma forma de adquirí-lo. A esse respeito, Cornwall (1992) argumenta que "todo 0 trabalho de desenvolvimento está relacionado ao controle do conhecimento" e que se os "subprivilegiados" pudessem controlar as fontes de conhecimento, as estruturas das relações de poder existentes se alterariam radicalmente. $O$ conhecimento pode oferecer legitimidade e autoridade, e sua construção e disseminação são ferramentas poderosas. O conhecimento também nos ajuda a interpretar e dar forma ao contexto em que vivemos. Mas sem ele, carecemos de poder (OCAMPO, 1996).

Enquanto o enfoque sobre o empoderamento reconhece a importância do aumento de poder das mulheres, tende a identificar o poder menos em termos de dominação sobre outros e mais em termos da capacidade das mulheres de adquirir confiança em si mesmas e se fortalecerem internamente. Isso se traduz como o direito de exercer escolhas em sua vida e de influenciar os rumos das mudanças, através da capacidade de controlar os recursos materiais e não materiais. Ao contrário dos enfoques centrados na eqüidade, não enfatiza tanto o status das mulheres em comparação com o dos homens,mas busca provocar seu empoderamento através da redistribuição do poder dentro e entre as sociedades (MOSER, 1991 apud OAKLEY; CLAYTON, 2003).

Compartilhamos a definição do empoderamento como "un proceso de creación y fortalecimiento de condiciones materiales y subjetivas, tanto personales como colectivas, que posibiliten la participación en los procesos de toma de decisiones, así como el acceso y control de recursos, por parte de los grupos sociales más vulnerables, y la toma de conciencia de su poder" (CRUZ, F. 2006).

Longwe e Clarke (1994) apud Cruz (2006) elaboraram um marco analítico denominado "Marco de Igualdad y Empoderamiento de las Mujeres" o qual estabele cinco níveis de igualdade entre as mulheres e os homens, cuja conquista mede o nível de desenvolvimento e capacitação das mulheres em qualquer área da vida econômica e social. Os cinco níveis citados se referem a: 
a) Bem estar material; b) Acesso aos meios de produção; c) A consciência de gênero; d) A participação nas decisões e e) Controle sobre os recursos e benefícios.

Stromquist (1997) categoriza os avanços engendrados pelos processos de empoderamento em componentes cognitivos, psicológicos, políticos e econômica sendo a descrição de cada componente ilustrada abaixo:

- $\quad$ componente cognitivo - refere-se a compreensão que as mulheres têm da sua subordinação assim com as causas desta em níveis micro e macro da sociedade. Envolve a compreensão de ser e a necessidade de fazer escolhas mesmo que possam ir de encontro às expectativas culturais e sociais. Este componente cognitivo do empoderamento também inclui um novo conhecimento sobre as relações e ideologias de gênero, sobre a sexualidade, os direitos legais, as dinâmicas conjugais, etc.;

- $\quad$ componente psicológico - inclui o desenvolvimento de sentimentos que as mulheres podem por em prática a nível pessoal e social para melhorar sua condição, assim como a ênfase na crença de que podem ter êxito nos seus esforços por mudanças: autoconfiança e auto-estima são fundamentais;

- $\quad$ componente político - supõe a habilidade para analisar o meio circundante em termos políticos e sociais, isto também significa a capacidade para organizar e promover mudanças sociais;

- $\quad$ componente econômico - supõe a independência econômica das mulheres, esse é um componente fundamental de apoio ao componente psicológico.

A Tabela 2 apresenta a organização dos componentes apresentados pela a autora e ilustra suas relações.

Tabela 2 - Esquema sobre o processo de empoderamento.

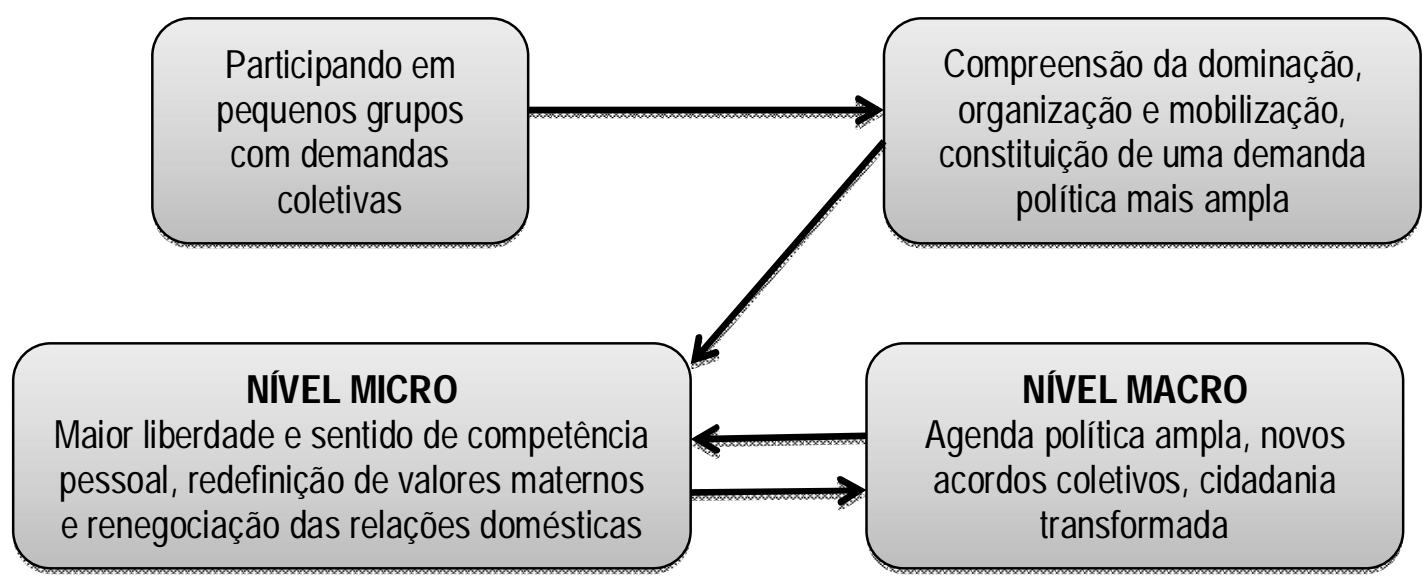

Fonte: Adaptado de STROMQUIST, 1997. 
O empoderamento das mulheres representa um desafio às relações patriarcais, em especial dentro da família, ao poder dominante do homem e a manutenção dos seus privilégios de gênero. Significa uma mudança na dominação tradicional dos homens sobre as mulheres, garantindoIhes a autonomia no que se refere ao controle dos seus corpos, da sua sexualidade, do seu direito de ir e vir, bem como um rechaço ao abuso físico e a violação sem castigo, o abandono e as decisões unilaterais masculinas que afeta a toda a família. Segundo Magdalena León (1997), o empoderamento das mulheres libera e empodera também aos homens no sentido material e psicológico, já que a mulher busca ter acesso aos recursos materiais em benefício da família e da comunidade, compartilha responsabilidades e, também, permitem novas experiências emocionais para os homens os liberando de estereótipos de gênero.

A participação das mulheres em empreendimentos econômicos solidários expõe uma relação a ser mais bem compreendida que é a possível relação de conflito entre 0 empoderamento individual e os interesses coletivos e comunitários. A intenção no âmbito da atuação da assessoria a EES é, dentre outros aspectos, conciliar os interesses individuais e coletivos garantindo 0 empoderamento individual e os vínculos coletivos e comunitários. Desta forma, o processo de incubação de EES traz semelhanças com o processo de empoderamento da mulher uma vez que ambos trazem a tona "uma nova concepção de poder, assumindo formas democráticas, construindo novos mecanismos de responsabilidades coletivas, de tomada de decisões e responsabilidades compartilhadas" (LEON, 1997).

\subsection{Atores do movimento de economia solidária e suas influências}

Segundo França Filho (2006 a) a economia solidária é um tipo de movimento social de natureza singular, precisamente em função da característica dos atores que o compõem. 0 autor considera quatro categorias de atores ou instâncias organizativas que compõem o campo da economia solidária no Brasil:

A primeira é constituída pelo que poderíamos definir como organizações de primeiro nível: os empreendimentos econômicos solidários (EES). Uma segunda categoria de atores, as organizações de segundo nível, reúne as entidades de apoio e fomento (EAF). A terceira categoria apresenta diferenças marcantes em relação às duas primeiras, por constituir-se quase que exclusivamente de formas de auto-organização política, ilustrada pelas redes e fóruns de economia solidária. Por fim, um quarto ator pode ser representado por uma espécie de nova institucionalidade pública de Estado. Dela são exemplos a rede de gestores de políticas públicas de economia solidária, a Secretaria Nacional para a Economia Solidária (Senaes), vinculada ao Ministério do Trabalho e Emprego, e, ainda, uma série de outras instâncias políticas do Estado (secretarias, diretorias ou departamentos), que estão tentando construir políticas públicas de economia solidária em governos municipais ou estaduais. (FRANÇA FILHO, 2006) 
Tabela 3 - Níveis de atuação no Movimento da Economia Solidária. NIVEL 1 Empreendimentos e Iniciativas econômicas

NÍVEL 2 Entidades de Apoio e Fomento

NÍVEL 3 Redes de Apoio político auto-organizados

NÍVEL 4 Estado (SENAES, REDE DE GESTORES, ETC.)

Fonte: Adaptado de FRANÇA FILHO, 2006

Diante desta heterogeneidade de atores apresentada no Quadro 2, 0 autor expõe uma série de outros elementos importantes que demarcam esta característica. Um dos elementos diz respeito aos propósitos das iniciativas, elemento esse que distingue particularmente um empreendimento econômico solidário (EES) de uma entidade de apoio e fomento (EAF)5. Outro diz respeito ao âmbito de atuação das práticas solidárias, permitindo distinguir a economia solidária em sub-campos como o das finanças solidárias, o do comércio justo, o das formas de economia sem dinheiro, o do cooperativismo popular ou das empresas autogeridas. Um terceiro nível de análise compreende as diferenças relativas ao grau de institucionalidade das próprias iniciativas, que permite distinguir as práticas mais consolidadas, envolvendo número significativo de pessoas e mobilizando recursos importantes, de outras iniciativas de menor porte, que beiram a informalidade e enfrentam grandes dificuldades quanto à sua sustentabilidade e quanto ao nível de renda gerado.

\subsubsection{Gestores de políticas públicas de economia solidária}

Segundo França Filho (2006) os gestores da política pública em economia solidária são representados por uma espécie de nova institucionalidade pública de Estado. Dela são exemplos a rede de gestores de políticas públicas de economia solidária, a Secretaria Nacional para a Economia Solidária (Senaes), vinculada ao Ministério do Trabalho e Emprego, e, ainda, uma série de outras

5 Como propósitos dos empreendimentos econômicos solidários temos a geração de trabalho associado e renda as populações que as adotam como meio de produção coletiva, temos as iniciativas econômicas solidárias que possuem diversos papéis como de organizar consumidores entorno do consumo ético, justo e solidário e as entidades de apoio e fomento que assumem o papel de assessores aos EES e iniciativas mas também são atores que participam dos fóruns de discussão e deliberação do movimento da economia solidária nos diversos âmbitos. 
instâncias políticas do Estado (secretarias, diretorias ou departamentos), que estão tentando construir políticas públicas de economia solidária em governos municipais ou estaduais.

Schiochet (2009), em estudo sobre a evolução das políticas públicas em economia solidária, caracteriza o contexto do surgimento das iniciativas governamentais de construção de uma agenda política-institucional para a economia solidária.

É preciso considerar também que a economia solidária entrou na agenda das políticas governamentais como que "pela porta dos fundos". Refiro-me aqui às iniciativas de cooperação econômica e autogestão surgidas no âmbito dos programas de geração de trabalho e renda. Apesar de adotarem a perspectiva da empregabilidade (responsabilização do trabalhador pelo emprego ou desemprego), volumes substantivos de recursos destes programas foram apropriados pelo movimento social e sindical para a promoção de ações de qualificação profissional e apoio a projetos de geração de renda. Programas de geração de trabalho e renda também estavam presentes nas políticas assistenciais e de desenvolvimento local. Muitos empreendimentos econômicos solidários surgiram, por exemplo, no âmbito do Programa de Desenvolvimento Local e Integrado e Sustentável (Dlis) e do Plano Nacional de Qualificação Profissional (Planfor). Os dados do Sistema Nacional de Informações em Economia Solidária (Sies) também demonstram a importância do apoio governamental (vários órgãos e instâncias) para o surgimento da economia solidária no país ao longo da década de 1990 (SCHIOCHET, 2009, p.56)

Segundo o mesmo autor, neste contexto de "experimentalismo" na construção de uma agenda governamental para a economia solidária, a disposição dos gestores foi tomando corpo e maior organicidade para a troca de informações e experiências. Neste sentido, a constituição da Rede de Gestores destas políticas permitiu um salto de qualidade para o debate e as práticas das agora denominadas "políticas públicas de economia solidária". Isto porque a iniciativa dos gestores de dialogarem entre si, trocarem experiências, saber o que estava sendo implementado nos municípios e estados e realizar avaliações críticas foi consolidando uma compreensão de que havia unidade na diversidade. A Rede de Gestores foi fundamental para construir um processo de identidade do que se entende hoje por política pública de economia solidária6.

A realização de processos mais sistemáticos de oficinas e atividades formativas de gestores - ampliadas com o apoio da Secretaria Nacional de Economia Solidária - permitiram a sistematização de documentos e declarações sobre os princípios, as diretrizes, as características, os instrumentos e a institucionalidade das políticas públicas de economia solidária. Tal acúmulo de práticas e reflexões foi fundamental para a elaboração do textobase da Primeira Conferência Nacional de Economia Solidária em 2006 (I Conaes). Com as deliberações da conferência, as políticas públicas de economia solidária passaram, de forma definitiva, a compor a centralidade da estratégia política do movimento de economia solidária no país.

\footnotetext{
${ }^{6}$ Para aprofundar um pouco mais a problemática da institucionalização das políticas de economia solidária e seu caráter de transversalidade consultar SCHIOCHET, V. Institucionalização das políticas públicas de economia solidária: breve trajetória e desafios. In: Mercado de Trabalho: conjuntura e análise. Brasília: MTE/Ipea, n. 40, p. 55-59, agosto de 2009
} 
A própria conferência e, em especial, a criação da Secretaria Nacional de Economia Solidária - e ainda, posteriormente, a criação do Conselho Nacional de Economia Solidária configuram uma nova institucionalidade no Brasil para as políticas de economia solidária. (SCHIOCHET, 2009, p.57)

Há vários relatos da forte intervenção de outro ator público no cenário das políticas de economia solidária: o Ministério Público. É necessário avançar nos estudos relacionados ao papel do Ministério Público na construção das políticas de economia solidária uma vez que interferem diretamente na prática das iniciativas econômicas solidárias.

\subsubsection{As entidades de apoio e fomento}

As incubadoras de cooperativas populares (ITCPS), entidades de apoio e fomento, surgem na perspectiva de redefinição do papel das universidades e da indissociabilidade entre pesquisa, ensino e extensão.

Em 1987 o Fórum Nacional de Pró-Reitores de Extensão redefiniu a concepção de extensão que em documento oficial passou a ser definida como "processo educativo que articula 0 ensino e a pesquisa de forma indissociável e que torna viável a relação transformadora entre universidade e sociedade". No entanto, se constitui como tarefa mais difícil que a conceituação, o processo de transformação da cultura universitária, pois a extensão na prática continua pontual, volátil e desconectada da realidade social. (DUBEUX, 2007).

A concepção de extensão elaborada pelo Fórum de Pró-reitores é a que exatamente parece influenciar a criação das Incubadoras Tecnológicas de Cooperativas Populares que serão apresentadas a seguir.

O papel da Universidade na consolidação da Economia Solidária como estratégia de Desenvolvimento na abordagem territorial tem como ator importante as Incubadoras Tecnológicas de Cooperativas Populares (ITCPs) que surgem em meados da década de 1990.

De acordo com Dubeux (2007), a extensão realizada pelas ITCPs é diferenciada sob vários aspectos como a duração e continuidade no acompanhamento dos grupos e o caráter inovador de produção de tecnologias mais apropriadas para classes sociais mais desfavorecidas. As ITCPS inauguraram uma nova época na universidade brasileira como importante programa de extensão universitária entrelaçado com atividades de ensino e pesquisa.

As incubadoras de base tecnológica influenciaram 0 surgimento da primeira experiência de ITCP no que se refere à relação com a universidade e com a produção de inovação. Esta experiência aconteceu na Universidade Federal do Rio de Janeiro (UFRJ), em 1995, fruto de uma 
articulação entre o Comitê de Entidades Públicas no Combate à Fome e pela Vida (criado pelo Sociólogo Betinho), a Fundação Oswaldo Cruz, a Coordenação dos Programas de Pós-Graduação em Engenharia (COPPE) da UFRJ, Fundação Banco do Brasil (FBB) e da Financiadora de Estudos e Projetos (FINEP). Por ter surgido em um centro tecnológico de ciências exatas, é de se esperar que não se encontrasse profissionais capazes de avançar com um projeto de dimensão social como este. No entanto, ocorreu o contrário devido a alto grau de engajamento em ações sociais por parte do grupo da engenharia de produção da COPPE ligados a produção de tecnologias alternativas. A equipe envolvida com o início da incubadora, apesar do engajamento político, não detinha conhecimento acerca da gestão de cooperativas e não tinham como recorrer a algum modelo por serem pioneiros em incubação de cooperativas populares. Esta equipe criou o primeiro modelo de método de incubação que foi rapidamente difundido e compreendido como ferramenta política necessária a manutenção de experiências como esta.

Em seguida, no âmbito do governo federal, ocorre a criação do Programa Nacional de Incubadoras Tecnológicas de Cooperativas Populares (PRONINC) com intuito de criar ITCPs em outros estados. Atualmente existem mais de 70 ITCPs que organizam em duas redes: a rede de ITCPs e a Fundação UNITRABALHO. O objeto de estudo desta dissertação, uma ITCP que será ainda apresentada, faz parte da rede de ITCPS (SERRANO, 2008).

Durante cerca de 10 anos, as ITCPs aperfeiçoaram o chamado método de incubação, contribuindo para consolidação dos EES, para a produção de conhecimento na área e para educação dos diversos atores envolvidos. Entretanto, mais importante é o fato das incubadoras terem ampliado seu escopo de atuação, deixando de atuar somente no campo do cooperativismo e passando a discutir a economia solidária mais amplamente. A partir de então, as ITCPs passam a incubar redes, grupos informais, associações etc., a trabalhar com perspectiva multidimensional, incorpora a perspectiva do desenvolvimento local. Os obstáculos que se pode destacar na atuação das incubadoras são semelhantes aos enfrentados pela extensão universitária: a conceituação, a institucionalização e 0 financiamento (DUBEUX, 2007).

\subsubsection{Empreendimentos econômicos solidários}

Como ferramenta que tem servido atualmente para se referir aos diversos tipos de experiências de economia solidária, os empreendimentos econômicos solidários (EESs) instituem modalidades de trabalho às quais ocorrem indivíduos que vivem ordinariamente do emprego da sua força de trabalho. Os EES se dão nas esferas da produção, da distribuição, do consumo, da poupança 
e do crédito e podem tomar a forma de cooperativas, associações, clubes de trocas, empresas autogestionárias, fundos rotativos, etc. (SINGER, 2004).

Cruz (2006) define EES como:

[...] o conjunto das iniciativas econômicas associativas nas quais (a) o trabalho, (b) a propriedade de seus meios de operação (de produção, de consumo, de crédito, etc.), (c) os resultados econômicos do empreendimento, (d) os conhecimentos acerca de seu funcionamento e (e) o poder de decisão sobre as questões a ele referentes são compartilhados por todos aqueles que dele participam diretamente, buscando-se relações de igualdade e de solidariedade entre seus partícipes (CRUZ, 2006).

Os princípios que, em proporção variável, são adotados por estes empreendimentos são: arranjos coletivos na posse dos meios de produção, no processo de trabalho e na gestão do empreendimento, minimizando a presença de relações assalariadas (GAIGER, 2003). As relações sociais de produção desenvolvidas no âmbito dos empreendimentos econômicos solidários apontam para uma forma alternativa de desenvolvimento da sociedade, pois modificam o princípio e a finalidade da extração do trabalho excedente onde: a) funcionam com base na propriedade social dos meios de produção, vedando a apropriação individual desses meios ou sua alienação particular; b) o controle do empreendimento e o poder de decisão pertencem à sociedade de trabalhadores, em regime de paridade de direitos; c) a gestão do empreendimento está presa à comunidade de trabalho, que organiza o processo produtivo, opera as estratégias econômicas e dispõe sobre o destino do excedente produzido (VERANO, 2001). Em suma, há uma unidade entre a posse e o uso dos meios de produção onde as relações sociais de produção desenvolvidas nos EESs se distinguem da forma assalariada. Neste contexto, esta dissertação caracterizará a prática da autogestão em um empreendimento econômico solidário onde as decisões de o que produzir, como produzir, para quem produzir e como gestar a produção e organização dos processos estão nas mãos dos trabalhadores e trabalhadoras.

Acrescenta Oliveira (2004) a definição de EES como atores que, de fato, "expressam um processo de construção de espaços diferenciados para o desenvolvimento de atividades produtivas, bem como de outras relacionadas ao mundo dos homens".

\subsection{Incubação de empreendimentos econômicos solidários como processo educativo}

A reflexão sobre o papel da economia solidária e mais especificamente, da tecnologia, perpassa a revisão do papel das instituições de ensino e pesquisa tomando desta maneira como objeto a relação entre as instituições e as organizações na sua ligação ativa, operacional, funcional e instrumental, na conexão circular com os aspectos concretos dos produtos, processos, meios e 
artefatos (BOCAYUVA, 2009). Segundo mesmo autor, o que está em questão é a possibilidade de pensarmos múltiplos atores e cenários de construção de uma estratégia onde se valorize a autonomia do trabalho.

Configuram-se como sujeitos importantes da construção desta proposta alternativa de desenvolvimento as incubadoras tecnológicas de cooperativas populares (ITCPs). Em 1997, as ITCPS, emergem como força relevante na perspectiva de ação sociopolítica inovadora em contraposição às condutas empresariais que, por tradicionais ou modernas, demonstram ser refratárias à qualquer processo de absorção da força de trabalho que preserve e amplie a dignidade e a cidadania do trabalhador. Atualmente, em graus variados, as ITCPs realizam intervenções por meio da incubação de EESs na perspectiva de geração de trabalho associado, renda e acesso a cidadania para segmentos historicamente excluídos da população, simultaneamente a sistematização dos dados e informações para a produção, uso e difusão de conhecimento e tecnologia como forma de subsidiar as ações dos EESs e da própria incubadora com a formação dos envolvidos no processo (CORTEGOSO et al. 2010).

Gradativamente surgem políticas e ações de estímulo à criação de EES: micro-crédito, formação em empreendimentos cooperativos, incubadoras tecnológicas de cooperativas populares (ITCPS) e outros. Essas incubadoras, especialmente as inseridas nas universidades públicas, criam condições institucionais e motivacionais para esses empreendimentos na contramão do que se verifica normalmente nas universidades. Como salienta Singer ${ }^{7}$ em entrevista concedida em 2007

[...] a universidade normalmente tende a se concentrar nos futuros empregadores dos seus estudantes. Esse é o público para o qual a universidade tende a dar atenção, é o chamado mercado. Mas é preciso considerar que uma grande parte da população não está nesse mercado e não tem dinheiro. Então, as incubadoras de certa forma estendem o interesse, a curiosidade, a atividade de pesquisa das universidades ao universo dos excluídos. (OLIVEIRA, 2007)

No caso mais específico das ITCPs é apresentado um desafio importante: como desenvolver instrumentos de gestão cotidiana, as condições objetivas - técnicas, administrativas e econômicas - da autogestão de maneira participativa com os membros do próprio empreendimento?

7 ECONOMIA SOLIDÁRIA foi o tema central da entrevista concedida por Paul Singer, professor aposentado da Faculdade de Economia e Administração da USP e titular da Secretaria Nacional de Economia Solidária, órgão vinculado ao Ministério do Trabalho e Emprego, a Paulo de Salles Oliveira, professor do Departamento de Psicologia Social e do Trabalho do Instituto de Psicologia da USP, e autor de Cultura solidária em cooperativas. Projetos coletivos de mudança de vida (São Paulo, Edusp/Fapesp, 2006), no dia 23 de setembro de 2007. 
Bocayuva (2001) em relato sobre a atuação de uma das primeiras ITCPs do Brasil, Incubadora Tecnológica de Cooperativas Populares (COPPE/UFRJ), apresenta a importância da incubação para os EES e quais as frentes de atuação necessárias param o sucesso destas iniciativas.

O sucesso das cooperativas depende de seu processo de incubação. Esse processo, que trata do cooperativismo popular, merece um cuidado especial das incubadoras universitárias. Trata-se de apoiar a construção associativa e legal-formal, o acesso ao mercado, a elaboração de projetos, a definição de processo e produto, o acompanhamento e a capacitação gerencial, a administração, o planejamento, a controladoria, a contabilidade e outras áreas necessárias ao sucesso do empreendimento. Isso tudo sendo realizado numa perspectiva de longa duração e apoiado numa estratégia de construção de alianças, de mudança de ambiente e na obtenção de recursos materiais e técnicos (BOCAYUVA, 2001).

Algumas ITCPs apresentam no âmbito de sua ação a prática contínua e permanente de construção de conhecimento que segundo CORTEGOSO (2004) tem

[...] o intuíto de construir mecanismos de aproximação da população excluída, tanto em busca de melhor conhecer as necessidades e saberes desta população, quanto para transformar conhecimento produzido no âmbito da universidade em comportamentos humanos, em realidade social (CORTEGOSO, 2004).

De acordo com a autora estes "mecanismos de aproximação" podem se configurar em métodos de incubação que se pretendem

[...] capazes de viabilizar não apenas a existência de coletivos organizados para o trabalho, mas seu funcionamento como células efetivamente autogestionários e comprometidas com os princípios orientadores da economia solidária, além da inserção destas células em complexas redes de relações que envolvem outros empreendimentos solidários, outros atores sociais da economia solidária e mesmo no mercado capitalista, menos amistoso a esta forma de organização do trabalho e gestão (CORTEGOSO, 2004).

Para Dagnino e Fonseca (2007) a incubação prepara constituição de empreendimentos solidários autogestionários, onde os trabalhadores são donos, planejadores e executores do processo produtivo e dos meios de produção. Desta forma, como ressalta Oliveira $(2004$, p. 336) os processos de incubação se caracterizam como processos educativos nos quais

[...] os princípios que expressam o significado de economia solidária deverão sempre orientar os processos educativos de natureza técnica, política e cultural que vierem a se organizar para o desenvolvimento dos empreendimentos econômicos autogestionários. $\mathrm{E}$ mais ainda, diante da necessidade de extrapolar os limites do empreendimento, é crucial que estes processos se desenvolvam com um forte conteúdo de crítica ao modo de produzir e de distribuir típicos da sociedade capitalista. A expectativa é que assim seja possível a responsabilidade social na direção de questões mais gerais (econômicas, sociais e ambientais) dos envolvidos nesta construção social.... O objetivo, portanto, é mostrar para 0 conjunto da sociedade a possibilidade de transformar indivíduos associados em "produtores socialmente conscientes e livremente associados" (idem). 
Nota-se, portanto, que os processos de incubação são elementos importantes para 0 exame das relações pretendidas no âmbito das práticas econômicas solidárias. Contudo, faz-se necessário a caracterização desta prática e aprofundamento de formas de atuação destas incubadoras.

\subsubsection{Práticas de incubação das ITCPs}

No Brasil atualmente contamos com a atuação de dezenas de ITCPs em universidades públicas e privadas que integram as duas redes de incubadoras: a UNITRABALHO e a Rede de ITCPS. As redes de incubadoras surgem na década de 1990 no âmbito do debate sobre a indissociabilidade do ensino, da pesquisa e da extensão nas univesidades. Este princípio no âmbito das incubadoras perpassa a ação na realidade, com 0 aprendizado de todos os envolvidos no processo com a sistematização permanente desta ação.

A incubação de cooperativas seria, de um lado, um trabalho educativo de pessoas marginalizadas e empobrecidas; de outro, um apoio constante à atividade econômica das cooperativas, de caráter tecnológico, mercadológico, gerencial, financeiro e jurídico. Como 0 espectro de atividades produtivas que seriam desenvolvidas pelas cooperativas não era previsível, era lógico procurar recrutar pessoas de todas as áreas da universidade (SINGER, 2002)

Segundo Gonçalo Guimarães, coordenador da Incubadora Tecnológica de Cooperativas Populares da COPPE/UFRJ e Coordenador Nacional da Rede Universitária de Incubadoras Tecnológicas de Cooperativas Populares:

O projeto da Incubadora é, hoje, uma vertente de extensão das universidades públicas brasileiras. Iniciado em meados da década de 1990, na COPPE/UFRJ, encontra-se implantado em treze universidades, distribuídas em parte significativa do território nacional. Essas universidades estão estruturadas sob forma de Rede, num programa da Fundação UNITRABALHO, que reúne 78 universidades brasileiras, envolvendo grupos ligados especificamente à área do trabalho ${ }^{8}$ (GUIMARÂES, 2001).

As incubadoras, neste sentido, representam um impulso na transformação das práticas de extensão universitária, recortada na direção de setores populares excluídos social, econômica e cultural. Este impulso transformador é engendrado pela articulação multidisciplinar de áreas de conhecimento constituídas no âmbito acadêmico e popular. Esta interação é desenvolvida a partir de métodos de incubação.

No âmbito do movimento de economia solidária há um claro processo de geminação de métodos de incubação que conta com o acúmulo das ITCPs. Há distintos métodos utilizados pelas

8 [1] Trecho recortado do livro Redução da Pobreza e Dinâmicas Locais / organizadores Ilka Camarotti e Peter Spink. Rio de Janeiro: editora FGV, 2001. 328p. (Coleção FGV Prática). 
ITCPS. Alguns tratam a incubação em etapas como: a) Pré-incubação, incubação e desincubação ou b)Sensibilização, Diagnóstico, Formação e Acompanhamento Sistêmico. Há neste rol de diversidade as ITCPs que são orientados por referenciais teóricos-metodológicos distintos dos que adotam etapas prédefinidas ${ }^{9}$. No seminário de avaliação do PRONINC ${ }^{10}$ em 2010 foi comum a fala de que "é necessário torná-los (os métodos) explícitos para termos bases largas para discutí-los". Ao longo do seminário foi possível identificar que há princípios recorrentes na forma de ação da maioria das ITCPs. Podemos citar: a) Formação continuada; b) Interação horizontal; c) Produção e troca de conhecimentos; d) Educação popular (aprendizagem mútua); e) Autogestão; f) Acompanhamento constante dos grupos; g) ação-reflexão-ação; h) Interdisciplinaridade; i) Trocas de saberes; j) intercâmbio entre ITCPs; h) Indissociação ensino-pesquisa-extensão. Apontou-se a necessidade de refletir em que medida a universidade e os agentes educadores estão preparados; formação e estímulo de redes de ES; dificuldades de diálogo no sentido metodológico para o desenvolvimento interdisciplinar e multidisciplinar.

\subsubsection{Método de incubação da INCOOP UFSCar}

A economia solidária, a incubação de empreendimentos coletivos autogestionários e a própria formação de incubadoras, são processos ainda em construção, de forma que a análise e aperfeiçoamento de suas dinâmicas internas são necessidades constantes. Neste contexto, 0 processamento e incorporação do método de incubação da incubadora Regional de Cooperativas Populares da Universidade Federal de São Carlos (INCOOP UFSCar), atual Núcleo Multidisciplinar e Integrado de Estudos, Formação e Intervenção em Economia Solidária (NuMI-EcoSol), pelo conjunto de sua equipe, inclusive de incubação da Marcenaria Coletiva de Mulheres, têm sido realizado de maneira não menos complexa que o próprio desenvolvimento da economia solidária, evidenciando avanços, mas também limites e contradições inerentes à sua conjuntura.

Contribui para o método de incubação da INCOOP UFSCar a noção de Análise do Comportamento que segundo Botomé (2006)

A Análise do Comportamento - em suas várias modalidades de trabalho - parece ser uma rica fonte para desenvolver esse conhecimento e essa tecnologia. Relacionar conhecimento

\footnotetext{
9 Ver próximo tópico método de incubação INCOOP UFSCar.

10 Nos dias 29 e 31 de março de 2010, aconteceu em Brasília, o Seminário Nacional de Avaliação do Programa Nacional de Incubadoras Tecnológicas de Cooperativas Populares - PRONINC. Entre os objetivos do seminário foram: contribuir para a proposta metodológica da avaliação do PRONINC em suas três dimensões - gestão do Programa, desempenho das Incubadoras e desempenho dos Empreendimentos incubados - e refletir sobre a incubação de empreendimentos econômicos solidários, considerando a visão e especificidades dos empreendimentos, das incubadoras e das entidades financiadoras e apoiadoras.
} 
e comportamento é uma complexa modalidade de comportamento que envolve descobrir e caracterizar processos comportamentais (existentes, necessários ou possíveis) como condição para a descoberta e a invenção (em graus variados de combinação) de procedimentos (tecnologia comportamental) que constituem formas de lidar com as circunstâncias com as quais as pessoas se defrontam (BOTOMÉ, 2006).

De acordo com este conceito, sistematizado por Botomé (1981), entre outros, o comportamento, como unidade de análise significativa do fazer humano, não se refere apenas ao que um organismo faz, mas à relação entre a ação do organismo e o ambiente em que a ação ocorre, em termos de condições antecedentes a esta ação (que sinalizam ser esta oportuna, necessária ou desejável, bem como aquelas que são necessárias para que a ação ocorra com as propriedades desejáveis, ou com que o organismo deve entrar em contato ao agir ou, ainda, levar em consideração) e as condições subsequentes a esta ação, em termos de resultados, produtos e efeitos da ação, e que a definem em sua funcionalidade (NuMI-EcoSol, 2013).

Assim, o método de incubação

É expresso em termos das ações que constituem os núcleos destes comportamentos, bem como de indicações sobre diante de que estas ações são desejáveis ou necessárias, aspectos que devem ser levados em conta para apresentar estas ações, os resultados, produtos ou efeitos desejáveis destas ações e propriedades delas que podem, com maior probabilidade, levar a estes resultados" (CORTEGOSO, 2004).

Em uma de suas últimas atualizações, incubar, no âmbito da INCOOP UFSCar, tem sido entendido como:

- $\quad$ Assessorar grupos para formação de empreendimentos econômicos solidários (por meio da oferta de subsídios e de acompanhamento do processo de tomada de decisão e implementação de atividades, com participação dos responsáveis pela incubação em todas as etapas do trabalho, incluindo avaliação de resultados, por meio de relações dialógicas).

- $\quad$ Algo que deve ser feito diante de demandas compatíveis com critérios em vigor na INCOOP para incubação de empreendimentos solidários, e considerando disponibilidade de recursos considerados necessários para isto.

- $\quad$ E de modo a alcançar, como resultado de sua atuação empreendimentos solidários e autogestionários de natureza popular, organizados para o trabalho coletivo, articulados com outros empreendimentos e iniciativas de Economia Solidária de todas as formas possíveis, comprometidos com desenvolvimento do território em que se insere, com capacidade crescente de funcionar em consonância com princípios de economia solidária, de identificar e providenciar 0 atendimento às necessidades do empreendimento e dos indivíduos que os 
compõem, de garantir sua sustentabilidade nas diferentes dimensões desejáveis (econômica, social, ambiental etc), de utilizar e produzir conhecimento e tecnologia compatíveis com suas necessidades e recursos e de participar de iniciativas e do movimento da Economia Solidária em todas as esferas. ${ }^{11}$

\section{No âmbito da INCOOP UFSCar}

A indicação das classes de comportamentos componentes ou conjunto de ações do processo de incubação não significa que, em todos os processos de incubação, todos estejam ou devam estar presentes, nem tampouco que sejam ou devam ser apresentados sucessivamente. Neste sentido, sua descrição completa é necessária para que seja possível proceder, a partir dele, ao exame das condições específicas de incubação de cada grupo, e à conseqüente adaptação da atuação dos incubadores a estas condições, sem perder de vista aspectos essenciais do processo de incubação (CORTEGOSO et al. 2006).

NaTabela 4 são apresentadas, em sua atualização mais recente, as classes de comportamento que integram o comportamento mais geral da INCOOP relacionado a "incubar empreendimentos solidários.

Tabela 4 - Classes de comportamento que constituem o método de incubação da INCOOP UFSCar

\section{Comportamento geral da INCOOP: Incubar empreendimentos solidários}

Diante de demandas compatíveis com critérios em vigor na INCOOP para incubação de empreendimentos solidários, e considerando disponibilidade de recursos considerados necessários para isto, assessorar grupos para formação de empreendimentos econômicos solidários (por meio da oferta de subsídios e de acompanhamento do processo de tomada de decisão e implementação de atividades, com participação dos responsáveis pela incubação em todas as etapas do trabalho, incluindo avaliação de resultados, por meio de relações dialógicas), de modo a alcançar, como resultado de sua atuação: existência e consolidação de empreendimentos solidários e autogestionários de natureza popular, organizados para o trabalho coletivo, que funcionem de forma autônoma, com capacidade para identificar suas próprias necessidades e providenciar para que sejam atendidas, inseridos no mercado e no contexto mais amplo da economia solidária e com características gradualmente mais compatíveis com princípios de economia solidária.

\section{Comportamentos mais específicos que constituem o método de incubação da INCOOP}

1. Processar demandas apresentadas por diferentes atores sociais para incubação de empreendimentos solidários;

2. Identificar população em potencial para formação de empreendimento solidário;

3. Caracterizar diferentes envolvidos no processo de incubação;

4. Apresentar a Economia Solidária como possibilidade de organização para geração de trabalho e renda, a INCOOP e sua proposta de trabalho em Economia Solidária

5. Apoiar a organização inicial do grupo para tomada de decisões a respeito de formação de empreendimento solidário e

${ }^{11}$ Como explicitado, o método de incubação da INCOOP é revisado e avaliado contínua e permanentemente por indíviduos e coletivos que atuam na equipe os quais são orientados por sua prática no conjunto das atividades com os grupos incubados. Esta apresentação do método de incubação da INCOOP assim como as classes de comportamentos consideradas podem e devem sofrer alterações, sendo esta versão apresentada relacionada a revisão realizada no segundo semestre do ano de 2011. 
suas características gerais

6. Elaborar proposta de trabalho, em conjunto com participantes do grupo a ser incubado;

7. Assessorar o grupo para escolha de atividade econômica;

8. Promover formação contínua e permanente dos membros do grupo em Economia Solidária de todas as maneiras possíveis

9. Promover formação contínua e permanente dos membros do grupo para autogestão;

10. Promover condições para capacitação técnica contínua e permanente para o serviço/produção ofertado pelo empreendimento

11. Promover elaboração participativa de normas de funcionamento do empreendimento;

12. Assessorar grupo para legalização do empreendimento;

13. Assessorar grupo para implantação do empreendimento;

14. Assessorar grupo para implantação de sistema de monitoramento por meio de indicadores;

15. Assessorar grupo esporadicamente para implementação do empreendimento;

16. Assessorar grupo para participação em redes de cooperação e em iniciativas do movimento de Economia Solidária;

17. Assessorar o grupo incubado para lidar com processos de produção e uso de conhecimento e tecnologia;

18. Assessorar o grupo para construir e manter parcerias;

19. Promover condições favorecedoras para que agentes e agências sociais com atuação ou inserção em território em que estejam inseridos empreendimentos e iniciativas solidárias estabeleçam parcerias com estes empreendimentos e iniciativas;

20. Assessorar empreendimentos para a adoção de práticas de consumo ético, solidário e responsável;

21. Assessorar empreendimentos para comercializar seus produtos e serviços e

22. Assessorar empreendimentos para planejar e aplicar estratégias de divulgação.

Fonte: Documento interno NuMl-EcoSol, 2013.

Para cada uma das 22 classes de comportamento a equipe da INCOOP UFSCar discorreu sobre seus componentes:

a) em que situações as classes de comportamento ocorrem ou deveriam ocorrer;

b) o que a incubadora leva ou deveria levar em consideração;

c) o que é esperado como resultado desta ação da incubadora e

d) como a Incubadora atua ou deveria atuar para assessorar grupo para lidar com os processos envolvidos na classe de comportamento.

Em atualização mais recente do método interessa ressaltar os componentes da classe de comportamento relacionada a "lidar com processos de produção, uso e disseminação de conhecimento e tecnologia" uma vez que oferece referências importantes para exame do caso presente nesta pesquisa. 
Tabela 5 - Classe de comportamento assessorar o grupo incubado para lidar com processos de produção, uso e disseminação de conhecimento e tecnologia.

ASSESSORAR O GRUPO INCUBADO PARA LIDAR COM PROCESSOS DE PRODUÇÃO, USO E DISSEMINAÇÃO DE CONHECIMENTO E TECNOLOGIA

\section{Em que situações ocorre, ou deveria ocorrer?}

Situações enfrentadas pelo grupo que requeiram produção, uso, adaptação ou disseminação de conhecimento ou tecnologia, por ausência ou inadequação de conhecimento ou tecnologia aos princípios da Economia Solidária ou às necessidades do empreendimento; lacunas de compreensão de indivíduos participantes de empreendimentos solidários sobre fenômenos em relação aos quais há ou pode haver conhecimento sistematizado e tecnologia disponíveis, em qualquer dimensão da vida; lacunas de conhecimento de indivíduos participantes de empreendimentos solidários sobre processos de produção de tecnologia; ou qualquer tipo de situação em que haja oportunidade para aprendizagem, reflexão e construção coletivas sobre processos de uso, produção e disseminação de conhecimento e tecnologia; conhecimento já produzido pelo empreendimento que requeira ajustes, derivação de tecnologia ou divulgação.

\section{O que a Incubadora leva ou deveria levar em consideração?}

Processos e práticas de produção de conhecimento de indivíduos que compõem o grupo ou do coletivo e que fazem parte do contexto sócio-econômico-cultural em que estes indivíduos se inserem; ferramentas conceituais e práticas e organizativa para promoção das capacidades de uso, produção e disseminação de conhecimento e tecnologia12; conhecimento já produzido pelo empreendimento.

\section{O que é esperado, como resultado desta ação da Incubadora?}

Indivíduos do grupo com capacidades crescentes de buscar, refletir sobre, adaptar, apropriar-se, utilizar e produzir conhecimento e tecnologia consoantes com os princípios da Economia Solidária, capazes de responder às necessidades coletivas e individuais, de promover transformações políticas, econômicas, sociais e culturais na direção da vida em harmonia com a natureza e com a comunidade, ausência de explorações e por meio de construção coletiva de um saber-fazer que possibilite aos trabalhadores posse e controle dos meios de produção; indivíduos mais capazes de compartilhar com parceiros, com horizontalidade de relações, processos de uso, produção e disseminação de conhecimento para 0

\footnotetext{
${ }^{12}$ Por exemplo, fundamentadas no conceito de tecnologia social, incluindo capacidades para definir problemas, sistematizar conhecimento disponível, experimentar e validar alternativas;
} 
grupo e para a Economia Solidária.

\section{Como a Incubadora atua ou deveria atuar para assessorar grupo para lidar com processos de produção, uso, adaptação e disseminação de conhecimento e tecnologia}

Por meio de identificação de necessidades e demandas do grupo incubado relacionados ao uso, disseminação, adaptação e produção de conhecimento e tecnologia; análise do conhecimento e tecnologia existentes; identificação e sistematização contínua e permanente de conhecimento e tecnologia produzidos pelo empreendimento, envolvendo gradualmente os membros do grupo neste processo; construção conjunta e participativa do conhecimento e tecnologias que cumpram com as necessidades e demandas do grupo incubado. Buscar conhecimento científico para auxiliar o grupo no desenvolvimento de Tecnologia Social (TS); Promover a disseminação do conhecimento de um grupo para construção de TS; Formar redes de construção de TS.

Fonte: Documento interno NuMI-EcoSol, 2013.

Diante do exposto e de acordo com Cortegoso et. al. (2007, p.35) o método de incubação da INCOOP enfrenta o seguinte desafio

Tornar o conhecimento científico e tecnológico acessível à população historicamente excluída é um dos desafios colocado para as Universidades públicas, principalmente quanto a produção de conhecimentos que procuram questionar os modos de produção, distribuição e consumo de bens e serviços hegemônicos que enfatizam a competição, o individualismo, a degradação ambiental para outros modos que privilegiem a cooperação, a solidariedade, a autogestão, a dimensão econômica, princípios fundamentais da Economia Solidária. 0 desafio torna-se mais complexo ainda, ao produzir conhecimento científico (compreensão de conceitos e fenômenos) e tecnológico (transferência) simultaneamente a atuação na realidade social com população exclú́da e com recursos escassos (financeiros, econômicos, cognitivos etc) e ainda a formação de diferentes tipos de pessoas para mudanças de condutas significativas, na perspectiva de melhoria de condições de vida da maioria da população (idem).

As bases que orientam a atuação das ITCPs são diversas. Desta forma é necessário aprofundar na descrição e exame das práticas destes atores para possibilitar a ampliação do debate sobre ferramentas, métodos e abordagens que favorecem a atuação dos assessores no conjunto das práticas engendradas pelos empreendimentos econômicos solidários. A INCOOP tem realizado esta sistematização de forma contínua como forma privilegiada de produção e transferência de conhecimento, tanto para subsidiar o próprio trabalho da Incubadora, quanto para a continuidade de estudos e aplicações no âmbito da Economia Solidária (CORTEGOSO et al, 2007, p.35).

\section{ECONOMIA SOLIDÁRIA E ADEQUAÇÃO SOCIOTÉCNICA}

Algum tipo de tecnologia e de ciência sempre existiu em toda sociedade durante todos os períodos da história humana. Não existe ação, enquanto fenômeno natural ou social, sem certa 
mediação por técnicas, aparatos, objetos ou processos. Como garantir que os princípios da economia solidária, e dentre elas a autogestão, se consolide nesta mediação entre o "fazer" e os meios pelos quais esta ação é realizada?

Tornar sustentáveis as novas práticas econômicas e sociais na perspectiva da economia solidária perpassa o reconhecimento de que a expansão de novos conhecimentos produtos e processos derivados do progresso científico e tecnológico transformam estruturas sociais, modos de comportamento e atitudes (SALOMON et al, 2003) ou seja, o processo de produção e de consumo de tecnologias é um processo social e , como tal, condicionado pela estrutura social que o contém criando assim, novas possibilidades de permanência e de transformação da estrutura (FIGUEIREDO, 1989).

Salomon (1993) reforça a dimensão crítica da tecnologia quando a afasta de perspectivas deterministas e a aproxima de uma relação mais intrincada entre a técnica e a sociedade.

[...] as maneiras pelas quais as mudanças técnicas transformam atitudes, instituições e sociedades não podem ser reduzidas a simples relacionamento linear automático, isto é, determinista. Tecnologia é um processo social entre outros: não é uma questão de desenvolvimento técnico de um lado e desenvolvimento social do outro, como se fossem dois mundos ou processos inteiramente diferentes. A sociedade é delineada pela mudança técnica que, por sua vez, é definida pela sociedade. Concebida pelo homem, a tecnologia foge ao seu controle somente na medida que ele deseja que ela o faça. Nesse sentido, a sociedade é definida não tanto por tecnologias que seja capaz de criar, quanto por aquelas escolhidas para empregar e desenvolver em lugar de outras" (SALOMON, 1993).

No contexto da redefinição do papel da tecnologia em relação a sociedade surge 0 debate da tecnologia social (TS). Importa destacar que o debate sobre tecnologia social tem aflorado no campo dos estudos sobre Ciência, Tecnologia e Sociedade (CTS) e de acordo com a consulta à bibliografia especializada, composta principalmente por autores latino-americanos, possibilitou perceber que o conceito de tecnologia social ainda está em definição. Nesse sentido, foram verificadas várias possibilidades explicativas do conceito, porém, identificadas duas tendências predominantes que buscam elucidar o conceito de tecnologia social. A primeira tende a explicar a tecnologia social como forma de oposição à tecnologia gerada pelo sistema capitalista e a segunda tende a apresentá-la e conceituá-la como "minimizadora" dos efeitos do modo de produção capitalista. A opção por discorrer sobre essas possibilidades explicativas deve-se à percepção de que essas duas tendências oferecem maiores possibilidades de identificação das características da tecnologia social do que outros universos explicativos, aumentando a compreensão acerca do termo e não restringindo o conceito em si (JESUS, 2010, p. 15).

... o termo tecnologia social tem sido utilizado por pesquisadores, movimentos sociais, gestores públicos e diversas organizações no intuito de demarcar um campo de iniciativas que atuam segundo uma vertente crítica às visões de neutralidade e de determinismo 
tecnológico que comumente influenciam os modelos de ciência e tecnologia hegemônicos nas instituições de ensino e pesquisa. (BOCAYUVA, 2009)

A figura 1, concebida durante uma das reuniões da Rede de Tecnologia Social, ilustra o marco analítico-conceitual da TS. Segundo, Dagnino, Brandão e Novaes (2004), a TS pode ter sua construção entendida a partir da incorporação ao movimento da tecnologia alternativa (TA) algumas críticas e contribuições. Nela aparece, no centro de uma espiral que procura denotar um processo cumulativo, a visão predominante da TA nos anos 1970. À sua volta, ao longo de cada uma das seis setas que para ela convergem, os elementos que se considera importante individualizar como conformadores do marco analítico-conceitual da TS, o qual aparece representado como uma culminação de um processo em curso, de crescente complexidade e riqueza. Cada um desses elementos - crítica da TA, economia da inovação, sociologia da inovação, filosofia da tecnologia etc. encontra-se associado aos autores cuja contribuição foi considerada central e a palavras-chave que a identificam.

Uma definição de tecnologia social amplamente difundida e adotada na América Latina é a construída no âmbito da Rede de Tecnologias Sociais (RTS) na qual "tecnologia social compreende produtos, técnicas ou metodologias, reaplicáveis, desenvolvidas em interação com a comunidade e que representem efetivas soluções de transformação social" (RTS - Brasil, 2009). A tecnologia social interage no mundo da ação humana técnica na transformação da natureza, na práxis humana no mundo do trabalho e no espaço das organizações aceitando a premissa de que "podemos agir e mudar a tecnologia13".

Diante das várias alternativas disponíveis para solução dos problemas técnicos, Feenberg (2009) aponta que a "subdeterminação técnica deixa um amplo espaço para que critérios econômicos, culturais e sociais pesem sobre a decisão final entre as alternativas".

Mas como operacionalizar o conceito de TS? De acordo com Dagnino, Brandão e Novaes (2004) e Novaes (2005) exitosos processos de desenvolvimento de TS perpassam a definição de abordagem sociotécnica que oferece a fundamentação para o conceito de "adequação sociotécnica".

\footnotetext{
13 Retirado de trecho entrevista realizada em Belém do Pará, em 27 de janeiro, durante o I Fórum Mundial Ciência e Democracia, realizado como parte das atividades do Fórum Social Mundial 2009, de Feenberg sobre as premissas de Heidegger e Marcuse ao Mariconda e Molina.
} 
Sobre a abordagem teórico-conceitual Thomas (2009, p. 50-51) constitui como a

[...] integração de conceitos teóricos provenientes de diferentes enfoques disciplinares (sociologia da tecnologia, economia da mudança tecnológica, história da ciência, sociologia do conhecimento científico, análise política, filosofia da tecnologia) proporciona uma série de ferramentas analíticas úteis para o desenvolvimento de nova visão sobre as TSs:

análise sociotécnica: dinâmica de grupos de pesquisa (SHINN, 1982; LATOUR, 1989), redes tecnoeconômicas (CALLON, 1992), grupos sociais relevantes e flexibilidade interpretativa (COLLINS, 1985; PINCH e BIJKER, 1987), marco tecnológico, fusão sociotécnica, politics da pesquisacientífica e tecnológica (BIJKER, 1995), construção social de funcionamento, dinâmicas e trajetórias sociotécnicas (THOMAS, 1999 e 2001); processos de coconstrução (VERCELLI e THOMAS, 2007),adequação sociotécnica (DAGNINO et al., 2004; THOMAS, 1999 e2008 a e b);

análise crítica da tecnologia: dialética da tecnologia (FEENBERG, 2002); crítica à neutralidade e ao determinismo (DAGNINO, 2008), contexto de implicação (TULA MOLINA e GIULIANO, 2007);

análise da política: processos de tomada de decisões, processos de conformação e implementação de agendas, modelos organizacionais, modos de integração de atores externos ao processo decisório (KNORR-CETINA,1981; HOGWOOD e GUNN, 1984; HAM e HILL, 1993; ELZINGA e JAMISON, 1996);

economia da mudança tecnológica: trajetórias tecnoeconômicas (FREEMAN, 1987), trajetórias tecnológicas (DOSI, 1988), processos de aprendizagem (ARROW, 1962; ROSENBERG, 1982; LUNDVALL, 1992), relações usuário-produtor (VON HIPPEL, 1976), sistemas nacionais e locais de inovação (NELSON, 1988; LUNDVALL, 1992; AMABLE et al., 1997; (FREEMAN, 1998), learning society (CHRISTENSEN e LUNDVALL, 2004).

A adoção de abordagem sociotécnica construtivista, como matriz conceitual da abordagem, constitui uma operação fundamental para captar o modo multidimensional do objeto "TSs" (idem).

A figura 1 ilustra o processo de construção da abordagem teórico-conceitual da tecnologia social trazendo como marco desta abordagem à tecnologia apropriada (TA) e como uma de suas vertentes a abordagem sociotécnica. 


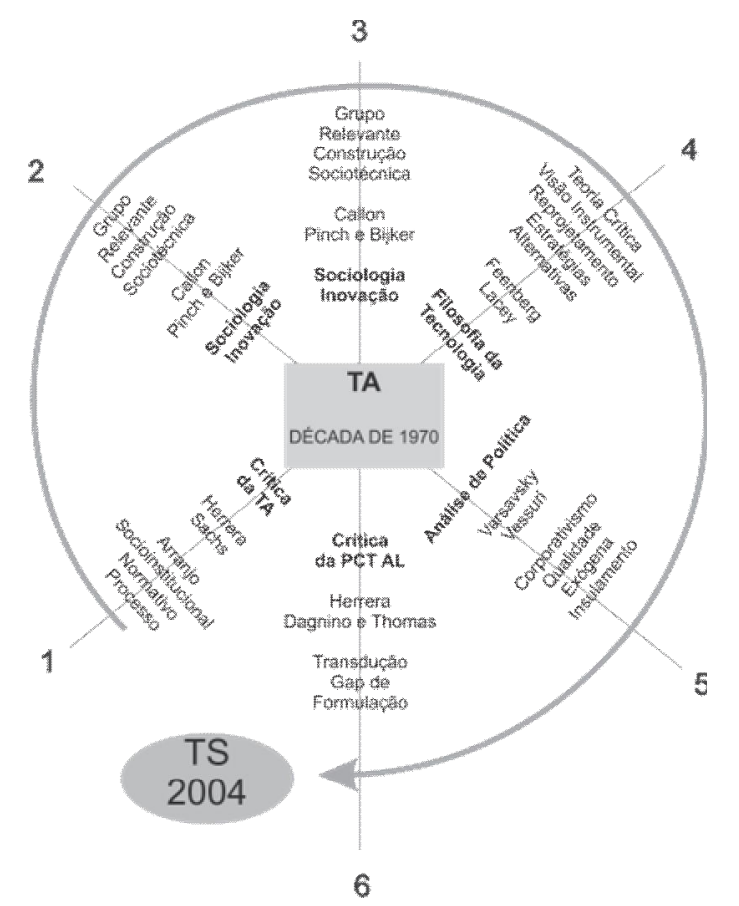

Figura 1 - Contribuição ao marco analítico-conceitual da TS.

Fonte: Dagnino, Brandão e Novaes (2004). Sobre o marco analítico-conceitual da tecnologia social, p. 4.

\subsection{A adequação sociotécnica como base tecnológica para a assessoria a empreendimentos econômicos solidários}

Como estratégia de transição de uma tecnologia reversa as necessidade da sociedade para outra que a concebe como uma construção social e, portanto um campo de batalha historicamente determinado resultante de um processo onde intervêm múltiplos atores com distintos interesses, Novaes e Dias (2009) constroem o conceito de adequação sociotécnica (AST) na qual, partindo da abordagem do construtivismo social, é entendida como um processo inverso ao da construção, em que um artefato tecnológico sofreria um processo de adequação aos interesses políticos de grupos sociais relevantes distintos daqueles que o originaram e que nessa acepção, seria um guia para a desconstrução e posterior reconstrução (ou reprojetamento) de artefatos tecnológicos, mais do que adequados, indispensáveis ao crescimento e radicalização do movimento associativista e da autogestão (cooperativas surgidas de assentamentos, mutirões dos Sem-Teto, fábricas recuperadas, cooperativas populares, etc).

Para Dagnino (2006) a AST tem significativa importância para conceber exitosos processos de desenvolvimento de tecnologias sociais na medida em que as tecnologias seriam construídas socialmente na medida em que os grupos de consumidores, os interesses políticos e 
outros similares influenciam não apenas a forma final que toma a tecnologia, mas seu conteúdo e não 0 fruto de um processo autônomo, endógeno e inexorável como concebe o determinismo.

No contexto da preocupação com os empreendimentos com características autogestionárias, 0 processo de AST teria por objetivo adequar a tecnologia convencional (e, inclusive, conceber alternativas), aplicando critérios suplementares aos técnico-econômicos usuais em processos de produção e circulação de bens e serviços em circuitos não formais, situados em áreas rurais e urbanas (como as redes de economia solidária) visando otimizar suas implicações. (NOVAES; SERAFIM; 2007, p. 72)

Nesse sentido, a AST pode ser entendida como um processo que busca promover uma adequação do conhecimento científico e tecnológico (esteja ele já incorporado em equipamentos, insumos e formas de organização da produção, ou ainda, sob a forma intangível e mesmo tácita), não apenas aos requisitos e finalidades de caráter técnico-econômico, como até agora tem sido o usual, mas ao conjunto de aspectos de natureza sócio-econômica e ambiental que constituem a relação Ciência, Tecnologia e Sociedade (DAGNINO, 2006).

Em outras palavras AST segundo Thomas (2009, p.55) é um "processo autoorganizado e interativo de integração de um conhecimento, componente ou sistema tecnológico em uma dinâmica ou trajetória sociotécnica, sócio-historicamente situada. Esses processos integram diferentes fenômenos sociotécnicos: relações problema-solução, dinâmicas de co-construção, path dependence, ressignificação de estilos tecnológicos".

Como forma de operacionalizar as definições aqui expostas sobre a AST, Dagnino e Novaes (2003) definiram sete modalidades de AST:

1) Uso: o simples uso da tecnologia (máquinas, equipamentos, formas de organização do processo de trabalho etc.) antes empregada (no caso de cooperativas que sucederam a empresas falidas), ou a adoção de tecnologia convencional, com a condição de que se altere a forma como se reparte 0 excedente gerado, é percebido como suficiente.

2) Apropriação: concebida como um processo que tem como condição a propriedade coletiva dos meios de produção (máquinas, equipamentos), implica uma ampliação do conhecimento, por parte do trabalhador, dos aspectos produtivos (fases de produção, cadeia produtiva etc.), gerenciais e de concepção dos produtos e processos, sem que exista qualquer modificação no uso concreto que deles se faz.

3) Revitalização ou repotenciamento das máquinas e equipamentos: significa não só o aumento da vida útil das máquinas e equipamentos, mas também ajustes, recondicionamento e revitalização do maquinário. Supõe ainda a fertilização das tecnologias "antigas" com componentes novos. 
4) Ajuste do processo de trabalho: implica a adaptação da organização do processo de trabalho à forma de propriedade coletiva dos meios de produção (preexistentes ou convencionais), 0 questionamento da divisão técnica do trabalho e a adoção progressiva do controle operário (autogestão).

5) Alternativas tecnológicas: implica a percepção de que as modalidades anteriores, inclusive a do ajuste do processo de trabalho, não são suficientes para dar conta das demandas por AST dos empreendimentos autogestionários, sendo necessário o emprego de tecnologias alternativas à convencional. A atividade decorrente desta modalidade é a busca e a seleção de tecnologias existentes.

6) Incorporação de conhecimento científico-tecnológico existente: resulta do esgotamento do processo sistemático de busca de tecnologias alternativas e na percepção de que é necessária a incorporação à produção de conhecimento científico-tecnológico existente (intangível, não embutido nos meios de produção), ou o desenvolvimento, a partir dele, de novos processos produtivos ou meios de produção, para satisfazer as demandas por AST. Atividades associadas a esta modalidade são processos de inovação de tipo incremental, isolados ou em conjunto com centros de pesquisa e desenvolvimento (P\&D) ou universidades.

7) Incorporação de conhecimento científico-tecnológico novo: resulta do esgotamento do processo de inovação incremental em função da inexistência de conhecimento suscetível de ser incorporado a processos ou meios de produção para atender às demandas por AST. Atividades associadas a esta modalidade são processos de inovação de tipo radical que tendem a demandar o concurso de centros de P\&D ou universidades e que implicam a exploração da fronteira do conhecimento.

Diante do exposto, o que está em discussão é a necessidade de contar com uma tecnologia capaz de alavancar um estilo alternativo de desenvolvimento e estas modalidades apoiarão no exame posterior do estudo de caso e seus impactos. No âmbito dos atores sociais envolvidos na construção desta tecnologia as instituições públicas envolvidas com a geração de conhecimento científico e tecnológico (universidades, centros de pesquisa etc.) constituem-se como sujeitos importantes e favorecedores de possibilidades tecnológicas adequadas às necessidades sociais dos EESs (DAGNINO et al. 2004). 


\subsection{Exemplos de tecnologias geradas no âmbito de uma relação sociotécnica}

Os exemplos ilustrados aqui são parte dos estudos realizados pelo pesquisador Hernán Thomas do Grupo de Estudios Sociales de la Tecnología y la Innovación da Universidade de Quilmes na Argentina. Em seus estudos, Thomas utiliza dois exemplos para identificar os limites do processo de construção da tecnologia social. Um exemplo trata de um projeto de coletores de névoa no Chile e outro de biodigestores para geração de gás metano na Índia. Em seus exemplos, é importante destacar, o exame das dificuldades encontradas em cada projeto a partir de categorias de análise: aspectos político-institucionais, aspectos sócio-institucionais e aspectos sócio-culturais.

O projeto de coletores de névoa foi uma experiência orientada a provisão de água potável, desenvolvida na cidade de Chungungo (norte do Chile), no final da década de 1980. O objetivo originário do projeto era a obtenção de água para plantio mediante a captura da umidade do ambiente. Este projeto recebeu financiamento de órgãos públicos e foi desenvolvido por pesquisadores da Universidade Católica do Chile.

O sistema é formado por coletores de água (estruturas retangulares com malhas duplas de nylon de quatro metros de altura e 12 metros de largura somados a um sistema de armazenamento e distribuição), administrado em conjunto pelos pesquisadores e um comitê de águas local. Os pesquisadores consideraram que o sistema era fácil de construir e operar requeria baixa experiência e era de fácil compreensão por usuários com baixa formação tecnológica. 

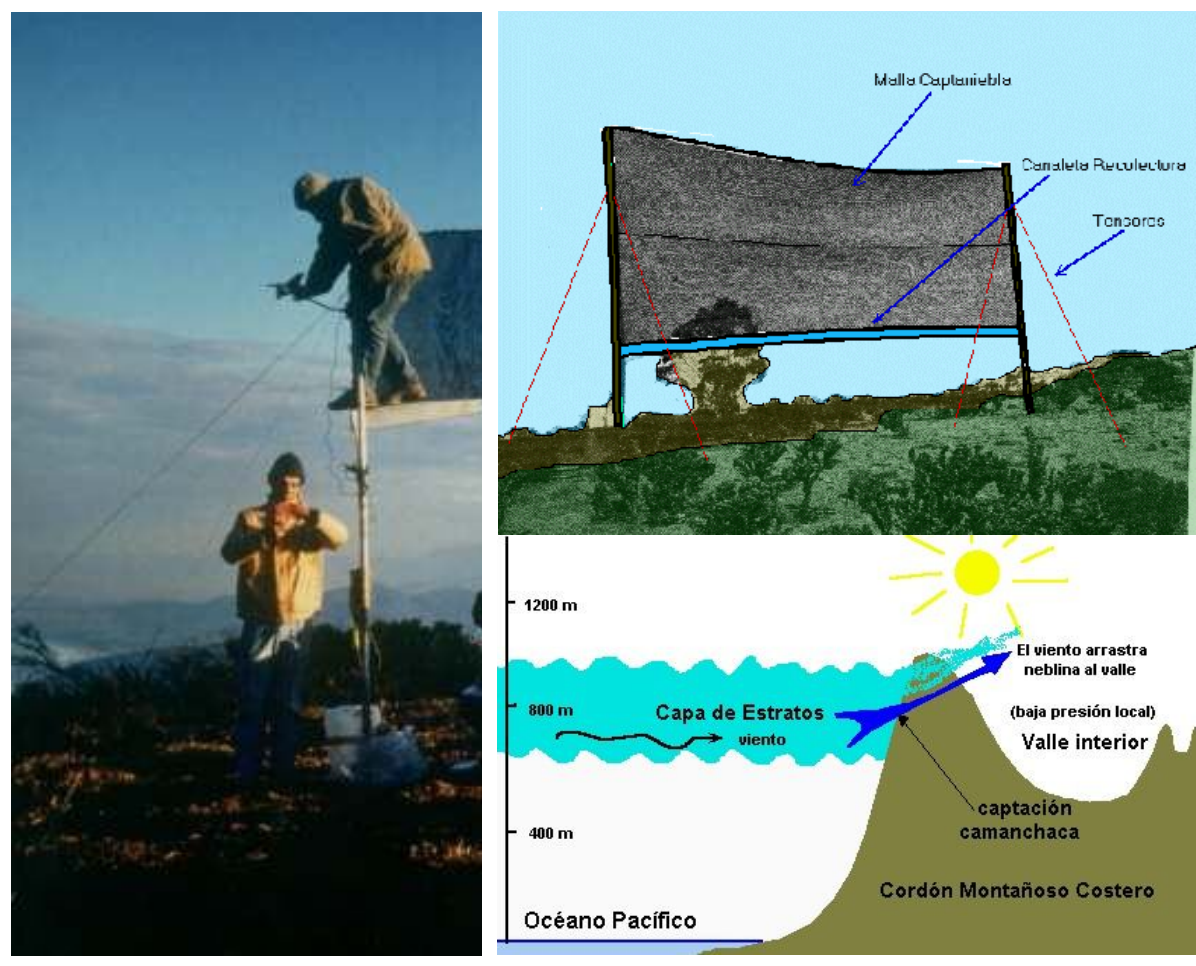

Figura 2 Coletores de névoa desenvolvidos na cidade de Chungungo (norte do Chile).

Fonte: Thomas (2009)

Nas experiências-piloto, esses cata-neblinas conseguiam recolher 237 litros de água por dia, em média cinco litros por metro quadrado. Ao observar os resultados obtidos e o volume de água que foi possível recolher com esse sistema, os distintos atores envolvidos consideraram que podiam abastecer de água potável uma população isolada.

Com forte apoio institucional e financeiro, desde o fim dos anos 1980 até 1996, foram instalados 92 coletores. No entanto, até 2001 , só funcionavam 12, como complemento ao fornecimento de água potável obtido por meio de caminhões cisterna. Descontinuado o apoio inicial, diversas dificuldades se conjugaram ao abandono do projeto (ANTON, 1998; DE LA LASTRA, 2002 apud THOMAS, H, 2009), entre elas: Aspectos político-institucionais: Privatização da empresa (comunitária) de serviços sanitários; Aspectos socioinstitucionais: Inexistência de estrutura local permanente para a tomada de decisões e administração; Falta de manutenção por parte de técnicos capacitados; Aspectos socioculturais: Recente desconfiança da população diante de uma tecnologia que começaram a perceber como instável e pouco confiável. 
Desde meados dos anos 1960, foi desenvolvido na Índia extenso programa de produção de gás mediante reatores de biomassa. Sob a ideia de proporcionar aos usuários finais (grupos familiares e comunitários) um meio eficaz para ferver alimentos e evitar assim doenças associadas a micróbios e infecções, tanto o estado quanto diversas agências internacionais promoveram e financiaram a construção de biodigestores.

Avaliações recentes têm registrado forte subutilização da capacidade instalada. Um relatório do ano 2002 indica que se encontravam em pleno funcionamento 55\% dos de uso dos grupos familiares e 7,3\% dos de uso comunitário (GOBIERNO DE LA INDIA, 2002 apud THOMAS, 2009, p.31). Diversas são as explicações, mas duas das principais chamam a atenção sobre os supostos cognitivos sob os quais se criou o programa: Aspectos socioculturais: Tabus religiosos associados ao contato com o esterco animal; Divisão social do trabalho associada ao sistema de castas; Aspectos socioeconômicos: Atribuição de um preço à matéria-prima do processo (considerada inicialmente "gratuita" e de livre disponibilidade); Conflito de direitos de propriedade do esterco.

Segundo Thomas (2009, p. 32) isso permite explicar não só a subutilização em termos absolutos dos biodigestores, mas também permite compreender o diferencial no regime de uso entre biodigestores familiares e comunitários (sujeitos a um maior conflito social).

Thomas (2009, p. 32) ressalta a importância dos casos não exitosos para construção das TSs, mas também ressalta a necessidade de caracterização precisa dos casos.

Como se deriva dos dois casos analisados, o não funcionamento dessas tecnologias reflete sérios problemas de concepção de componentes e sistemas.

Essas disfunções não se explicam, simplesmente, por motivos sociais da "não adoção" de um componente "tecnicamente bem desenvolvido". O projeto completo dos cata-neblinas supunha certa organização social e capacidades cognitivas por parte dos usuários e da administração local. 0 projeto completo dos biodigestores presumia que o esterco gratuito nunca se converteria em um bem de troca e que nunca haveria conflitos em relação à apropriação de benefícios diretos e derivados.

Na base do que normalmente se diagnosticaria como "problemas de implementação" dessas duas tecnologias, é possível registrar problemas de conceito de projeto, derivados por sua vez de problemas de conceituação das TSs.

Por isso, é necessário realizar uma revisão crítica das conceituações normalmente utilizadas pelos criadores, policy makers, científicos e tecnólogos, agentes públicos, ativistas sociais, membros de ONGs, entre outros, na hora de conceber, implementar, administrar e avaliar TSs. (THOMAS, 2009, p. 32)

Outro exemplo de tecnologia adequada a um contexto social foi a gerada no processo de incubação da Cooperativa de Produção dos Jovens da Região do Sisal (COOPERJOVENS) pela ITCP da Universidade do Estado da Bahia (ITCP/UNEB). Em seu estatuto, a COOPERJOVENS definiu como uma de suas atividades econômicas a produção industrial de artefatos de cimento reforçados 
com sisal. Esta demanda foi reforçada pela instauração de uma linha de pesquisa na incubadora que remontava a experiência da década de 1980 do Centro de Pesquisas e Desenvolvimento (CEPED), sobre compósitos de fibras em matrizes à base de cimento, agora integrada às ações para geração de trabalho e renda (GUIMARÃES; VIANNA; NOGUEIRA, 2007).

Segundo Guimarães, Vianna e Nogueira (2007) a COOPERJOVENS é caracterizada como uma cooperativa popular que reúne jovens de 13 municípios da região sisaleira, filhos de pequenos agricultores em busca de alternativas de trabalho e renda para a permanência e atuação nos locais de origem. $\mathrm{O}$ projeto em que se desenvolveu a produção dos artefatos de cimento e sisal (PROSISAL) foi desenvolvido de 2002 a 2006 e compreendeu as seguintes etapas: a) mobilização e integração dos agentes locais; b) desenvolvimento do compósito sisal-cimento considerando os aspectos de durabilidade, aproveitamento de resíduos, facilidade do processo produtivo e resistência aos esforços mecânicos; c) desenvolvimento de componentes de edificações inovadores, aliando leveza, beleza e desempenho estrutural; d) desenvolvimento do processo produtivo dos componentes e e) vivência e apropriação da tecnologia integrada ao processo de incubação (UNE/PROEXT/ITCP, 2006 apud GUIMARÃES; VIANNA; NOGUEIRA, 2007). Este projeto segundo os autores, contou com apoio financeiro da Financiadora de Estudos e Projetos / FINEP por meio dos programas HABITARE Programa de Tecnologia da Habitação (para financiamento da pesquisa) e PRONINC - Programa Nacional de Incubadoras Tecnológicas de Cooperativas Populares (apoio ao processo de incubação da cooperativa) e do Banco do Nordeste/ETENE-FUNDECl${ }^{14}$. Este último participou como interveniente co-financiador do projeto com $20 \%$ do valor requerido. Os autores enfatizam o ineditismo dessa ação uma vez que o Banco do Nordeste aceitou a participação como co-financiadora após a COOPERJOVENS ter submetido o PROSISAL à chamada do edital da FINEP/HABITARE. O caráter inédito figura no fato da cooperativa ter conseguido os recursos da FINEP se apresentando como interveninete sem, para isto, apresentar quaisquer contrapartida financeira inicial, mas apenas o compromisso de conseguir uma empresa privada como interveniente co-financiadora após a aprovação do projeto na FINEP.

\footnotetext{
14 Fundo de Desenvolvimento Científico e Tecnológico do Banco do Nordeste
} 


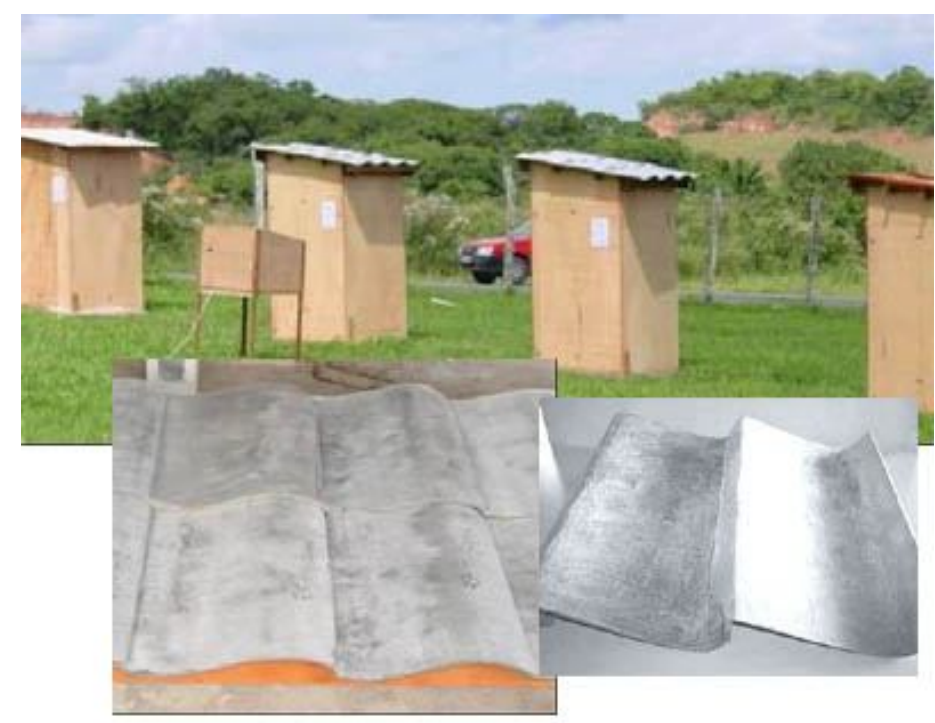

Figura 3 Telha capa-canal de sisal.

Fonte: Guimarães, Vianna e Nogueira (2007)

O PROSISAL articula a vocação das pequenas propriedades bahianas entorno do sisal, o baixo aproveitamento da fibra nos processos tradicionais e a capacidade instalada dos laboratórios de pesquisa da região. O projeto, após estudos de viabilidade (consultas as lojas de materiais de construção e aos produtores de sisal) identificou a potencialidade da produção de telhas do tipo capa-canal na qual utilizou-se o resíduo do processo de beneficiamento da fibra do sisal (a bucha). O desnevolvimento do produto, segundo os autores Guimarães, Vianna e Nogueira (2007), foi feito em laboratório do CEPED com a participação dos jovens em oficinas de transferência de tecnologia.

Desde a fundamentação desta proposta de trabalho (pesquisa do PROSISAL), a relação com o público beneficiário dos resultados da pesquisa foi de parceria. Parceria exprime relação de troca entre o meio físico-social e os sujeitos de saberes. Já a relação entre sujeito e objeto do conhecimento passa a ser inadequada, pois expressa um processo hierárquico, fator de distanciamento entre a cultura da academia e a cultura dos sujeitos pesquisados e/ou beneficiados pelos resultados da pesquisa (GUIMARÃES, 2006).

Desta relação de parceria Guimarães et al. (2006) resgatam a proposta pedagógica do aprender fazendo revelando as premissas de (FREINET, 1969, 1974 apud ELIAS 1997, p. 21-31; FREIRE, 1993, 1996) nas quais deve-se buscar sempre valorizar o contexto social de cada indivíduo no processo de construção coletiva. 
Os autores justificam a proposta de transferência de tecnologia por meio de oficinas embasados no o princípio vygotskyano de zona de desenvolvimento proxima/15 uma vez que segundo os autores

\begin{abstract}
O processo vem se dando através de oficinas de trabalho com base na tríade prática, teoria e prática. Cada um desses elementos possui o mesmo grau de importância. A premissa norteadora dessa prática é a da leitura do mundo precedendo a dos livros, de acordo com Freire (1993), ou seja, o sujeito constrói sua própria aprendizagem a partir da troca com um companheiro de mesmo nível na aprendizagem ou numa etapa mais à frente.

Daí a proposta da equipe de trabalhar todo o processo de transferência tecnológica a partir de oficinas, à medida que os resultados da pesquisa forem surgindo. Ao todo ocorreram três oficinas, entretanto a última se deu durante uma semana, compreendendo seis minioficinas. Em todas elas há momentos de reflexão da teoria e da prática para alcance das metas previstas, ou seja, os cooperantes fabricando telhas de forma autogestionária e cada um deles dominando o processo num todo (GUIMARÃES et al., 2006, p.61).
\end{abstract}

Guimarães, Vianna e Nogueira (2007) ressaltam os seguintes aspectos relacionados a tecnologia gerada no âmbito do PROSISAL: a) O acesso de um empreendimento popular à inovação tecnológica traz a possibilidade de oferta de um produto diferenciado ao mercado, fortalecendo a autonomia do grupo; b) A possibilidade de redução da migração dos jovens do interior do Estado para as periferias das cidades, com a geração de trabalho e renda; c) A busca de novos usos para o sisal, de grande importância econômica,com forte influência na cultura da região; d) A possibilidade de substituição do amianto na produção de componentes de edificações à base de cimento e fibras; e) A utilização de um resíduo - a bucha do sisal - na produção dos componentes.

Como síntese do apresentado neste capítulo, inferimos que é necessário constituirmos bases tecnológicas mais adequadas para a articulação dos princípios da economia solidária no âmbito da atuação das ITCPs e dos EESs. Os casos apresentados indicam a importância da participação da comunidade envolvida em todas as etapas do processo produtivo, do desenho do processo e estratégias para tomada de decisões até a inserção do produto no sistema de circulação de mercadorias. Foi possível notar que para efetivar esta participação é necessário o envolvimento das instituições de pesquisa e financiadoras na articulação de recursos e conhecimentos, no entanto, a participação dos membros do empreendimento e da comunidade nas etapas de desenvolvimento do produto são determinantes para a sustentação do processo.

15 Zona de desenvolvimento proxima é a distância entre o nível de desenvolvimento real, que se costuma determinar através da solução independente de problemas, e o nível de desenvolvimento potencial, determinado através da solução de problemas sob a orientação de um adulto ou em colaboração com companheiros mais capazes. (VYGOTSKY, 1994, p. 172 apud GUIMARÃES et al., 2006). 


\section{PeRguntas de PESQUisa, hipóteses, estratégias de PESQUISA E MÉTODO DE COLETA}

A revisão da literatura sobre economia solidária, autogestão e sobre a tecnologia social propiciou a identificação de variáveis importantes para entendermos 0 universo que envolveu a pesquisa se configurando assim, como parte essencial na formulação da pergunta e das hipóteses de pesquisa. Configura-se, também, como elemento balizador do método adotado por esta pesquisa a participação ativa do pesquisador nos processos de incubação de empreendimentos econômicos solidários, em especial, da Marcenaria Coletiva de Mulheres. Esta participação (meados de 2006 ao final de 2010) como assessor, educador e pesquisador permitiu a identificação de obstáculos, limites e desafios no processo de incubação assim como, possibilitou sistematizar as ações para superação destes obstáculos e limites em conjunto com equipes de pesquisa e assessoria e, principalmente, em conjunto com as marceneiras. Assim, a revisão da bibliografia sobre os fenômenos envolvidos e a participação na ação de um empreendimento econômico solidário são elementos fundamentais na escolha da estratégia de pesquisa e, consequentemente, na escolha das ferramentas e formas de análise dos dados.

Neste capítulo serão caracterizados os métodos de pesquisa utilizados os quais podemos citar: i) a pesquisa-ação como estratégia geral da pesquisa e método adequado ao cumprimento do papel das universidades; ii) o estudo de caso tendo a Marcenaria Coletiva de Mulheres do assentamento rural Pirituba II, em Itapeva-SP como objeto empírico e iii) e estudo pós-fato na medida que dados coletados anteriormente a participação do pesquisador na assessoria ao empreendimento foram estudados.

Cabe ressaltar, também o caráter exploratório da pesquisa já que a pesquisa exploratória busca proporcionar uma visão geral acerca de determinado fato (GIL, 1999). Esta característica da pesquisa facilita a verificação dos aspectos facilitadores e dificultadores relacionados à prática autogestionária e a adequação sociotécnica na produção de janelas na marcenaria.

Espera-se, assim, que o conhecimento gerado neste processo de câmbio entre literatura e ação possa orientar a atuação dos assessores às práticas econômicas solidárias, encontrados nas incubadoras tecnológicas de cooperativas populares e nos laboratórios de pesquisa, de maneira adequada às necessidades e características destes empreendimentos. 


\subsection{Perguntas, hipóteses e objetivos de pesquisa}

Os empreendimentos econômicos solidários (EES) apresentam-se como elementos fundamentais na construção do movimento da economia solidária. É reivindicado nesse movimento que é papel do Estado garantir a atuação destes EESs de maneira sustentável. Podemos citar como atores da mediação entre este papel do Estado e os EESs as incubadoras tecnológicas de cooperativas populares (ITCPS) que assumem, dentre outros responsabilidades, a indissociabilidade entre pesquisa, ensino e extensão. Construir ferramentas adequadas para a atuação dos membros das ITCPs nos processos de incubação de EESs é ação contínua, pois a complexidade das relações construídas no âmbito dos empreendimentos em meio a um sistema caracterizado por relações de mercado e, predominantemente, monetárias, impulsiona a superação permanente de desafios enfrentados nestes processos. São enfrentamentos comuns aos assessores de EESs a dinâmica relacionada à cadeia produtiva, às relações inter e intragrupais, os recursos escassos e os conhecimentos e tecnologias necessários para viabilizar o empreendimento. Como maneira de contribuir com a atuação destes assessores buscamos responder a seguinte pergunta de pesquisa: quais fatores mais contribuíram para o sucesso e quais mais dificultaram o avanco da marcenaria em produzir janelas de madeira autogestionariamente? Da pergunta principal as hipóteses verificadas na Tabela 6.

Tabela 6 Hipótese principal da pesquisa

Fatores que mais contribuíram para o sucesso da marcenaria em produzir janelas de madeira autogestionariamente:

- adotar a autogestão como processo educativo contínuo e permanente que perpassa todas as etapas de formação do empreendimento;

- identificar os gargalos relacionados a cadeia produtiva em que o empreendimento se encontra e construir alternativas de superação destes;

- realizar parcerias com pessoas e instituições mais próximas do território de atuação do empreendimento e

- inserir no empreendimento jovens do próprio assentamento.

Fatores que mais dificultaram para 0 avanço da marcenaria em produzir janelas de madeira autogestionariamente:

- a dificuldade de processar conflitos pessoais e interpessoais;

- a alta carga de trabalho realizado pelas marceneiras (manutenção da casa, cuidados com o cultivo de alimentos e cuidados da família) e

- a grande distância entre a sede dos assessores/pesquisadores e a sede da marcenaria (400 km). 
Destaca-se como objetivo geral da pesquisa identificar e examinar os fatores que mais contribuiram e mais dificultaram o desenvolvimento e produção autogestionária de janelas de madeira. Como objetivos específicos temos:

a) Examinar como 0 método adotado na incubação da marcenaria favoreceu 0 desenvolvimento e a produção autogestionária de janelas.

b) Identificar as estratégias adotadas e condições ofertadas pelos assessores a marcenaria que viabilizaram a produção das esquadrias em um processo autogestionário;

c) Identificar quais os momentos do processo de incubação da marcenaria e como a incubação se relaciona ao processo produtivo;

d) Examinar o grau de participação dos membros da marcenaria nas etapas de desenvolvimento e produção de janelas.

Na figura 4 estão expostos as perguntas principal e intermediárias e suas respectivas hipóteses (quadro contorno laranja) e objetivos (quadro contorno vermelho). 
Hipótese Principal

0 fato da marcenaria estar inserida em um processo de incub ação contínuo e per manente voltado ao aumento da compreensöo dos membros sobre a autogestõo, sobre $a$ oportunidades e dificuldades relacionadas à atividade econômica e ao processo produtivo contribuiu pa a o aumento grad ativo da particip ação ativa dos membros da marcen aria nos processos decisórios sobre aspectos estr at égicos e operacionais da produçẫo de janelas de madeira.

Osconflitos pessoais e interpessoais não processados, a alta carga de responsabilidade das mar ceneir a (manutenção da casa, cuidados do cultivo de alimentos e cuidados da familial e adistância entre a sede dos assessores/pesquisador es e a sede da marcenaria dificultaram o avanço da marcenaria em produzir e, principalmente, desenvolver janelas de madeira autogestionariamente.

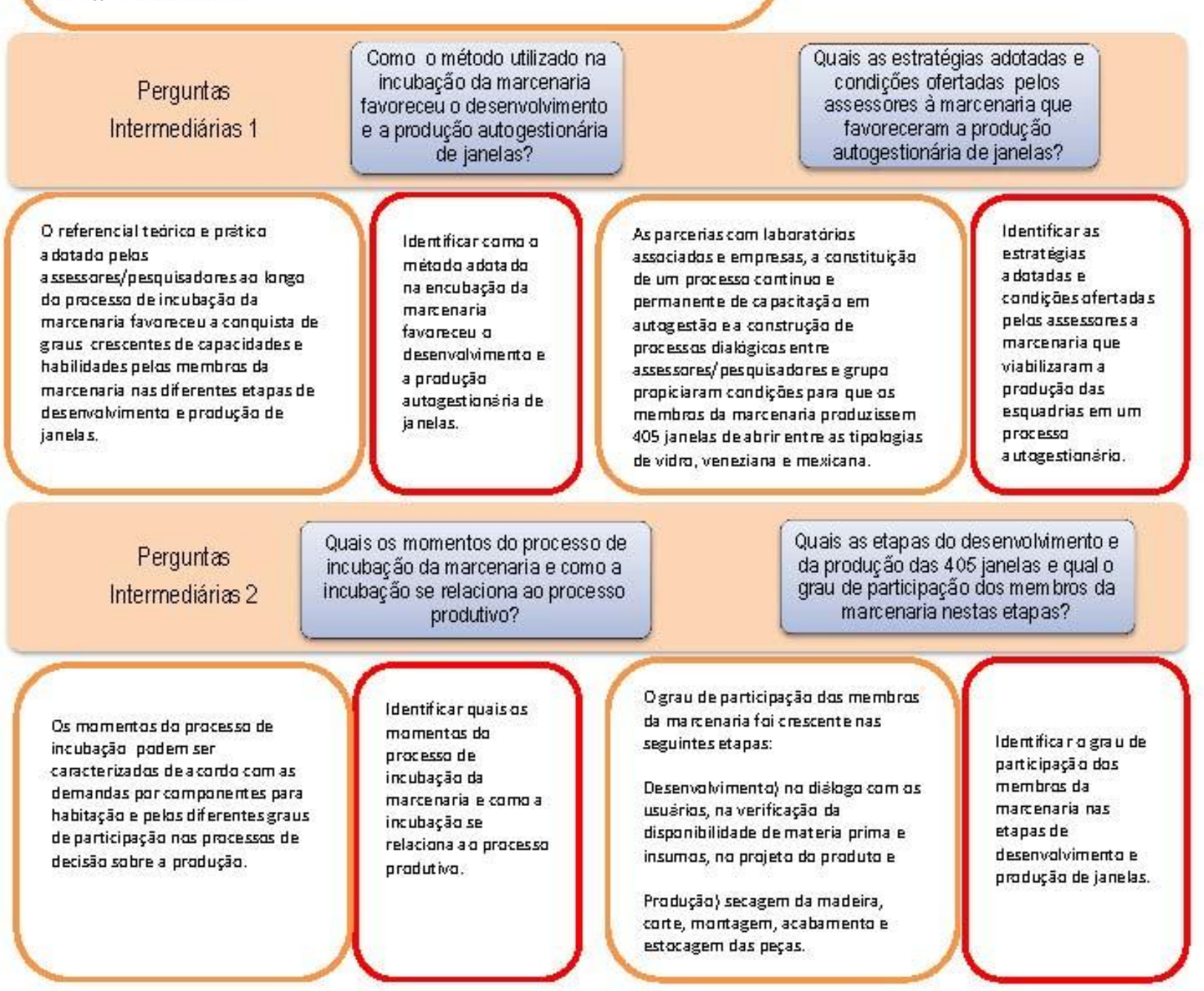

Figura 4 - Perguntas, objetivos e hipóteses de pesquisa.
Identifica e examina osfares que mais contribuir am e mais dificultaram o deservolvimento eproduçăo autogestionária de janelas de madeira 


\subsection{Estratégias de pesquisa}

Buscamos a partir das perguntas, hipóteses e objetivos de pesquisa abarcar as discussões a cerca da adequação sociotécnica, suas possíveis relações com processos de incubação de EES e a autogestão. Aplicado ao objeto empírico de estudo, esta revisão busca relacionar a produção autogestionária de componentes de madeira para habitação em uma marcenaria coletiva em processo de incubação que tem como agentes desta incubação: mulheres e jovens do próprio assentamento, a Incubadora Regional de Cooperativas Populares da Universidade Federal de São Carlos (INCOOP), grupos de pesquisa e laboratórios de Instituições de Ensino Superior como o Grupo de Pesquisa em Habitação e Sustentabilidade do Instituto de Arquitetura e Urbanismo da Universidade de São Paulo (HABIS), o Laboratório de Ciências Florestais da Escola Superior de Agricultura "Luiz de Queiroz" da Universidade de São Paulo (ESALQ), gestores de políticas públicas da Fundação Instituto de Terras do Estado de São Paulo (ITESP) e empresas da região como a Marcenaria Alberti.

A proposta é elencar, caracterizar e examinar os produtos e processos desenvolvidos no âmbito do processo de incubação tendo como foco as estratégias gerais adotadas pela assessoria para os serviços qualificados da marcenaria e para a incubação, assim como, examinar os resultados alcançados na produção dos seguintes componentes para habitação: Janelas Pirituba (144 janelas de 1,20 x 1,20 m da tipologia de abrir de vidro) e Janelas Sepé (361 janelas, sendo: 201 janelas do tipo de abrir de vidro; 55 janelas do tipo de abrir mexicana e 105 janelas do tipo de abrir veneziana).

Em suma, para atendimento dos objetivos propostos foram adotadas como estratégias gerais da pesquisa: 1) pesquisa-ação, 2) análise pós-fato e 3) estudo de caso. O estudo de caso aborda um empreendimento coletivo autogestionário de produção de componentes para habitação em madeira proveniente de plantios florestais quanto ao seu processo de projeto e produção das janelas, considerando principalmente a adoção da autogestão como princípio e adequação sociotécnica como meio para alcance dos resultados esperados.

\subsubsection{Pesquisa-ação}

A primeira distinção necessária para tratarmos do tema da pesquisa ação é colocar que ela não é uma metodologia. Segundo Michel Thiollent a pesquisa ação é um tipo de pesquisa social que apresenta coerência com os trabalhos de incubação abordados pela concepção da epistemologia da comunicação, como ato dialógico e educativo, podendo se constituir, como veremos abaixo, como método de referência do trabalho de pesquisadores neste campo. Sobre o conteúdo da Pesquisa-ação Thiollent afirma: 
Trata-se de um método, ou de uma estratégia de pesquisa agregando vários métodos ou técnicas de pesquisa social, com os quais se estabelece uma estrutura coletiva, participativa e ativa ao nível de captação da informação.....Como estratégia de pesquisa, a PA pode ser vista como modo de conceber e organizar uma pesquisa social de finalidade pratica e que esteja de acordo com as exigências próprias da ação e da participação dos atores da situação observada. Neste processo, a metodologia desempenha um papel de 'bússola' na atividade dos pesquisadores, esclarecendo cada uma de suas decisões por meio de alguns princípios de cientificidade" (THIOLLENT, 2005, p.28)

Associada a várias formas de ação coletiva, a pesquisa ação se orienta por objetivos de transformação, pela resolução de problemas de ordem imediata ou pelo esclarecimento dos problemas da situação investigada. Para sua realização há não só a mera participação dos pesquisadores, mas estes devem pensar a realidade e transformá-la em conjunto com o grupo interessado, numa interação ampla e explicita (mesma postura do comunicador preocupado com a comunicação popular). As ações do grupo nunca devem ser substituídas pelas dos pesquisadores, os quais buscam orientar suas ações aumentar o conhecimento e o "nível de consciência" e autonomia de todos os envolvidos. (THIOLLENT, 2005, p.18-19)

O grau de envolvimento dos pesquisadores na pesquisa-ação é que a distingue da pesquisa participante. Esta nem sempre pressupõe ação do pesquisador, se caracterizando pela "observação participante na qual os pesquisadores estabelecem relações comunicativas com pessoas ou grupo da situação investigada com o intuito de serem melhor aceitos.".(THIOLLENT, 2005, p . 17)

É uma pesquisa de ordem empírica, que se amplia para reflexões teóricas do micro para o macro social, a partir das relações dialógicas entre pesquisadores e membros da situação investigada. $\mathrm{O}$ que quer dizer que os saberes são relativizados e postos em troca: pesquisadores e grupo aportam teorias e experiências de vida para resolver um problema da realidade social, sendo que a questão teórica é de responsabilidade do pesquisador, mas pode também vir do grupo. 0 pesquisador disponibiliza também sua experiência de vida, assim como o grupo. Para tanto, a atitude do pesquisador é uma "atitude de escuta e de elucidação dos vários aspectos da situação, sem imposição unilateral de suas concepções próprias". (THIOLLENT, 2005, p.20)

A transformação pretendida pela pesquisa-ação requer que ela aconteça mediante a ação planejada (diagnóstico, pesquisas, ações divididas e realizadas, avaliação, acúmulos, ações...) no âmbito social. Esse planejamento deve ser coletivo e de fácil visualização, embora visto como algo dinâmico. Portanto, é necessário o uso e criação de técnicas de planejamento que possam sobretudo ser apropriadas pelos grupos.

De modo sintético, Thiollent conclui: 
[...] a pesquisa-ação é um tipo de pesquisa social com base empírica que é concebida e realizada em estreita associação com uma ação ou com a resolução de um problema coletivo e no qual os pesquisadores e os participantes representativos da situação ou do problema estão envolvidos de modo cooperativo e participativo.(THIOLLENT, 2005, p 16)

Para que seja um processo participativo de fato os membros da situação investigada devem contribuir desde o momento de definição dos objetivos, que podem ser de três tipos não excludentes: objetivos instrumentais, lembrando que a técnica não se separa do contexto sociocultural, objetivos de tomada de consciência e de produção de conhecimento. Ao definir-se o objetivo, o papel de cada um também deve ser explicitado, igualmente as suas intenções, limitações e possibilidades.

É importante que os objetivos sejam alcançáveis, sem criar ilusões, e que estejam vinculados explicitamente à ação transformadora, mesmo que numa dimensão local. O vínculo do local com o global é que trará para o grupo a noção mais abrangente. Mas parte-se do possível, a pesquisa ação se dá em termos realistas (THIOLLENT, 2005, p. 42)

Os conhecimentos para se alcançar o objetivo precisam ser pontuados. Quanto maior conhecimento melhor a prática, mas, muitas vezes, a dinâmica cotidiana encurta 0 tempo para 0 conhecimento de modo que é preciso atentar para equalizar teoria e prática.

A pesquisa-ação fornece um conhecimento que não poderia ser apreendido em outra situação investigativa, pois por meio dela é possível apreender a dinamicidade do real. A esse respeito afirma Thiollent:

[...] os problemas, decisões, ações, negociações, conflitos e tomadas de consciência que ocorrem entre os agentes durante 0 processo de transformação da situação....De modo geral, a observação do que ocorre no processo de transformação abrange problemas de expectativas, reivindicações, decisões, ações e é realizada através de reuniões e seminários nos quais participam pessoas de diversos grupos implicados na transformação. As reuniões e seminários podem ser alimentados por informações obtidas em grupos de pesquisa especializados, por assuntos e também por informações provenientes de outras fontes, inclusive - quando utilizáveis - aquelas que foram obtidas por meios convencionais: entrevistas, documentação etc..." (THIOLLENT, 2005, p.22)

Sendo assim, a pesquisa-ação se coloca como um fazer científico não positivista, pois as influências socioculturais trazidas por cada sujeito alteram os resultados, bem como 0 ambiente macro social, tendo que ser concebida de modo aberto. Para isso a "pesquisa ação deve ficar no âmbito das ciências sociais, podendo inclusive ser enriquecida com as contribuições de outras linhas compatíveis (em particular, linhas metodológicas concentradas na análise da linguagem em situação social)"(THIOLLENT, 2005,p. 24). 


\subsubsection{Estudo de caso: Marcenaria Coletiva de Mulheres}

O presente estudo exporá como estudo de caso um processo de pesquisa-ação que envolveu a participação de assentados, assessores e pesquisadores na implantação de uma marcenaria coletiva em meio ao processo de incubação no Assentamento Rural Pirituba II, Itapeva, sudoeste do estado de São Paulo, entre agosto de 2006 e dezembro de 2010. Nessa trajetória, a simultaneidade entre pesquisa e ação, característica inerente aos processos de incubação de EES, propiciou um processo de organização e sistematização de dados e informações que serviram como base para o exame tanto das questões, desafios e potencialidades advindas da discussão sobre as relações entre tecnologia e economia solidária, quanto das relações entre o grau de participação do trabalhador em todas as etapas de produção e o seu empoderamento.

Assim como todo estudo de caso, não esgota e nem traz a tona toda a complexidade do tema, mas, considera as especificidades e, em certa medida, os limites no processo de incubação e desenvolvimento de produtos neste tipo de empreendimento, particularmente, no âmbito da cadeia da madeira de plantios florestais.

A coleta de dados para este estudo refere-se ao trabalho desenvolvido entre meados de 2006 e 2010 envolvendo as equipes de pesquisa dos vários centros de produção de conhecimento, as mulheres e jovens membros da marcenaria e ainda no período inicial um instrutor em serviços qualificados para marcenaria. A coleta de dados ocorreu ao longo processo de incubação em encontros periódicos à sede do empreendimento e acompanhamento da produção de componentes para habitação, em especial janelas, envolvendo contatos com especialistas sobre cadeia da madeira e sobre processos de incubação de empreendimentos econômicos solidários. Foi realizado análise documental junto a projetos, fotos, planilhas e relatórios desenvolvidos pelos pesquisadores, além de artigos científicos afins ao tema do trabalho. Os instrumentos utilizados foram as planilhas e perguntas transversais (ferramenta de coleta testada e utilizada no âmbito do trabalho do HABIS), relatos de reuniões e diários de campo.

Em síntese, o estudo de caso aborda um EES de produção de componentes para habitação em madeira proveniente de plantios florestais quanto ao processo de desenvolvimento de produto, considerando principalmente a integração entre projeto, produção, a adoção da autogestão como princípio e as estratégias de parcerias com laboratórios e centros de produção de conhecimento científico e tecnológico. Assim, configuram-se como processos a serem examinados no âmbito da incubação da Marcenaria Coletiva de Mulheres: 
1) Processo de projeto e processo de produção de 144 janelas para o Assentamento rural Pirituba II, Itapeva/SP (referente ao momento três do processo de incubação da Marcenaria de Mulheres que se iniciou em 2004 e finalizou em 2006);

2) Processo de projeto e processo de produção de 361 janelas para o Assentamento rural Sepé Tiarajú, Serrana/SP (referente ao momento cinco do processo de incubação da Marcenaria de Mulheres que se iniciou em 2007 e finalizou em 2008).
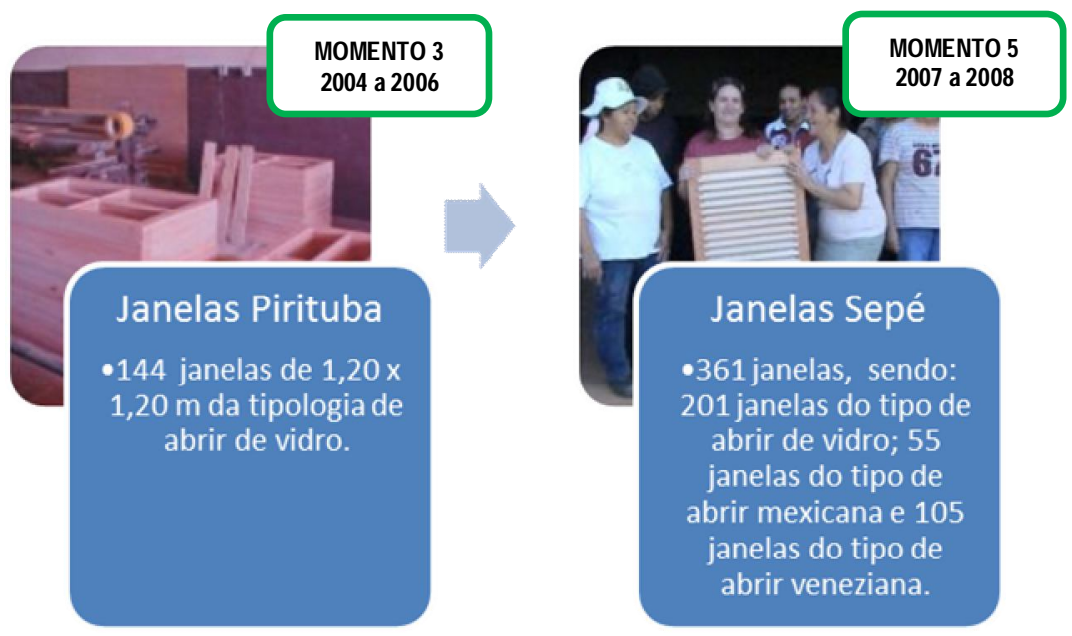

Figura 5 - Identificação dos momentos da marcenaria a serem caracterizados.

\subsubsection{Variáveis examinadas}

Serão caracterizados os processos de projeto e produção de janelas ao longo da incubação da Marcenaria Coletiva de Mulheres nos quais serão identificados em cada um desses momentos variáveis relevantes relacionados: i) ao grau de autogestão do empreendimento alcançado ao longo do tempo; ii) ao grau de empoderamento individual e coletivo e iii) processos de adequação sociotécnica realizados. Estas variáveis compuseram linhas do tempo que possibilitaram o exame dos fatores que favoreceram e que dificultaram a produção autogestionária de janelas, em especial, no que concerne a participação dos assessores nos momentos caracterizados. Abaixo segue quadro com as variáveis a serem examinadas. 
Tabela 7 - Classes de variáveis, subclasses de variáveis e variáveis examinadas.

\begin{tabular}{|c|c|c|}
\hline Classes de variáveis & $\begin{array}{l}\text { Subclasses } \\
\text { variáveis }\end{array}$ & Variáveis \\
\hline \multirow[t]{4}{*}{$\begin{array}{l}\text { Autogestão como processo } \\
\text { produtivo e educativo }\end{array}$} & $\begin{array}{l}\text { Evolução da posse ou } \\
\text { cessão coletiva dos } \\
\text { meios de produção }\end{array}$ & $\begin{array}{l}\text { Em relação a edificação; } \\
\text { Em relação a equipamentos; } \\
\text { Em relação a ferramentas; } \\
\text { Em relação a materiais (exemplo: madeira, insumos, etc.). }\end{array}$ \\
\hline & Fundo coletivo & $\begin{array}{l}\text { Utilização para Investimento; } \\
\text { Utilização para garantir direitos trabalhistas e de cidadania; } \\
\text { Garantia de materia prima (madeira) }\end{array}$ \\
\hline & $\begin{array}{l}\text { Participação } \\
\text { democrática nos } \\
\text { processos decisórios }\end{array}$ & $\begin{array}{l}\text { Espaços de decisão; } \\
\text { Frequência de decisão em atividades cotidianas e estratégicas; } \\
\text { Assuntos/questões de decisão; } \\
\text { Grau de participação das associadas nos espaços decisórios. }\end{array}$ \\
\hline & $\begin{array}{l}\text { Solidariedade } \quad \text { e } \\
\text { Cooperação }\end{array}$ & $\begin{array}{l}\text { Distribuição igualitária dos resultados e benefícios; } \\
\text { Práticas de estímulo a criação de outros empreendimentos; } \\
\text { Práticas cotidianas de envolvimento com melhorias na } \\
\text { comunidade externa ao empreendimento; } \\
\text { Formas de funcionamento do empreendimento relacionadas a } \\
\text { estratégia de comercialização (compras de insumos e } \\
\text { utilização de serviços locais ou de EES, se vinculadas a um } \\
\text { único cliente, etc.). } \\
\text { Processamento de conflitos: } \\
\text { - Intragrupo; } \\
\text { - Intergrupos: (assentamento, instituições de apoio e fomento, } \\
\text { agentes públicos e assessores). }\end{array}$ \\
\hline \multirow[t]{5}{*}{ Empoderamento } & Bem estar material & Grau de acesso a bens de consumo e serviços públicos \\
\hline & Consciência de gênero & $\begin{array}{l}\text { Grau de liberdade e sentido de competência pessoal, } \\
\text { redefinição de valores maternos e renegociação das relações } \\
\text { domésticas }\end{array}$ \\
\hline & $\begin{array}{l}\text { Participação } \\
\text { decisões }\end{array}$ & $\begin{array}{l}\text { Grau de influência do grupo nas várias etapas de projeto e } \\
\text { produção; } \\
\text { Graus de influência nas tomadas de decisão de órgãos } \\
\text { públicos para aumento ao acesso de direitos do cidadão } \\
\text { (saúde, educação, trabalho, lazer, etc.) }\end{array}$ \\
\hline & $\begin{array}{l}\text { Controle sobre os } \\
\text { recursos e benefícios }\end{array}$ & Grau de autonomia financeira; \\
\hline & $\begin{array}{l}\text { Capacidades técnicas } \\
\text { adquiridas }\end{array}$ & $\begin{array}{l}\text { Número de capacidades técnicas adquiridas pelo conjunto das } \\
\text { marceneiras }\end{array}$ \\
\hline \multirow[t]{3}{*}{ Adequação sociotécnica } & Processo de projeto & $\begin{array}{l}\text { Desenhos de produtos; } \\
\text { Construção de relações problema-solução; } \\
\text { Interação entre beneficiários/usuários; } \\
\text { Interação com provedores de conhecimento e insumos; } \\
\text { Processos de aprendizagem; }\end{array}$ \\
\hline & Processo de produção & $\begin{array}{l}\text { Construção de relações problema-solução; } \\
\text { Métodos de cálculo de desempenho; } \\
\text { Capacidades tecnológicas acumuladas; } \\
\text { Processos de aprendizagem; }\end{array}$ \\
\hline & Processo de gestão & $\begin{array}{l}\text { Relação capacitação em gestão do empreendimento e } \\
\text { adoção/adequação pelo grupo das técnicas ensinadas; }\end{array}$ \\
\hline
\end{tabular}


A Tabela 8 explicita as fontes de evidências, instrumentos de coleta e outros tipos de informações coletadas.

Tabela 8 - Planejamento de coleta de dados segundo hipóteses intermediárias para os componentes de madeira para habitação produzidos na Marcenaria Coletiva de Mulheres.

\begin{tabular}{|c|c|c|c|c|}
\hline Hipótese Principal & Hipóteses intermediárias & Tipos de informações & $\begin{array}{c}\text { Fontes de } \\
\text { evidência } \\
\text { (base para coleta } \\
\text { de dados) }\end{array}$ & $\begin{array}{l}\text { Instrumentos e } \\
\text { procedimentos de } \\
\text { coleta }\end{array}$ \\
\hline 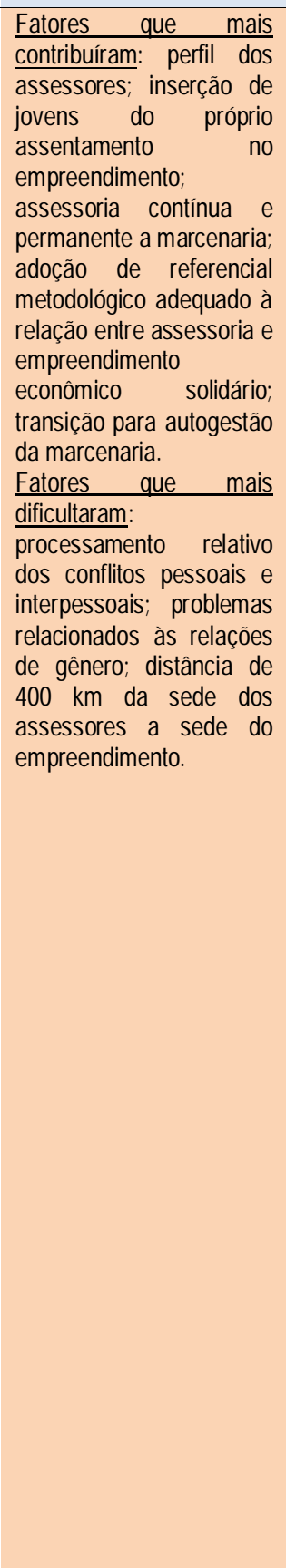 & 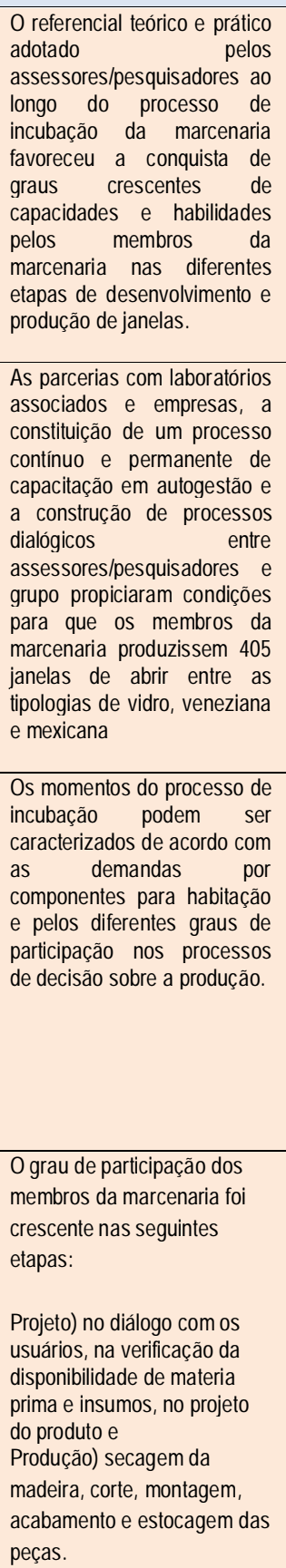 & $\begin{array}{l}\text { Processos e produtos } \\
\text { desenvolvidos relacionados ao } \\
\text { atendimento das demadas do } \\
\text { grupo e aos recursos existentes; } \\
\text { Formas de tomadas de decisão } \\
\text { pelo grupo sobre o processo } \\
\text { produtivo identificadas e } \\
\text { caracterizadas; } \\
\text { indicadores de participação } \\
\text { (tomada de decisão pelo grupo } \\
\text { nas diversas etapas do processo } \\
\text { de produção de compontentes, } \\
\text { efeitos e impactos da forma de } \\
\text { participação no grupo e nos } \\
\text { indivíduos, participação em } \\
\text { tomadas de decisão no cotidiano } \\
\text { da marcenaria, alteração da } \\
\text { relação de poder dentro da } \\
\text { família). } \\
\text { número de parcerias realizadas; } \\
\text { forma e momento de atuação da } \\
\text { parceria; } \\
\text { grau de incorporação dos } \\
\text { princípios da autogestão no } \\
\text { grupo; } \\
\text { forma de atuação da assessoria } \\
\text { nos processos de capacitação } \\
\text { para autogestão identificados; } \\
\text { demandas por capacitação } \\
\text { técnica identificadas e } \\
\text { caracterizadas e respectivas } \\
\text { formas de atuação e estratégias } \\
\text { adotadas pela equipe assessora } \\
\text { com os resultados alcançados } \\
\text { pela forma atuação; }\end{array}$ & $\begin{array}{l}\text { dados levantados } \\
\text { junto aos membros } \\
\text { da marcenaria; } \\
\text { dados levantados } \\
\text { ao longo do } \\
\text { processo de } \\
\text { incubação; } \\
\text { dados levantados } \\
\text { pelo Grupo HABIS } \\
\text { (diversos } \\
\text { pesquisadores); } \\
\text { dados levantados } \\
\text { pela INCOOP } \\
\text { (diversos } \\
\text { pesquisadores); } \\
\text { Parceiros do } \\
\text { processo de } \\
\text { incubação } \\
\text { (laboratórios, } \\
\text { empresas, gestores } \\
\text { de políticas } \\
\text { públicas, } \\
\text { cooperativas...); } \\
\text { Documentos } \\
\text { escritos e imagens: } \\
\text { Teses, dissertações, } \\
\text { bibliografias, } \\
\text { reportagens e } \\
\text { artigos } \\
\text { relacionados com o } \\
\text { tema; } \\
\text { Registro de } \\
\text { reuniões; } \\
\text { Relatórios de } \\
\text { pesquisa; } \\
\text { Vídeos e fotos do } \\
\text { acervo HABISe } \\
\text { INCOOP. }\end{array}$ & $\begin{array}{l}\text { Instrumentos e } \\
\text { procedimentos de } \\
\text { coleta: } \\
\text { anotações gerais } \\
\text { sobre o processo de } \\
\text { incubação da } \\
\text { marcenaria; } \\
\text { observação direta e } \\
\text { registros do } \\
\text { pesquisador e do } \\
\text { grupo de pesquisa na } \\
\text { ação; } \\
\text { anotações sobre o } \\
\text { processo de } \\
\text { desenvolvimento de } \\
\text { produtos; } \\
\text { anotações do caderno } \\
\text { do pesquisador e de } \\
\text { outros pesquiadores } \\
\text { do HABIS e INCOOP; } \\
\text { Fotografias do } \\
\text { processo das etapas } \\
\text { do processo de } \\
\text { incubação e de } \\
\text { produtos e processos } \\
\text { desenvolvidos; } \\
\text { dados da liteteratura } \\
\text { relacionada ao tema; } \\
\text { anotações do } \\
\text { processo de produção; } \\
\text { análise da literautura } \\
\text { geral e específica; } \\
\text { Análise da documen } \\
\text { tação existentes } \\
\text { (relatórios, relatos, } \\
\text { anotações, acervo } \\
\text { iconográfico, etc.) }\end{array}$ \\
\hline
\end{tabular}




\section{CARACTERIZAÇÃO DA PRODUÇÃO DE JANELAS NA MARCENARIA COLETIVA DE MULHERES}

O processo de mais de dez anos de incubação da marcenaria contou, em toda sua trajetória, com a participação de inúmeros parceiros com diversos papéis ao longo deste tempo. Neste processo foram fabricados pela marcenaria vários produtos e dentre eles janelas para dois assentamentos rurais. Espera-se que, o estudo das relações entre os agentes externos e a produção de janelas na Marcenaria Coletiva Autogestionária auxilie no exame do processo de transição para autogestão e da adequação sociotécnica. Desta forma, serão caracterizados neste capítulo: o contexto do surgimento da marcenaria, a caracterização do grupo de mulheres que integram a marcenaria, a identificação e caracterização dos momentos do processo de incubação e a descrição do processo de fabricação das janelas.

\subsection{Contexto histórico da Marcenaria Coletiva de Mulheres}

A marcenaria estudada localiza-se no sudoeste do estado de São Paulo, Itapeva, assentamento rural Pirituba II região com prevalência de riquezas naturais como áreas de plantios florestais em contraste aos baixos índices de desenvolvimento humano (Fig. 3).
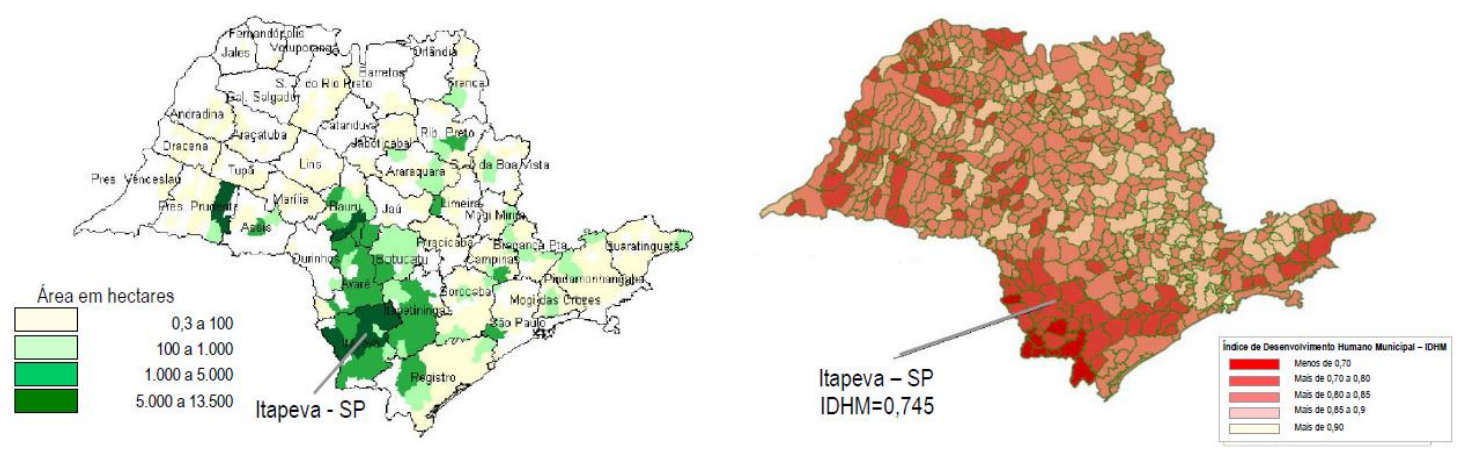

Figura 6 Mapa do Estado de São Paulo indicando as áreas com plantios índices de desenvolvimento humano (IDH) por cidade.

Fonte: O verde em São Paulo. Revista Fapesp, nº1, 2003 e SEADE - Condições de Vida, 2006.

O Grupo de Pesquisa de Habitação e Sustentabilidade do IAU - USP /UFSCar (HABIS) iniciou suas atividades de pesquisa e intervenção na realidade dessa região unindo a demanda habitacional rural do município de Itapeva e a disponibilidade da madeira como matéria-prima para a construção das mesmas. A partir desta demanda e desafio o HABIS iniciou processo em conjunto com parceiros e comunidade para construção do projeto de políticas públicas denominado 
"Habitação social em madeira de reflorestamento como alternativa econômica para usos múltiplos da floresta", financiado pela FAPESP (processo no 98/14124-1). O projeto abrangia três áreas de estudo:

1) reposição florestal: agricultura familiar e criação e fortalecimento da articulação entre as famílias, Estado, cadeia produtiva da madeira e assessoria;

2) habitação social: participação das famílias, criação e fortalecimento da articulação entre as famílias, Estado, cadeia produtiva da madeira e assessoria e a inovação de técnicas e de formas de gestão;

3) geração de trabalho e renda: economia solidária e inovação de técnicas e de gestão.

Segundo Ino (1999) o projeto teve como objetivo, contemplar o potencial madeireiro da região sudoeste do Estado de São Paulo, com a implantação de atividades sócio-econômicas compatíveis com a vocação local, por meio da formação de parcerias com instituições públicas e privadas com interesse no desenvolvimento da cadeia produtiva de habitação em madeira de plantios florestais, tendo em vista a melhoria da qualidade de vida da população e redução dos custos de moradias, incrementando-se a atividade econômica da região com 0 aumento de oportunidades para a geração de trabalho e renda.

Após momentos críticos durante a fase de formulação de políticas públicas a partir do envolvimento dos diversos agentes locais em 1999, o grupo de pesquisa HABIS procurou ampliar as metas de intervenção por meio de ampla divulgação junto aos municípios vizinhos. O projeto de políticas públicas teve condições favoráveis na implementação de algumas das metas previstas, principalmente relativas à habitação social e geração de trabalho e renda, com a demanda por construção de novas unidades habitacionais no Assentamento Rural Pirituba II, localizado nos municípios de Itaberá e Itapeva, que foi levada para o grupo HABIS através de uma lista de famílias do assentamento que reivindicavam moradias para o Instituto de Terras do Estado de São Paulo (ITESP). Em fevereiro de 2004, as famílias desse assentamento foram contempladas com um financiamento para a construção de 49 unidades habitacionais dentro do Programa de Subsídio à Habitação de Interesse Social (PSH), vinculado ao Ministério das Cidades, a partir de um convênio entre Caixa Econômica Federal (CEF) e Incra (Instituto de Colonização e Reforma Agrária) ${ }^{16}$.

O desafio colocado nesse processo de construção foi a redução de custos da habitação, procurando-se enquadrar um projeto com maior área e melhor qualidade dentro dos valores

${ }^{16}$ Os detalhes referentes ao projeto de políticas públicas, do encontro entre as famílias e assessores do Inovarural e as estratégias utilizadas a fim de mediar as relações entre diferentes lados foram detalhadas na dissertação de mestrado de SHIMBO, L. Z. (2004). "A casa é o pivô: mediações entre o arquiteto, o morador e a habitação rural". EESC - USP. 
de financiamentos públicos para habitação social, além das metas já colocadas pelo projeto de políticas públicas nas áreas de habitação e geração de renda. Considerando-se então a grande quantidade de plantios florestais da região, optou-se pela madeira como alternativa de material construtivo para a produção de componentes para habitação social, por ser um material disponível, renovável e por proporcionar maior qualidade ao produto.

Deste processo iniciou-se as atividades da Marcenaria Coletiva de Mulheres que possibilitou, a partir do emprego do trabalho dos próprios assentados, a produção de componentes para habitação como componentes para estrutura de cobertura, batentes, portas e folhas de janelas de diferentes tipologias. ${ }^{17}$

Tabela 9 Componentes em madeira para habitação de interesse social produzidos ao longo do processo de incubação da marcenaria

\begin{tabular}{|c|c|c|c|}
\hline Componente & Descrição & $\begin{array}{l}\text { Momento da } \\
\text { marcenaria }\end{array}$ & $\begin{array}{l}\text { Fontes de } \\
\text { evidência }\end{array}$ \\
\hline Esquadrias Pirituba & $\begin{array}{l}144 \text { esquadrias de madeira de eucalipto } \\
\text { - } 207,36 \mathrm{~m}^{2} \text { de janelas de 1,20 x 1,20 m } \\
\text { da tipologia de abrir de vidro com } 144 \\
\text { batentes de eucalipto de } 1,20 \times 1,20 \mathrm{~m}\end{array}$ & MOMENTO 3 & LAVERDE (2007) \\
\hline Sistema cobertura Pirituba & $\begin{array}{l}\text { Componente de cobertura composto por } \\
\text { tábuas de Pinus spp de } 3^{\mathrm{a}} \text { qualidade } \\
\text { justapostas; } 2,86 \mathrm{~m}^{3} \text { de madeira / casa }\end{array}$ & MOMENTO 3 & $\begin{array}{l}\text { EGAS (2008) } \\
\text { VALLE (2011) }\end{array}$ \\
\hline Esquadrias Sepé & $\begin{array}{l}201 \text { esquadrias de madeira de eucalipto } \\
\text { do tipo de abrir de vidro; } 289,44 \mathrm{~m}^{2} \text { de } \\
\text { folhas de } 0,60 \times 1,20 \text { m com } 201 \text { batentes } \\
\text { de eucalipto de } 1,20 \times 1,20 \mathrm{~m}\end{array}$ & MOMENTO 5 & LEITE (2008) \\
\hline Esquadrias Sepé & $\begin{array}{l}105 \text { esquadrias de madeira de eucalipto } \\
\text { do tipo mexicana de abrir; } 151,20 \mathrm{~m}^{2} \text { de } \\
\text { janelas de } 0,60 \times 1,20 \mathrm{~m} \text { com } 105 \\
\text { batentes de eucalipto de } 1,20 \times 1,20 \mathrm{~m}\end{array}$ & MOMENTO 5 & LEITE (2011) \\
\hline Esquadrias Sepé & $\begin{array}{c}55 \text { esquadrias de madeira de eucalipto } \\
\text { do tipo veneziana de abrir; } 79,20 \mathrm{~m}^{2} \text { de } \\
\text { janelas de } 0,60 \times 1,20 \mathrm{~m} \text { com } 55 \text { batentes } \\
\text { de eucalipto de } 1,20 \times 1,20 \mathrm{~m}\end{array}$ & MOMENTO 5 & ROMERO (2008) \\
\hline
\end{tabular}

17 Descrição detalhada dos momentos e estratégias adotadas para formação da marcenaria pode ser encontrada em LAVERDE, (2007) 
Segundo as marceneiras em entrevista consedida a Cherfem (2009) a ideia de montar uma marcenaria surge para:

[...]baratear o custo das casas fazendo portas, batentes e a cobertura alternativa. Quinze pessoas deram o nome para trabalhar, mas só três pessoas acreditaram na marcenaria. Foi muito difícil começar do nada, hoje já está bem melhor. Algumas pessoas ajudaram na limpeza do barracão, no começo não sabíamos nada, nem conhecíamos a máquina, nem pensava em trabalhar numa marcenaria, porque a gente só trabalhava na roça (Camélia).

O excerto acima demonstra o processo inicial de envolvimento dos assentados na marcenaria. Ilustra a ampla aceitação da proposta, mas evidencia a baixa continuidade ao longo da implementação da proposta. Desta forma cabe identificar e caracterizar o grupo que se manteve ao longo do processo da marcenaria, de maneira a aumentar a nossa compreensão sobre a constituição da identidade social da Marcenaria Coletiva de Mulheres.

\subsection{Caracterização das Mulheres da Marcenaria Coletiva}

Como maneira de ampliar a compreensão sobre a Marcenaria de Mulheres este estudo utilizou as teorias de Idenditade Social (TAJFEL, 1984) como recurso analítico para identificar e caracterizar um conjunto de variáveis possivelmente importantes acerca do grupo e fenômeno social estudado que melhor se enquadram na perspectiva de emancipação dos trabalhadores ensejada pelos EESs.

De acordo com Tajfel (1984) na perspectiva intergrupal da identidade social, a caracterização social é um sistema de orientação que ajuda a criar e definir o posto do indivíduo na sociedade. Como maneira de ampliar o escopo do estudo sobre os desafios enfrentados por um grupo de mulheres que se mobilizaram para a produção autogestionária de componentes para habitação procurou-se conhecer os significados e as práticas construídas na dinâmica entre endogrupo (identidade construída a partir da comparação social positiva) e exogrupo (o outro, como "não-eu", nãonós" que tem uma identidade social sobre o endogrupo negativa).

A Marcenaria Coletiva de Mulheres durante a realização desta pesquisa se configurou como um EES, em processo de incubação incluído no Sistema de Informações em Economia Solidária da Secretaria Nacional de Economia Solidária (SIES/SENAES) desde 2005. Seus membros são mulheres com mais de 50 anos, agricultoras familiares, moradoras de duas agrovilas (agrovila um e quatro) do assentamento rural mais antigo do estado de São Paulo, cujas características estão sistematizadas na Tabela 2. 
Tabela 10 Caracterização das marceneiras.

\begin{tabular}{|c|c|c|c|c|c|c|c|}
\hline & $\begin{array}{c}\text { Ano de } \\
\text { inserção na } \\
\text { marcenaria }\end{array}$ & Escolar & idade & $\begin{array}{l}\text { Estado } \\
\text { Civil }\end{array}$ & $\begin{array}{l}\text { Número } \\
\text { de filhos }\end{array}$ & $\begin{array}{l}\text { Número } \\
\text { de netos }\end{array}$ & $\begin{array}{l}\text { Maridos necessitam de } \\
\text { cuidados médicos } \\
\text { periódicos? }\end{array}$ \\
\hline & & 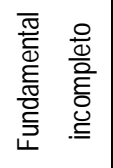 & 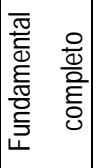 & & & & \\
\hline Crisântemo & 2004 & $x$ & & casada & 1 & 1 & $\operatorname{sim}$ \\
\hline Sempre-viva & 2004 & $x$ & & casada & 3 & 1 & não \\
\hline Dália & 2004 & $x$ & & casada & 3 & 2 & $\operatorname{sim}$ \\
\hline Begônia & 2005 & & $x$ & casada & 1 & 1 & sim \\
\hline Camélia & 2009 & & $x$ & casada & 2 & - & não \\
\hline
\end{tabular}

A comunidade rural onde o estudo foi realizado existe há 27 anos e é constituída por aproximadamento 500 famílias divididas em sete agrovilas. Quatro das cinco mulheres que são integrantes da marcenaria nasceram na área rural, áreas vizinhas a comunidade. Em função de casamento ou imigração da família, participaram do processo de ocupação das terras no início da década de 1980 deste a fase de acampamento até sua consolidação como assentamento de reforma agrária. As mulheres não têm histórico algum de trabalho com serviços qualificados de marcenaria tendo o aprendizado sido realizado na prática do dia-a-dia com um apoio inicial de um instrutor, marceneiro aposentado com 30 anos de marcenaria, porém sem experiência anterior com ensino do ofício.

Tabela 11 Caracterização das marceneiras a partir de olhares de dentro (endogrupo) e de olhares de fora do grupo (exogrupo).

\begin{tabular}{|c|c|c|c|c|}
\hline & GRUPO & REPRESENTAÇÕES & EVIDÊNCIAS & FONTE \\
\hline 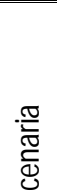 & & Batalhadoras & $\begin{array}{l}\text { cuidam da casa, cuidam da roça do entorno da casa, } \\
\text { cuidam dos maridos, cuidam dos netos, são mães, } \\
\text { conduzem a marcenaria, viabilizaram a construção } \\
\text { das casas no assentamento com as trocas } \\
\text { realizadas. }\end{array}$ & $\begin{array}{l}\text { Vídeos } \\
\text { INOVARURAL } \\
\text { acervo HABIS }\end{array}$ \\
\hline 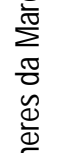 & Endogrupo & Dispostas & $\begin{array}{l}\text { O relato de todas as marceneiras do tempo e } \\
\text { ditância percorrida de suas casas até a marcenaria } \\
(6 \mathrm{Km}) \text { por todos estes anos indica uma disposição e } \\
\text { motivação grande para o trabalho na marcenaria. }\end{array}$ & $\begin{array}{l}\text { Vídeos } \\
\text { INOVARURAL } \\
\text { acervo HABIS }\end{array}$ \\
\hline$\overline{\overline{\bar{D}}}$ & & Exemplos de superação & $\begin{array}{l}\text { A inserção de novas pessoas na marcenaria a partir } \\
\text { do relato que elas fazem das conquistas delas } \\
\text { possibilita esta afirmação de exemplo para pessoas } \\
\text { do assentamento. }\end{array}$ & $\begin{array}{l}\text { Observação direta } \\
\text { do pesquisador }\end{array}$ \\
\hline
\end{tabular}




\begin{tabular}{|c|c|c|c|}
\hline \multirow{3}{*}{ Exogrupo } & Caseiras & $\begin{array}{l}\text { Mulher não pode trabalhar fora de casa e o apoio } \\
\text { para realização de trabalhos diferentes da lavoura é } \\
\text { mínimo ou inexistente; }\end{array}$ & CHERFEM (2009) \\
\hline & Ingênuas & $\begin{array}{l}\text { experiências frustradas anteriores de trabalho } \\
\text { associado vividas por seus maridos. Eles espelham } \\
\text { esta possibilidade de frustração na marcenaria as } \\
\text { considerando ingênuas pelo fato de imaginarem que } \\
\text { isto poderá dar certo já que com eles a experiência } \\
\text { foi ruim. }\end{array}$ & CHERFEM (2009) \\
\hline & Brigonas & $\begin{array}{l}\text { Histórico de conflitos abertos entre as marceneiras e } \\
\text { conversas paralelas destas situações no } \\
\text { assentamento. }\end{array}$ & $\begin{array}{l}\text { Observação direta } \\
\text { do pesquisador }\end{array}$ \\
\hline
\end{tabular}

Além desta caracterização a partir da definição do endogrupo e do exogrupo, outros elementos dentro da estrutura do grupo podem ser analisados como: 1) Elementos estáticos - a) Tamanho; b) Homogeneidade e heterogeneidade; c) Posição e status e d) Normas e 2) Elementos dinâmicos - a) Coesão; b) Afiliação; c) Cultura; d) Clima grupal e e) Rol. A análise a partir destes elementos facilitará a compreensão dos fatores que potencializam relações mais duradouras na marcenaria.

Tabela 12 Estrutura do grupo a partir de elementos estáticos e dinâmicos.

\begin{tabular}{|c|c|c|c|}
\hline \multicolumn{2}{|r|}{ ELEMENTOS } & DESCRIÇÃO & VERIFICAÇÃO \\
\hline \multirow{4}{*}{ 忌 } & | Tamanho & $\begin{array}{l}\text { Quantidade de pessoas e } \\
\text { suas características físicas } \\
\text { ao longo de um tempo. }\end{array}$ & $\begin{array}{l}\text { Atualmente cinco mulheres, sendo quatro mulheres pioneiras e } 10 \\
\text { jovens ao longo de todo processo de formação sendo que, nesta } \\
\text { categoria, o rodízio é grande e apenas um jovem se manteve por } \\
\text { mais tempo na marcenaria. }\end{array}$ \\
\hline & $\begin{array}{l}\text { Homogeneidade } \\
\text { e } \\
\text { heterogeneidade }\end{array}$ & 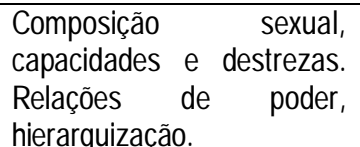 & $\begin{array}{l}\text { Compõem a marcenaria cinco mulheres com capacidades distintas } \\
\text { mas que se complementam. Não há relações de poder explicitadas, } \\
\text { no entanto, é possível verificar um peso maior nas falas das } \\
\text { pioneiras em relacão as que se inseriram depois. }\end{array}$ \\
\hline & Posição e status & $\begin{array}{l}\text { Posição dentro do grupo } \\
\text { seja na hierarquia seja } \\
\text { como liderança, como } \\
\text { modelo ou mediador. }\end{array}$ & $\begin{array}{l}\text { É possível notar que atividades que demandam habilidades } \\
\text { relacionadas a graus maiores de escolaridade como, por exemplo, } \\
\text { elaborar orçamento, é assumido e delegado às marceneiras } \\
\text { Begônia e Camélia, no entanto, o resultado é sempre questionado } \\
\text { pelas pioneiras trazendo efeitos na confiança e credibilidade no } \\
\text { grupo. }\end{array}$ \\
\hline & Normas & $\begin{array}{l}\text { Marco de referência do } \\
\text { grupo. Existem normas } \\
\text { explicitas e implicitas. }\end{array}$ & $\begin{array}{l}\text { A maioria das normas na marcenaria são implícitas sendo que seu } \\
\text { regimento interno foi elaborado em } 2005 \text { e não sofreu revisões que } \\
\text { explicitassem as normas vigentes. A etapa de monitoramento das } \\
\text { horas trabalhadas e papéis assumidos por encomenda é a norma } \\
\text { mais explicitada e acordada no entanto, há conflitos no momento da } \\
\text { divisão dos ganhos. }\end{array}$ \\
\hline \multirow{2}{*}{ 总 } & Coesão & $\begin{array}{l}\text { Grau em que os membros } \\
\text { de um grupo se encontram } \\
\text { atraídos e desejam } \\
\text { permanecer assim. }\end{array}$ & $\begin{array}{l}\text { O grau de coesão do grupo é baixo tendo em vista, que diante da } \\
\text { atividade produtiva uma marceneira prefere a produção de } \\
\text { pequenos objetos de madeira, duas preferem a produção de móveis } \\
\text { grandes e esquadrias, uma é indiferente e outra se dispõe a } \\
\text { produzir o que gerar mais renda. }\end{array}$ \\
\hline & Afiliação & $\begin{array}{l}\text { Nível de identificação de } \\
\text { um membro com seu grupo } \\
\text { analisado a partir de dois } \\
\text { aspectos: atração, o que } \\
\text { incita a pertencer ao grupo }\end{array}$ & $\begin{array}{l}\text { O que se configura como identidade, para todas, é a necessidade } \\
\text { de complementação da renda e a continuidade de uma atividade } \\
\text { que legitime sua capacidade de produzir e gerar renda. Para } \\
\text { algumas a manutenção de um espaço de encontro para conversas } \\
\text { e amizade. Em alguma medida pessoas que tiverem a mesma }\end{array}$ \\
\hline
\end{tabular}




\begin{tabular}{|c|c|c|}
\hline & $\begin{array}{l}\text { e aceitação do grupo a } \\
\text { incluir nova pessoa. }\end{array}$ & $\begin{array}{l}\text { motivação e se forem mulheres, especialmente, ou jovens são } \\
\text { inseridas na marcenaria. }\end{array}$ \\
\hline Cultura & $\begin{array}{l}\begin{array}{l}\text { Marco de } \\
\text { horizontal }\end{array} \\
\begin{array}{r}\text { referência } \\
\text { (valores, }\end{array} \\
\text { crenças). } \\
\text { simbólicos } \\
\text { dentro do grompartilhados } \\
\text { configuram que se } \\
\text { consolidação das relações } \\
\text { grupais. }\end{array}$ & $\begin{array}{l}\text { Não há uma referência horizontal na marcenaria a não ser quando } \\
\text { há condições favoráveis para a geração de trabalho e renda } \\
\text { (encomendas periódicas, estoque de madeira seca e de qualidade, } \\
\text { insumos no estoque e equipamentos revisados). Nesta situação } \\
\text { favorável é notável que se geram comportamentos compatíveis com } \\
\text { os princípios da autogestão como divisão equilibrada do trabalho, } \\
\text { cumprimento dos prazos, papéis e responsabilidades. }\end{array}$ \\
\hline Clima grupal & $\begin{array}{l}\text { Avaliação que os membros } \\
\text { fazem sobre a cultura do } \\
\text { grupo. Sensação de bem } \\
\text { estar ou mal estar dentro do } \\
\text { grupo. }\end{array}$ & $\begin{array}{l}\text { Os conflitos interpessoais aparecem mais fortemente quando não } \\
\text { há encomendas. Conflitos pessoais que existem desde a formação } \\
\text { do assentamento ressurgem com facilidade quando há disputas de } \\
\text { interesses no ambiente de trabalho. Assim, a sensação de mal estar } \\
\text { está relacionada diretamente a inexistência das condições } \\
\text { necessárias para a produção. }\end{array}$ \\
\hline Rol & $\begin{array}{l}\text { Padrão de conduta } \\
\text { associada com uma pessoa } \\
\text { pelo fato de ocupar uma } \\
\text { determinada posição. }\end{array}$ & $\begin{array}{l}\text { Pessoas que recebem aposentadoria se encontram em uma } \\
\text { posição mais favorável que outras na marcenaria. Esta situação } \\
\text { gera constrangimentos a partir do momento que esta pessoa passa } \\
\text { a escolher as encomendas em que quer participar }\end{array}$ \\
\hline
\end{tabular}

A construção de uma estrutura mais horizontal de relações de poder, característica importante de uma produção baseada nos princípios e valores da autogestão, depende de um equilíbrio dinâmico de relações intragrupal e seus elementos estáticos e dinâmicos que são influenciados diretamente pelas interações intergrupais.

\subsection{Descrição dos momentos do processo de incubação da Marcenaria Coletiva de Mulheres}

Para descrever o processo de incubação da marcenaria utilizamos duas ferramentas que nos facilitaram a identificação das variáveis que interferiram no processo autogestionário no empreendimento. Uma ferramenta utiliza os fundamentos teóricos e metodológicos do método de incubação da INCOOP UFSCar e outra ferramenta é a linha do tempo que traz uma síntese dos momentos do processo de incubação com foco nos produtos gerados e estratégias gerais adotadas.

\subsubsection{Linha do tempo do processo de incubação}

A Marcenaria Coletiva de Mulheres iniciou suas atividades em 2002 a partir da provocação de um grupo de pesquisa que anunciava as oportunidades da produção de componentes para habitação em madeira aproveitando o potencial da região relacionado às potencialidades do trabalho coletivo para diminuição dos custos da produção das casas. Assim, a marcenaria inicia suas atividades como um grupo interessado atender as necessidades de produzir componentes construtivos de madeira para as 49 casas construídas no INOVARURAL. Nas discussões iniciais do projeto com as famílias beneficiadas pela construção das casas, foi apresentada, a importância de integrar as atividades de construção, com a possibilidade de geração de trabalho e renda, buscando assim, 
romper com a forma tradicional de autoconstrução comumente encontrada nas habitações do campo. A proposta era, inicialmente, reduzir custos com qualidade construtiva, utilizando a madeira (disponibilidade de pinus e eucalipto) da região, e principalmente criar condições facilitadoras e oportunidades para geração de trabalho e renda para as famílias do assentamento. Uma das questões discutidas foi à produção de componentes construtivos (portas, janelas e estrutura de cobertura) em uma marcenaria coletiva autogestionária, formada por integrantes das famílias do próprio assentamento. Dessa forma, a ideia foi discutida com as famílias envolvidas no projeto INOVARURAL e coletivamente decidiu-se pela formação da marcenaria que deveria ser composta por representantes dos grupos das 49 famílias.

No segundo momento foram realizadas reuniões para sensibilização dos interessados em se organizar coletivamente para a fabricação dos componentes para construção das casas, aparecendo, após a sensibilização, a necessidade de capacitação em serviços qualificados de marcenaria. Após adesão livre, espontânea e esclarecida de cinco mulheres e quatro homens iniciaram-se a capacitação desses interessados na Escola Superior de Agronomia da USP (ESALQ), em Piracicaba / SP, distante $300 \mathrm{~km}$ do assentamento. Foram ofertadas para esta capacitação as instalações do Laboratório de Madeira, um pesquisador e um técnico, especialistas em processamento de madeira. Para esta capacitação no laboratório em Piracicaba foram encaminhados os quatro homens, por um período de quatro dias consecutivos, sendo que os mesmos mais tarde desistiriam de participar da formação da marcenaria.

De acordo com a autora Laverde (2007), a desistência da participação dos homens do assentamento foi devido ao fato desses homens assumirem tarefas ligadas à lavoura e, naquele período, ao processo de mutirão no canteiro de obras na construção das 49 moradias.

Devido a desistências de alguns membros da marcenaria, a Assembleia do projeto INOVARURAL decidiu indicar representantes para assumir todas as atividades da marcenaria, assim 0 grupo passaria ter nove membros para facilitar a troca de serviços da marcenaria com as atividades de construção no canteiro. A partir deste momento entrou em cena um marceneiro instrutor, remunerado com recursos do projeto de pesquisa coordenado pelo HABIS e com a parceria da INCOOP. Aconteceu neste momento também a inserção de jovens cursando ensino médio, interessados na capacitação em marcenaria. Esta modalidade de participação, no entanto, gerou inúmeros conflitos. A participação dos representantes foi pouca, grande rotatividade entre os participantes, ausência de representantes nas atividades, dificuldades de indicação de representantes, conflitos interpessoais de várias naturezas, terceirização de serviços e conflitos de gênero. O grupo mais participativo encaminhou à Assembleia 
uma proposta para assumir as atividades da marcenaria. Esta proposta foi aceita. O grupo, composto por três mulheres passou a ser denominado Grupo da Marcenaria, iniciou suas atividades com 0 levantamento dos fornecedores de madeira da região, o teste das máquinas, a capacitação do grupo mais assíduo para a operação das máquinas e a fabricação de cavaletes e mesas para a marcenaria.

A partir de 2004 a continuidade da marcenaria se deu através do grupo de pioneiras e da inserção dos jovens enquanto empreendimento coletivo autogestionário. Terminado o compromisso com o projeto Inovarural, o grupo da marcenaria decidiu continuar o trabalho realizado partindo para a busca de encomendas que garantam uma renda inicial para o grupo enquanto se organiza para a formação de um empreendimento coletivo autogestionário. Para a continuidade foi necessária a intensificação das atividades de gestão, autogestão e capacitação técnica seguindo o método de incubação construído com o grupo.

Ao longo do processo de formação e consolidação da Marcenaria Coletiva de Mulheres como empreendimento econômico solidário foram levantados algumas condições específicas indicadas como necessárias para o desenvolvimento pleno do grupo que seguem:

a) continuidade da formação em Economia Solidária apostando que seus membros se constituam como multiplicadores da experiência do trabalho coletivo e autogestionário;

b) constituição e manutenção de um fundo coletivo e definição de direitos no trabalho;

c) composição e apropriação do custo das encomendas;

d) distribuição dos ganhos, perdas e recursos financeiros;

e) estratégias do grupo para a sua ampliação e inserção de jovens na marcenaria.

f) estratégias do grupo para acesso, produção e monitoramento dos aspectos tecnológicos envolvidos no processo de produção de componentes de madeira para habitação.

É importante ressaltar que a incubação da marcenaria contou com diversos parceiros. Estas parcerias possibilitaram a organização de um arranjo local de parceiros da marcenaria. Em 2010, com o processo de aproximação do Grupo de Pesquisa em Produtos Lignocelulósicos do Campus experimental da Universidade Estadual de São Paulo (LIGNO UNESP) foi possível aumentar a proximidade dos assessores a marcenaria (a grande distância dos assessores da INCOOP e do HABIS a marcenaria tornou-se grande obstáculo na incubação do empreendimento). Esta estratégia trouxe novas desafios a equipe de assessores da INCOOP e do HABIS. O foco dos assessores foi voltado para a formação dos membros do grupo de pesquisa Ligno. Como desafios desta formação temos: 
- 0 aumento da compreensão da equipe do LIGNO sobre os valores e princípios da economia solidária;

- o aumento da compreensão do papel da universidade e das possibilidades de construção do conhecimento simultaneamente a ação na realidade com a formação de todos os envolvidos;

- a construção de relações de confiança entre os assessores do LIGNO e as marceneiras.

A figura 5 ilustra os momentos do processo de incubação da marcenaria. 0 exame da linha do tempo possibilitou identificar algumas variáveis que interferiram nos processos estudados e, ainda, possibilitou comparar a evolução da autogestão ao longo dos momentos do processo de incubação da marcenaria.

Podemos notar na figura as estratégias gerais nos quadros verdes a esquerda perpassando os momentos da marcenaria (descritos na linha abaixo das fotos) com a perspectiva de ampliar a inserção de jovens no grupo e promover o desenvolvimento do território por meio da atuação da marcenaria seja como incentivadora da criação de novos empreendimentos solidários no assentamento seja participando das instâncias do movimento da economia solidária. 


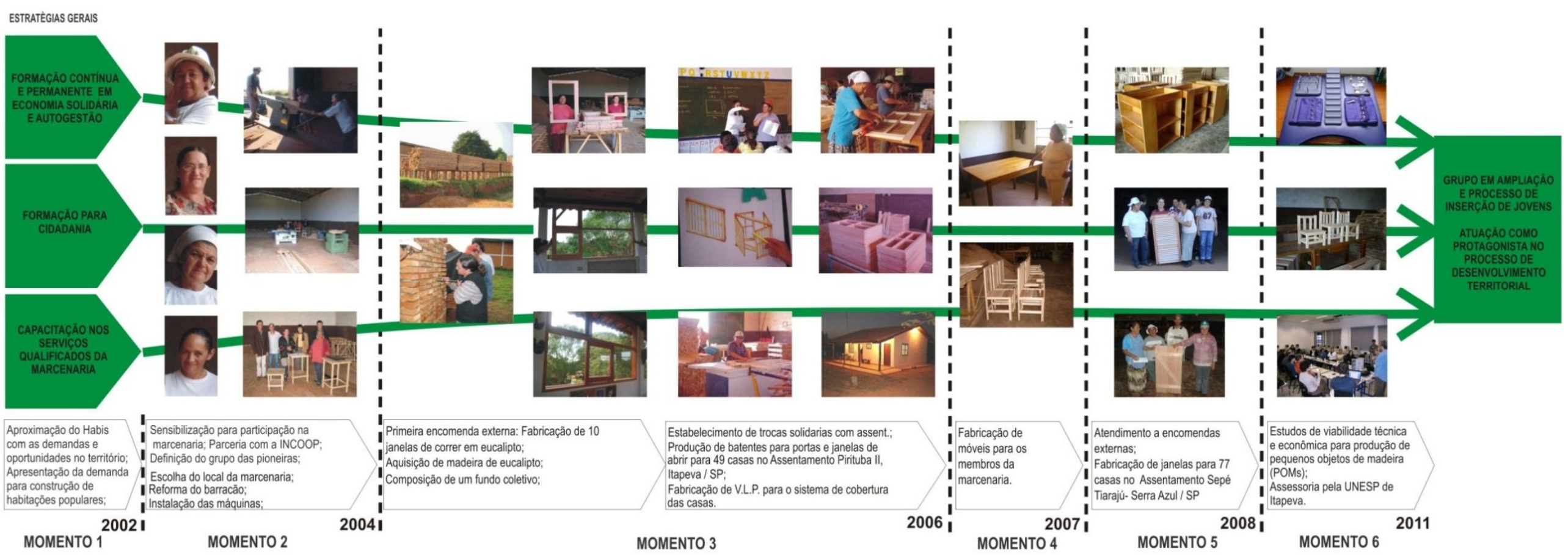

Figura 7 Linha do tempo de formação da Marcenaria Coletiva de Mulheres, Assentamento Rural Pirituba II, Itapeva/SP.

Fonte: Dados da pesquisa. 


\subsubsection{Caracterização dos momentos da incubação da marcenaria a partir do método de incubação proposto pela INCOOP com base na Análise do Comportamento}

Uma primeira sistematização do processo de incubação (a partir do método de incubação) foi realizado em 2007 quando foi possível identificar variáveis relevantes neste processo para orintar a atuação dos agentes de incubação em seu trabalho de intervenção. A identificação destas variáveis possibilitará indicar as condições essenciais, as dificuldades e os limites da autogestão e da adequação sociotécnica.

São apresentadas, a seguir, informações sobre características das ações da incubadora, considerando aquelas previstas no processo de incubação até 2007, bem como resultados observados a partir da atuação concreta da INCOOP em relação ao marcenaria.

\begin{tabular}{|c|c|}
\hline Características de atuação da Incubadora & $\begin{array}{l}\text { Resultados relacionados à forma de ação dos } \\
\text { assessores }\end{array}$ \\
\hline $\begin{array}{l}\text { A demanda para a formação de uma marcenaria } \\
\text { coletiva foi apresentada pelo HABIS, formado por } \\
\text { pesquisadores de duas universidades públicas } \\
\text { brasileiras, durante a construção de moradias para } \\
\text { agricultores familiares com baixa renda, em um } \\
\text { assentamento rural distante } 400 \mathrm{~km} \text { da incubadora. } \\
\text { A proposta da marcenaria surgiu, do Grupo de } \\
\text { Pesquisa, como possibilidade de diminuição dos } \\
\text { custos da habitação e oportunidades para geração } \\
\text { de trabalho e renda na fabricação de componentes } \\
\text { em madeira (janelas, portas e componentes para } \\
\text { sistema de cobertura). O HABIS solicitou a } \\
\text { INCOOP apoio na incubação da Marcenaria } \\
\text { Coletiva de Mulheres, assim como, parcerias para } \\
\text { obter financiamento da pesquisa com recursos } \\
\text { para a contratação de um coordenador de } \\
\text { incubação, bolsista de graduação e um } \\
\text { marceneiro-instrutor, bem como para } \\
\text { deslocamento da equipe até o assentamento. }\end{array}$ & $\begin{array}{l}\text { Os critérios utilizados para acolhimento da demanda } \\
\text { foram: compatibilidade da população alvo com aquela } \\
\text { prevista pela incubadora, possibilidade de uma equipe } \\
\text { mínima a partir de financiamento obtido junto à agência } \\
\text { de fomento, estudos preliminares sobre a viabilidade } \\
\text { do empreendimento, disposição do grupo a ser } \\
\text { incubado em constituir um empreendimento coletivo, } \\
\text { contatos periódicos com o grupo interessado e } \\
\text { possibilidade de construir projeto para a busca de } \\
\text { recursos. Diante dos critérios e recursos levantados } \\
\text { para a incubação, a demanda foi aceita. }\end{array}$ \\
\hline \multicolumn{2}{|c|}{$\begin{array}{l}\text { Classe 2: Quanto à identificação da população em potencial para formação de } \\
\text { empreendimento solidário }\end{array}$} \\
\hline Características de atuação da Incubadora & $\begin{array}{l}\text { Resultados relacionados à forma de ação da } \\
\text { Incubadora }\end{array}$ \\
\hline
\end{tabular}


O Grupo da marcenaria se constituiu como consequência de um processo maior que era a construção de 49 moradias em regime de mutirão assistido no assentamento rural onde, paralelamente, seria implantada a marcenaria coletiva por meio de um processo de sensibilização dos mutirantes para a formação da atividade. Sobre o desejo/ sonho das pessoas que se interessaram de, mesmo concluindo os trabalhos de preparo de componentes para as casas do assentamento, continuar trabalhando na marcenaria, a INCOOP em conjunto com o HABIS, se propôs a assessorar o grupo obtendo recursos financeiros para contratação de um marceneiro instrutor e todo o processo de incubação. O grupo atual (junho 2007) é composto por quatro mulheres assentadas de baixa renda, com idade entre $40 \mathrm{e}$ 50 anos que fazem parte do núcleo inicial que contava ainda com 5 homens assentados. $O$ grupo em sua fase inicial contou com um marceneiro instrutor que desligou-se em 2006. Foram montadas em conjunto com o Grupo estratégias para a inserção de jovens do assentamento na marcenaria, atualmente (junho de 2007) são três jovens na marcenaria sendo duas mulheres.
Grupo composto por mulheres, com baixa escolaridade, com pouca remuneração e com alta motivação nos serviços em marcenaria - atividade comumente executada predominantemente por homens - e 3 jovens sendo um adolescente de 18 anos com ensino médio completo que participou de todas as etapas da incubação até então, com alta motivação para os serviços da marcenaria, alta capacidade de liderança e que participa efetivamente dos ganhos do empreendimento e duas adolescentes em processo de inserção com capacitações em cooperativismo e serviços técnicos da marcenaria.

\section{Classe 3: Quanto à caracterização dos diferentes envolvidos no processo de incubação}

\begin{tabular}{l|l}
\hline Características de atuação da Incubadora & Resultados relacionados à forma de ação da
\end{tabular} Incubadora

A INCOOP, em conjunto com o HABIS, privilegiou, inicialmente, o cumprimento dos acordos sobre as condições e prazos para término da fabricação dos componentes para que fossem obtidos dados iniciais do andamento da atividade e dos envolvidos na produção. Estes dados foram obtidos de forma sistemática durante as reuniões e contatos informais. A compreensão da cadeia produtiva em que estão inseridos é abordada pela equipe assessora como condição para continuidade e autonomia do empreendimento. A caracterização dos diferentes parceiros foi realizada em conjunto com o Grupo, para que o mesmo torne-se capaz de identificar as motivações e contrapartidas oferecidas pelos parceiros. Pretende-se explicitar $e$ sistematizar a atuação de cada parceiro em relação a: grau de interesse, recursos disponibilizados, estratégias utilizadas e dificuldades encontradas com cada parceiro para aumentar a compreensão dos membros da marcenaria, tendo em vista a aprendizagem de negociação e busca de outras parcerias.
Como resultados obtidos: grau de comprometimento de cada indivíduo com o coletivo, parcerias atuais identificadas em conjunto com o Grupo, levantamento das variáveis relevantes para o processo de negociação com diferentes parceiros. Como resultado esperado: Aumento da compreensão sobre o papel e contrapartidas de cada ator, aprendizagem para negociação com diferentes atores e busca de outros parceiros, compreensão conjunta de toda cadeia produtiva em que o Grupo está inserido. 


\section{Classe 4: Quanto à apresentação da economia solidária como possibilidade de organização para geração de trabalho e renda para população em potencial para formar um empreendimento solidário}

Características de atuação da Incubadora

Assim que o grupo apresentou o desejo/sonho de dar continuidade à marcenaria, de forma coletiva, a INCOOP promoveu várias reuniões com o grupo para apresentação da Economia Solidária como uma alternativa de trabalho. A inserção de uma pessoa, na equipe, na condição de facilitadora do processo de incubação, permitiu a inclusão do tema da Economia Solidária como centralidade nas discussões. Uma das atividades realizadas ocorreu de forma lúdica e utilizando técnicas de visualização com o grupo. Foi feita a partir de uma comparação com o modo de produção capitalista conhecido e vivenciado, buscando explorar uma linguagem popular possibilitando compreensão. A discussão ressurge diante das situações reais de produção, pois, se tem como princípio a educação na produção como espaço de discussão da economia solidária.

Classe 5: Quanto à organização inicial do grupo para tomada de decisão sobre formação (ou não) de empreendimento solidário

Características de atuação da Incubadora

Após a fabricação de esquadrias para as 49

moradias os membros do empreendimento (0 grupo) tomaram a iniciativa de definir uma atividade econômica. Coube a INCOOP iniciar um processo contínuo e permanente de informações sobre cooperativismo popular a fim de apresentar a economia solidária como opção viável para a organização e continuidade do empreendimento. Com a perspectiva de implantação de uma marcenaria coletiva, o grupo, em conjunto com a incubadora, definiu os recursos a serem solicitados para participação em editais públicos para obtenção de financiamentos. A INCOOP atua de modo a favorecer a consolidação do grupo e a formação para a Economia Solidária a partir da escolha da atividade econômica (fabricação de batentes para portas e/ou fabricação de batentes e folhas para janelas em madeira).
Resultados relacionados à forma de ação da Incubadora

Os resultados iniciais indicam um aumento de esclarecimentos ao grupo quanto um empreendimento pautado na economia solidária e com início de um conhecimento dos princípios cooperativistas. Até o momento é possível notar que o grupo toma decisões coletivas sobre diferentes aspectos, tendência para processamento coletivo de conflitos, organização coletiva do trabalho com rodízio nas diferentes a partir de critérios definidos pelo grupo e, além disso, monitoramento da fabricação de componetes de madeira para habitação. Como resultado esperado: inserção e formação de jovens para o cooperativismo e economia solidária e continuidade na formação em economia solidária, do grupo atual. atividades da marcenaria, utilização do fundo coletivo
Resultados relacionados à forma de ação da Incubadora

A marcenaria está em processo de consolidação dentro do assentamento, atendendo as demandas dos próprios assentados e obtendo grande receptividade de seus produtos já que, o Grupo entendeu a necessidade de se olhar para a realidade do território em que se insere aplicando formas de pagamento e preços diferenciados para os assentados e para moradores da cidade. Sendo assim, o grupo atual está tendendo a implantar uma Marcenaria Coletiva de Mulheres no assentamento rural com inserção de jovens como oportunidade de trabalho e renda e sustentabilidade, a longo prazo, da marcenaria.

O grupo, por meio da Incubadora, conseguiu financiamento sem reembolso para a melhoria da edificação e das condições de trabalho, deslocamento do grupo e da equipe da Incubadora, bolsas de aprendizagem para jovens do assentamento e contratação de profissional para a incubação.

\section{Classe 6: Quanto à elaboração de proposta de trabalho do grupo com a incubadora}

Características de atuação da Incubadora

\begin{tabular}{l|l} 
Resultados \\
Incubadora
\end{tabular}


O grupo tem participado das atividades propostas pela INCOOP, porém ainda não foi firmado acordo formal de atuação com o grupo e com os parceiros. A INCOOP objetiva abordar essa questão realizando acordos formais de atuação conjunta.
Os acordos construídos referem-se às relações internas para atividades coletivas e distribuição dos recursos do fundo coletivo. É esperado, como resultado, a construção coletiva e formalizada desses acordos.

\section{Classe 7: Quanto à formação dos membros do grupo para o cooperativismo e para a economia solidária}

Características de atuação da Incubadora

Desde sua origem, no contexto apresentado de construção das habitações, e no dia-a-dia da produção na marcenaria é buscada a operacionalização de alguns princípios do cooperativismo (adesão livre, voluntária e esclarecida, gestão compartilhada, tomada de decisão coletiva). A participação em feiras de Economia Solidária e visitas monitoradas a cooperativa de limpeza em São Carlos foram utilizados como instrumentos formação em cooperativismo

\section{Classe 8: Quanto à escolha de atividade econômica pelo grupo}

\begin{tabular}{|c|c|}
\hline Características de atuação da Incubadora & $\begin{array}{l}\text { Resultados relacionados à forma de ação da } \\
\text { Incubadora }\end{array}$ \\
\hline $\begin{array}{l}\text { O grupo da marcenaria apresenta a particularidade } \\
\text { de já ter se apresentado à INCOOP com uma } \\
\text { atividade econômica definida. Quando procurou a } \\
\text { INCOOP, além de mostrar interesse por uma } \\
\text { organização coletiva, demonstrou o interesse em } \\
\text { continuar como marcenaria, já que vinha } \\
\text { trabalhando neste ramo há mais de um ano e se } \\
\text { identificava com o trabalho, além da infraestrutura } \\
\text { inicial já adquirida. Após o término das casas do } \\
\text { assentamento deu-se continuidade a análise da }\end{array}$ & $\begin{array}{l}\text { Como resultado pode ser apontada a definição } \\
\text { coletiva sobre a atividade econômica que deverá } \\
\text { ocorrer na marcenaria. Essa escolha segue a vontade } \\
\text { do grupo, somada à viabilidade econômica da } \\
\text { atividade, levando em consideração o assentamento e } \\
\text { a região em que se encontra. Estudos preliminares e } \\
\text { a prática no aumento de demandas na marcenaria } \\
\text { indicam a viabilidade de batentes de madeira } \\
\text { (eucalipto) para portas e de janelas acessíveis para } \\
\text { população de baixa renda. }\end{array}$ \\
\hline
\end{tabular}

viabilidade dos componentes (portas e janelas) em madeira a serem produzidos na marcenaria viabilizando o levantamento de demandas na região, levantamento da oferta e preços de madeira serrada de plantios florestais, levantamento de ofertas de portas e janelas na região, articulação com fornecedores de madeira serrada.

\section{Classe 9: Quanto à capacitação técnica em relação ao serviço ou produção ofertado pelo} empreendimento

\begin{tabular}{|l|l|}
\hline Características de atuação da Incubadora & $\begin{array}{l}\text { Resultados relacionados à forma de ação da } \\
\text { Incubadora }\end{array}$ \\
\hline $\begin{array}{l}\text { O grupo da marcenaria já passou pela capacitação } \\
\text { técnica, inicialmente com o Grupo de Pesquisa e } \\
\text { um marceneiro-instrutor, em relação a algumas } \\
\text { atividades da marcenaria (interpretação de }\end{array}$ & $\begin{array}{l}\text { Grupo em capacitação para o aprimoramento do } \\
\text { processo produtivo de esquadrias e mobiliários } \\
\text { básicos. É verificada a necessidade de algumas } \\
\text { capacitações em conhecimentos básicos como }\end{array}$ \\
\hline
\end{tabular}




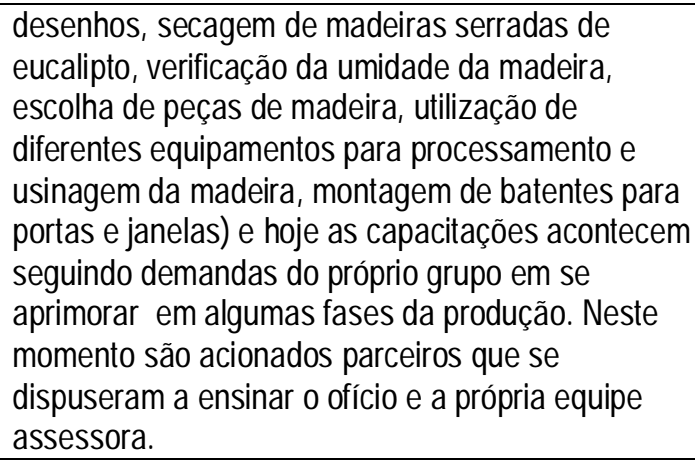

\section{Classe 10: Quanto à formação dos membros para a autogestão administrativa}

Características de atuação da Incubadora

As encomendas e demandas que surgem são tomadas pelo Grupo em conjunto com os assessores como momentos de aprendizagem de todo processo produtivo. Como por exemplo, em sua primeira encomenda externa ao assentamento de 10 janelas em madeira, 0 Grupo orientado pela equipe assessora assumiu as diferentes etapas do processo produtivo (elaboração de orçamento, negociação com demandante, aquisição de madeira serrada, fabricação e entrega da encomenda). matemática o que facilitaria a composição de custo de seus produtos.

\section{Resultados relacionados à forma de ação da} Incubadora

$O$ atendimento a uma encomenda de 10 janelas de madeira para uma residência no município em que se situa a Incubadora, permitiu a elaboração de proposta,, negociação com demandante, constituição de um fundo .

$O$ atendimento a demanda para fabricação de 252 batentes para portas e 240 janelas para 49 casas do Assentamento possibilitou o aumento da compreensão sobre a fabricação em escala, dados sobre produtividades e trocas mais solidária A perspectiva de continuidade do empreendimento coletivo indicou a necessidade de ações para a regularização da cessão de uso da edificação e das infra-estruturas da marcenaria eaquisição de equipamentos, ferramentas e madeira como posse coletiva do grupo.

\section{Classe 11: Quanto à elaboração de normas de funcionamento do empreendimento (estatuto e}

regimento interno)

Características de atuação da Incubadora

Foi elaborado, a partir da sensibilização da incubadora em reuniões com a marcenaria, um regimento interno a fim de lidar com os conflitos comuns ao trabalho em coletivo. Esta sensibilização visou a importância da explicitação de normas para o funcionamento da marcenaria (divisão de trabalho, quantificação de serviços, responsáveis por frentes de trabalho, processamento coletivo de conflitos interpessoais).
Resultados relacionados à forma de ação da Incubadora

Definição de algumas funções, responsáveis e procedimentos para processamento coletivo de conflitos interpessoais.

\section{Classe 12: Quanto à legalização do empreendimento}

\begin{tabular}{|l|l|}
\hline Características de atuação da Incubadora & $\begin{array}{l}\text { Resultados relacionados à forma de ação da } \\
\text { Incubadora }\end{array}$ \\
\hline Diante do aumento da visibilidade da marcenaria e & O entendimento por parte do Grupo que o processo \\
\hline
\end{tabular}




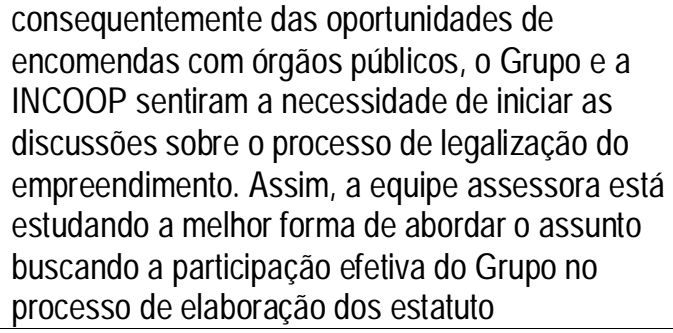

Classe 13: Quanto ao monitoramento do grupo

(a)

\section{Classe 14: Quanto à implantação do empreendimento}

Características de atuação da Incubadora

Alguns eixos estratégicos são assumidos para se monitorar a implantação efetiva do empreendimento: capacitação continua e permanente em autogestão, a inserção de jovens do próprio assentamento como estratégia de continuidade do empreendimento, aumento de encomendas, aumento e monitoramento do estoque de matéria prima no caso madeira proveniente de plantios florestais, capacitações em conhecimentos administrativos, técnicos e básicos e a sistematização de dados. Estes eixos indicam um caminho para a autogestão do empreendimento. Assim, operações são indicadas a fim de se atingir cada um dos objetivos e metas traçados pelos eixos estratégicos.

\section{Classe 15: Quanto ao apoio na implementação do empreendimento}

\begin{tabular}{l}
\hline Características de atuação da Incubadora \\
\hline A atuação da INCOOP na marcenaria tem \\
aumentado pois, o Grupo tem se mostrado mais \\
motivado e apto a demandar e solicitar ajuda o que \\
inicialmente não era uma ação rotineira. Assim, a \\
INCOOP tem agido no sentido de interagir o
\end{tabular}

de legalização é um processo importante da identidade do empreendimento e um grande passo para que esta etapa do empreendimento não seja encaminhada unicamente pelas oportunidades de aumento da produção e comercialização mas sim, pela oportunidade de se praticar os princípios do cooperativismo e da economia solidária e explicitá-las em um estatuto assinado e entendido por todos.

\section{Resultados relacionados à forma de ação da Incubadora}

No seu início, as reuniões eram relatadas apenas pela INCOOP obtendo-se parte das informações dos acontecimentos. Hoje, o monitoramento das faltas é feito pelo Grupo assim como os relatos das reuniões, porém ainda de forma pouco sistematizada, mas já indicando um aumento no esclarecimento da importância de um monitoramento próprio.Em certo sentido, o fato do Grupo ter incorporado a composição de custo de seus produtos é um indicador de que, de certa maneira, o monitoramento das vendas, dos gastos, do estoque de madeira, etc estão sendo feitos pois, são subsídios para uma composição de custo justa.
Resultados relacionados à forma de ação da Incubadora

Neste sentido a construção de parcerias entre assentamentos explicita algumas destas metas e objetivos. A construção de 77 moradias no assentamento Sepé-Tiarajú na região de Ribeirão Preto, SP , distante 500 km da marcenaria, abriu a possibilidade de parceria e possibilidade viável de intercâmbio entre assentamentos do Estado onde a marcenaria entra com a produção de batentes e janelas analisando a viabilidade econômica, as estratégias de produção desde a negociação da madeira até o envio da encomenda possibilitando o acesso da população de baixa renda a uma esquadria de madeira de qualidade e eficiência.

\section{Resultados relacionados à forma de ação da} Incubadora

O atendimento as demandas do grupo por parte da INCOOP tem possibilitado uma aproximação maior entre os coletivos obtendo-se uma relação desejável de cumplicidade e companheirismo sem perder de 
máximo possível aproveitando o entusiasmo do Grupo com atividades técnicas e lúdicas. A INCOOP também tem apresentado demandas solicitando uma maior participação em reuniões com possíveis parceiros como o ITESP por exemplo.

Classe 16: Quanto ao apoio ao grupo para participação em redes de cooperação e em iniciativas do movimento de economia solidária

Características de atuação da Incubadora

A INCOOP tem oferecido informações sobre atividades da Economia Solidária, proposto a participação de membros do grupo em atividades que se mostrem viáveis e, quando necessário, oferecido subsídios para locomoção e hospedagem dos membros, quando se trata de atividades em outros locais distantes do Assentamento em que está situada. vista os papéis de cada um neste processo de incubação.

O exame da história de incubação, a partir do método de incubação proposto para a INCOOP em 2007, sugere relações relevantes entre aspectos do fazer da INCOOP, características dos segmentos sociais participantes da experiência, e resultados alcançados na organização destes indivíduos. Ratificando o exposto por Cortegoso et al. (2007) no exame de duas experiências de incubação no âmbito da INCOOP, dentre as muitas variáveis que influem no processo de incubação, algumas estão diretamente sob controle da incubadora, particularmente aquelas que se referem à sua própria capacitação para lidar com este processo; outras estão diretamente ligadas às características da população com a qual o trabalho é realizado e, se não cabe à Incubadora controlar, cabe a ela identificar, da forma o mais precisa possível, que papel ocupa neste processo e se preparar para lidar com elas, apresentem-se com os valores que se apresentarem.

\subsection{Caracterização da produção de janelas na Marcenaria de Mulheres}

Vários estudos e pesquisas foram realizados ao longo do processo de incubação da Marcenaria Coletiva de Mulheres os quais podemos destacar alguns relacionados a produção seriada de janelas:

1) Dissertação de mestrado de Albenise Laverde intitulada "Processo produtivo de esquadrias em madeira de eucalipto na marcenaria coletiva do Assentamento rural Piritura II - Itapeva-SP" de 2007 sob orientação da Prof. ${ }^{a}$ Assoc. ${ }^{a}$ Akemi Ino; 
2) Dissertação de mestrado de Thaísa Marques Leite intitulada "Análise da viabilidade técnica e econômica da produção de janelas de madeira de eucalipto em uma marcenaria coletiva autogestionária para projetos de habitação social rural" de 2009 sob orientação, também, da Prof. ${ }^{a}$ Assoc. a Akemi Ino;

3) Artigo de Leite et.al. (2011) sob o título "Análise do processo produtivo de janelas venezianas de madeira de eucalipto. Caso: marcenaria coletiva (Itapeva-SP/Brasil)" apresentado no $1^{\circ}$ Congresso Ibero-Latinoamericano da Madeira na Construção, Coimbra, Portugal e

4) Artigo de Leite; Gavino, Ino (2011) sob o título "O uso da madeira de plantios florestais para a produção de janelas com folhas mexicanas para habitação social rural. Estudo de caso: Marcenaria coletiva do Assentamento rural Pirituba II (Itapeva-SP)" apresentado no IV Encontro Latinoamericano sobre Edificações e Comunidades Sustentáveis em Vitória/ES.

Estes estudos possuem semelhanças no que diz respeito ao objeto de estudo (o processo de produção de janelas em uma marcenaria coletiva) a partir de uma perspectiva da viabilidade técnica e econômica na qual os gargalos na cadeia produtiva da madeira de plantios florestais e alternativas para sanar o déficit habitacional são os debates centrais dos estudos.

Os estudos em conjunto com as observações realizadas são bases importantes para identificar as etapas de projeto e produção das janelas sob as quais esta pesquisa irá examinar 0 processo de adequação sociotécnica realizadas na relação assessoria e marceneiras, identificando pontos de maior ou menor favorecimento aos princípios da autogestão e aferição do grau de empoderamento individual e coletivo alcançados.

Cabe salientar que os processos que viabilizaram a produção das janelas são descritos em seus detalhes técnicos nas publicações citadas, não cabendo ao tópico seguinte desta pesquisa ilustrá-los detalhadamente, mas, cabe nesta síntese identificar as etapas que evidenciam aspectos importantes para o exame das relações entre a autogestão e adequação sociotécnica.

\subsubsection{Janelas para o Assentamento Rural Pirituba II: caracterização das etapas de projeto e produção}

A produção das janelas para o Assentamento Rural Pirituba II em Itapeva iniciou em meados de 2004 e foi marcada pela decisão de mulheres assentadas em absorver esta tarefa em prol do coletivo das casas e pela capacitação nos serviços qualificados de marcenaria simultaneamente a produção. Este processo de capacitação foi acompanhado, primeiramente, por pesquisadores do HABIS que em seguida contou com a experiência de um instrutor marceneiro sem 
a formação em capacitar outras pessoas para o ofício e de uma assessora em organização coletiva e autogestão.

Segundo Laverde (2007) para a produção de 144 janelas de 1,20m×1,20m da tipologia de abrir de vidro foram organizadas as seguintes etapas do processo de projeto: 1Estabelecimento de diretrizes de projeto - condicionantes técnicas e econômicas; 2- Elaboração da primeira proposta; 3- Discussão coletiva com as famílias; 4- Definição do projeto e execução do detalhamento; 5- Fabricação dos primeiros protótipos.

Segundo a autora, as propostas apresentadas para tomada de decisão dos grupos das casas foi elaborada pela assessoria técnica cujas limitantes para definição das propostas foram: disponibilidade de recursos financeiros e técnicos com a viabilidade construtiva em larga escala, para um projeto de habitação já idealizado e definido em emprocesso de construção (LAVERDE, 2007, p.149). A resposta a estas condicionantes foram, segundo a autora, "uma tipologia de janelas que estabeleceu uma correlação entre níveis de satisfação, execução e custos associados".

Para viabilizar a construção das casas e as estratégias gerais do projeto Inovarural, buscou-se a articulação da cadeia produtiva dos componentes, desde a floresta (tentativa de parceria com órgãos do governo e reflorestadoras), pelo desdobro até a secagem e tratamento (parcerias com serrarias locais).

Com a justificativa de utilização para fins sociais da madeira plantada da Fundação Florestal (órgão vinculado à Secretaria do Maio Ambiente do Governo do Estado de São Paulo), a assessoria fez a tentativa de conseguir a madeira necessária para fabricação das janelas e portas para as casas do projeto, no entanto, a parceria não se constituiu a partir da doação da madeira pois alegaram ser um volume grande de matéria-prima que deveria passar por processo de leilão. A parceria com o Instituto se efetivou apenas por meio da indicação de fornecedores de madeira da região.

De acordo com Laverde (2007) foram adquiridos cinco lotes de madeira, totalizando por volta de $60 \mathrm{~m}^{3}$ de madeira, para finalizar a produção dos componentes destinados a janelas e portas para as casas no assentamento rural Pirituba II. O contexto, o volume e características dos lotes são importantes subsídios para compreendermos alguns fatores: 0 volume de madeira necessário para a produção das janelas (este fator nos indica a necessidade de estoque de madeira necessária para a produção dos componentes da janela) e as estratégias adotadas pela assessoria para envolvimento das famílias nas etapas de aquisição e monitoramento da qualidade. 
Laverde (2007) caracterizou os lotes da seguinte maneira:

$1^{0}$ Lote - Aquisição de 15,2 $\mathrm{m}^{3}$ de madeira de eucalipto inicialmente para produção da Casa Modelo (estratégia adotada no projeto para capacitar as famílias nas várias etapas da sua execução) posteriormente por decisão das famílias este primeiro lote foi voltado para produção das janelas; negociação dos assessores diretamente com o fornecedor/doador de toras e com a serraria; realizada parceria para doação da madeira com serraria de Taquarivaí/SP (50 km do assentamento); início da participação dos assentados no descarregamento das peças ainda úmidas no pátio da marcenaria.

$2^{0}$ Lote - Aquisição de 13,23 $\mathrm{m}^{3}$ de madeira de eucalipto; negociação dos assessores diretamente com o doador de toras e com a serraria (doação realizada por empresa local de celulose); início da participação dos assentados no corte das toras na floresta.

$3^{0}$ Lote - Aquisição de 31,12 m³ de madeira de eucalipto; negociação dos assessores para compra direta com a serraria por 365 reais / m³ início da participação dos assentados no descarregamento e entabicamento das peças no pátio da marcenaria.

$4^{0}$ Lote e $5^{0}$ Lote - Aquisição de $3,24 \mathrm{~m}^{3}$ de madeira de eucalipto para $04^{\circ}$ Lote para produção de batentes das portas; em função da má qualidade desse lote a serraria fornecedora ofereceu $1,4 \mathrm{~m}^{3}$ de madeira espécie cambará, madeira que compôs $05^{\circ}$ Lote; negociação dos assessores diretamente com a serraria; início da participação dos assentados no processamento primário das peças.

A primeira iniciativa para capacitação do grupo para as atividades básicas de marcenaria foi organizada pelos assessores do HABIS, com a parceria da ESALQ-USP em Piracicaba por meio da utilização, por cinco dias consecutivos (de 26 a 30 de janeiro de 2004), do seu Laboratório de Engenharia e Máquinas para Madeira e com a participação de quatro homens, assentados que mais tarde desistiriam de participar do empreendimento.

Para aquisição do primeiro lote de madeira para produção das janelas das casas para o Assentamento Pirituba II foi realizada parceria com uma serraria no município de Taquarivaí que ofereceu seus técnicos para capacitar os integrantes da marcenaria durante os cuidados na etapa de entabicamento das peças serradas e monitoramento do teor de unidade da madeira.

Para cumprir a estratégia do projeto Inovarural de aprendizado simultaneamente a ação foi imprescindível a contratação e a atuação de um instrutor marceneiro que em conjunto com a equipe técnica realizou a formação contínua e permanente dos membros da marcenaria durante a 
etapa de produção (este marceneiro foi remunerado com recursos de pesquisa). O início da capacitação para os trabalhos básicos das três marceneiras, pioneiras na marcenaria, ocorreu durante os meses de junho e julho de 2004 por meio da fabricação de batentes, cavaletes, mesas, armários e pequenos objetos que fazem parte da infraestrutura para a produção das janelas. Segundo Laverde (2007, p.142) as capacitações realizadas neste período foram: "recebimento, armazenamento e secagem de madeira, capacitação para a leitura de desenhos, instruções sobre a operação de cada máquina com suas regulagens e medidas de segurança, processamento da madeira, montagem de componentes e monitoramento do controle de qualidade e produtividade."

\subsubsection{Janelas para o Assentamento Sepé-Tiarajú: caracterização das etapas de projeto e produção}

Para a concepção e desenvolvimento dos projetos das janelas de madeira 0 método de projetar, considerou a interação entre famílias, marceneiras e pesquisadores-assessores do grupo HABIS, para que o produto final atendesse às necessidades e desejos das famílias do Sepé. Assim como no processo de produção, foi necessário avaliações e reavaliações do projeto do produto, adequando às condições da marcenaria, como infraestrutura e capacitação técnica das marceneiras (LEITE, 2010, p. 82).

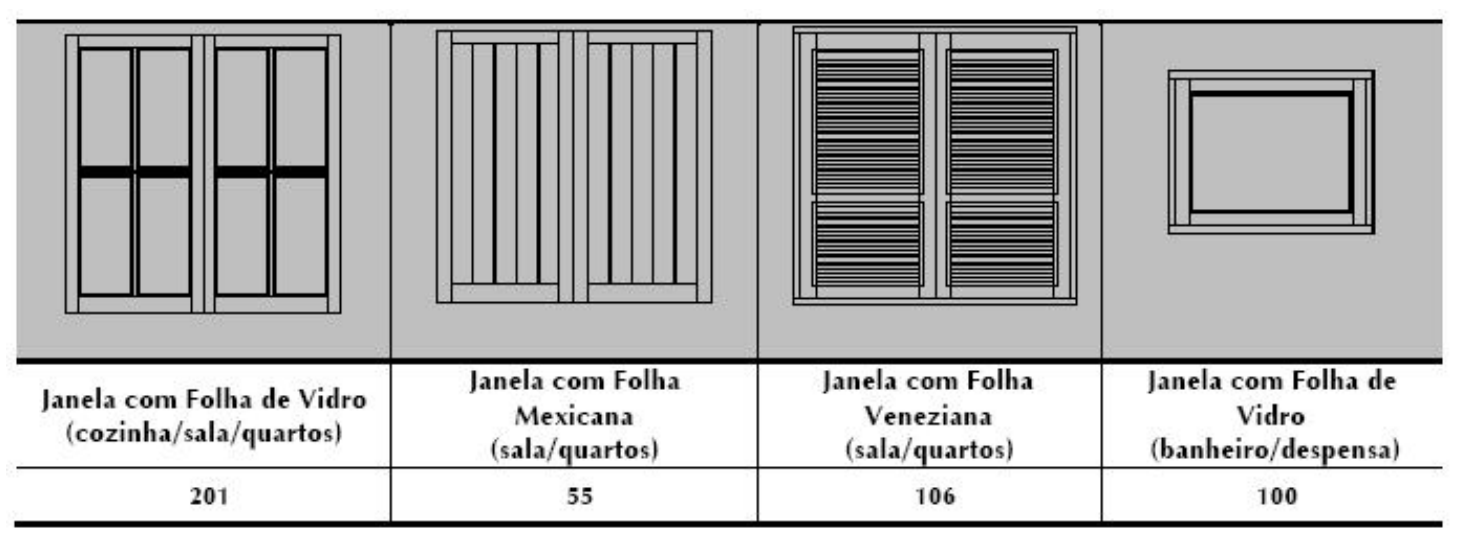

Figura 8 - Tipologias e quantidades de janelas produzidas para o assentamento rural Sepé-Tiarajú.

Fonte: LEITE, 2009.

Segundo a autora, para o Assentamento Rural Sepé-Tiarajú, a concepção e 0 desenvolvimento do projeto das janelas perpassaram pelas seguintes etapas: 1) levantamento de dados para concepção e desenvolvimento do projeto; 2) produção piloto de 10 janelas de madeira; 3) $1^{\mathrm{a}}$ discussão com as famílias das alternativas de janelas; 4) execução do $1^{0}$ protótipo da folha veneziana; 5) $2^{\mathrm{a}}$ discussão sobre as tipologias de janelas e apresentação do projeto da veneziana às famílias; 6) definição de quantitativos para cada tipologia de janelas; 7) detalhamento do desenho 
das tipologias de janelas escolhidas pelas famílias; 8) planejamento da produção. Essas etapas estão apresentadas na figura 7 no formato de um fluxograma geral do processo de projeto.

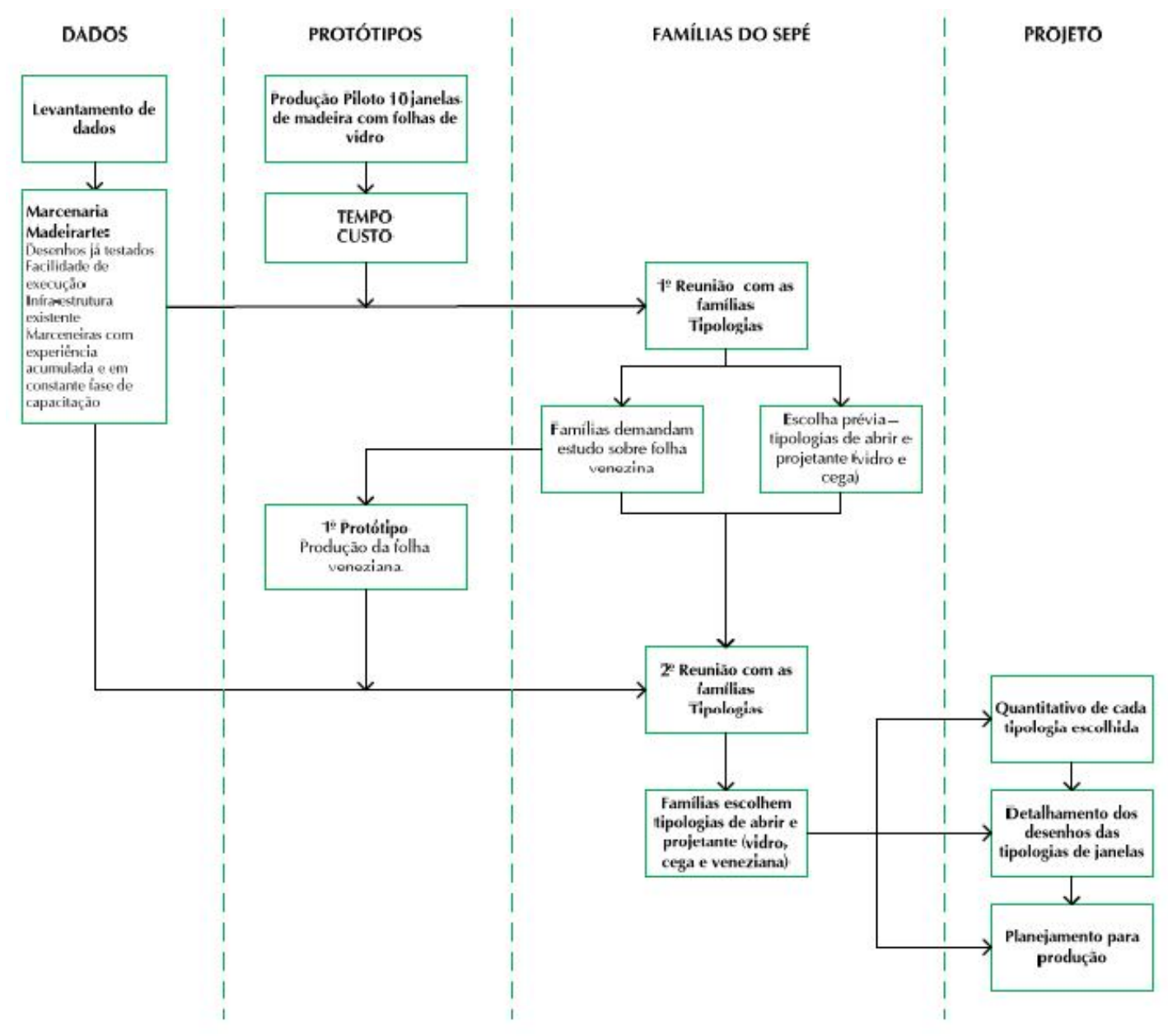

Figura 9 - Fluxograma geral do processo de projeto das janelas de madeira para o Assentamento Rural Sepé Tiarajú.

Fonte: Leite (2010, p.114).

De posse dessas informações, houve a $1^{\mathrm{a}}$ reunião com as famílias do Sepé, nessa etapa foram apresentadas duas tipologias de janela, folha de vidro e cega (mexicana), com as suas características de desempenho e custo. O resultado dessa etapa foi a demanda por estudos de produção da folha veneziana e uma escolha prévia das tipologias de janelas para cada ambiente da casa.

Com a demanda das famílias por mais uma tipologia, a folha veneziana, a marcenaria concentrou esforços para a realização do $1^{0}$ protótipo, de forma a testar desenho e processo produtivo. Além disso, foi necessário aliar os critérios estudados para as tipologias de abrir 
e projetante (vidro e cega) para a nova experiência, folha veneziana. Em seguida, retomou-se a discussão das tipologias com as famílias, apresentando o protótipo da folha veneziana. Como resultado, as famílias puderam escolher as tipologias de janelas - folhas de vidro, cega (mexicana) e veneziana - para cada ambiente da casa, gerando um quantitativo final. Além disso, pode-se desenvolver o detalhamento dos desenhos e o planejamento da produção das janelas de madeira.

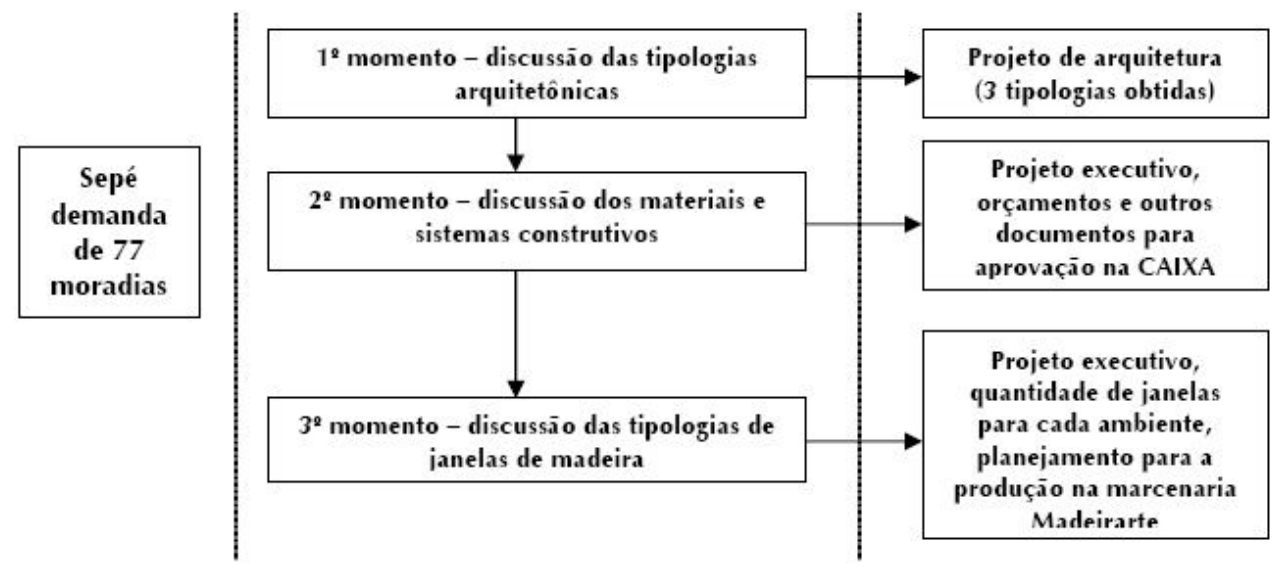

Figura 10 - Síntese do processo de discussão do projeto arquitetônico e executivo das 77 casas do Assentamento Sepé-Tiarajú.

Fonte: Leite (2010).

Já no caso das esquadrias, foi apresentada às famílias a experiência de produção de janelas de madeira pela marcenaria e um quadro comparativo (ver figura 9) entre essas janelas produzidas pela Marcenaria e janelas metálicas ( $2^{\mathrm{a}}$ linha), ambas com as mesmas dimensões. Nesse quadro comparativo estavam presentes as características e composição de cada tipo de esquadria, assim como um orçamento prévio. 


\section{Vedação}

Esquadrias de Madeira

Caracteristicas

- Janelas de abrir e máximo ar. Porta externa com batentes e folhas.

- Espécie eucalipto

- Com vidro, ferragens, tratamento e pintura.

- Janela de abrir $1.20 \times 1.20 \mathrm{~m}$ - Janela máximo ar: $60 \times 75 \mathrm{~cm}$.

- Custo janela de abrir. R\$ 130,00

- Custo janela máximo ar: R\$ 57,00

- Custo porta: R\$ 100,00 (externa c/folha)

- Custo porta interna: R\$63,00

Custo total: 2Q: RS 880,00 e $3 Q$ : R\$1035,00
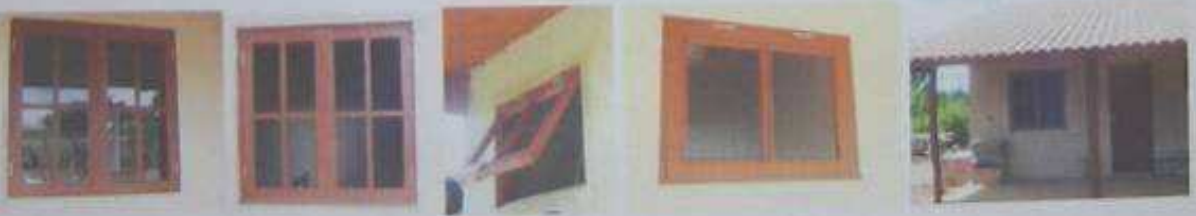

Vedação

\section{Esquadrias Metálicas}

Caracteristicas

- Janelas de correr com veneziana, de correr com vitro e máximo ar. Porta extema.

- Ferro, sem pintura

- Sem vidro mas com ferragens.

- Janela de correr com veneziana: $1.20 \times 1.20 \mathrm{~m}$ - Janela máximo ar $60 \times 80 \mathrm{~cm}$.

- Custo janela de correr. R\$ 214,00

- Custo janela de correr vitro: R\$104,00

- Custo janela máximo ar R\$ 74,00

- Custo porta externa: R\$ 200,00
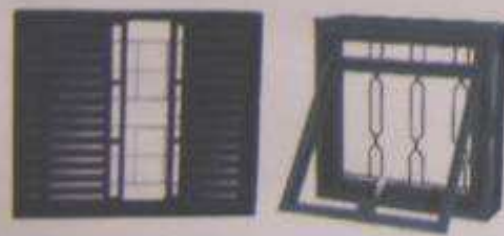

Custo total: 2Q: R\$1080.00 e 3Q:1294.00
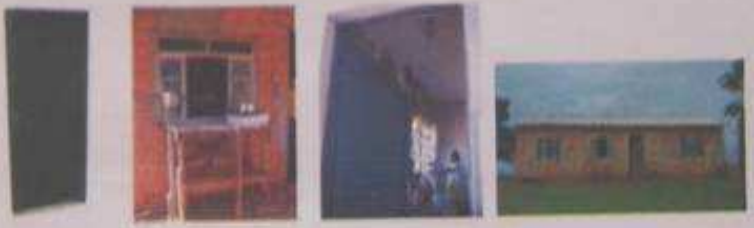

Figura 11 - Quadro comparativo entre esquadrias de madeira e metálica, apresentando suas respectivas características e custos.

Fonte: Leite (2011) 
As famílias do Sepé acataram a escolha pelo uso de madeira de plantios florestais e pela produção das esquadrias na marcenaria, como forma de incentivo ao empreendimento, gerando trabalho e renda, com a possibilidade de troca solidária entre dois assentamentos rurais. Além disso, em relação ao custo, perceberam ser mais vantajosa a janela de madeira, pois considerou no custo estimado de $\mathrm{R} \$ 130,00$, além da madeira e mão-de-obra da marcenaria, 0 vidro, as ferragens, tratamento e a pintura stain. Não foi considerado o custo de instalação das janelas, pois esse processo será realizado pelas próprias famílias no sistema de mutirão.

Segundo Leite, Gavino e Ino (2011) para a produção das 110 folhas mexicanas pela marcenaria de Itapeva foram seguidas as seguintes etapas: a) revisão do desenho da folha mexicana; b) realização de protótipo; c) produção em escala e apropriação de custo.

A Marcenaria Coletiva de Mulheres contava com um repertório e experiência em produção de janelas do tipo mexicana. Este acúmulo foi conseguido a partir de produções próprias (vendo outras janelas desta tipologia prontas) e de capacitações realizadas pelo marceneiro instrutor no início da capacitação da marcenaria em 2004. A característica do desenho da folha mexicana elaborada pelas marceneiras era a seguinte: composição de réguas, travessas inferior e superiores, com a possibilidade de uma travessa no sentido transversal às réguas ou no sentido diagonal, como um contraventamento. O encaixe entre as réguas, adotadas pela marceneiras, era por meio rebaixo. A madeira utilizada para a produção de janelas mexicanas pela marcenaria foi eucalipto urophylla. Após término das folhas e entrega da encomenda, percebeu-se que surgiram alguns defeitos como o deslocamento das réguas, criando frestas e, consequentemente, um encurvamento de todo o conjunto da folha, conforme pode ser visto na figura 2.

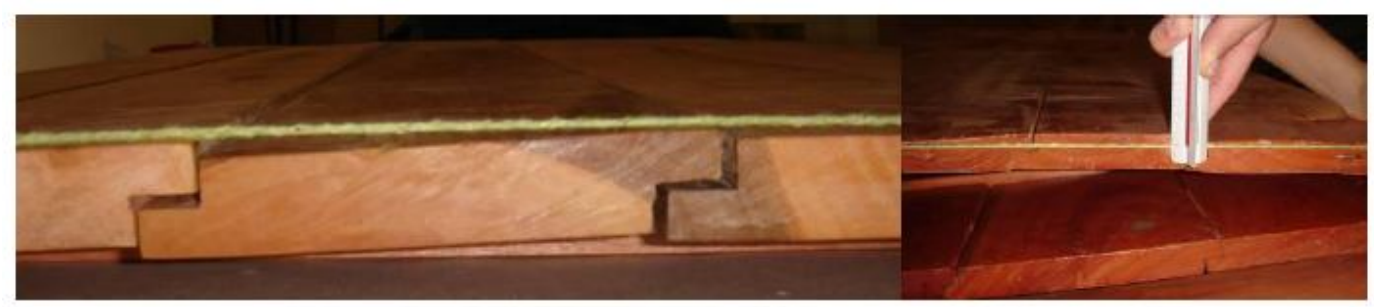

Figura 12 - Defeitos apresentados nas folhas mexicanas com encaixes de meio rebaixo, cujas folhas foram produzidas na marcenaria Marcenaria.

Fonte: acervo HABIS (2008).

Cabia as marceneiras em conjunto com a assessoria identicar as causas dos problemas. Diante dos problemas apresentados nessa encomenda de folhas mexicanas, era necessário identificar os problemas encontrados nas folhas prontas e as possíveis causas do 
surgimento de algumas patologias. Além de observar que as réguas sofreram deslocamentos, foi possível detectar, também, uso de pregos com dimensões maiores do que a espessura da folha, mau acabamento no momento de passar cola epóxi, misturado com pó de serra, na cabeça dos pregos e em alguns nós encontrados nas réguas.

Portanto, 0 desenho e o processo de produção das folhas mexicanas, o qual as marceneiras estavam acostumadas a executar, foram revistos. No desenho foi proposto às marceneiras que as réguas apresentassem encaixe macho-fêmea, o que permitiria uma área de maior contato entre as peças. Para a fixação das travessas nas réguas, seriam feitos rebaixos para colocação de parafusos ou cavilhas e para o fechamento desses rebaixos, protegendo o furo, utilizar-se-iam tarugos. (ver figura 13)
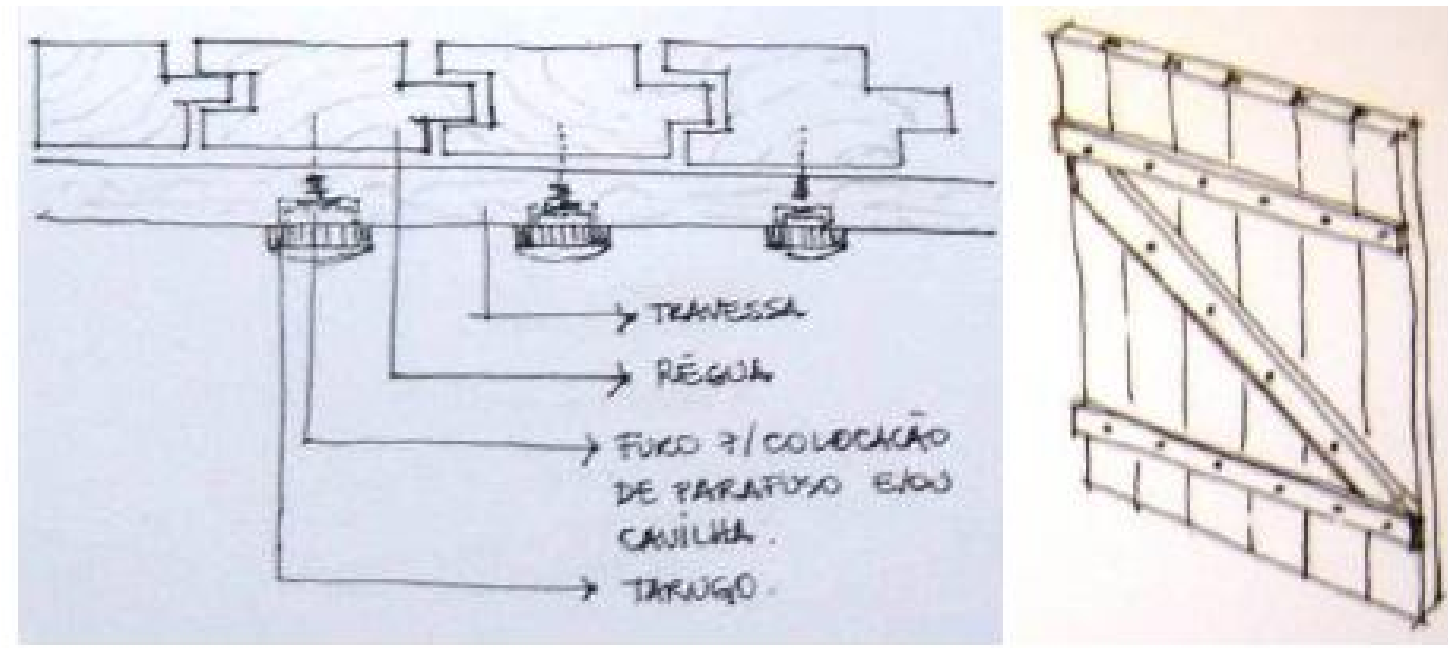

Figura 13 Croquis com corte e perspectiva da nova proposta do desenho da folha mexicana para a encomenda do Sepé.

Fonte: LEITE (2009).

Assim, seguindo o projeto das moradias do Sepé, as janelas com folhas mexicanas seriam compostas por um batente de $1.18 \times 1.15 \mathrm{~m}$, pois o vão livre era de $1.20 \times 1.20 \mathrm{~m}$ e duas folhas compostas por réguas, travessas superior, inferior e diagonal. 

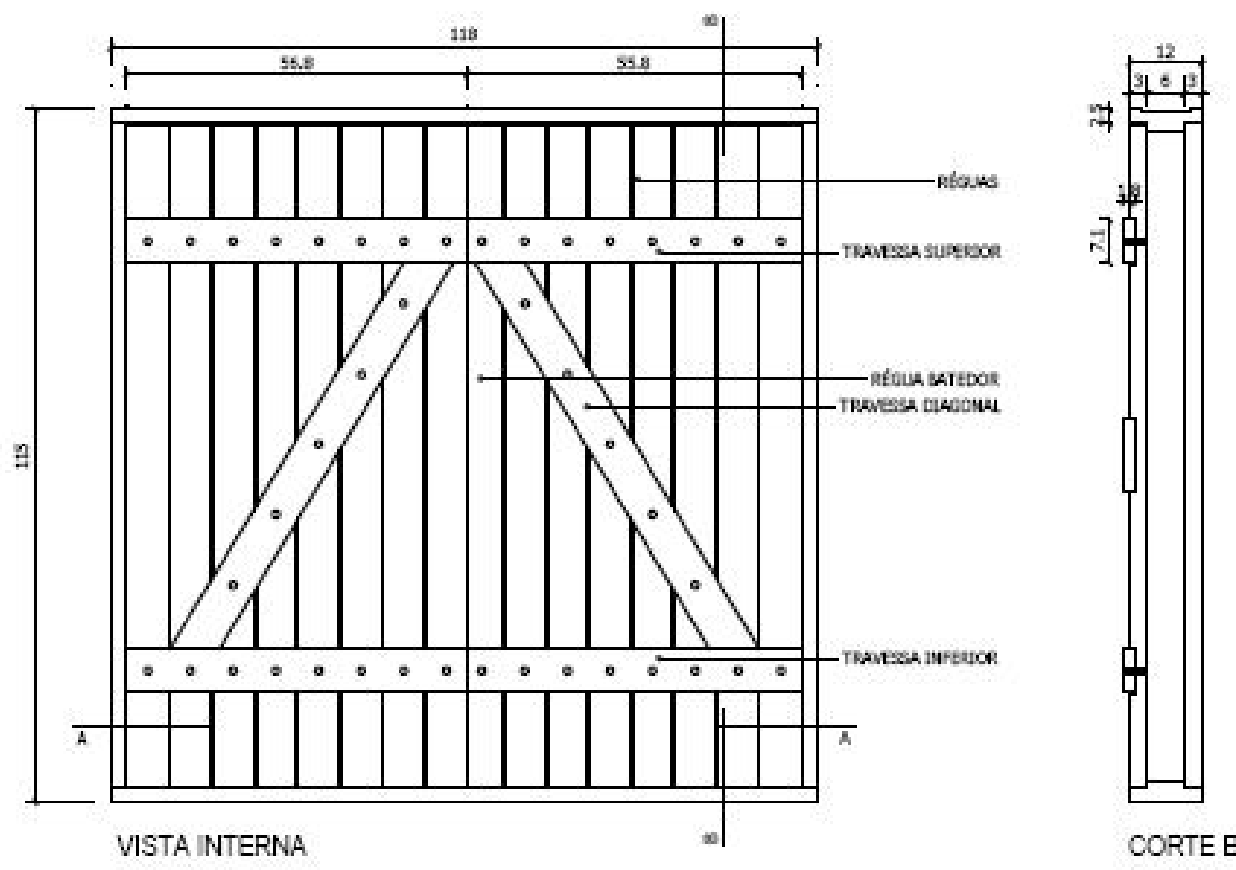

CORTE BB

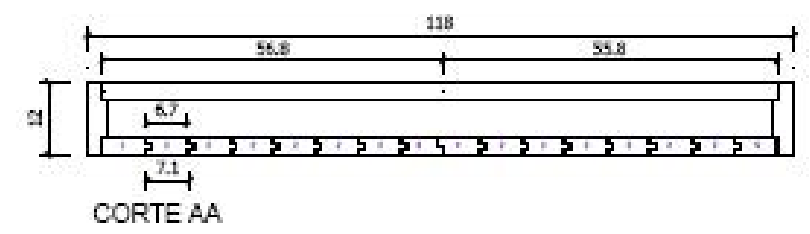

Figura 14 - Desenho técnico da janela com folha mexicana (batente e folhas), com 1.18×1.15m. Fonte: LEITE (2009).

Como forma de testar o novo desenho da folha mexicana, era necessária a realização de um protótipo. Com o recebimento do lote de madeira de eucalipto grandis, proveniente da região de Telêmaco Borba-PR, foi realizado no mês de julho de 2008, o protótipo da folha mexicana, com a presença de 03 marceneiras, 01 jovem aprendiz e 02 pesquisadores-assessores do grupo HABIS/INCOOP (IAU-USP e UFSCar).

Para a realização do protótipo foi feita uma capacitação com as marceneiras com explicações do novo desenho e foi retirada, inicialmente, uma proposta de romaneio das peças para a produção, em escala, de 110 folhas mexicanas. O lote de madeira adquirido estava dividido em peças de $1^{\mathrm{a}}, 2^{\mathrm{a}}$ e $3^{\mathrm{a}}$ qualidade, mas o número de peças de primeira qualidade era insuficiente para a produção de todas as peças componentes das 110 folhas mexicanas. Portanto, propuseram-se duas alternativas, cuja primeira seria voltada para produção de 30 janelas, ou seja, 60 folhas com peças brutas de $1^{\mathrm{a}}$ qualidade. E para segunda alternativa, seriam utilizadas peças brutas de $1^{\mathrm{a}}$ e $2^{\mathrm{a}}$ qualidade para a produção de 25 janelas, ou seja, 50 folhas. Nesse caso, as peças brutas de $1^{\text {a }}$ qualidade seriam empregadas na produção de componentes que recebem os maiores esforços 
como as travessas inferior, superior e a diagonal de contraventamento. E as de $2^{\mathrm{a}}$ qualidade, seriam empregadas para a produção das réguas.

Com a modificação do desenho da folha mexicana foi necessário rever o processo produtivo. Portanto, para a realização desse protótipo, as etapas de produção das folhas foram: processamento primário ( $1^{\circ}$ destopo, desempeno, desengrosso, $2^{0}$ destopo); processamento secundário (produção de réguas, travessas inferior e superior e travessas de contraventamento); montagem da folha mexicana (pré-montagem, furação, colocação de parafusos ou cavilhas, colocação de tarugos e lixamento); acabamento final da folha; e armazenagem. Nas figuras 15, 16, e 17 é possível observar a sequencia de produção do protótipo da folha mexicana.
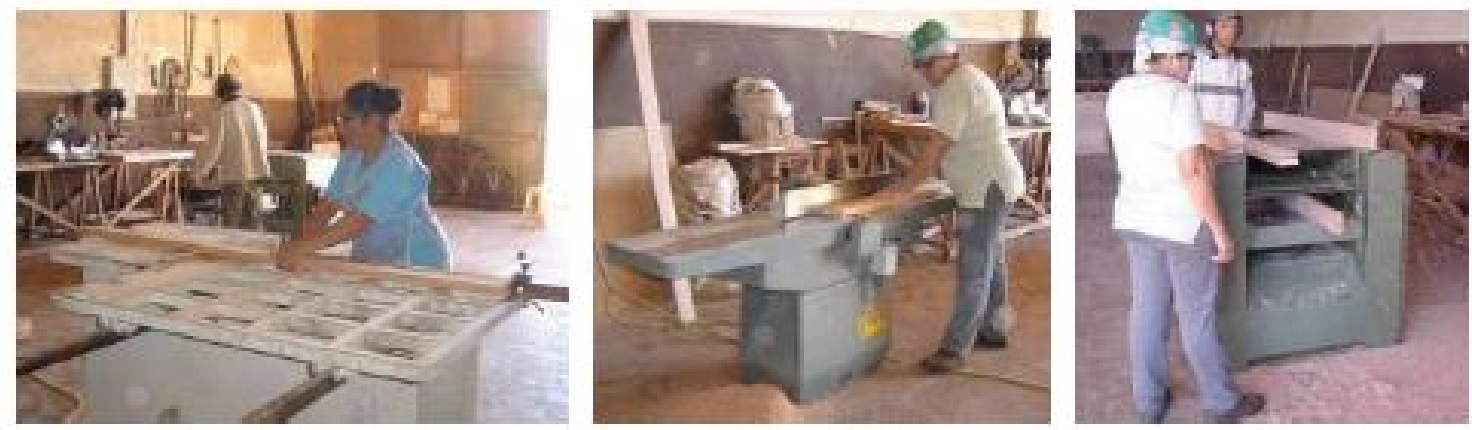

Figura 15 - Imagens referentes às etapas do processamento primário - destopo, desempeno e desengrosso. Fonte: acervo HABIS (2008).
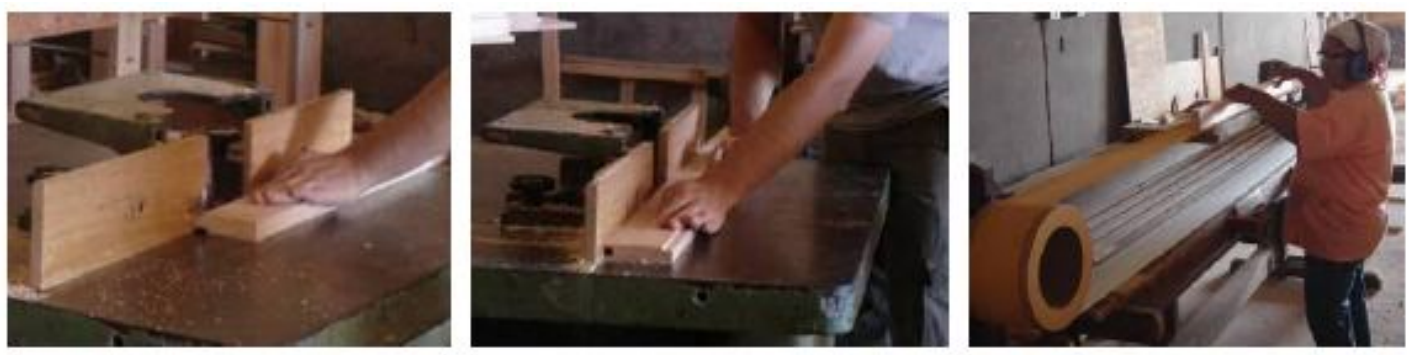

Figura 16 - Imagens referentes às etapas do processamento secundário - execução dos encaixes machofêmea na tupia e lixamento das peças.

Fonte: acervo HABIS (2008).

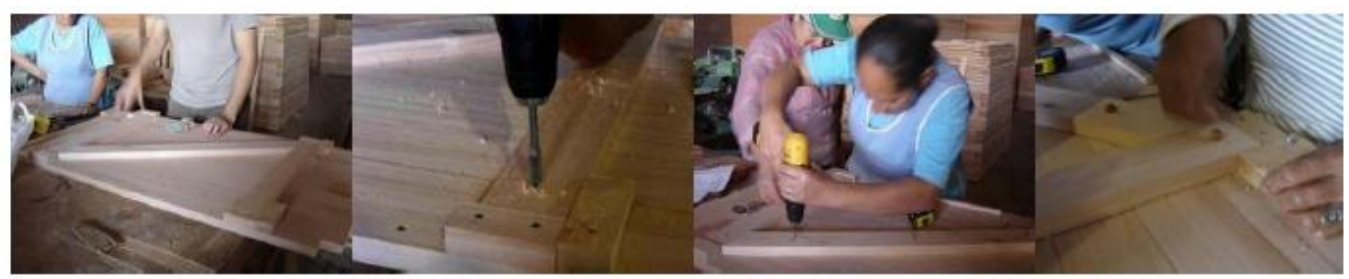

Figura 17 - Imagens referentes às etapas da montagem da folha mexicana - pré-montagem, furação, colocação de parafusos e de tarugos.

Fonte: acervo HABIS (2008). 
Uma das etapas importantes no processo de produção das folhas mexicanas é a execução dos encaixes do tipo macho-fêmea. Na realização do protótipo, os pesquisadoresassessores do grupo HABIS e INCOOP colocaram a importância de se observar, na seção das peças, o sentido dos anéis de crescimento da madeira. As marceneiras foram capacitadas de sempre intercalar o sentido desses anéis, ora para cima, ora para baixo, pois quando a peça de madeira sofrer retrações ou inchamento, uma peça compensará a outra, diminuindo as possibilidades de se formar frestas entre os encaixes das réguas. (ver figura 18)
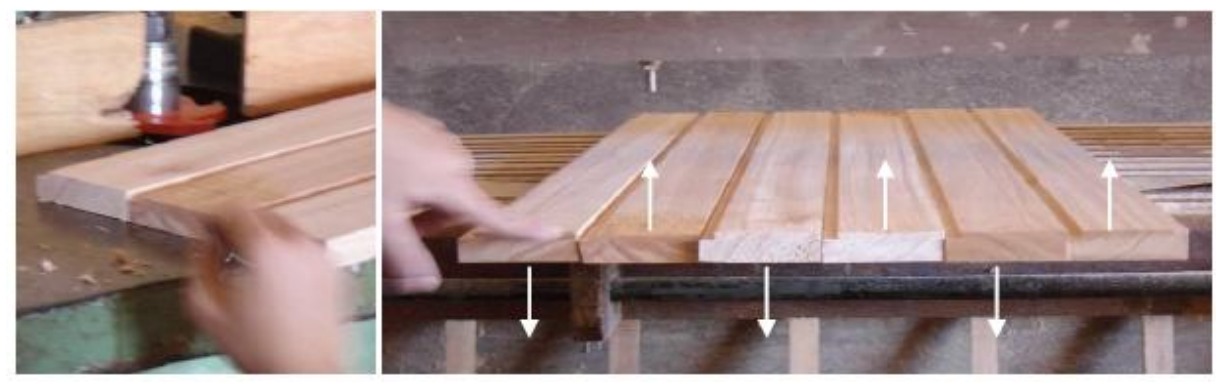

Figura 18 - Demonstração de como devem ficar posicionadas as réguas, em relação aos anéis de crescimento das peças de madeira.

Fonte: acervo HABIS (2008).

Nessa etapa de preparação das peças e execução dos encaixes macho-fêmea, fazse importante 0 trabalho em grupo, onde uma das marceneiras fosse responsável por fazer marcas que indiquem, no momento de execução dos encaixes, qual o sentido dos anéis de crescimento, e a outra, responsável pela execução dos encaixes macho-fêmea. Assim, com a marcação, facilitaria no momento da execução dos encaixes na tupia e no posicionamento das réguas no momento da montagem na mesa gabarito.

Apesar das explicações, as marceneiras se sentiram inseguras em realizar essa observação das peças, na execução dos encaixes. Percebendo essa dificuldade, os pesquisadoresassessores partiram para prática, onde as marceneiras puderam, então, entender como observar 0 sentido dos anéis, decidiram os tipos de marcas indicativas para anéis de crescimento com sentido para baixo e outro para cima e realizar os encaixes, executando todos os encaixes do tipo macho e, depois, ajustando a tupia, para realizar todos os encaixes do tipo fêmea.

Durante a realização do protótipo, montou-se uma mesa gabarito, como é possível observar na figura 19, de forma a facilitar o encaixe correto das réguas, fixando a largura final da folha. E, também, o posicionamento das travessas inferior e superior nas réguas das folhas, facilitando as etapas de furação e aparafusamento. 

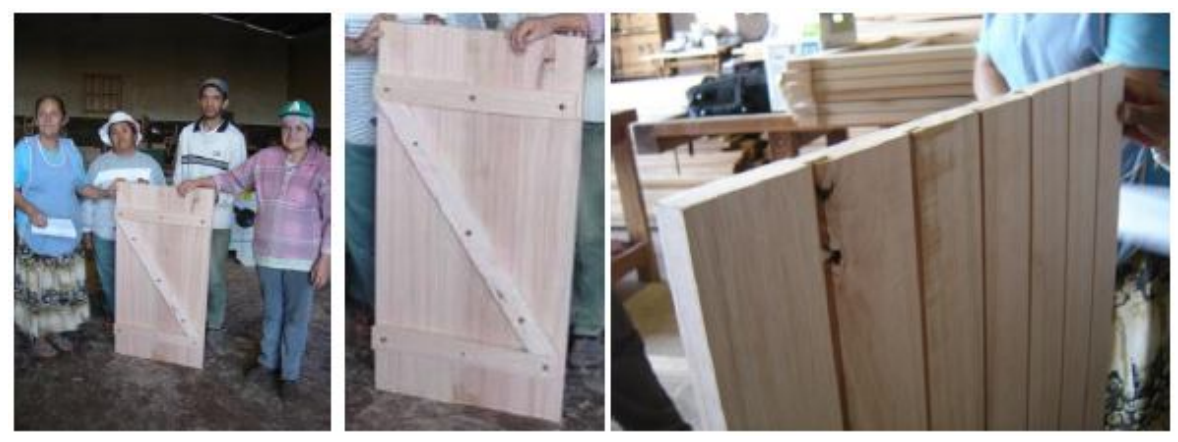

Figura 19 - Protótipo da folha mexicana com o uso da madeira de eucalipto grandis - $1^{\mathrm{a}}$ e $2^{\mathrm{a}}$ qualidade. Fonte: acervo HABIS (2008).

O resultado da experiência de produção do protótipo da folha mexicana foi satisfatório. O lote de madeira adquirido de eucalipto grandis, em Telêmaco Borba-PR, havia passado pelo processo de secagem em estufa e suas peças foram pré-selecionadas, o que acarretou em peças com menos incidência de defeitos como nós e rachaduras de topo. Isso proporcionou em diminuição de perdas.

Além disso, a capacitação das marceneiras e dos jovens aprendizes em relação a todo processo produtivo, inclusive na fase de intercalar as réguas em virtude dos anéis de crescimento, foram pontos importantes para garantir tanto qualidade durante o processo produtivo $\mathrm{e}$ no produto final.

Em relação à produtividade, percebeu-se que para a produção em escala, estimouse que levariam 10 dias para a produção de 110 folhas, considerando 4 pessoas. Mas, de acordo com as anotações do caderno de apontamento diário da marcenaria, foram necessários 16 dias para a produção de 110 folhas mexicanas, considerando a média de 04 pessoas. Esse prolongamento de 6 dias em relação ao estimado é devido ao fato de que na etapas inicial, 0 processamento primário foi realizado apenas por duas marceneiras. E para a etapa de montagem, apesar da presença de 04 pessoas, só havia uma única mesa com gabarito, ou seja, tinha-se um único ponto de montagem da folha mexicana.

Para a apropriação de custos, considerando que a madeira adquirida de eucalipto grandis teve um custo de $\mathrm{R} \$ 700,00 / \mathrm{m}^{3}$ (matéria-prima, secagem em estufa e transporte até a marcenaria) e o valor do serviço técnico da marcenaria foi de $R \$ 3,30 / h$, chegou-se no valor de $R \$$ 130,25 (batente + folha mexicana) por janela, sem considerar impostos embutidos em notas fiscais. Fez-se uma estimativa com valores dos impostos, o que passaria para $\mathrm{R} \$ 175,91$. Na figura 20 é possível observar os valores que mais impactaram na estimativa de custo da folha mexicana. Entre 
eles estão em ordem de maior participação: madeira, tratamento com pintura stain, mão-de-obra e 0 fundo de reserva da marcenaria.

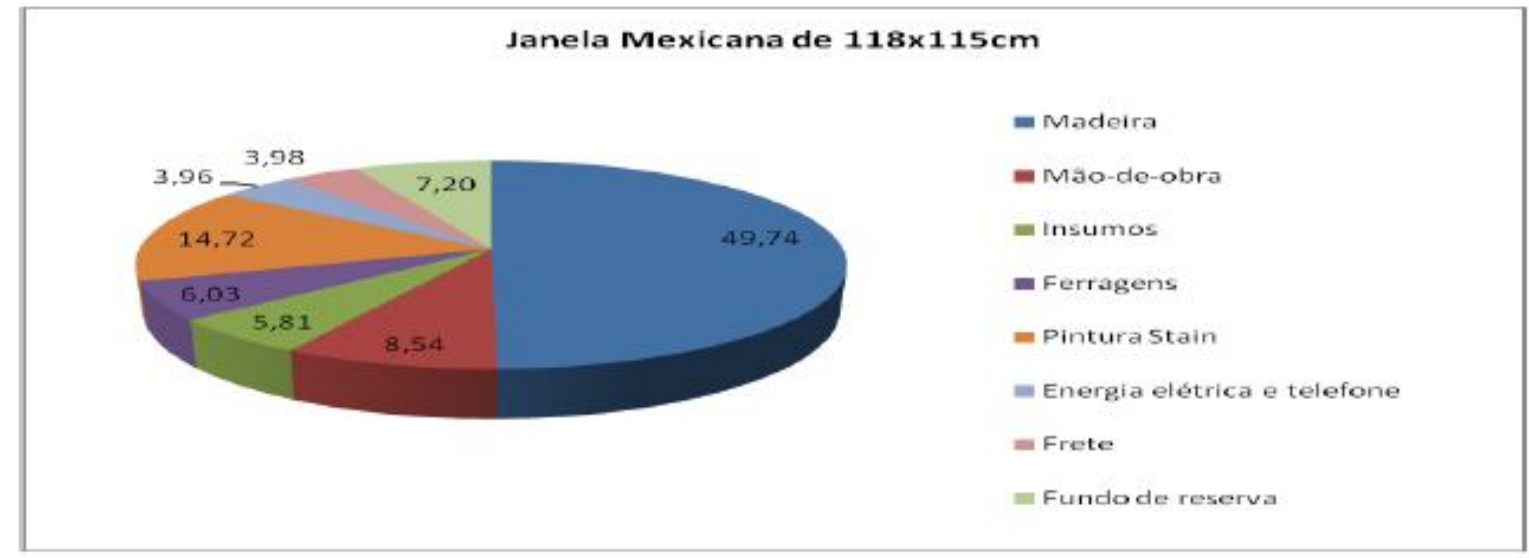

Figura 20 - Participação (valores em porcentagem) de cada item na formação do custo estimado da janela com folhas mexicanas.

Fonte: LEITE (2009).

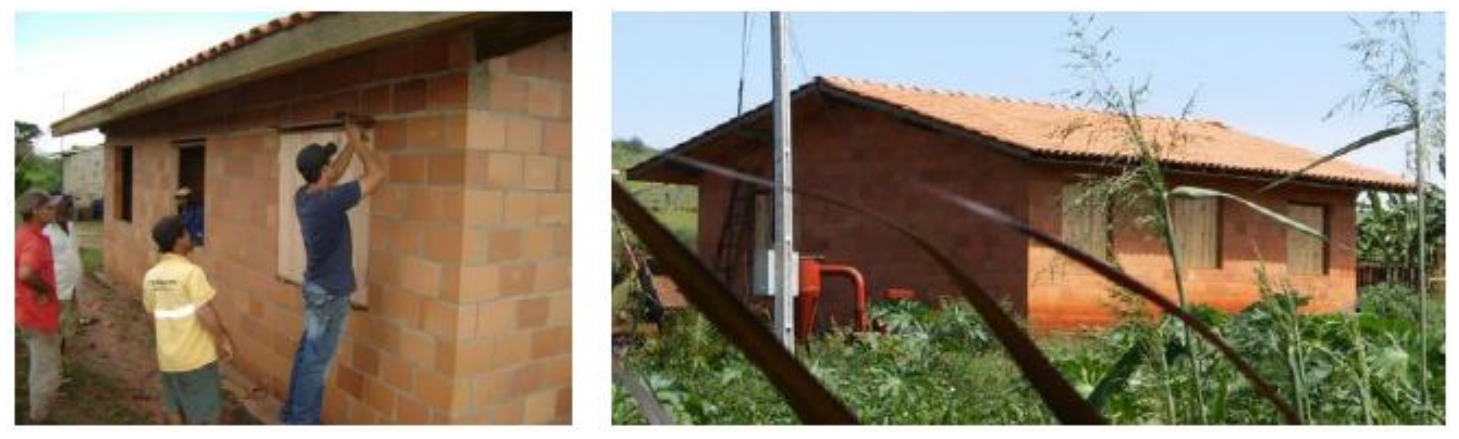

Figura 21 - Instalação das janelas com folhas mexicanas nas moradias do Assentamento Rural Sepé Tiarajú (Serra Azul-SP).

Fonte: acervo HABIS (2009).

Após reuniões com as famílias do assentamento, juntamente com os pesquisadores do grupo HABIS e, também, as marceneiras da marcenaria coletiva de Itapeva, definiu-se quais as tipologias de janelas a serem produzidas, que entre elas estavam as janelas com folhas de vidro e folhas mexicanas. Nessa mesma reunião, pode-se firmar a parceria entre os dois assentamentos e, surgiu uma proposta das famílias do assentamento Sepé-Tiarajú, em viabilizar a produção de uma terceira tipologia que seria a janela com folhas venezianas.

Assim, pesquisadores e marceneiras uniram esforços para viabilizar a produção de janelas venezianas, estudando desenhos e realizando protótipos. As etapas desse processo são: a) visita técnica a uma marcenaria próxima a região do assentamento Pirituba II; b) proposta de desenho e realização de protótipo; c) identificação dos gargalos encontrados; d) produção em escala das folhas venezianas. 
De acordo com Leite et al (2011), para a produção do protótipo da folha veneziana, as marceneiras, jovens aprendizes e os pesquisadores assessores do grupo HABIS contaram com a parceria de uma marcenaria experiente, localizada na cidade de Itararé-SP. Nessa marcenaria foi possível conhecer o método de produção de uma folha veneziana, utilizando maquinários como uma destopadeira de eixo horizontal, que apresenta um custo menor de aquisição, se comparada a uma furadeira de veneziana.

Na visita técnica, foi possível entender a etapa de execução de cortes na máquina destopadeira de eixo horizontal, cujos cortes serviriam de encaixe das palhetas das venezianas. $E$, também, foi possível acompanhar a etapa de execução dos cortes inclinados a $45^{\circ}$ das palhetas, com 0 auxílio de um gabarito. Na figura 22, tem-se alguns dos registros realizados durante essa visita.

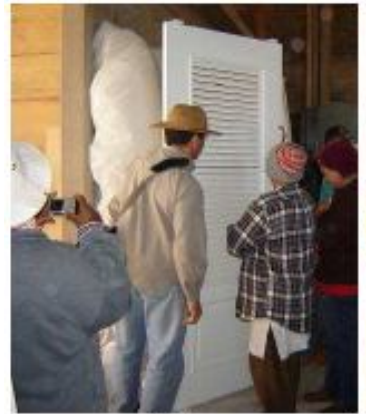

(a)

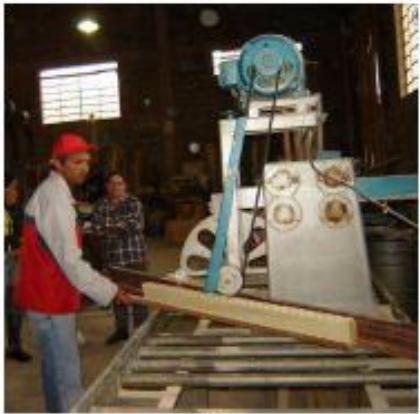

(b)

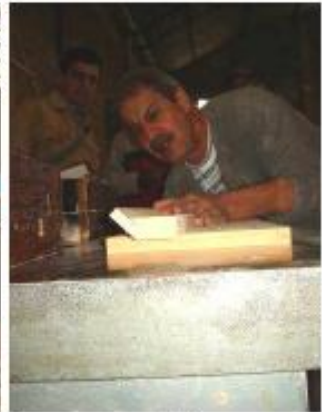

(c)

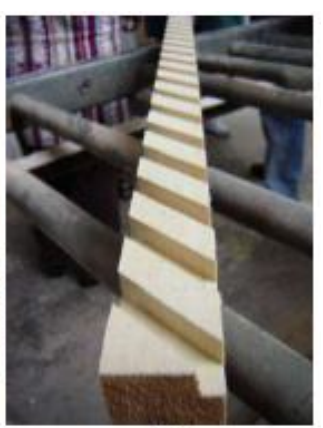

(d)

Figura 22 - Visita técnica à marcenaria de Itararé-SP. (a) Exemplo de uma porta com venezianas, (b) capacitação para execução dos cortes nos montantes de borda, com o uso da máquina destopadeira de eixo horizontal, (c) capacitação para execução das palhetas inclinadas a $45^{\circ} \mathrm{e}(\mathrm{d})$ exemplo de um montante de borda com os cortes que servirão para o encaixe das palhetas.

Fonte: acervo HABIS, 2007.

Como resultado dessa visita técnica, foi possível desenvolver o desenho da folha veneziana, do tipo portuguesa, onde há um trespasse da palheta no montante, ou seja, a palheta não é embutida no montante, mas sim encaixada. Na figura 23 , tem-se a proposta desenvolvida para a produção do protótipo da folha veneziana, composta por 2 montantes de borda, 2 travessas de borda, 1 travessa interna, palhetas e o gabarito para garantir os distanciamentos na execução dos cortes.

Segundo especificações do projeto das moradias do Sepé, o vão destinado às janelas era de $1.20 \mathrm{~m} \times 1.20$ e as medidas externas das janelas, considerando os batentes, foram de $1.18 \mathrm{~m} \times 1.15 \mathrm{~m}$. 


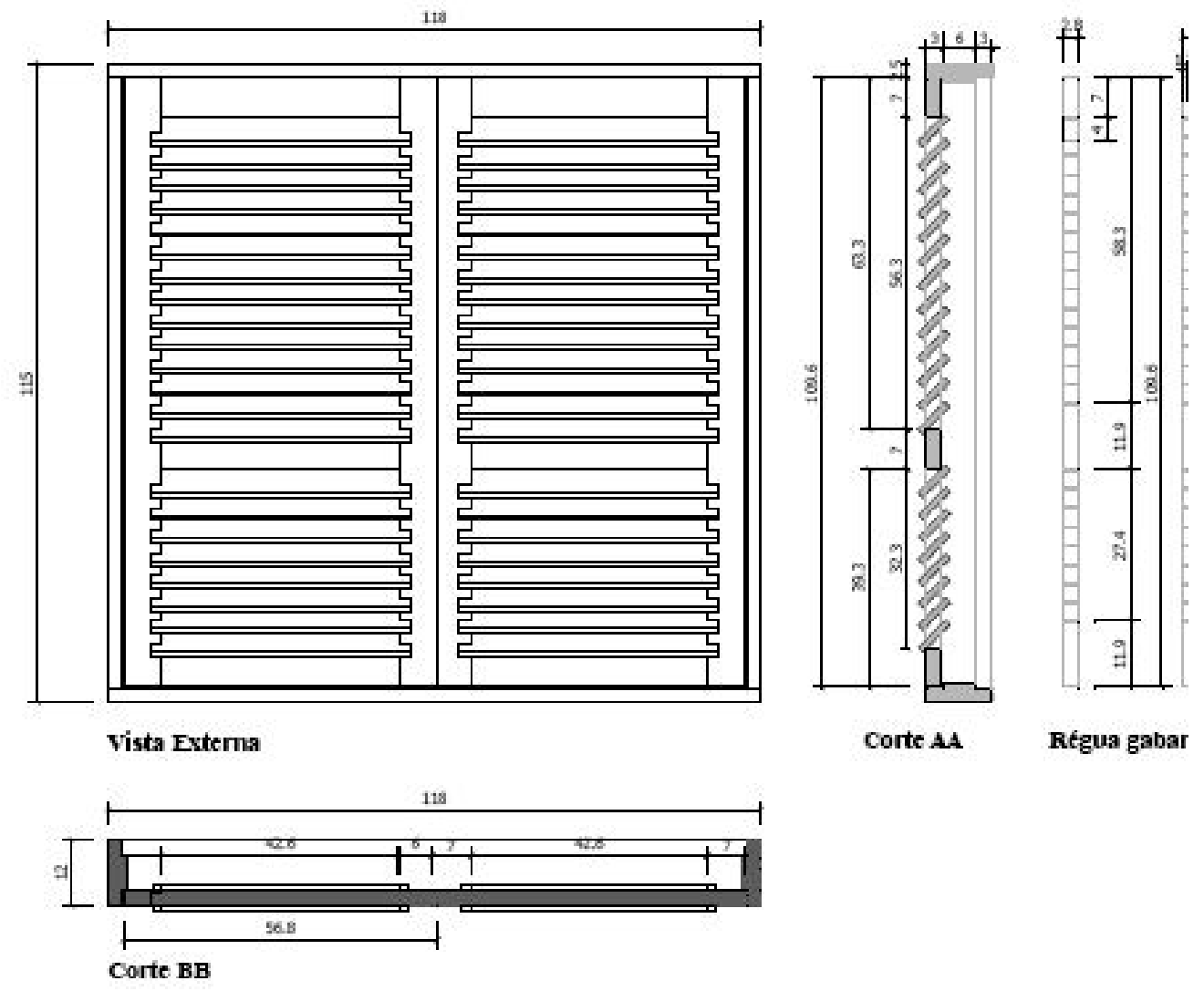

Figura 23 - Desenho da folha veneziana para a realização do protótipo. Fonte: acervo HABIS, 2007

A produção do protótipo foi realizada em um dia e dividiu-se nas etapas de preparação para produção, com a explicação do processo produtivo e de realização da produção. No primeiro momento da produção do protótipo da folha veneziana, levantaram-se as seguintes etapas para o processo produtivo: processamento primário, processamento secundário (montantes, travessas e palhetas), montagem, processamento final e armazenagem da folha.

Para o protótipo foram utilizadas tábuas de $3 \times 9 \times 260 \mathrm{~cm}$, de eucalipto grandis (palhetas) e eucalipto urophylla (montantes e travessas).

No segundo momento da realização do protótipo, dividiu-se em dois turnos. Como os montantes de borda já estavam processados, fez-se a execução dos cortes para o encaixe das palhetas, na marcenaria de Itararé-SP, visto que a marcenaria coletiva não dispunha da máquina destopadeira de eixo horizontal. E o processamento das travessas e palhetas fez-se na marcenaria coletiva pelo período da manhã. No período da tarde, fez-se a execução dos encaixes nas palhetas, com 0 auxílio de formão e montagem da folha veneziana. A figura 24, apresenta o protótipo da folha veneziana finalizado. 

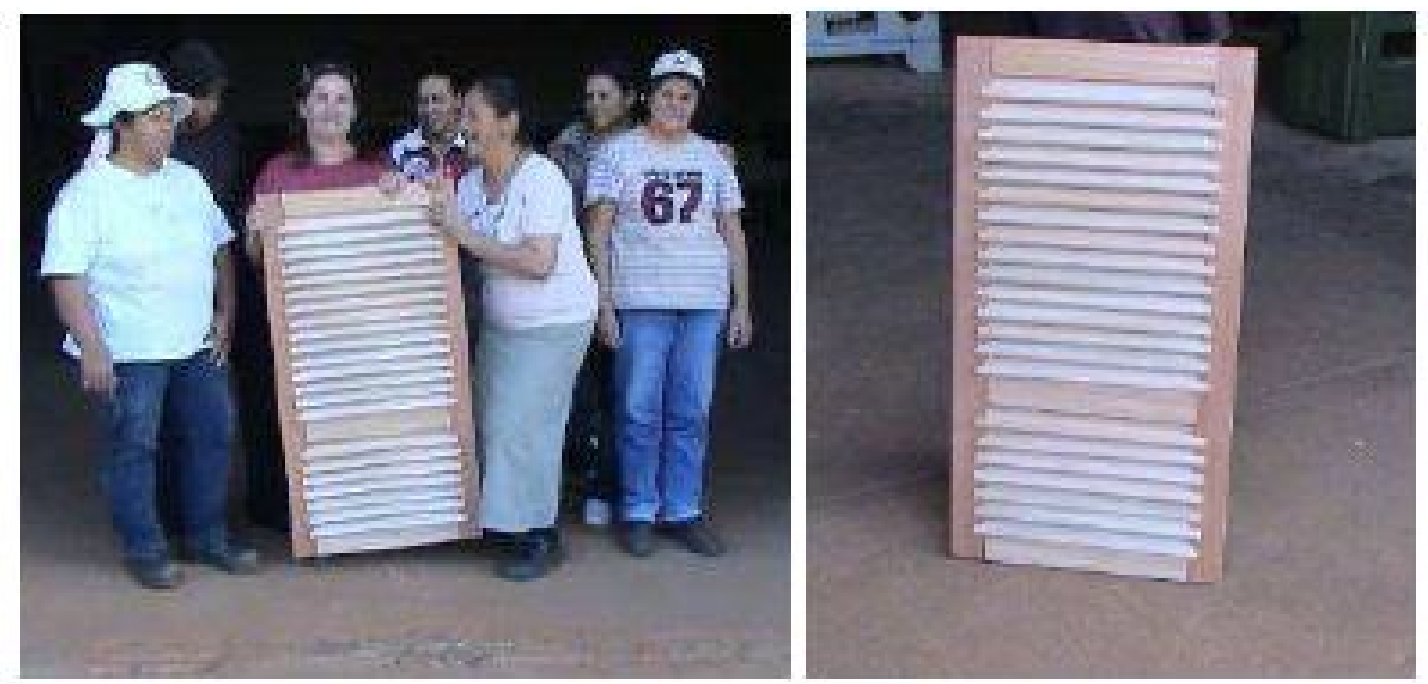

Figura 24 - Protótipo da folha veneziana finalizado.

Fonte: acervo HABIS, 2007.

Para a produção em escala das folhas venezianas, não houve alteração do desenho proposto no momento da realização da produção do protótipo. Portanto, considerando 0 mesmo desenho, tem se que seriam necessários $7,65 \mathrm{~m}^{3}$ de eucalipto grandis, para a produção de 212 folhas venezianas. Em etapa anterior, os batentes das folhas já haviam sido produzidos com 0 uso da madeira de eucalipto saligna.

As etapas para a produção de folhas venezianas são: processamento primário (destopo, desempeno e desengrosso); processamento secundário - execução de montantes de borda, travessa de borda, travessa interna e palhetas (execução dos furos nos montantes e das espigas nas travessas, grosagem de espigas, execução dos cortes nos montantes e nas palhetas, lixamento das peças); montagem da folha veneziana (pré-montagem, colocação das palhetas e montagem final); processamento da folha veneziana (destopo da folha e execução do batedor); e armazenamento da folha.

$\mathrm{Na}$ produção do protótipo da folha veneziana, a etapa referente aos cortes nas palhetas para o encaixe nos montantes, foi realizada com o uso do formão. Para reduzir o tempo gasto com o uso do formão, foi desenvolvido um gabarito para efetuar esses cortes na tupia, com a utilização de uma serra oscilante, a fim de aperfeiçoar a etapa de cortes das palhetas (ver figura 25). 


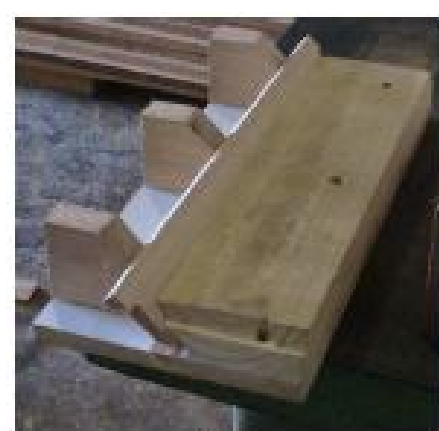

(a)

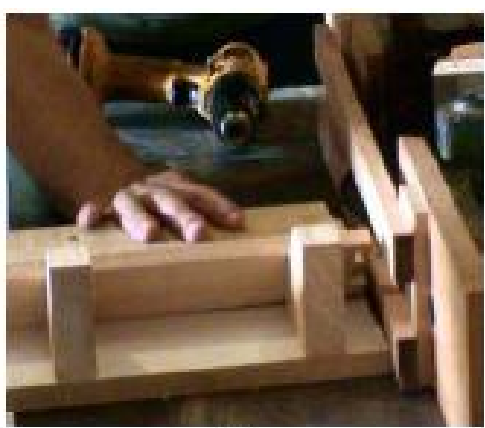

(b)

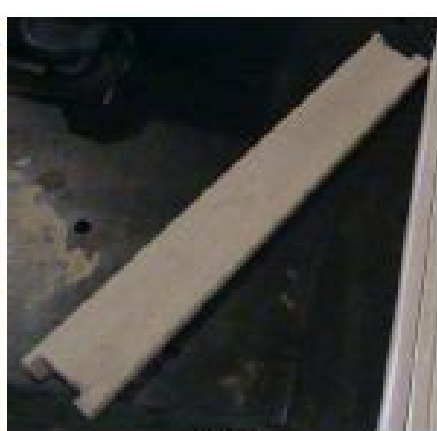

(c)

Figura 25 - Realização dos cortes das palhetas para a produção das 212 folhas venezianas. (a) gabarito com inclinação de $45^{\circ}$, (b) Realização dos cortes das pa Ihetas na tupia, com a serra oscilante e (c) palheta pronta.

Fonte: acervo HABIS, 2007.

Outro teste realizado foi relativo ao uso da destopadeira de eixo horizontal para a execução dos cortes nos montantes de borda, cujos cortes permitem o encaixe das palhetas. No momento da produção do protótipo, os cortes nos montantes de borda foram realizados na marcenaria de Itararé-SP. Com a orientação e capacitação, para a execução dos cortes dos montantes, dada pelos marceneiros chefes (marcenaria de Itararé-SP), a equipe de pesquisadoresassessores do grupo HABIS buscou seguir as mesmas especificações de máquina, rotação do motor e fresa utilizadas por essa marcenaria, para a compra da destopadeira de eixo horizontal, a fim de viabilizar a produção das folhas venezianas na Marcenaria Coletiva de Mulheres.

Com a compra da máquina, a partir de recursos próprios da marcenaria, iniciaramse os testes em montantes de eucalipto grandis ${ }^{18}$, no mês de dezembro de 2007, a fim de verificar os espaçamentos entre os cortes, assim como, fazer com que os integrantes da marcenaria se habituassem à utilização da máquina destopadeira. Como resultado do teste, percebeu-se que 0 montante em eucalipto grandis apresentava uma alta facilidade de lasquear, como mostra a figura 26, letra c.

18 O lote de madeira adquirido para a fase inicial da produção era proveniente da região de São Miguel Arcanjo-SP. Esse lote passou pelo processo de secagem em estufa e não se optou pelo uso de tratamento químico. Apesar de ter passado pelo processo de secagem em estufa, no momento da entrega na marcenaria, a umidade se encontrava incompatível para o inicio dos trabalhos, necessitando finalizar o processo de secagem pelo método natural. Além disso, não houve uma seleção adequada das peças após o processo de secagem. Portanto, o lote apresentava peças com rachas no topo e no sentido longitudinal. 


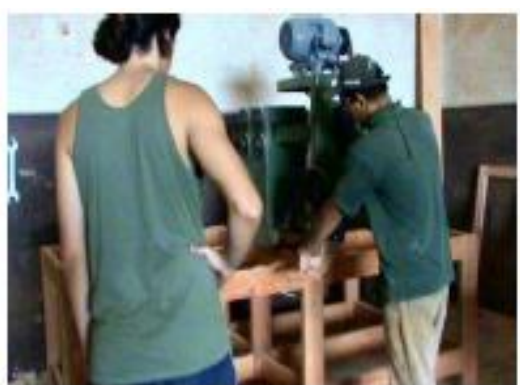

(a)

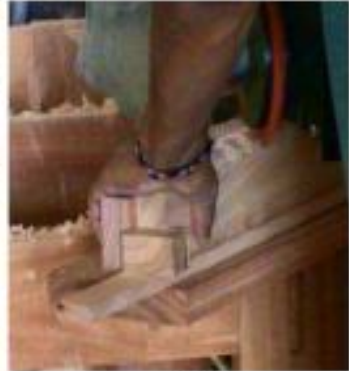

(b)

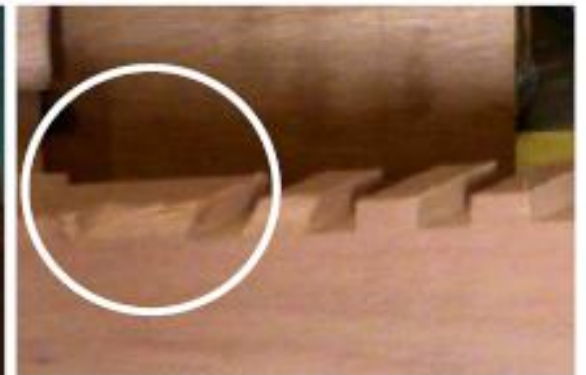

(c)

Figura 26 - Realização de testes na execução dos cortes ou fresas no montante de borda, na destopadeira, para as folhas venezianas. (a), (b) execução dos cortes dos montantes na destopadeira e (c) detalhe do montante de borda, com defeitos na finalização dos cortes.

Fonte: acervo HABIS, 2007.

Diante de tal situação, o desafio da equipe de pesquisadores-assessores do grupo HABIS e da marcenaria era buscar soluções para adequar o tipo de madeira, eucalipto grandis, à máquina destopadeira e ao tipo de fresa para realização dos cortes nos montantes. Além da busca por profissionais experientes na capacitação para realização das folhas venezianas, com o uso da máquina destopadeira, como foi o caso do apoio da marcenaria de Itararé-SP, buscou-se também orientações de pesquisadores especializados na área de processamento da madeira (Unesp/ltapeva-SP) e, também, de marceneiro instrutor que pudesse viabilizar a produção e a capacitação das marceneiras, na ausência dos pesquisadores-assessores do grupo HABIS.

Em discussão com os pesquisadores especialistas da Unesp de Itapeva-SP, chegou-se a algumas alternativas que poderiam ser utilizadas, na substituição da máquina destopadeira de eixo horizontal, que está presente na Tabela 13.

Tabela 13 Alternativas para execução dos cortes para o encaixe das palhetas nos montantes.

\begin{tabular}{|c|c|c|c|c|c|}
\hline $\begin{array}{l}\text { Equipamento, } \\
\text { máquina e } \\
\text { ferramenta }\end{array}$ & $\begin{array}{c}\text { Serra } \\
\text { esquadrejadeira } \\
\text { de mesa/fresa }\end{array}$ & $\begin{array}{l}\text { Fresa com } \\
\text { riscador }\end{array}$ & Serra oscilante & $\begin{array}{l}\text { Serra tico-tico } \\
\text { manual e fresa }\end{array}$ & $\begin{array}{l}\text { Máquina Furadeira } \\
\text { para veneziana }\end{array}$ \\
\hline Operação & $\begin{array}{c}\text { Passar a peça } \\
\text { primeiramente na } \\
\text { serra } \\
\text { esquadrejadeira de } \\
\text { mesa, nos limites } \\
\text { dos rasgos e } \\
\text { depois retirar o } \\
\text { miolo na fresa } \\
\text { (destopadeira) }\end{array}$ & $\begin{array}{c}\text { Fazer os rasgos } \\
\text { das peças } \\
\text { utilizando fresa } \\
\text { c/riscador } \\
\text { (destopadeira) }\end{array}$ & $\begin{array}{l}\text { Fazer os rasgos } \\
\text { com o uso da serra } \\
\text { oscilante (anexar à } \\
\text { destopadeira) }\end{array}$ & $\begin{array}{c}\text { Fazer os rasgos } \\
\text { iniciais (os limites } \\
\text { dos rasgos) com a } \\
\text { serra manual e } \\
\text { depois retirar o } \\
\text { miolo na fresa } \\
\text { (destopadeira) }\end{array}$ & $\begin{array}{c}\text { Execução } \\
\text { automática dos } \\
\text { rasgos, em dois } \\
\text { montantes de } \\
\text { borda, } \\
\text { simultaneamente }\end{array}$ \\
\hline Vantagem & $\begin{array}{c}\text { Máquina e } \\
\text { equipamento } \\
\text { existentes na } \\
\text { marcenaria }\end{array}$ & $\begin{array}{l}\text { Execução mais } \\
\text { rápida e menor } \\
\text { possibilidade de } \\
\text { lasquear a peça }\end{array}$ & $\begin{array}{l}\text { Execução mais } \\
\text { rápida }\end{array}$ & $\begin{array}{c}\text { Máquina e } \\
\text { equipamento } \\
\text { existentes na } \\
\text { marcenaria }\end{array}$ & $\begin{array}{c}\text { Execução mais } \\
\text { rápida e precisa } \\
\text { dos rasgos para } \\
\text { encaixe das } \\
\text { palhetas }\end{array}$ \\
\hline Desvantagem & $\begin{array}{l}\text { Maior tempo de } \\
\text { execução }\end{array}$ & $\begin{array}{l}\text { Custo da fresa com } \\
\text { riscador }\end{array}$ & $\begin{array}{l}\text { Custo da serra } \\
\text { oscilante }\end{array}$ & $\begin{array}{l}\text { Maior tempo de } \\
\text { execução }\end{array}$ & $\begin{array}{l}\text { Custo da máquina } \\
\text { furadeira para } \\
\text { veneziana }\end{array}$ \\
\hline
\end{tabular}

Fonte: Leite, 2009. 
As soluções como a substituição da fresa de corte reto pela fresa com ranhura ou serra oscilante, seria inviável para marcenaria em função do custo dos equipamentos. Segundo pesquisas em lojas de equipamentos específicos para marcenaria, no estado de São Paulo, o custo de um conjunto de fresa com ranhura era de, aproximadamente, $\mathrm{R} \$ 800,00$. Outra opção que garantiria maior rapidez e qualidade na produção das folhas seria adquirir uma máquina furadeira para veneziana. $O$ custo de uma máquina nova era de $\mathrm{R} \$ 10.000,00$ e de máquina usada era de, aproximadamente, $\mathrm{R} \$$ $4.800,00$. Esses valores são referentes à pesquisa de preço realizada no período de abril de 2008 , em lojas especializadas em máquinas e equipamentos, novos e usados, para marcenarias, tanto no estado de São Paulo quanto no estado do Paraná.

Só seria viável a compra de uma máquina furadeira para veneziana para a marcenaria Marcenaria, se houvesse encomendas constantes de folhas venezianas, de forma a compensar o custo do equipamento. Como a marcenaria não tem essa proposta de especialização na produção de componentes para folhas venezianas em madeira e, também, naquele momento, não dispunha de sobras no fundo de reserva para aquisição de novos equipamentos e máquinas, não foi possível adotar essas propostas para a produção de folhas venezianas, para o Sepé.

Diante da inúmeras interrupções na produção das folhas venezianas, na marcenaria coletiva devido aos problemas encontrados, principalmente, com o uso da máquina destopadeira e diante de alternativas inviáveis para produção das janelas venezianas, as marceneiras, em conjunto com marceneiro da região, adaptaram a serra esquadrejadeira de mesa para a realização dos cortes dos montantes de borda, para o encaixe das palhetas (ver figura 27 e 28).

Este fato indica um grau de adequação sociotécnica elevado jáq que a solução partiu de agentes locais em conjunto e a pedido das próprias marceneiras. Apesar de ser uma opção que envolve maior tempo de execução, foi a solução encontrada perante ao contexto da marcenaria, que envolve a indisponibilidade financeira para adotar outras soluções citadas na Tabela 7; marceneiras que estão em constante fase de capacitação, o que seria mais viável utilizar maquinários que essas mulheres já estivessem habituadas; e o prazo de entrega dessas folhas no assentamento Sepé-Tiarajú. 


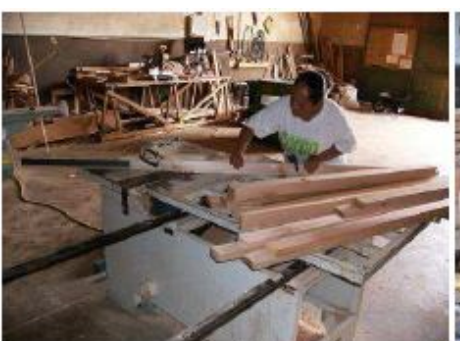

(a)

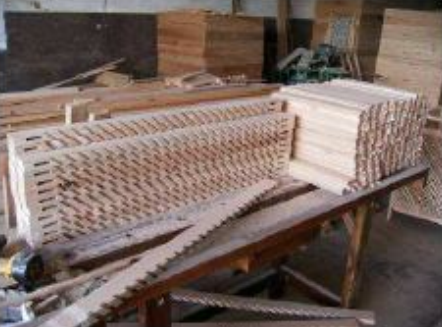

(b)

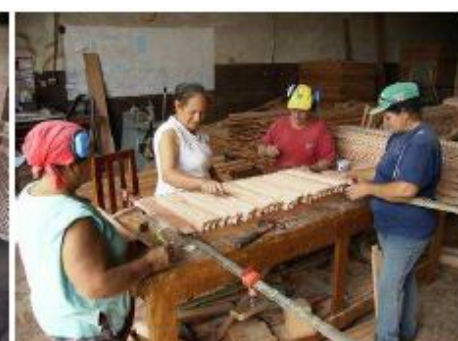

(c)

Figura 27 - Solução adotada para a produção em escala da folha veneziana. (a) execução dos cortes nos montantes, na serra esquadrejadeira, com o auxilio de um gabarito à 45; (b) montantes já com os cortes inclinados; (c) montagem das palhetas nos montantes.

Fonte: acervo HABIS, 2009.

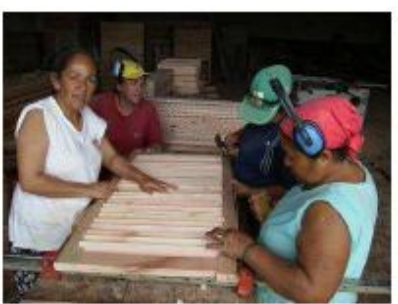

(a)

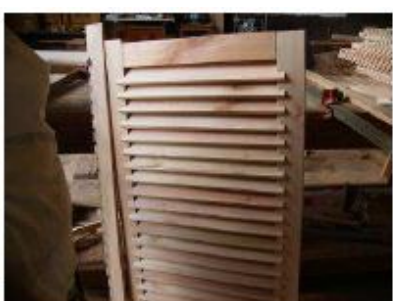

(b)

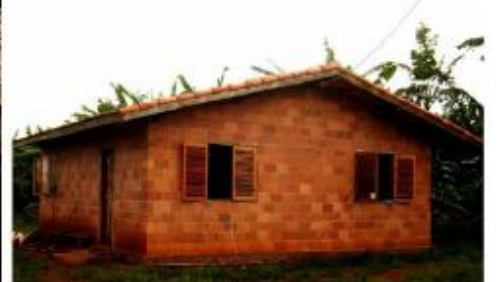

(c)

Figura 28 - Solução adotada para a produção em escala da folha veneziana. (a) montagem da folha veneziana; (b) montagem da folha veneziana finalizada; (c) exemplo de uma casa do Sepé com a folha veneziana instalada.

Fonte: acervo HABIS, 2009. 


\section{EXAME DA PRODUÇÃO DE JANELAS: RELAÇÕES ENTRE AUTOGESTÃO E ADEQUAÇÃO SOCIOTÉCNICA}

A descrição do contexto em que surgiu a marcenaria, a caracterização do grupo que compõe o empreendimento, a descrição do processo de incubação e a descrição do processo de produção das janelas na Marcenaria Coletiva de Mulheres possibilitou a exploração holística e sistêmica dos acontecimentos. Esta exploração acontece na perspectiva de aumentar nossa compreensão sobre as variáveis que interferem nas relações entre a autogestão e adequação sociotécnica no âmbito de um empreendimento conduzido majoritariamente por mulheres agricultoras e avós na cadeia produtiva de componentes de madeira para habitação. Neste processo, soma-se a revisão da literatura sobre os temas abordados que auxiliaram, igualmente, na identificação das variáveis a serem examinadas. Desta forma, neste capítulo serão apresentados os exames relacionados as seguintes categorias de análise para posterior verificação das hipóteses: 0 exame da transição para autogestão e o Exame dos processos de adequação sociotécnica na Marcenaria Coletiva de Mulheres.

\subsection{Exame da transição para autogestão da Marcenaria Coletiva de Mulheres}

A escolha de uma certa abordagem teórica do conceito de autogestão e o exame do caso - Marcenaria Coletiva Autogestionária - revela que, em escala e graus diversos, existem muitos elementos sociais, de organização e de produção os quais encontram-se presentes no empreendimento. Uma análise possível destes elementos sociais indica perspectivas e possíveis tendências de evolução do grau de autogestão do empreendimento. 


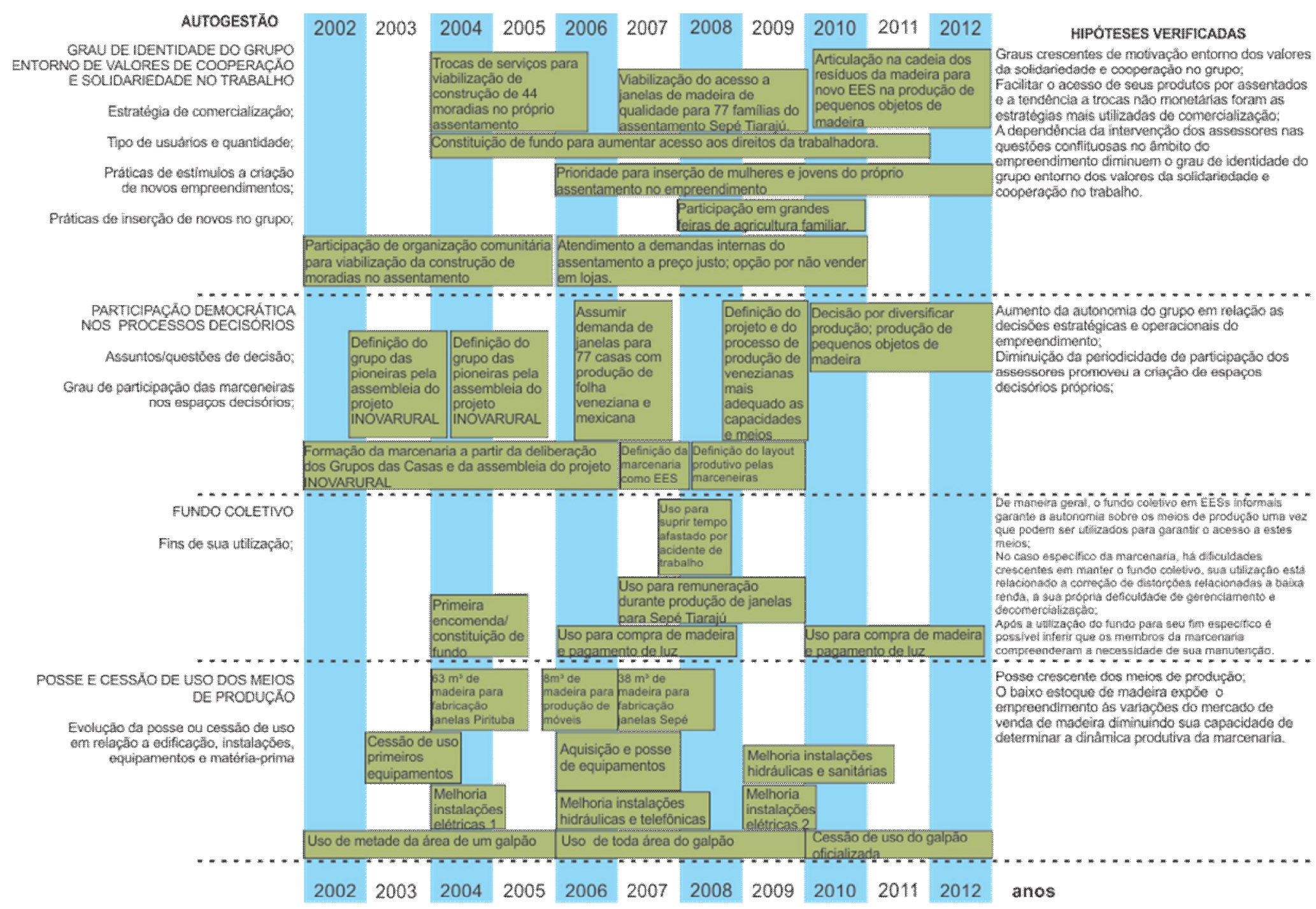

Figura 29 - Linha do tempo contendo a síntese do exame do processo de transição para autogestão da Marcenaria Coletiva de Mulheres contendo as variáveis identificadas e as hipóteses verificadas. 


\subsubsection{Aumento da posse e controle dos meios de produção pelo empreendimento}

Abaixo serão analisadas as posses ou cessões de uso pelo empreendimento dos seguintes meios de produção: 1) Edificação; 2) Equipamentos e ferramentas; 3) Instalações; 4) Matéria prima (madeira).

\subsubsection{Posse ou cessão de uso do edifício}

Para a instalação da marcenaria, houve duas alternativas para o espaço físico: um barracão aberto, somente com cobertura e sem instalação elétrica, com aproximadamente $80 \mathrm{~m}^{2}$, localizado na Agrovila 1 ou um barracão fechado, com instalação elétrica para iluminação, com área aproximada de $200 \mathrm{~m}^{2}$, distante $4 \mathrm{~km}$ da Agrovila (local de moradia das marceneiras).

A segunda edificação, localizada na Agrovila 4, era utilizada para o armazenamento de sementes e de excedente de produção das famílias moradoras dali. Em acordo com os mesmos e o ITESP - Instituto de Terra do Estado de São Paulo "José Gomes da Silva" - decidiu-se que a marcenaria dividiria 0 espaço com as famílias, ou seja, 50 \% do edifício para 0 estoque de grãos das famílias e 50\% para a produção de componentes em madeira da marcenaria.

Diante da ampliação das atividades da marcenaria apareceu a necessidade de um espaço maior para armazenamento da madeira serrada e dos componentes fabricados.

Em reunião com o ITESP, o grupo da marcenaria e famílias da Agrovila 4, decidiram que a edificação poderia ser utilizada integralmente pela marcenaria, através de uma cessão de uso formalizada. Em contrapartida, a marcenaria ajudaria na luta pela reforma de outros barracões para as famílias da Agrovila 4.

Com esta descrição pode-se notar a importância de se obter uma edificação para abrigar a produção da marcenaria. Nota-se também, que desde 0 início do empreendimento 0 envolvimento dos cooperados e das famílias, os maiores interessados, foi intensamente buscado. Esta abordagem teve como finalidade a inserção dos membros da marcenaria em negociações com parceiros e contato com a prática da autogestão. 


\subsubsection{Posse ou cessão equipamentos existentes na marcenaria}

Em 2003 o HABIS foi contemplado com R\$ 12.000,00 do Prêmio Mostra PUC-Rio com o projeto: "Habitação em assentamento rural como oportunidade de capacitação profissional e geração de trabalho e renda", cujos recursos orçamentários seriam destinados exclusivamente à aquisição de equipamentos para uma marcenaria. Assim o grupo HABIS decidiu que os recursos obtidos do prêmio seriam destinados para aquisição de equipamentos para o Grupo da Marcenaria no Assentamento Pirituba II. $O$ acordo entre o grupo HABIS e o grupo da Marcenaria definiu que os equipamentos seriam como cessão de uso temporário até o momento que o grupo da Marcenaria pudesse constituir um fundo coletivo para aquisição própria dos equipamentos.

Com este recurso foi possível adquirir os equipamentos mínimos necessários para uma marcenaria, de segunda mão e reformados: plaina desempenadeira; plaina desengrossadeira; furadeira horizontal de mesa; serra esquadrejadeira. Para aquisição de outros equipamentos foram utilizados os recursos obtidos pelo grupo HABIS no Programa Habitare FINEP (chamada pública 2003), no valor de $R \$ 2.500,00$ que permitiu a compra de lixadeira de mesa e tupia adquirida de uma marcenaria desativada da região.

Tabela 14 Levantamento de equipamentos adquiridos e identificação da posse da propriedade.

\begin{tabular}{l|c|c|c|c|c} 
Descrição & Finalidade & valor (R\$) & origem recursos & Posse do bem & Data \\
\hline Plaina desengrossadeira & aplainar & 2.800 & Prêmio Mostra 2003 PUC - Rio & HABIS19 & mar/03 \\
Plaina desempenadeira & aplainar & 5.000 & Prêmio Mostra 2003 PUC - Rio & HABIS & mar/03 \\
Furadeira de mesa & furar & 1.000 & Prêmio Mostra 2003 PUC - Rio & HABIS & mar/03 \\
serra esquadrejadeira & esquadrejar & 3.200 & Prêmio Mostra 2003 PUC - Rio & HABIS & mar/03 \\
lixadeira de fita & lixar & 1.500 & $\begin{array}{c}\text { Programa Habitare / FINEP } \\
\text { chamada pública 2003 }\end{array}$ & USP20 & mar/03 \\
tupia & fresar & 1.000 & $\begin{array}{c}\text { Programa Habitare / FINEP } \\
\text { chamada pública 2003 }\end{array}$ & USP & mar/03 \\
esmerilhadeira & esmerilhar & 200 & $\begin{array}{c}\text { Programa Habitare / FINEP } \\
\text { chamada pública 2003 }\end{array}$ & USP
\end{tabular}

${ }_{19}$ Esses equipamentos pertencem provisoriamente ao grupo da Marcenaria por meio de uma cessão verbal de uso concedida pelo grupo Habis, indicando um esforço do grupo Habis em buscar fontes de financiamento para a viabilidade de um empreendimento coletivo.

${ }^{20}$ Esses equipamentos pertencem provisoriamente ao grupo da Marcenaria por meio de uma cessão de uso concedida pelo contrato de concessão do convênio FINEP. Sendo a posse concedida ao proponente do projeto no caso a USP e a UFSCar. 


\begin{tabular}{l|c|c|c|c|c} 
furadeira de bancada & furar & 400 & Prêmio UNISOL / Banco Real & Marcenaria & set/06 \\
topejadeira & serrar & 500 & Prêmio UNISOL / Banco Real & Marcenaria & set/06 \\
\hline compressor & pintar / limpar & 600 & Prêmio UNISOL / Banco Real & Marcenaria & set/06 \\
respigadeira & respigar & 4.200 & Prêmio UNISOL / Banco Real & Marcenaria & fev/07 \\
\hline lixadeira de cinta manual & lixar & 800 & Convênio RTS / FINEP & UFSCar21 & mai/07 \\
bancada de marceneiro & apoio & 500 & Convênio RTS / FINEP & UFSCar & mai/07 \\
\hline serra de fita & serrar & 2.500 & Prêmio UNISOL / Banco Real & Marcenaria & mai/07 \\
\hline
\end{tabular}

Fonte: Arquivo HABIS/IAU/USP, 2008

A análise da situação atual dos equipamentos adquiridos pela marcenaria aponta para um crescimento do número de equipamentos em posse do empreendimento que somam um valor total de 8.200 reais em bens em posse da marcenaria coletiva, ou seja, $30 \%$ do total de 24.200 reais em equipamentos do empreendimento. Contudo, o cenário é frágil, pois equipamentos essenciais para a marcenaria estão sob a posse das instituições proponentes dos projetos que demandam recursos ao empreendimento.

A perspectiva é que, os equipamentos que pertencem provisoriamente ao grupo da marcenaria, sejam adquiridos através de um fundo coletivo do empreendimento, ou seja, o acordo coletivo é se fazer provisões para se adquirir estes equipamentos. Estas provisões viriam de uma porcentagem sobre 0 valor final do produto produzido na marcenaria, acordado em 10\%. Outra possibilidade a ser estudada é analisar a possibilidade de doação dos equipamentos sob cessão de uso do empreendimento.

\subsubsection{Posse ou cessão das instalações existentes na marcenaria}

Por meio da análise do quadro 10 se verifica 0 aumento da capacidade do empreendimento de transformar para melhor 0 ambiente de trabalho através de recursos privados não reembolsáveis. Apenas as instalações elétricas estão sob cessão de uso, no entanto, equivalem a $46 \%$ do valor final investido em instalações. 
Tabela 15 Levantamento das instalações executadas e identificação da posse da propriedade.

\begin{tabular}{l|c|c|c|c|c|} 
Descrição & Itens & valor (R\$) & origem recursos & Posse do bem & Data \\
\hline elétrica & $\begin{array}{c}\text { comp. } \\
\text { Elétricos }\end{array}$ & 1.500 & $\begin{array}{c}\text { PSH - Programa de } \\
\text { Subsídio a Habitação } \\
\text { CEF - INCRA }\end{array}$ & HABIS* & fev/04 \\
hidráulica & $\begin{array}{c}\text { aparelhos } \\
\text { sanitários } \\
\text { receptor via } \\
\text { telefônica }\end{array}$ & 2.000 & Prêmio UNISOL / Banco Real & Marcenaria & abr/06 \\
telefônico. & 100 & Prêmio UNISOL / Banco Real & Marcenaria & fev/07 \\
\hline Valor total em instalações & 3.600 & &
\end{tabular}

Fonte: Arquivo HABIS/IAU/USP, 2008.

\subsubsection{Aumento do estoque de matéria-prima (madeira de plantios florestais)}

Laverde (2007) sobre a dinâmica de comercialização de madeira de plantios florestais da região de Itapeva/SP cita estudos de 2004 que revelam grandes dificuldades relacionadas ao fornecimento de madeira adequada para esquadrias. Dentre os fatores que interferem na qualidade da madeira nesta região foram citadas: as condições precárias (tanto tecnológica quanto organizacional) das serrarias, a baixa oferta de matéria-prima (toras acima de $\varnothing$ $25 \mathrm{~cm}$ ), baixa capacitação da mão-de-obra das serrarias, tendência ao mercado externo, dentre outros. Agravantes desta situação são os interesses dos grandes detentores de florestas da região: as indústrias papeleiras e de celulose. O manejo da floresta destas empresas não é adequado ao fornecimento de madeira para fins nobres (móveis e esquadrias). Estas florestas são voltadas ao mercado externo e utilizam manejo mecanizado em todas as etapas da cadeia não favorecendo a economia local pois, não contratam a força de trabalho local e ainda, enfraquecem as pequenas serrarias. Segundo Laverde (2007) este cenário madeireiro local dificulta a produção de esquadrias para habitações de interesse social quando produzidas em um empreendimento autogestionário. A autora levanta como motivos que levaram a esta reflexão:

- a participação majoritária dos assessores no processo de compra de madeira devido ao acúmulo de conhecimento necessário para a negociação e escolha da madeira;

- as possibilidades de parcerias para fornecimento de madeira a preço de custo ou doações reduzidas, pois as árvores plantadas estão sob posse do setor celulósico-papeleiro, sendo que 
apenas 10\% das plantações estão sob domínio do setor público, reduzindo as possibilidades de parcerias com estes órgãos, pois o volume de madeira não atenderia a demanda;

- maior parte das madeiras disponíveis na região não apresentam as características apropriadas para a produção de esquadrias;

- a oferta de madeira é descontinuada, ou seja, não há garantias quanto ao fornecimento de madeira, criando cenário de incerteza sobre a disponilidade de matéria-prima para produção dos componentes.

Ilustra este quadro de instabilidade para a produção de esquadrias de madeira na marcenaria e eforça a necessidade de garantir um estoque de madeira os estudos realizados por Castanho Filho (2008). A figura 30 mostra de modo evidente a relação entre aumento da demanda e elevação das cotações dos produtos florestais oriundos de florestas plantadas ocorrida nos últimos 16 anos. Demonstra também, que em 2004, época de aquisição das madeiras para produção das janelas de Pirituba, a cotação da madeira teve um aumento de aproximadamente 20\% em relação a 2003 e em 2007, época de aquisição das madeiras para produção das janelas do Sepé, a cotação da madeira teve um aumento de aproximadamente $40 \%$ em relação a 2004. Esta tendência de crescimento das cotações da madeira fragiliza os pequenos produtores e dificulta a instalação de cadeias produtivas voltadas a fabricação de móveis e esquadrias.

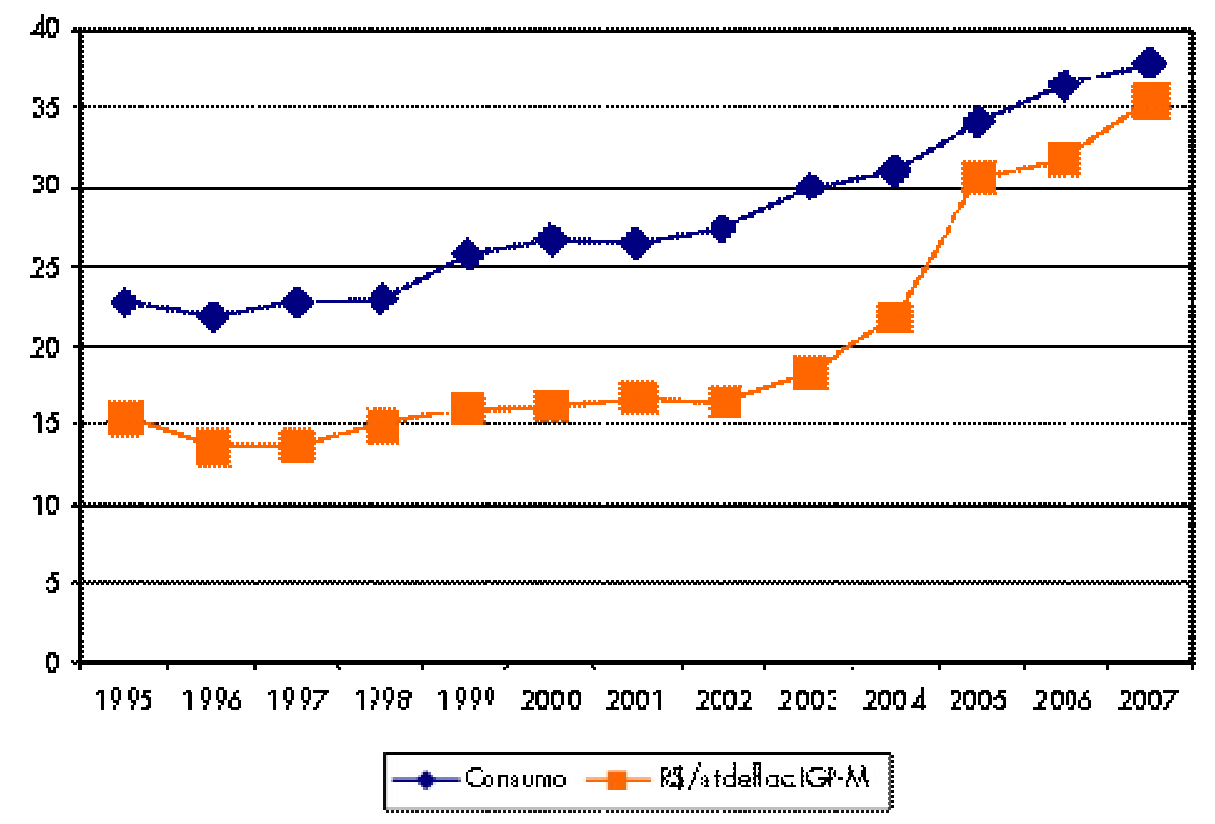

Figura 30 Evolução do Consumo Aparente e dos Preços de Madeira, Estado de São Paulo, 1995 a 2007.

Fonte: CASTANHO FILHO, E.P. (2008) 
Os dados coletados pelas autoras Laverde (2007) e Leite (2009) reforçam a necessidade de composição de um estoque de madeira pela Marcenaria Coletiva Autogestionária. As autoras descreveram os processos de aquisição, secagem, controle de qualidade, estocagem e seleção para processamento da madeira utilizada tanto na fabricação das janelas de Pirituba quanto das janelas do Sepé. Os dois processos identificaram as dificuldades em se conseguir madeira nas condições adequadas (umidade de uso entre 12\% e 15\%, baixa tolerância para defeitos como empenamentos, tortuosidades, bolsas de resina, nós, rachaduras e outros, manejo adequado na floresta de toras com mais de 25 anos e diâmetro de toras maiores que $30 \mathrm{~cm}$, baixos índices de contração, etc.). Para a produção de Pirituba adotaram-se estratégias de doação e compras de madeira sendo, a madeira com melhor aproveitamento segundo Laverde (2007) adquirida por meio de compra pelo valor de 365 reais $/ \mathrm{m}^{3}$ (contando com a parceria da serraria que cobrou o preço de custo). Para a produção do Sepé, a partir da experiência de Pirituba, a estratégia adotada, segundo Leite (2009) foi a de aquisição de madeira por meio da compra pelo valor de 700 reias $/ \mathrm{m}^{3}$. De 2004 quando foi comprada a madeira para a produção das janelas de Pirituba a 2007 quando foi comprada a madeira para a produção das janelas do Sepé houve um aumento de um pouco menos de $100 \%$ do valor da madeira serrada em três anos.

Neste sentido, a estratégia de composição de um estoque mínimo de madeira foi exposto pelos assessores ao grupo da marcenaria. As primeiras tentativas de composição deste estoque vieram com a participação e contemplação de projetos de captação de recursos. Em 2006, com o projeto "Produção de Conhecimento Simultaneamente a Incubação de Empreendimentos Solidários no Assentamento Rural Pirituba II, Itapeva / SP - Região de Consad", fontes de recurso FINEP/RTS, foi possível adquirir oito $\mathrm{m}^{3}$ de madeira de eucalipto cuja proposta era manter como estoque para atender a demandas de encomendas. No entanto, este estoque de madeira foi utilizado para suprir a demanda das próprias marceneiras em mobiliar suas casas.

Sobre a participação das marceneiras na aquisição das madeiras cabe salientar a participação crescente das marceneiras no planejamento para escolha do fornecedor, monitoramento das características da madeira a ser fornecida e controle de recebimento. De 2004 a 2006, durante a produção das janelas de Pirituba, o planejamento desta etapa foi realizado predominantemente pela assessoria, contantando com a participação dos assentados apenas na fase de estocagem da madeira e, em uma das oportunidades, com a participação no corte da árvore na floresta. A hipótese dos assessores era a de que esta etapa de planejamento para aquisição da madeira determinava a qualidade do produto final e que há competências e habilidades necessárias 
para cumprimento desta etapa que os assentados não dispunham naquele momento. De 2007 a 2010 as marceneiras passaram a participar do processo de compra das madeiras quando não 0 faziam sem a participação dos assessores. É evidente o aumento da compreensão das marceneiras quanto a importância desta etapa na atividade produtiva e seu impacto nos resultados esperados.

Estratégias para aumentar a estabilidade de acesso à madeira de qualidade foram pouco exploradas. Uma iniciativa promissora no sentido de prover 0 assentamento de madeira para variados fins, dentre estes a produção de móveis e janelas, foi impulsionada pelo Departamento de Ciências Florestais da ESALQ/USP que iniciou em 1995 o projeto TUME (Teste de Uso Múltiplo de Eucalyptus) com a finalidade de proporcionar ao agricultor e seus vizinhos conhecimentos e técnicas necessárias para a plantação de diferentes "eucaliptos" (STAPE, 2005). O TUME foi implementado em apenas um dos lotes existentes no assentamento. A proposta construída foi de efetuar o plantio de pelo menos nove espécies diferentes de eucalipto em uma área de um hectare de difícil plantio de alimentos. A proposta foi pouco aceita. Há várias hipóteses explicativas uma delas pode ser 0 assédio constante pelas grandes reflorestadoras que cooptam os assentados para arrendar suas térreas e plantar a madeira para a grande empresa que os paga em dinheiro. 0 retorno financeiro do TUME só viria após quatro anos de plantio quando poderia retirar a madeira para carvão ou cercamento.

Desta forma o estoque de madeira é uma das estratégias de ampliação da autogestão da Marcenaria Coletiva de Mulheres que merece maior atenção já que não se implementou efetivamente.

\subsubsection{Constituição de um fundo coletivo}

As relações sociais de produção desenvolvidas nos empreendimentos econômicos solidários são distintas da forma assalariada. Muito embora, também aqui, os formatos jurídicos e os graus de inovação no conteúdo das relações sejam variáveis e sujeitos à reversão, as práticas de autogestão e cooperação dão a esses empreendimentos uma natureza singular, pois modificam 0 princípio e a finalidade da extração do trabalho excedente. Assim, aquelas práticas: a) funcionam com base na propriedade social dos meios de produção, vedando a apropriação individual desses meios ou sua alienação particular; b) o controle do empreendimento e 0 poder de decisão pertencem à sociedade de trabalhadores, em regime de paridade de direitos; c) a gestão do empreendimento está presa à comunidade de trabalho, que organiza o processo produtivo, opera as estratégias econômicas e dispõe sobre o destino do excedente produzido (VERANO, 2001). Em suma, há uma unidade entre a posse e o uso dos meios de produção. 
Segundo Gonçalves (2003) os EES devem prever a existência de mecanismos democráticos de gestão de questões como: política de remuneração, política disciplinar, política de saúde e previdência, formas de organização da produção e destinação solidária dos resultados. No entanto, não há regulação legal para todas as categorias de trabalho associado que propicie condições para garantir o funcionamento destes mecanismos.

Diante deste déficit relacionado a deficiência do marco legal da economia solidária os EES, principalmente os informais, lançam mão de mecanismos internos de garantia dos direitos do trabalhador chamados fundos. A semelhança dos fundos obrigatórios das cooperativas ${ }^{21}$, os fundos criados pelos EESs informais são reservas em dinheiro, constituídas com a contribuição de todos os associados, que visam garantir o desenvolvimento das atividades do empreendimento e conceder aos associados alguns "direitos trabalhistas", tais como férias e gratificação natalina. Mas, diferente dos fundos de uma cooperativa, os EESs informais ou formalizados como associações não são obrigados a depositar uma porcentagem pré-determinada de suas sobras (no caso das cooperativas a lei 5.764/1971 determina a constituição de um fundo obrigatório com 10\% das sobras líquidas e para o fundo de assistência técnica, educacional e social é de 5\% das sobras líquidas). No caso da Marcenaria Coletiva de Mulheres o fundo é constituído por $10 \%$ de toda entrada e de aportes feitos por colaboradores.

Na histórica da marcenaria seu fundo foi utilizado de duas formas: para suprir uma necessidade eminente e outra para garantir os direitos da trabalhadora. A primeira forma de utilização do fundo depõe contra sua finalidade. Diante dos recursos escassos e dificuldade de comercialização de seus produtos, os membros da marcenaria muitas vezes se viram obrigados a lançar mão do fundo para: cobrir os custos de energia elétrica, insumos e compra de madeira. No entanto, apesar da prática habitual era o uso para fins inadequados do fundo, em uma única oportunidade as marceneiras puderam compreender a necessidade de sua constituição. Uma das marceneiras no caminho par a marcenaria teve sua perna fraturada. Foi unânime no grupo das marceneiras a necessidade de cobrir os dias os quais a trabalhadora ficaria parada por consequência do acidente de trabalho.

${ }^{21}$ A Lei 5.764/1971, que define a política nacional do cooperativismo no Brasil, confirma expressamente a obrigação da constituição de fundos legais: Fundo de Reserva e Fates - Fundo de Assistência Técnica, Educacional e Social. 
Desta forma, é possível tecer as seguintes hipóteses explicativas sobre 0 fundo coletivo e sua relação com a autogestão:

a) De maneira geral, o fundo coletivo em EESs informais garante a autonomia sobre os meios de produção uma vez que podem ser utilizados para garantir 0 acesso a estes meios;

b) No caso específico da marcenaria, há dificuldades crescentes em manter o fundo coletivo, sua utilização está relacionado a correção de distorções relacionadas a baixa renda, a sua própria dificuldades de gerenciamento e de comercialização;

c) Após a utilização do fundo para seu fim específico é possível inferir que os membros da marcenaria compreenderam a necessidade de sua manutenção.

\subsubsection{Participação democrática nos processos decisórios}

As normas de funcionamento do grupo aparecem na história de consolidação do mesmo. Primeiramente aconteceram organizações não formalizadas na tentativa de estabelecer os mutirões. Porém, nas formações iniciais buscou-se estabelecer algumas normas através do Regimento Interno da marcenaria, que foi discutido coletivamente.

Nem todas as pessoas que fizeram parte dessa construção se mantiveram no grupo, dessa forma, a proposta é revisar esse regimento com os critérios estabelecidos na construção coletiva com os novos integrantes do grupo. Outra norma de funcionamento do grupo diz respeito à frequência de trabalho. Essa sempre foi uma preocupação. Desde o início as presenças foram controladas em um caderno pelo marceneiro instrutor, sendo que, em suas anotações, coloca a data, o período de trabalho e a função exercida no dia. O que sempre controlou as faltas foram as relações de mutirão com o canteiro, pois essa era a forma estabelecida com o grupo de mutirão do assentamento denominado Grupão: cada cinco dias trabalhados na marcenaria corresponde a um dia com cinco pessoas na casa de uma marceneira. Atualmente, na fase das encomendas, o grupo continua marcando as faltas e faz a divisão da retirada controlando os dias de trabalho de cada uma.

As reuniões ocorrem no dia-a-dia do trabalho e os problemas corriqueiros são tratados no mesmo momento. Já os problemas advindos de conflitos interpessoais são tratados em reuniões com a presença da assessoria.

O grupo apresentou desenvolvimento no que se refere à organização. Inicialmente realizava apenas reuniões com a equipe da Universidade, atualmente o grupo se organiza sozinho 
para encaminhar as necessidades diárias, construiu um regimento interno e administra um fundo coletivo. Contudo, fica a questão de como evoluirá esse aspecto, quando o empreendimento cortar seus laços com a universidade.

\subsubsection{Grau de identidade do grupo entorno dos valores de cooperação e solidariedade no trabalho}

De modo geral, o fato da marcenaria ter iniciado suas atividades no âmbito de um processo de trocas entre os assentados ao longo da construção das próprias casas já garante ao grupo da marcenaria um grau elevado de identidade do grupo entorno dos valores de cooperação e solidariedade. Ao adotarmos a premissa de que as variáveis que interferem no grau de autogestão dos EESs também são regidas por processos educativos, podemos salientar que a solidariedade e a cooperação são valores construídos ao longo do desenvolvimento do empreendimento. Desta maneira, faz-se necessário averiguar ao longo do desenvolvimento da Marcenaria Coletiva de Mulheres quais outros fatores podem interferir na evolução destes valores.

As marceneiras em várias oportunidades confirmaram sua relação com a solidariedade ao afirmarem sua estratégia de comercialização ser preferencialmente com os assentados e não em lojas nos centros urbanos. A justificativa se pautava pelo acesso de seus pares a seus produtos pois, de outra maneira teriam dificuldade de adquirir produto de qualidade semelhante fora deste circuito.

No que tange o funcionamento interno da marcenaria, estudos evidenciam a necessidade de uma reflexão sobre as diversas competências a serem valorizadas no empreendimento. Verifica-se que é uma questão delicada: lidar com diferenças e equidades e mais ainda, poder discutir essas questões sem ameaçar o empreendimento. A dificuldade de equilibrar, por meio de normas construídas no coletivo, os interesses individuais e coletivos, sem que haja perdas de nenhuma das partes envolvidas, é apontada nas sistematizações feitas pela assessoria de incubação da marcenaria, como ponto crucial para o entendimento da grande maioria dos conflitos interpessoais dentro da marcenaria.

Em resposta às demandas advindas destes conflitos algumas ferramentas são geradas pela equipe assessora e adaptadas à realidade do grupo, são exemplos: planilha de atores, mapa cognitivo e mapa dos sonhos. O objetivo buscado nestas intervenções é demonstrar se as ações do coletivo convergem ou não para os objetivos do próprio coletivo e de cada indivíduo e depois explicitar as propostas e os limites de cada um dos indivíduos e tirar os encaminhamentos. Verifica-se aqui que esta dinâmica de comunicação efetiva com o grupo, por meio de 
experimentação de dinâmicas variadas de moderação de reuniões, de uso de linguagem verbal adaptada, materiais ilustrativos, etc., tornasse uma estratégia que aumenta em certa medida, os conhecimentos sobre a realidade e, neste sentido, essa grande oportunidade de grandes interações permite, sobre alguns aspectos, uma maior interação.

"Para que a autogestão se realize é preciso que todos os sócios se informem do que ocorre na organização e as alternativas disponíveis para a resolução de cada problema" (SINGER, 2002, p.19). Na autogestão a comunicação tem que ser efetiva, pois além de estarem cumprindo a sua função todos precisam saber das informações da cooperativa, pois fazem parte de todos os processos e decisões do empreendimento. Uma vez que todos se preocupem com os problemas gerais da organização ela pode funcionar democraticamente. "O maior inimigo da autogestão é o desinteresse dos sócios, sua recusa ao esforço adicional que a prática democrática exige" (SINGER, 2002, p. 19).

Entende-se então, que a principal forma que colabora na resolução de conflitos, mais do que a criação de normas formais, é a construção de espaços para o diálogo igualitário, sejam eles nas reuniões, nos espaços informais, nas conversas individuais, confraternizações ou outros espaços e esta construção depende, fundamentalmente, da relação não hierárquica construída entre os pesquisadores / assessores e os grupos.

Desta forma, é possível identificar que o grau de identidade do grupo entorno dos valores da solidariedade e cooperação no trabalho não está relacionado apenas ao reconhecimento do papel do indivíduo como integrante de um projeto comum e pelo maior envolvimento e uma maior participação dos integrantes no processo de gestão e produção do empreendimento (CRUZ, 2006) mas está relacionado, também, a participação do EES como entidade nas interações com a comunidade em que se insere ou grupo social que se identifica. Por fim, as hipóteses verificadas no exame desta sub-classe de variáveis (solidariedade e cooperação) são:

a) Graus crescentes de motivação entorno dos valores da solidariedade e cooperação no grupo;

b) Facilitar o acesso de seus produtos por assentados e a tendência a trocas não monetárias foram as estratégias mais utilizadas de comercialização e aproximam o grupo aos valores da solidariedade e cooperação;

c) A dependência da intervenção dos assessores nas questões conflituosas no âmbito do empreendimento diminui o grau de identidade do grupo entorno dos valores da solidariedade e cooperação no trabalho. 


\subsection{Exame do processo de adequação sociotécnica}

A ação na realidade e a posterior análise da literatura relacionada a produção de conhecimento e tecnologia indicaram variáveis que interferem no processo de adequação sociotécnica. As variáveis identificadas estão relacionadas a: a) parcerias, agentes e papéis desempenhados; b) equipamentos e dispositivos; c) capacidades adquiridas pelas marceneiras e d) projeto e fabricação de produtos.

O exame dessas subclasses de variáveis possibilitaram a verificação de hipóteses de pesquisa relacionadas a adequação sociotécnica. A figura 31 revela a síntese do processo de adequação sociotécnica na fabricação de janelas na marcenaria. Os tópicos seguintes a síntese apresentada trarão os exames detalhados de cada subclasse de variáveis estudada. 


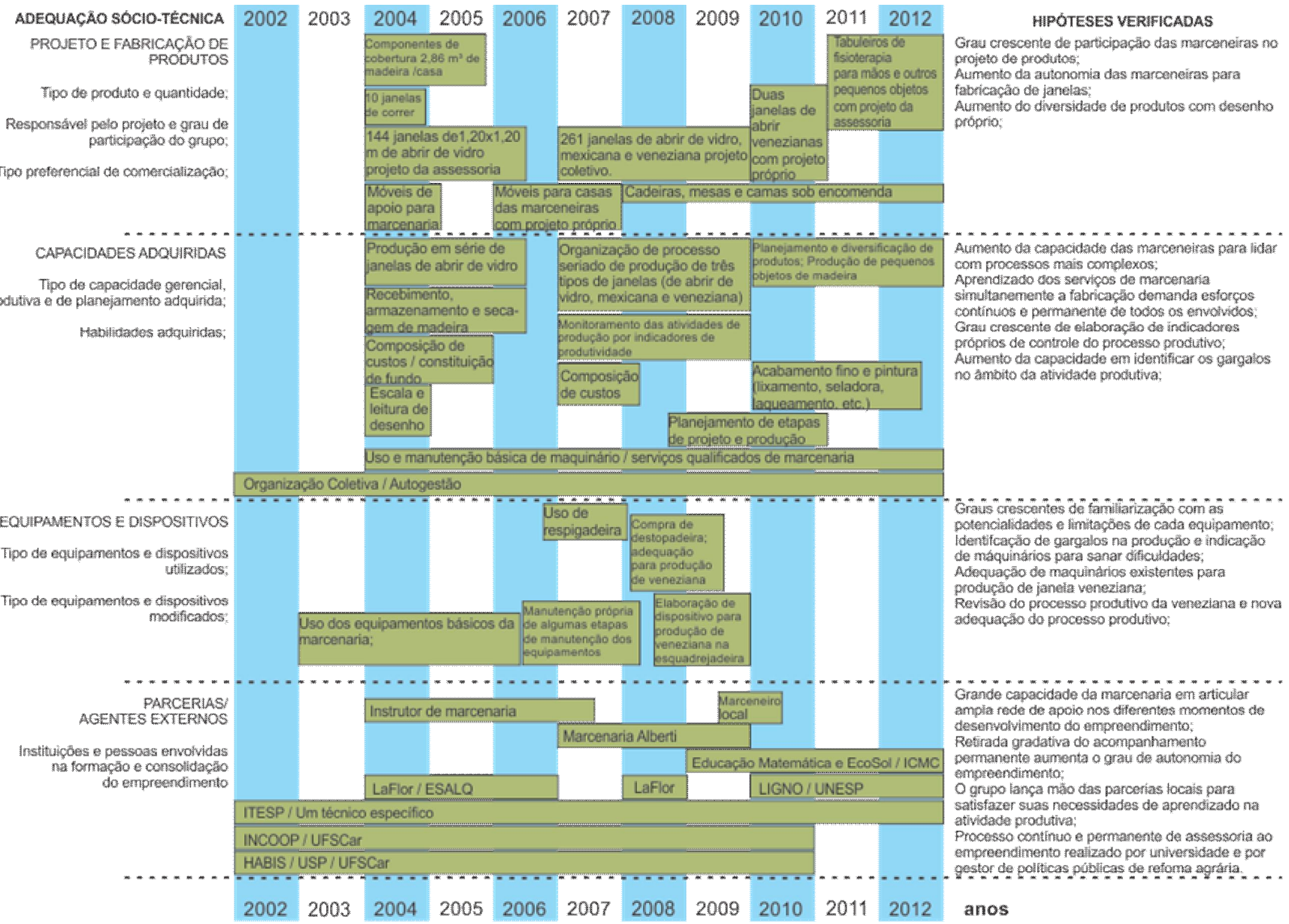

Figura 31 Linha do tempo contendo a síntese do exame do processo de adequação sociotécnica da Marcenaria Coletiva de Mulheres contendo as variáveis identificadas e as hipóteses verificadas. 


\subsubsection{Parcerias, agentes externos e papéis desempenhados no processo de adequação sociotécnica}

O processo de formação da marcenaria contou com a participação de várias instituições públicas e privadas. Os parceiros desempenhavam diferentes papéis neste processo: dentro da cadeia produtiva, seja na capacitação das marceneiras para a produção ou gestão seja no fornecimento de matéria-prima; na mediação de políitcas públicas seja como facilitador do acesso as moradias seja no cumprimento das funções como gestor. Mostrou-se de grande importância para o processo produtivo as parcerias realizadas com pessoas. Um exemplo é a parceria com um marceneiro local que determinou o sucesso da produção seriada de venezianas na marcenaria coletiva e o exemplo marcante foi a disposição de acompanhamento cotidiano por um marceneiro instrutor durante o processo inicial de formação da marcenaria.

A manutenção de uma equipe de incubação contínua e permanente composta por professores universitários (coordenadores gerais), profissionais formados (coordenadores executivos de incubação) e alunos de graduação promoveu as mediações necessárias e possíveis ao longo dos momentos da marcenaria, seja, disponibilizando técnicas de monitoramento de processos, seja, disponibilizando tecnologia para produção de janelas.

Vale destacar, dois aspectos importantes nesta estratégia: i) 0 empreendimento estudado busca por meio das trocas de conhecimento e estreitamento das relações com laboratórios associados aumentar sua eficiência nos termos abordados por Gaiger (2003) a partir da adoção de: a) estratégias e ferramentas de monitoramento da produção, b) de estudos de racionalização da produção em escala e c) de composição dos custos e preços; ii) no acesso ao conhecimento para desenvolvimento de produtos: o desenvolvimento de alternativas de componentes para habitação pelos laboratórios e grupos de pesquisa, a apresentação das técnicas existentes para produção, a análise das necessidades dos usuários e dos limites de produção pela Marcenaria associados a avaliação e revisão contínuas e permanentes do processo em conjunto com as marceneiras geraram produtos viáveis economicamente e tecnicamente, conformando um ciclo de desenvolvimento de produto adequado sócio e tecnicamente pois, envolve os empreendimentos econômicos solidários, laboratórios e instituições de ensino superior e usuários em um mesmo processo onde os resultados serão compartilhados em prol da melhoria de qualidade de vida de todos os envolvidos. 


\subsubsection{Equipamentos e dispositivos}

É possível notar que a marcenaria, apesar de contar com poucos recursos financeiros, obteve acesso às máquinas, ferramentas e instalações necessárias para iniciar e desenvolver suas atividades em grande parte em função das parcerias construídas.

O avanço da adequação sociotécnica nesta categoria de análise é notável uma vez que é possível identificar quatro momentos distintos mas que se complementam: primeiro momento a marcenaria utiliza as máquinas ofertadas pelos parceiros para execução da atividade produtiva; segundo momento as marceneiras constatam dificuldades no manuseio destes equipamentos devido a ausência de manutenção das máquinas e passa a monitorar e realizar manutenções por conta própria; terceiro momento as marceneiras identificam limites nos usos das máquinas existentes na marcenaria e buscam alternativas para adquirir máquinas mais adequadas a produção de janelas; e quarto momento as marceneiras, com apoio de marceneiro local, adéquam as máquinas existentes para facilitar a fabricação de janelas. Estes quatro momentos denotam:

- Uma primeira fase de transferência de conhecimento e tecnologia pelos assessores ao grupo da marcenaria;

- Uma segunda fase de apropriação pelas marceneiras da tecnologia por meio da aquisição de competências suficientes para controle e identificação dos limites das máquinas existentes;

- Uma terceira fase de adequação do maquinário com apoio de agente local contatado pelo próprio grupo para auxílio em etapa específica da fabricação de janelas.

\subsubsection{Capacidades adquiridas pelas marceneiras}

Foi possível constatar a capacitação contínua e permanente do grupo da marcenaria. Esta capacitação ocorreu predominantemente simultaneamente a atividade produtiva. Esta estratégia se mostrou adequada por alguns motivos: adequação aos recursos existentes (recursos para capacitação não existiam para tanto contou-se constantemente com a atuação de parcerias em estratégias pontuais de capacitação externas ao processo produtivo; os recursos disponíveis eram escassos nos processos de fabricação de janelas descritos e suas fontes advinham dos recursos para construção ou da pesquisa) e ao tempo disponível para capacitação (considerando as relações existentes entre o tempo do canteiro de obra, o tempo da pesquisa e 0 tempo do financiamento). Esta estratégia foi viabilizada em seu início pela existência de um marceneiro instrutor com motivação e disponibilidade para orientar em tempo integral as marceneiras e, evidentemente, pela disposição e força destas em enfrentar este desafio em 
conjunto com a assessoria. Foram verificados alguns pontos positivos deste tipo de atuação: 0 enfrentamento das dificuldades e desafios no cotidiano do trabalho orientando de maneira objetiva a atuação de todos os envolvidos e a efetivação de um aprendizado coeso e completo. Foram dificuldades e limites relacionados à esta estratégia de capacitação: alta dependência do grupo da marcenaria da presença dos assessores ocasionando dificuldades em aprendizado das etapas de planejamento e projeto dos produtos e da produção, o tempo necessário para 0 aprendizado em todas as etapas do processo produtivo é demasiado grande quando tratamos de um empreendimento de mulheres, agricultoras e avós e a assessoria deve ser permanente e contínua. Neste último fator concorre a necessidade de recursos para manutenção da equipe assessora. Como alternativa para superação desta dificuldade foram construídas redes locais de apoio ao empreendimento já que a assessoria da INCOOP, do HABIS e do LaFlor se encontram a mais de $200 \mathrm{~km}$ da sede da marcenaria coletiva.

Como elementos que indicam um avanço da marcenaria em relação as competências e habilidades adquiridas podemos citar:

a) Criação de ferramentas de gestão e monitoramento da produção próprios. Esses marceneiros, mulheres e jovens, trabalham, em média, 6 horas por dia, com intervalo de 1 hora de almoço e descanso, das tarefas da marcenaria, aos sábados e domingos. Para a remuneração, criou-se uma regra baseada na presença e faltas de cada um, ou seja, recebe-se pelos dias trabalhados, de acordo com cada encomenda. Esse controle é feito no caderno de atividades da marcenaria, aonde as marceneiras registram as pessoas presentes e ausentes em cada dia, as horas trabalhadas e as atividades desenvolvidas. Além disso, cada marceneira tem o seu próprio caderno de atividades, como forma de verificar possíveis erros ou anotações erradas no caderno geral da marcenaria;

b) Controle sobre os indicadores de qualidade da madeira como umidade de equilíbrio da madeira, quantidade de efeitos toleráveis, número máximo de peças com defeitos, etc.;

c) Conquista de habilidades referentes ao planejamento da produção como elaboração do romaneio, "receita" para organização e divisão do trabalho;

d) Conquista de habilidades relacionadas a etapa de desenho e projeto como elaboração de projeto próprio de veneziana a partir do acúmulo ao longo de todo o processo.

A figura 32 traz a síntese das habilidades adquiridas pelo conjunto das marceneiras e jovens que participaram do grupo. É possível notar uma evolução no caso da Marcenaria Coletiva 
de Mulheres no sentido da produção própria de tecnologia para enfrentamento dos desafios da fabricação em série de janelas.

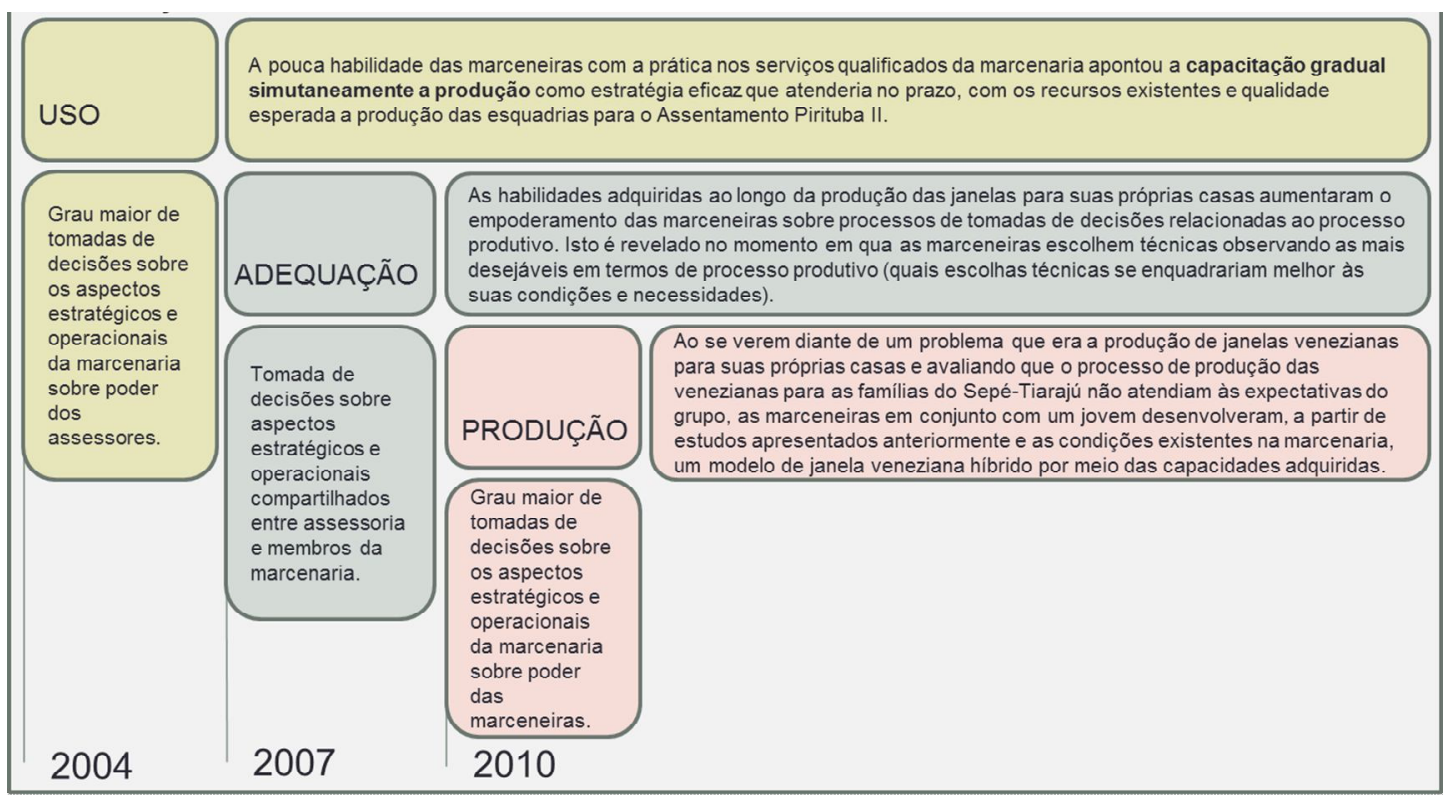

Figura 32 Síntese das habilidades e capacidades adquiridas pelas marceneiras ao longo dos momentos do processo de produção das janelas.

\subsubsection{Projeto e fabricação de produtos}

Segundo Melhado et al (2005), o processo do projeto pode ser dividido nas seguintes etapas: 1) idealização do projeto; 2) desenvolvimento do produto; 3) formalização do produto; 4) detalhamento do produto; 5) planejamento para projeto do produto; e 6) execução e entrega final. Nessas etapas são desenvolvidos os projetos do produto, projetos para produção e projetos da produção.

O exame do processo de produção das janelas indicou que:

a) Há um grau crescente de participação das marceneiras na idealização do projeto e no detalhamento do projeto;

b) O avanço das marceneiras em participar domo protagonista nos processos de projeto garantiu um aumento da autonomia das marceneiras para fabricação de janelas;

c) Como consequência do aumento da autonomia do grupo foi constatado um aumento do diversidade de produtos com desenho próprio. 


\section{CONCLUSÕES E SUGESTÕES PARA TRABALHOS FUTUROS}

É importante lembrar que a marcenaria estudada foi formada como meio de resistência dos assentados e assentadas na efeitivação da ocupação da terra. A marcenaria possibilitou a construção das moradias de qualidade no assentamento rural Pirituiba II e facilitou 0 acesso das famílias do assentamento Sepé-Tiarajú a janelas de madeira quando o convencional seria janelas metálicas que possivelmente seriam substituídas brevemente. A marcenaria possibilitou o aperfeiçoamento da convivência humana nas atividades grupais e nas interações com agentes externos promovendo assim, novas aprendizagens mesmo em um meio de recursos escassos.

O exame da produção de janelas na Marcenaria Coletiva de Mulheres revelou que, em escalas e graus diversos, vários elementos sociais e técnicos da autogestão estão presentes no empreendimento indicando perspectivas e possiveis tendências de evolução.

Com relação aos fatores que favoreceram a produção autogestionária de janelas podemos identificar:

a) O grupo ter se organizado entorno dos valores da solidariedade e da cooperação desde sua gênese;

b) O grupo ser constituído por um número reduzido de associados;

c) A equipe de incubação ter se afastado gradualmente do papel de definidor das estratégias de produção do grupo da marcenaria;

d) A conquista das mulheres marceneiras de uma posição social diferente de sua posição tradicional dentro do lar aumentanto, assim, sua auto-estima e sua autoconfiança, alavancando o empreendimento a um status de conquista no assentamento revelando a importância de adquirirem novas habilidades;

e) As parcerias com grupos de pesquisa, laboratórios e empresas da cadeia produtiva da madeira possibilitaram o alcance de graus crescentes de autogestão no empreendimento, em especial, as parcerias que ocorreram com instituições e pessoas sediados a um raio de no máximo $30 \mathrm{~km}$ da sede do empreendimento;

Com relação aos fatores que dificultaram a produção autogestionária de janelas identificamos:

a) A dificuldade de manutenção de um fundo coletivo; 
b) A dependência da equipe assessora para processamento de conflitos intragrupo e interpessoais;

c) A deficiência da cadeia produtiva da madeira em fornecer matéria-prima de qualidade a preços justos;

d) A deficiência dos financiamentos a EESs que, quando existentes dificultam 0 atendimento às demandas e necessidades dos empreendimentos (já que muitas vezes não facilitam a compra de matéria prima, não disponibilizam capital inicial ou não possibilitam a melhoria da infraestrutura); possuem tempo diferente do tempo da realidade dos empreendimentos.

Do ponto de vista metodológico, com o intuito de perceber tendências que permitissem examinar a marcenaria como autogestionária, optou-se pela adoção de dois níveis de análise para melhor expressar a dimensão da realidade que se pretendia captar: a transição para autogestão e adequação sociotécnica. Cada nível foi detectado, detalhando-se aspectos pertinentes para tornar mais explícito a autogestão como processo educativo engendrado pelas relações entre atores da economia solidária.

As variáveis utilizadas para compor os indicadores das "causas dominantes" foram obtidas a partir da descrição da história do empreendimento, desde o momento de sua constituição e consolidação, até as práticas de organização e estratégia de funcionamento adotados ao longo do processo produtivo das janelas e posteriormente de pequenos objetos de madeira. Tais relatos foram cruciais para permitir a conclusão de que, na origem da constituição da marcenaria, estava a motivação, em um primeiro momento, frente à luta por moradia digna e de qualidade e, em segundo momento, frente à necessidade de geração de renda. Para as marceneiras a conquista a organização do empreendimento materializou-se como a conquista pela geração de uma atividade produtiva que gere renda e que esteja sob o controle de mulheres.

Quanto as possíveis generalizações do caso estudado, seria um equívoco extrair do processo descrito na Marcenaria Coletiva de Mulheres mais do que indicações, algo como uma receita para outros lugares com características comparáveis ainda que o processo de incubação da marcenaria tenha possibilitado a sistematização de conhecimentos para legitimar avanços e equívocos suficientes no assentamento. Mas, é fundamental entrever em dinâmicas como essas, características mais universais e, com todos os cuidados do termo, passíveis de reaplicação nos seus componentes básicos. Podemos destacar como características mais gerais:

a) O exame do processo de produção autogestionária de janelas na Marcenaria de Mulheres, como em outros estudos de caso da mesma natureza ( Cruz, 2006; Cortegoso et al., 2007), 
indica a existência de elementos que se aproximam dos princípios da economia solidária em graus crecentes indicando a autogestão como um processo educativo contínuo e permanente. Desta forma, o processo de transformação se configura como sendo de longo prazo, uma espécie de vir a ser. Como alerta Novaes (2009) um processo que prescinde de pontes entre a realidade que vigora nos empreendimentos e a utopia desejada, tanto pelos trabalhadores quanto pelos assessores da economia solidária;

b) A autogestão examinada no caso aqui estudado se aproxima da autogestão indicada por Singer (2001) uma vez que a autogestão, através das práticas que a envolvem, permitiu educar e transformar gradualmente o comportamento dos sujeitos. Evidencia assim, a autogestão como um processo educativo que expõe os atores envolvidos no processo de incubação, em especial, assessores e membros do empreendimento, a um constante aprendizado;

c) A sistematização do conhecimento disponível e das exigências de tecnologia ratificam a necessidade de sistematizar o conhecimento existente, de desenvolver novas pesquisas investigando aspectos específicos desse conhecimento ou de procedimentos tecnológicos possíveis para transformá-los em tecnologia acessível aos que trabalham com os fenômenos e processos relacionados à assessorar empreendimentos econômicos solidários;

d) A transferência de tecnologia pelas universidades e centros de produção de conhecimento e tecnologia não é incompatível com processos de construção de tecnologias sociais quando inseridas em empreendimentos econômicos solidários na perspectiva da autogestão;

e) Os elementos da vida cotidiana, constituído principalmente pelas atividades domésticas e outros aspectos relacionados a reprodução da vida, não deixaram de fazer parte da vida das mulheres marceneiras, no entanto, é possível corroborar com a afirmação de que a participação da mulher em atividades não agrícolas (que lhe geram acessos a renda individual) contribui para alterar os papéis sociais de gênero, além de favorecer a permanência da mulher no meio rural.

Verificou-se ao longo do exame do estudo de caso a necessidade de avançarmos nas pesquisas relacionadas a ampliação da nossa compreensão sobre os fenômenos que envolvem os empreendimentos econômicos solidários e, em especial os empreendimentos na cadeia produtiva da madeira.

São vários os estudos relacionados ao uso da madeira de plantios florestais para a produção de celulose, energia e embalagens, no entanto, é necessário avançar nos estudos relacionados ao uso mais nobre da madeira de plantios florestais. É necessário, ainda, relacionar estes estudos a viabilização de cadeias produtivas na perspectiva da economia solidária uma vez 
que 0 acesso a madeira, por exemplo, mostrou-se um gargalo para 0 avanço da autogestão aos EES inseridos nesta cadeia. Assim, avançar nos estudos no âmbito da cadeia produtiva da madeira na perspectiva da economia soliodária fortalece a articulação de redes formadas por EESs, que são essenciais à sobrevivência e ao progresso de tais empreendimentos. Parte-se da premissa que isolados, os pequenos empreendimentos, como é o caso da maioria dos EESs, têm poucas chances de se desenvolver. A união em redes e/ou cadeias os fortalece e facilita a superação de suas deficiências.

Faz-se necessário, também, avançar nos estudos sobre os impactos na consolidação de práticas autogestionárias das trocas não monetárias, quando não se envolve 0 dinheiro. No exame do caso da Marcenaria Coletiva Autogestionária as trocas não monetárias auxiliaram na percepção do grau de solidariedade do grupo, no entanto, há alguns indícios de que a não quantificação destas trocas impedem a aferição do grau de equilíbrio e as possíveis distorções neste processo.

Constatou-se ao longo da revisão bibliográfica sobre métodos e modelos de processo de desenvolvimento de produtos (PDP) que é necessário voltar estudos nesta área aos empreendimentos econômicos solidários uma vez que as definições de PDP atuam na perspectiva de "lançar um produto no mercado" posicionando o processo na interface entre a empresa e 0 mercado (TOLEDO, 1993). Fica evidente o auxílio destes processos convencionais na manutenção dos valores e princípios da produção heterônoma, ou seja, os modelos de referência, ferramentas e métodos desenvolvidos são adequados a estrutura de negócios relacionados aos princípios de divisão social e especialização do trabalho e a separação entre atividades de produção e gerenciais. É necessário, portanto, romper a ideia de que o desenvolvimento de produtos deve ser fragmentado entre projetar e executar, e, progressivamente, reverter a proposta de máxima especialização das funções para a máxima eficiência em termos autogestionários independente da complexidade tecnológica. 


\section{REFERÊNCIAS BIBLIOGRÁFICAS}

BERGAMASCO, S. M. P. P. As famílias nos assentamentos rurais: trajetórias e conquistas. In: PRESVELOU, C. et al. Mulher, família e desenvolvimento rural.Santa Maria : Ed. da UFSM, 1996, p.75-92.

BOCAYUVA, P. C. C. Incubadora Tecnológica de Cooperativas Populares /COPPE/UFRJ. In. CAMAROTI, I.; SPINK, P. (orgs.). Redução da Pobreza e Dinâmicas Locais. Rio de Janeiro: editora FGV, 2001.

BOCAYUVA, P. C. C. As metamorfoses do trabalho e da cooperação produtiva: a economia popular e solidária na perspectiva da nova centralidade do trabalho. Rio de Janeiro: FASE. 2007.

BOCAYUVA, P. C. C. Incubação de empreendimentos solidários: elementos para uma abordagem teórico-metodológica da tecnologia de organização do trabalho associado, na perspectiva da construção de políticas públicas para a economia solidária. In BOCAYUVA, P. C. C., VARANDA, A. P. M. (orgs.) Tecnologia social, economia solidária e políticas públicas. - 1.ed. - Rio de Janeiro : FASE : IPPUR, UFRJ, 2009.

BOTOMÉ, S. P. Comportamentos profissionais do psicólogo em um sistema de contingências para a sua aprendizagem. Revista Brasileira de Análise do Comportamento / Brazilian Journal Of Behavior Analysis, 2006, vol. 2, N. 2, 171-191.

BOTOMÉ, S. P. Objetivos de Ensino, necessidades sociais e tecnologia educacional. Tese de Doutorado apresentada ao Instituto de Psicologia da Universidade de São Paulo, 1981.

BRUMER, A. Mulher e desenvolvimento rural. In: PRESVELOU, C. et al. Mulher, família e desenvolvimento rural.Santa Maria : Ed. da UFSM, 1996.

CASTANHO F. E. P. Eucalipto: demanda crescente. 2006. Disponível em <http://www.floresta.org.br/estatisticas/florestar/nr18/01artigo.pdf>.Acesso: 13/10/ 2011.

CASTANHO FILHO, E. P. Consumo aparente, cotações e valor da produção de madeira de florestas plantadas no Estado de São Paulo: uma visão das últimas décadas. Análises e Indicadores do Agronegócio. São Paulo, v. 3, n. 4, abr. 2008. Disponível em: <http://www.iea.sp.gov.br/out/verTexto.php?codTexto=9260>. Acesso em: jan. 2013.

CHANIAL, P. \& LAVILLE, J. L. A economia social e solidária na França. In França Filho et al., Ação pública e economia solidária: uma perspectiva internacional, Porto Alegre, Editora da UFRGS. 2006.

CHERFEM, C. O. Mulheres marceneiras e autogestão na economia solidária : aspectos transformadores e obstáculos a serem transpostos na incubação em assentamento rural. Dissertação (Mestrado). São Carlos: UFSCar, 2009.

CONAES, II. Texto final $2^{\text {a }}$ Conferência Nacional de Economia Solidária. Brasília, 2010.

CORAGGIO, J. L. La Economía social y solidaria como estrategia de desarrollo en el contexto de la integración regional latinoamericana. Reconstrucción de una parte de la ponencia presentada en el 3er Encuentro Latinoamericano de Economía Solidaria y Comercio Justo organizado por RIPESS en Montevideo, 22-24 octubre 2008.

CORTEGOSO, A. L. Atuação junto a cooperativas populares e Análise do Comportamento: trabalho multiprofissional na identificação de lacunas do conhecimento. Trabalho apresentado 
no X Encontro da Associação Brasileira de Psicoterapia e Medicina Comportamental, Campinas, 2004.

CORTEGOSO, A. L. et al. Método de incubação da INCOOP/UFSCar: exame de duas experiências. Revista Proposta: (FASE). Rio de Janeiro, v. 31, n. 112, p. 34-46, abr/jun. 2007.

CORTEGOSO, A. L.; FERRAZ, F. J. ; SHIMBO, I. et al. Evolução na atuação da Incubadora Regional de Cooperativas Populares da UFSCar em relação à economia solidária. In: DAL RI, N. M. (Org.). Trabalho associado, economia solidária e mudança social na América Latina. São Paulo: Cultura Acadêmica, 2010.

CRUZ, A. A diferença na igualdade. A dinâmica econômica da economia solidária em quatro cidades do Mercosul. Tese de doutorado. Campinas. Instituto de Economia, Unicamp, 2006.

CRUZ, F. Género, psicología y desarrollo rural: La construcción de nuevas identidades. Madrid. Ministerio de Agricultura, Pesca y Alimentación, serie ESTUDIOS. 2006.

CUNHA, E. M. P.; ARRUDA, M. V. de; MEDEIROS, Y. (orgs.) Experiências em habitação de interesse social no Brasil. Brasília: Ministério das Cidades, Secretaria Nacional de Habitação, 2007.

DAGNINO, R. P. A tecnologia social e seus desafios. In: LASSANCE, A. E. et al. Tecnologia social: uma estratégia para o desenvolvimento. Rio de Janeiro: Fundação Banco do Brasil, 2004.

DAGNINO, R.; GOMES, E. O processo decisório na universidade pública brasileira: uma visão de análise de política. In: SOBRINHO, D. J.; RISTOFF, I. D. Avaliação e compromisso público. Campinas: Insular. 2003

DUBEUX, A. O papel das Universidades na construção da economia solidária no Brasil. Revista Proposta (FASE), Rio de Janeiro, p. 4 - 15, mar. 2007.

EGAS, L. Análise pluridimensional da sustentabilidade do ciclo de vida de um sistema estrutural de cobertura em madeira de Pinus. Caso Assentamento Rural Pirituba II. Dissertação (Mestrado) - Escola de Engenharia de São Carlos, Universidade de São Paulo, São Carlos, 2008.

FEENBERG, A. Ciencia, tecnología y democracia: distinciones y conexiones. Sci. stud. [online]. 2009.

Teoría crítica de la tecnología. Rev. iberoam. cienc. tecnol. soc. [online]. 2005.

Transforming technology. Oxford, Oxford University Press. 2002.

FERRO, S. Arquitetura e trabalho livre. São Paulo: Cosac Naify. 2006.

FIGUEIREDO, V. Produção social da tecnologia. São Paulo: EPU. 1989.

FRANÇA FILHO, G. C. Teoria e Prática em Economia Solidária: Problemática, Desafios e Vocação. V Workshop Empresa, Empresários e Sociedade: O Mundo Empresarial e a Questão Social. PUC-RS - Porto Alegre, 2006.

FRANÇA FILHO, G. C., JUNIOR, G. S. Economia Solidária e Desenvolvimento Local: uma Contribuição para Redefinição da Noção de Sustentabilidade a partir da Análise de três casos na Bahia. 2010. Disponível em <www.dowbor.org/ar/07genautolocal.doc> acesso em 20 setembro 2011.

GAIGER, L. I. A economia solidária e o projeto de outra mundialização. Dados, Rio de Janeiro, V. 47, n. 4,2004 
GAIGER, L. I. Eficiência Sistêmica. In CATTANI, A. A Outra Economia. Porto Alegre, Veraz Editores, 2003.

GONÇALVES, W. A. 0 marco jurídico da autogestão e economia solidária (relatório final do convênio MTE/ IPEA/ ANPEC - 01/2003). - Brasília: MTE, IPEA, ANPEC, 2005.

GRUPO DE PESQUISA EM HABITAÇÃO E SUSTENTABILIDADE - HABIS. Caderno Verde: incubação de Marcenaria Coletiva Autogestionária simultaneamente à construção de habitação rural. São Carlos. 2009.

GUIMARÃES, S.S. et al. Desenvolvimento de componentes de edificações em fibra de sisalargamassa a serem produzidos de forma autogestionária - PROSISAL. In: BONIN, L.C. e AMORIM, S.R.L. (editores) Inovação Tecnológica na Construção Habitacional. Porto Alegre : ANTAC, 2006. -(Coleção Habitare, v. 6)

HEIDEGGER, M. A questão da técnica. Sci. stud., São Paulo, v. 5, n. 3, Sept. 2007 .

ICAZA, A.M.S.; TIRIBA, L. Economia Popular. In CATTANI, A. A Outra Economia. Porto Alegre, Veraz Editores, 2003.

INO, A., SHIMBO, I., SOUZA, A. J. D. Otimização do processo de fabricação de esquadrias de madeira no centro produtor da região Sul e desenvolvimento de janelas de baixo custo para habitação social. Porto Alegre: Coletânea Habitare ANTAC. 2003.

KRAYCHETE, G. Economia popular solidária: sustentabilidade e transformação social. Texto elaborado para o seminário Economia dos setores populares: sustentabildade e estartégias de formação. Universidade Católica do Salvador. 2006.

LAVERDE, A. Processo produtivo de esquadrias em madeira de eucalipto na marcenaria coletiva do Assentamento rural Pirituba II - Itapeva-SP. Dissertação (Mestrado) - Escola de Engenharia de São Carlos, Uiversidade de São Paulo, São Carlos, 2007.

LASSANCE, A. E. et al. Tecnologia social: uma estratégia para o desenvolvimento. Fundação Banco do Brasil: Rio de Janeiro. 2004.

LECHAT, N. M. P. Economia social, economia solidária, terceiro setor: do que se trata? Civitas - Revista de Ciências Sociais, Porto Alegre, v.2, n.1, 2002.

LEITE, M. P. A economia solidária e o trabalho associativo: teorias e realidades. Rev. bras. Ci. Soc., São Paulo, v. 24, n. 69, Feb. 2009 . Acessado em 26/09/2011.

LEITE, T. M., GAVINO, E. R., INO, A. Análise da produção de 462 janelas de madeira de eucalipto numa marcenaria coletiva com transição para autogestão. Caso múltiplo: marcenaria Marcenaria coletiva (Itapeva-SP) e assentamento Sepé Tiarajú (Serra Azul-SP). In: XI Encontro Brasileiro em Madeira e Estruturas de Madeira, Londrina - Julho, 2008.

LEITE, T. M. ; GAVINO, E. R. ; INO, A . O uso da madeira de plantios florestais para a produção de janelas com folhas mexicanas para habitação social rural. Estudo de caso: Marcenaria coletiva do Assentamento Rural Pirituba II (Itapeva-SP). In: VI Encontro Nacional e IV Encontro Latino-americano sobre Edificações e Comunidades Sustentáveis, 2011, Vitória, ES: ANTAC, 2011.

LEÓN, M. El empoderamiento en la teoria e práctica del feminismo. In: LEÓN, Magdalena (org.). Poder y empoderamiento de las mujeres. Santa Fé de Bogotá, Colômbia: TM Editores, 1997.

LISBOA, A. M. Economia solidária e autogestão: imprecisões e limites. Rev. adm. empres. [online]. 2005, vol.45, n.3, pp. 109-115.

MARCUSE, H. Idéias sobre uma teoria crítica da sociedade. 2ed. Rio de Janeiro: Zahar, 1981. 
MARICONDA, P.R., MOLINA, F. T. Entrevista com Andrew Feenberg. Sci. stud. [online]. 2009.

MELHADO, S. B. (Coord.) Coordenação de projetos de edificações. São Paulo: O Nome da Rosa, 2005;

MEKBEKIAN, G., SOUZA, R. Qualidade na Aquisição de Materiais e Execução de Obras. São Paulo: Pini, 1996.

NOVAES, H. T.; DIAS, R. Contribuições ao Marco Analítico-Conceitual da Tecnologia Social. In: DAGNINO, R. P. (org). Tecnologia social: ferramenta para construir outra sociedade. IG/UNICAMP, Campinas / SP. 2009

NOVAES, H. T. A relação universidade-movimentos sociais na América Latina: habitação popular, agroecologia e fábricas recuperadas. Campinas I SP. Tese apresentada ao Instituto de Geociências como parte dos requisitos para obtenção do título de Doutor em Política Científica e Tecnológica da UNICAMP, 2010.

OAKLEY, P. e CLAYTON, A. Monitoramento e avaliação do empoderamento. São Paulo: Instituto Pólis, 2003.

ROMERO, A. K. B. Análise do processo participativo do grupo da marcenaria na produção de esquadrias de madeira na Marcenaria Coletiva Marcenaria coletiva do Assentamento Rural Pirituba II - Itapeva, SP. 2008. Relatório de Pesquisa (Iniciação Científica) - Departamento de Arquitetura e Urbanismo da Escola de Engenharia de São Carlos, Universidade de São Paulo, 2008.

SALOMON, J.; SAGASTI, F.; SACHS-JEANTET, C. Da tradição à modernidade. Estud. av., São Paulo, v. 7, n. 17, abr. 1993.

SCHIOCHET, V. Institucionalização das políticas públicas de economia solidária: breve trajetória e desafios. In: Mercado de Trabalho: conjuntura e análise. Brasília: MTE/Ipea, n. 40, p. 55-59, agosto de 2009

SHIMBO, L. Z. A Casa é o Pivô: mediações entre o arquiteto, o morador e a habitação rural. 2004. 205p. Dissertação (Mestrado em Arquitetura e Urbanismo) - Escola de Engenharia de São Carlos, Universidade de São Paulo, São Carlos, 2004.

SILVA, C.B.C.; SCHNEIDER, S. Gênero, trabalho rural e pluriatividade. In: SCOTT, Parry; CORDEIRO; Rosineide e MENEZES, Marilda (Org.) Gênero e Geração em Contextos Rurais. Florianópolis/SC, Ed. Mulheres, 2010.

SINGER, P. Autogestão e Socialismo: oito hipóteses sobre a implantação do socialismo via autogestão . In OLIVEIRA, P. S. (org). O Lúdico na cultura solidária. São Paulo, Editora Hucitec: 2001.

Desenvolvimento capitalista e desenvolvimento solidário. Revista de Estudos Avançados, São Paulo, n. 51, 2004.

Uma outra economia é possível: Paul Singer e a Economia Solidária. In: SOUZA, A. R.; CUNHA, G. C.; DAKUZAKU, R. Y. (orgs). São Paulo. Contexto, 2003.

. Economia solidária: um modo de produção e de distribuição. In: SINGER, Paul; SOUZA, André Ricardo et al. Economia solidária no Brasil: a autogestão como resposta ao desemprego. São Paulo: Contexto. 2000.

Introdução à economia solidária. São Paulo: Fundação Perseu Abramo, 2002. 
A recente ressurreição da economia solidária no Brasil. In: SANTOS, B. S. S. et al. Produzir para viver: os caminhos da produção não capitalista. São Paulo: Civilização Brasileira, 2002b.

SOUTO, R. G. Gestão do processo de planejamento da produção em empresas construtoras de edifícios: estudo de caso. Dissertação (Mestrado) - Escola Politécnica da Universidade de São Paulo, São Paulo, 2006.

STAPE, J.L. et al. A extensão florestal através do Projeto TUME. In: Congresso Brasileiro Assistência Técnica e Extensão Rural, 2005.

STROMQUIST, N. La búsqueda del empoderamiento: em qué puede contribuir el campo de la educación. In: LEÓN, Magdalena (org.). Poder y empoderamento de las mujeres. Santa Fé de Bogotá, Colômbia: TM Editores, 1997.

TAJFEL, H. Grupos humanos y categorías sociales. Barcelona: Herder, 1984.

THIOLLENT, M. Metodologia da pesquisa-ação. São Paulo, Cortez. 2002.

THOMAS, H. E. Tecnologias para Inclusão Social e Políticas Públicas na América Latina. In: OTTERLOO, A. et al. Tecnologias Sociais: Caminhos para a sustentabilidade. Brasília/DF: s.n, 25-81. 2009.

TOLEDO, J. C. Gestão da mudança da qualidade de produto. 1993. Tese (Doutorado) - Escola Politécnica, Universidade de São Paulo, São Paulo.

VALLE, I. M. R. A pré-fabricação de dois sistemas de cobertura com madeira de florestas plantadas. Estudos de casos: os assentamentos rurais Pirituba II e Sepá-Tiarajú. 2010. $352 \mathrm{f}$. Tese (Doutorado) - Programa de Pós-graduação em arquitetura e Urbanismo da Escola de Engenharia de São Carlos, Universidade de São Paulo, 2011.

VERANO, L. Economia solidária, uma alternativa ao neo-liberalismo. Santa Maria: Cesma Edições. 2001.

VIERA, M. I. La participación de la mujer en las viviendas rurales por ayuda mutua. Experiências de desarrollo. In: PRESVELOU, C. et al. Mulher, família e desenvolvimento rural.Santa Maria : Ed. da UFSM, 1996, p. 59-74.

YIN, R. K. Estudo de caso: planejamento e métodos. Porto Alegre: Bookman. 2001.

Referências iconográficas

ARQUIVO HABIS, Itapeva - SP, 2007 a 2010. 